
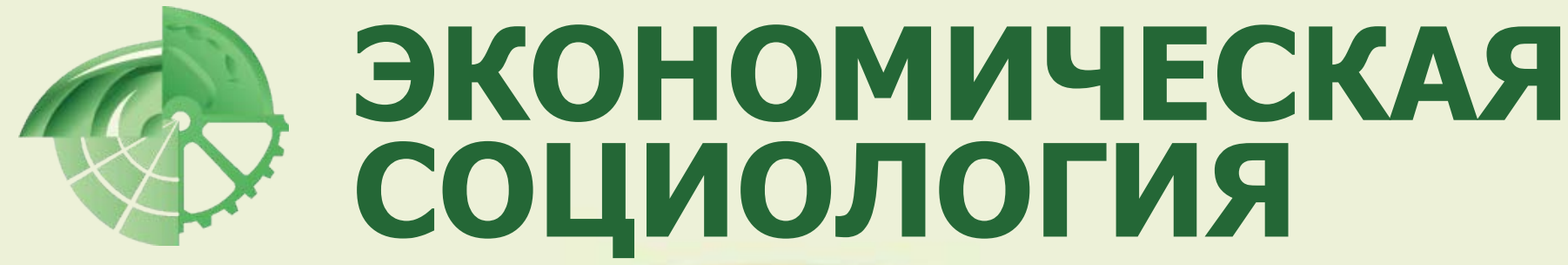

JOURNAL OF ECONOMIC SOCIOLOGY = EKONOMICHESKAYA SOTSIOLOGIYA

Читайте в номере:

Interview with Ivana Pais «Digital Labor and the Sharing Economy»

Рощина я. Стиль жизни в отношении здоровья: имеет ли значение социальное неравенство?

Доббин Ф. Сравнительный и исторический подходы в экономической социологии

Цыплакова Е. Геймификация мотивационная практика или механизм тотального контроля над трудовым процессом? 


\section{Экономическая}

социология

Т. 17. № 3.

Май 2016

Электронный журнал www.ecsoc.msses.ru www.ecsoc.hse.ru

ISSN 1726-3247

\section{Адрес редакции}

101000, Россия,

г. Москва,

ул. Мясницкая,

д. 20, комн. 406

тел.: +7 (495) 628-48-86

email: ecsoc@hse.ru

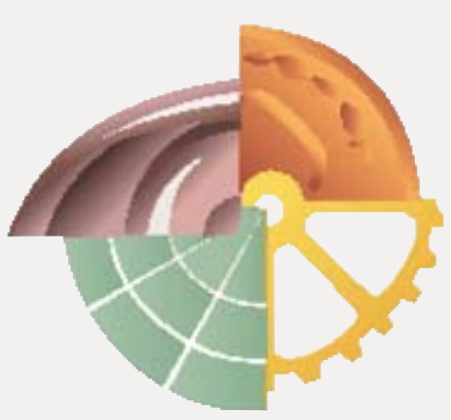

Journal of Economic Sociology

Vol. 17. No 3.

May 2016

Electronic journal www.ecsoc.msses.ru www.ecsoc.hse.ru

ISSN 1726-3247

\section{Contacts}

20 Myasnitskaya street, room 406 101000 Moscow, Russian Federation phone: +7 (495) 628-48-86 email: ecsoc@hse.ru лектронный журнал «Экономическая социология» издаётся с 2000 г. Учредителями являются Национальный исследовательский университет «Высшая школа экономики» (с 2007 г.) и Вадим Валерьевич Радаев (главный редактор).

Цель журнала - утверждать международные стандарты экономико-социологических исследований в России, представлять современные работы российских и зарубежных авторов в области экономической социологии, информировать профессиональное сообщество о новых актуальных публикациях и исследовательских проектах, а также вовлекать в профессиональное сообщество молодых коллег.

Журнал представляет собой специализированное академическое издание. В нём публикуются материалы, отражающие современное состояние экономической социологии и способствующие развитию данной области в её современном понимании. В числе приоритетных тем: теоретические направления экономической социологии, социологические исследования рынков и организаций, социально-экономические стратегии индивидов и домашних хозяйств, неформальная экономика. Также публикуются тексты из смежных дисциплин - неоинституциональной экономической теории, антропологии, экономической психологии и других областей, которые могут представлять интерес для экономсоциологов.

Журнал публикует пять номеров в год: в январе, марте, мае, сентябре и ноябре. Доступ ко всем номерам журнала постоянный, свободный и бесплатный по адресу: http:// www.ecsoc.hse.ru. Каждый номер содержится в едином файле (10-12 п. л. в PDF).

Журнал входит в список ВАК России, индексируется в Российском индексе научного цитирования (РИНЦ) и Emerging Sources Citation Index (ESCI) из Web of Science Core Collection.

Требования к авторам изложены по адресу: http://ecsoc.hse.ru/author_requirements. html

В журнале применяется двойное анонимное рецензирование статей. Все материалы проходят через полный цикл редакторской обработки и корректуры.

Плата с авторов журнала не взимается. Ускоренные сроки публикации статей не предусмотрены.

Tournal of Economic Sociology was established in 2000 as one of the first academic e-journals in Russia. It is funded by the National Research University Higher School of Economics (HSE).

Journal of Economic Sociology promotes international standards of research in economic sociology, presenting new research carried out by Russian and international scholars, introducing new books and research projects, and attracting young scholars into the field.

Journal of Economic Sociology is a specialized academic journal representing the mainstreams of thinking and research in international and Russian economic sociology. Journal of Economic Sociology provides a framework for discussion of the following key issues: major theoretical paradigms in economic sociology, sociology of markets and organizations, social and economic strategies of households, informal economy. Journal of Economic Sociology also welcomes research papers written within neighboring disciplines - new institutional economics, anthropology, economic psychology and related fields, which can be of interest for economic sociologists.

Journal of Economic Sociology has a wide Russian speaking audience, living both in Russia and abroad. Its main target group comprises research scholars, university professors, policy-makers, post-graduates, undergraduates and others who are interested in economic sociology.

Journal of Economic Sociology is indexed by Emerging Sources Citation Index (ESCI) from Web of Science ${ }^{\mathrm{TM}}$ Core Collection.

Journal of Economic Sociology is a bimonthly journal released in five issues (January, March, May, September, and November). Journal of Economic Sociology provides permanent free access to all issues in PDF. Journal of Economic Sociology applies blind peer-review procedures (two referees for each research paper). All papers are subject to editing, proofreading, and professional design layout.

Guidelines for authors: http://ecsoc.hse.ru/author_requirements.html 
Экономическая социология

Т. 17. № 3.

Май 2016

Электронный журнал www.ecsoc.msses.ru www.ecsoc.hse.ru

\section{ISSN 1726-3247}

Журнал выходит пять раз в год:

№ 1 - январь

№ 2 - март

№ 3 - май

№ 4 - сентябрь

№ 5 - ноябрь

Учредители:

- Национальный исследовательский университет «Высшая школа экономики»

- В. В. Радаев

Издаётся с 2000 года

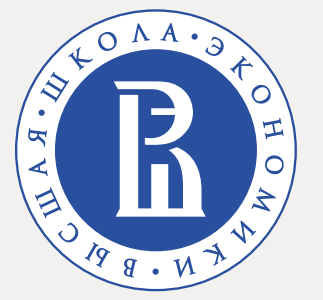

НАЦИОНАЛЬНЫЙ ИССЛЕДОВАТЕЛЬСКИЙ УНИВЕРСИТЕТ

\section{Редакция}

Главный редактор:

Редактор выпуска:

Вёрстка:

Корректор:

Ответственный

секретарь:

Сотрудники

редакции:
Радаев Вадим Валерьевич (НИУ ВШЭ, Россия)

Соколова Татьяна Виленовна (НИУ ВШЭ, Россия)

Мишина Мария Евгеньевна (Россия)

Андрианова Надежда Викторовна (НИУ ВШЭ, Россия)

Котельникова Зоя Владиславовна (НИУ ВШЭ, Россия)

Назарбаева Елена Алексеевна (НИУ ВШЭ, Россия)

Бердышева Елена Сергеевна (НИУ ВШЭ, Россия)

\section{Международный редакционный совет}

Ашвин Сара

(Ashwin, Sarah)

Гербер Тед

(Gerber, Ted)

Гусева Аля (Guseva, Alya)

Зависка Джейн (Zavisca, Jane)

Линднер Петер

(Lindner, Peter)

Сводер Кристофер

(Swader, Christopher)

Якубович Валерий

(Yakubovich, Valery)
Лондонская школа экономики и политических наук

(Великобритания)

Висконсинский университет в Мэдисоне

(США)

Университет Бостона (США)

Университет Аризоны (США)

Университет Франкфурта-на-Майне

им. И. В. Гёте (Германия)

Лундский университет (Швеция)

Бизнес-школа ESSEC (Франция)

\section{Редакционный совет}

\section{Богомолова}

Татьяна Юрьевна

Веселов

Юрий Васильевич

Волков

Вадим Викторович

Гимпельсон

Владимир Ефимович

Лапин

Николай Иванович

Малева

Татьяна Михайловна

Овчарова

Лилия Николаевна

Радаев

Вадим Валерьевич

(главный редактор)

Хахулина

Людмила Александровна

Чепуренко Александр Юльевич

Шанин Теодор

\section{Шкаратан Овсей Ирмович}

Институт экономики и организации промышленного производства СО РАН (Россия)

Санкт-Петербургский государственный университет (Россия)

Европейский университет

в Санкт-Петербурге (Россия)

НИУ ВШЭ (Россия)

Институт философии РАН (Россия)

Институт социального анализа и прогнозирования РАНХиГС (Россия)

НИУ ВШЭ (Россия)

НИУ ВШЭ (Россия)

Аналитический центр Юрия Левады

(Россия)

НИУ ВШЭ (Россия)

Московская Высшая школа социальных и экономических наук (Россия)

НИУ ВШЭ (Россия) 
Journal of

Economic Sociology

Vol. 17. No 3.

May 2016

Electronic journal

www.ecsoc.msses.ru

www.ecsoc.hse.ru

\section{ISSN 1726-3247}

Journal of Economic

Sociology is a bimonthly

journal released in five

issues in annual volume.

No. 1 - January

No. 2 - March

No. 3 - May

No. 4 - September

No. 5 - November

\section{Establishers}

- National Research University Higher

School of Economics

- Vadim Radaev

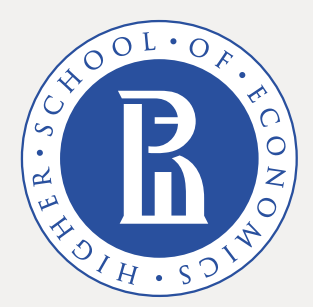

NATIONAL RESEARCH UNIVERSITY

\section{Editors}

Editor-in-Chief:

Editor:

Design and Layout:

Proofreader:

Managing Editor:

Editorial Staff:
Vadim Radaev (HSE, Russia)

Tatyana Sokolova (HSE, Russia)

Maria Mishina (Russia)

Nadezda Andrianova (HSE, Russia)

Zoya Kotelnikova (HSE, Russia)

Elena Nazarbaeva (HSE, Russia)

Elena Berdysheva (HSE, Russia)

\section{International Editorial Council}

Sarah Ashwin

Ted Gerber

Alya Guseva

Peter Lindner

Christopher Swader

Valery Yakubovich

Jane Zavisca

\section{Editorial Council}

Tatyana Bogomolova

\author{
Alexander Chepurenko \\ Vladimir Gimpelson \\ Lyudmila Khakhulina \\ Nikolay Lapin
}

Tatyana Maleva

Lilia Ovcharova

Vadim Radaev (Editor-in-Chief)

Theodor Shanin

Ovsey Shkaratan

Yuriy Veselov

Vadim Volkov
The London School of Economics and Political Science (UK)

University of Wisconsin-Madison (USA)

Boston University (USA)

Goethe University Frankfurt (Germany)

Lund University (Sweden)

ESSEC Business School (France)

The University of Arizona (USA)

Institute of Economics and Industrial

Engineering of the Siberian Branch of Russian Academy of Sciences (Russia)

HSE (Russia)

HSE (Russia)

Yuri Levada Analytical Center (Russia)

Institute of Philosophy of Russian Academy of Sciences (Russia)

Institute of Social Analysis and Forecasting, The Russian Presidential Academy

of National Economy and

Public Administration (Russia)

HSE (Russia)

HSE (Russia)

Moscow School of Social and Economic Sciences (Russia)

HSE (Russia)

Saint Petersburg State University (Russia)

European University at Saint Petersburg (Russia) 


\section{Содержание}

Вступительное слово главного редактора (B. B. Радаев)

9

\section{Тексты на русском языке}

\section{Новые тексты}

Я. М. Рощина

Стиль жизни в отношении здоровья: имеет ли значение социальное неравенство?...

\section{Новые переводы}

Ф. Доббин

Сравнительный и исторический подходы в экономической социологии

\section{Дебютные работы}

Е. О. Цыплакова

Геймификация - мотивационная практика или механизм тотального контроля

над трудовым процессом?

\section{Профессиональные обзоры}

\section{М. М. Сакаева}

Права собственности в фокусе социологических теорий:

через размывание границ к междисциплинарности

\section{Новые книги}

\section{E. А. Мельникова}

Как песни попадают на радио, или Что успех Рианны в чартах

значит для исследователя инноваций

Рецензия на книгу: Rossman G. 2012. Climbing the Charts:

What Radio Airplay Tells Us about the Diffusion of Innovation. Princeton,

NJ: Princeton University Press.

\section{Конференции}

\section{Т. Б. Кусимова}

Образование и социальное неравенство. XVII Апрельская международная научная конференция по проблемам развития экономики и общества,

\section{T. Ю. Ларкина}

Вопросы истории и методологии экономической науки.

XVII Апрельская международная научная конференция

по проблемам развития экономики и общества, 19-22 апреля 2016 г., Москва, Россия. 


\section{Тексты на английском языке}

\section{Interviews}

Digital Labor and the Sharing Economy: An Interview with Ivana Pais

(interviewed by Ivan Pavlyutkin).. 


\section{Contents}

Editor's Foreword (Vadim Radaev). 9

\section{Texts in Russian}

\section{New Texts}

Yana Roshchina

Health-Related Lifestyle: Does Social Inequality Matter?

\section{New Translations}

Frank Dobbin

Comparative and Historical Perspectives in Economic Sociology

\section{Debut Studies}

Elena Tcyplakova

Gamification - the Way of Motivation or Way of Control over the Labor Process?

\section{Professional Reviews}

\section{Maria Sakaeva}

Property Rights in the Focus of Social Theories:

Through Breaking Boundaries towards Interdisciplinary.

\section{New Books}

\section{Elena Melnikova}

How Songs Get on the Radio, or What does Rihanna's Chart Success Mean

for the Researcher of Innovations

Book Review: Rossman G. 2012. Climbing the Charts:

What Radio Airplay Tells Us about the Diffusion of Innovation. Princeton,

NJ: Princeton University Press

\section{Conferences}

\section{Tamara Kusimova}

Education and Social Inequality. XVII April International Academic Conference on Economic and Social Development, April 19-22, 2016, Moscow, Russia.

\section{Tatyana Larkina}

The Questions of Economics History and Methodology.

XVII April International Academic Conference on Economic and Social Development, April 19-22, 2016. Moscow, Russia 


\section{Texts in English}

\section{Inteviews}

Digital Labor and the Sharing Economy: An Interview with Ivana Pais (interviewed by Ivan Pavlyutkin).. 


\section{VR ВСТУПИТЕЛЬНОЕ СЛОВО ГЛАВНОГО РЕДАКТОРА}

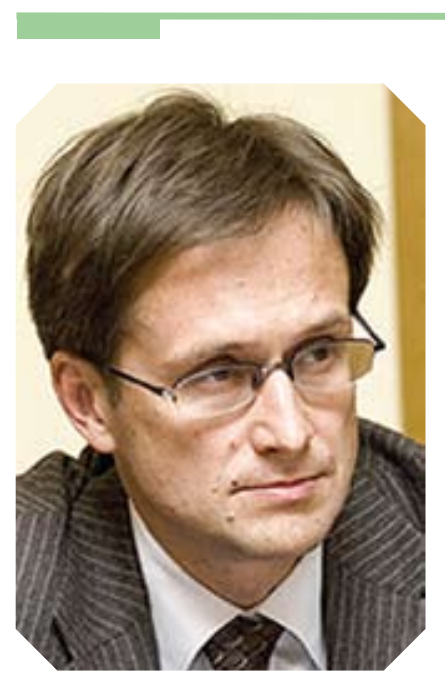

Уважаемые читатели, в начале этого года мы сообщали вам, что журнал «Экономическая социология» включён в базу данных лучших научных журналов России - Russian Science Citation Index (RSCI) на платформе Web of Science. Теперь у нас новое достижение: «Экономическая социология» вошла в ресурс, недавно созданный Thomson Reuters на платформе Web of Science. Речь идёт об индексе цитирования появляющихся источников - Emerging Sources Citation Index (ESCI), который был обнародован в конце 2015 г. Этот индекс входит в состав Core Collection - основного пакета баз на платформе WoS. Ссылки на публикации изданий, входящих в ESCI, учитываются при расчёте цитируемости, индексов Хирша по Core Collection. Статьи, опубликованные в «Экономической социологии», индексируются с 2015 г.

После этого приятного сообщения разрешите представить новый номер журнала.

В рубрике «Новые тексты» мы публикуем статью Я. М. Рощиной (ЛЭСИ НИУ ВШЭ) «Стиль жизни в отношении здоровья: имеет ли значение социальное неравенство?». В исследовании рассматриваются основные составляющие здорового образа жизни: занятия спортом, регулярность питания, отсутствие вредных привычек (таких, как курение и злоупотребление алкоголем и др.). На основе данных «Российского мониторинга экономического положения и здоровья населения НИУ ВШЭ» (The Russia Longitudinal Monitoring Survey - Higher School of Economics, RLMS-HSE) анализируется динамика приверженности населения России этим практикам на протяжении 2000-2014 гг., а также зависимость склонности к здоровому образу жизни от различных социально-экономических факторов. Удалось выявить восемь групп, различающихся индексом риска и преобладающим негативным фактором воздействия на здоровье. Показано значимое влияние социального класса на выбор стиля жизни в отношении здоровья.

В рубрике «Новые переводы» представлен перевод статьи профессора Фрэнка Доббина (факультет социологии Гарвардского университета) «Сравнительный и исторический подходы в экономической социологии». В данной статье представлен обзор исторических и сравнительных исследований в экономической социологии, призванных объяснить многообразие форм хозяйственного поведения в разных странах и в разные времена. Автор подвергает сомнению представление об универсальной и внеисторичной экономической системе и показывает, что для большинства социологов характер экономического поведения зависит от структурных, политических и культурных особенностей общества. Тем не менее в экономической социологии нет доминирующего объяснения: одни исследователи делают ставку на роль социальных сетей, другие - на характер властных отношений, а третьи анализируют институты. Причём эти три подхода всё чаще выступают как взаимодополняющие. Перевод с англ. E. Б. Головляницыной. Публикуется с разрешения издательства Princeton University Press.

В рубрике «Дебюты» публикуется статья E. О. Цыплаковой (магистр социологии НИУ ВШЭ, ведущий аналитик компании «Фабрика Лояльности») «Геймификация - мотивационная практика или механизм тотального контроля над трудовым процессом?». Исследование выполнено методом кейс-стади; источником информации стали интервью с менеджерами и работниками российской компании, производящей алкогольные напитки. Выявлено, что геймификация позиционируется как способ мотивации персонала, но в действительности является в первую очередь способом тотального контроля над трудовым процессом, организованного через автоматизацию труда работников и электронный мониторинг. 
В рубрике «Профессиональные обзоры» размещена работа М. М. Сакаевой (заместитель директора экспертно-аналитического центра Ухтинского государственного технического университета) «Права собственности в фокусе социологических теорий: через размывание границ к междисциплинарности». В обзоре представлены основные теоретические подходы к анализу прав собственности, разработанные в социальных науках. Условия появления и развития этого института рассматриваются с экономических, социологических и междисциплинарных позиций. Особое внимание уделяется неоинституционалистам во главе с Д. Нортом.

В рубрике «Новые книги» $E$. А. Мельникова (аспирант Института образования НИУ ВШЭ) предлагает рецензию на монографию Габриэля Россмана «Поднимаясь в чартах: что радиовещание может рассказать нам о диффузии инноваций» (Climbing the Charts: What Radio Airplay Tells Us about the Diffusion of Innovation. Princeton, NJ: Princeton University Press, 2012). Автор книги пытается ответить на вопрос о том, как песни становятся хитами, какие обстоятельства определяют тот или иной механизм распространения песен. Используя данные о проигрывании в радиоэфире более тысячи случайным образом отобранных синглов, Россман создаёт сложную, изобилующую деталями картину американской музыкальной радиоиндустрии.

В рубрике «Конференции» Тамара Кусимова (НИУ ВШЭ) рассказывает о симпозиуме «Образование и социальная дифференциация», организованном в Высшей школе экономики 19-22 апреля 2016 г., в рамках работы XVII Апрельской международной научной конференции по проблемам развития экономики и общества. В симпозиуме приняли участие учёные из России, стран СНГ, Китая, США, Великобритании, из других стран Европы. Трёхдневное обсуждение концентрировалось на нескольких магистральных темах: сравнительные социальные исследования эффектов от образования; вопросы адресной социальной политики по снижению неравенства; исследования неформального образования и направления для дальнейших исследований.

Разговор о XVII Апрельской международной научной конференции НИУ ВШЭ продолжает Татьяна Ларкина (стажёр-исследователь ЛЭСИ НИУ ВШЭ), рассказывающая о работе секции «Методология экономической науки» под руководством профессора НИУ ВШЭ Владимира Автономова. Предметом внимания докладчиков были вопросы теоретико-методологического характера, истории экономической науки, а также практического применения теоретического знания.

В разделе на английском языке в рубрике «Интервью» профессор факультета социологии Католического университета Святого Сердца (Università Cattolica del Sacro Cuore, UCSC) (Милан, Италия) Ивана Паис (Ivana Pais) рассказывает о своей карьере экономсоциолога, о более ранних и нынешних исследовательских проектах. Она также объясняет специфику развития экономической социологии в Италии. Ивана делится взглядами об особой важности цифровой экономики для более полного понимания рыночных процессов и говорит о своём текущем исследовании экономики совместного пользования (sharing economy). Наконец, она анонсирует будущую конференцию в Бёркли. Интервью записано И. В. Павлюткиным (ЛЭСИ НИУ ВШЭ).

Первый онлайн-курс «Экономическая социология» (лектор — В. Радаев) на Национальной платформе открытого образования (НПОО) подошёл к своему концу. Завершается итоговое тестирование слушателей. Повторение курса состоится, видимо, уже в следующем году. А вот на глобальной платформе Coursera этот курс продолжается. Здесь применяется когортный подход - на смену одной когорте слушателей приходит другая.

Запись на Coursera: https://www.coursera.org/learn/econom-sociology 


\section{VR INTRODUCTORY REMARKS}

Dear colleagues,

We have already informed you that Journal of Economic Sociology was accepted to the Russian Science Citation Index of the Web of Science. Now we have one more achievement to share with you. Thomson Reuters has launched the Emerging Sources Citation Index (ESCI), which will include high-quality, peer-reviewed publications of regional importance and in emerging scientific fields. ESCI will also make content visible in the Web of Science Core Collection even if it has not yet demonstrated citation impact on an international audience. The Journal of Economic Sociology has been included in this important Index.

After this good news, let us introduce the new issue of the journal.

Yana Roshchina's (NRU HSE) paper “Health-Related Lifestyle: Does Social Inequality Matter?” investigates important practices associated with a healthy lifestyle (e.g., playing sports, eating nutritious foods regularly, avoiding smoking, and not abusing alcohol). RLMS-HSE data were used to analyze how the percentage of Russians using these practices changed from 2000 to 2014, and how the adherence to a healthy lifestyle depended on different socio-economic factors. Eight groups leading divergent health-related lifestyles are clustered. It is demonstrated that social class significantly influences the choice of health-related lifestyle.

In the section "New Translations," Professor Frank Dobbin's (Department of Sociology, Harvard University) paper "Comparative and Historical Perspectives in Economic Sociology" reviews historical and comparative theories in economic sociology that seek to explain the substantial differences in economic behavior across time and space. The author challenges the idea of a universal economic system and shows that for most sociologists, structural, political, and cultural features shape economic behavior. However, scholars have not reached a consensus on a predominant explanation: some researchers focus on the role of social networks, others on power relations, and still others on social institutions-conventions. Remarkably, recent studies increasingly refer to them as complementary. The paper is translated into Russian by Ekaterina Golovlyanitsyna. It is published with the permission of Princeton University Press.

Elena Tcyplakova's (MA in Sociology, Higher School of Economics; Senior Product Analyst, LoyaltyPlant Russia) study "Gamification - the Way of Motivation or Way of Control over the Labor Process?" analyzes gamification as a new way of controlling the labor process. Data were collected from 16 semi-structured interviews with the managers and employees of a Russian company that produces alcoholic beverages. It was revealed that although gamification is positioned as a motivator, it is used primarily to impose tighter control over the labor process and is arranged by automatic operations and electronic monitoring.

Maria Sakaeva's (Deputy Director, Centre of Expertise and Analytics, Ukhta State Technical University) paper "Property Rights in the Focus of Social Theories: Through Breaking Boundaries towards Interdisciplinary" reviews the main theories of property rights developed by the social sciences. Economic, sociological, and interdisciplinary approaches to character and the evolution of property right institutions are discussed with a special reference to the new institutional economics and Douglass North in particular.

Elena Melnikova (Institute of Education, NRU HSE) reviews Gabriel Rossman's book Climbing the Charts: What Radio Airplay Tells Us about the Diffusion of Innovation. The author tries to figure out how songs get on the radio. Drawing upon the "gatekeeping model" of Paul Hirsch, Rossman analyzes the channel from distributors (record labels) to surrogate consumers (radio stations). Using data collected from the cumulative airplay of more than a thousand randomly selected singles, the author presents a detailed picture of the US radio industry 
Tamara Kusimova reviews the Symposium on the Role of Education in the Reproduction and Reduction of Social Inequalities arranged in April 2016 at the National Research University Higher School of Economics in Moscow during the XVII April International Academic Conference on Economic and Social Development. Several main aspects were highlighted during the three-day discussion, including comparative cross-national research on effects of educational opportunities, implications for social policy, studies of informal education, and prospects for further research.

Tatyana Larkina continues the discussion of the outcomes of the XVII April International Academic Conference on Economic and Social Development. She reviews the Section "Economic Methodology" moderated by HSE professor Vladimir Avtonomov. The theoretical and methodological nature of economics and the history of economic thought and practical applications of theoretical knowledge were in the spotlight.

\section{Texts in English}

Professor Ivana Pais (Department of Sociology of the Catholic University of the Sacred Heart in Milan) was interviewed to discuss her career path as an economic sociologist and some of her previous and current research projects. She also explains the specific features of economic sociology in Italy. In this interview, Pais shares her insights regarding the significance of the digital economy for a better understanding of market development and speaks about her current research on the sharing economy. Finally, Pais shares her participation in a conference arranged by the European Commission and announced a future mini-conference in Berkeley. Interview was recorded by Ivan Pavlyutkin (NRU HSE).

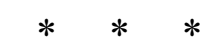

The first Massive Open Online Course "Economic Sociology" is coming to an end on the Russian National Platform of Open Education with Vadim Radaev as Lecturer. The students are taking their final tests. The course will start anew by the next year on this platform.

As for the global platform Coursera, this lecture course is available online. A cohort approach is being used where one cohort of students replaces the previous one.

You can enroll for this course at Coursera: https://www.coursera.org/learn/econom-sociology 


\section{НОВЫЕ ТЕКСТЫ}

\section{Я. М. Рощина}

\section{Стиль жизни в отношении здоровья:} имеет ли значение социальное неравенство ? ${ }^{1}$

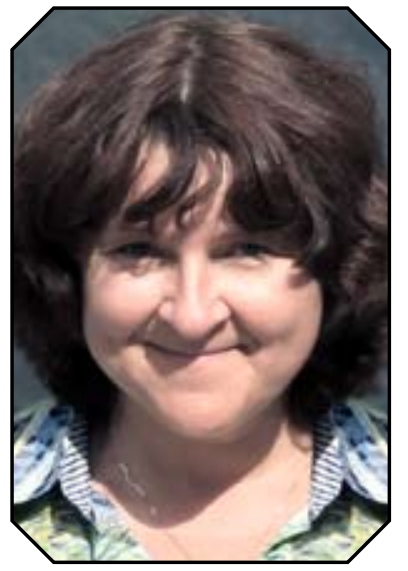

\section{РОЩИНА Яна}

Михайловна - кандидат экономических наук, доцент кафредры экономической социологии, ведущий научный сотрудник Центра лонгитюдных исследований, старший научный сотрудник Лаборатории экономикосоциологических исследований Национального исследовательского университета «Высшая школа экономики». Адрес: 101000, Россия, г. Москва, ул. Мясницкая, д. 20.

Email: yroshchina@hse. ru
В исследовании рассматриваются различные составляющие здорового образа жизни (занятия спортом, регулярность питания, отсутствие вредных привычек, таких как курение и злоупотребление алкоголем, и др.). На основе данных «Российского мониторинга экономического положения и здоровья населения НИУ ВШЭ» (The Russia Longitudinal Monitoring Survey - Higher School of Economics, RLMS-HSE) ${ }^{2}$ анализируются динамика приверженности населения России этим практикам на протяжении 2000-2014 г2., а также зависимость склонности к здоровому образу жсизни от различных сочииально-экономических факторов. Кластерный анализ не опроверг гипотезу о наличии широкого спектра стилей жизни между полюсами наиболее и наименее здорового в зависимости от различий основных факторов, влияющих на здоровье. Таким образом, помимо двух крайних групп («здоровый» и «нездоровый» стиль жизни), удалось выявить ещё шесть, различающихся как индексом риска, так и преобладающим негативным фактором воздействия на здоровье. Регрессионный анализ показал значимое влияние социального класса на выбор стиля жизни в отночении здоровья (по сравнению с «нейтральнылм»), при прочих равных условиях, для всех стилей, кроме «умеренного риска». Модель с включением в качестве регрессоров дамми-переменных сочиальных классов оказалась лучше интерпретируема, чем та, где используются отдельные показатели сочиоэкономического статуса (образование, доход и профессиональный статус). Таким образом, для классов «высший» и «выстий средний» наиболее характерны стили жизни «здоровый» и «профилактический»; для класса «средний средний» — «вредная работа», для обоих низших классов - стили «пассивный» и «курящий», для «низшего низшего» класса - «нездоровый» образ жизни, ассоииированный с высоким потреблением алкоголя.

Ключевые слова: стиль жизни в отношении здоровья; социальный класс; вредные привычки; здоровый образ жизни; потребление алкоголя; занятия спортом.

\footnotetext{
В данной научной работе использованы результаты проекта «Мониторинг социальноэкономического поведения домохозяйств и распространённость практик здорового образа жизни», выполненного в рамках Программы фундаментальных исследований НИУ ВШЭ в 2015 г. Автор признателен участникам семинара «Социология рынков» Лаборатории экономико-социологических исследований НИУ ВШЭ за советы и идеи при обсуждении результатов исследования.

2 Проводится Национальным исследовательским университетом «Высшая школа экономики» и ЗАО «Демоскоп» при участии Центра народонаселения Университета Северной Каролины в Чапел-Хилле и Института социологии PAH (см. URL: http://www.hse. ru/rlms).
} 
Здоровье признаётся как одним из важнейших компонентов благополучия человека (в том числе и своего рода потребительском благом), так и фактором, влияющим на доходы и другие возможности. На уровне общества в целом уровень здоровья населения отражает социальную и экономическую ситуацию [Bloom, Canning 2000]. Один из важнейших показателей здоровья населения - ожидаемая продолжительность жизни (ОПЖ) — входит в расчёт показателя «индекс человеческого развития» [Горина 2012; Малик 2014]. По данным Всемирной организации здравоохранения (ВО3), в 2013 г. по ожидаемой продолжительности жизни при рождении (69 лет) Россия занимала 127-е место (из 194 стран), а по ОПЖ мужчин (63 года) - 144-е место 3 .

Разумеется, возможности сохранения здоровья существенно зависят от доходов населения и уровня развития медицины [Starfield 2000]. Так, самая высокая ОПЖ — в Японии, Сингапуре и Европе, а самая низкая - в странах Африки. Однако в экономически развитых странах, как утверждается в ряде исследований, всё большая роль в поддержании ОПЖ принадлежит образу жизни [Glorioso, Pisati 2014]. Среди важнейших с точки зрения здоровья составляющих образа жизни, как правило, выделяют курение и потребление алкоголя, физическую активность и питание [Glorioso, Pisati 2014].

Неудовлетворительное состояние здоровья и болезни населения приводят к издержкам как для самих людей, так и для фирм и государства. Следствием высокой смертности и низкой продолжительности жизни является снижение объёма трудовых ресурсов. Уменьшаются также объём производства и производительность труда, что негативно сказывается на доходах. Государство несёт издержки по расходам на медицинские услуги в рамках обязательного медицинского страхования, а население и работодатели - на добровольное медицинское страхование и платную медицинскую помощь.

Неудивительно поэтому, что политика, направленная на формирование здорового образа жизни (ЗОЖ), разрабатывается во многих странах. Так, в 2013 г. была принята программа Европейского отделения ВО3 «Здоровье 2020: основы европейской политики в поддержку действий всего государства и общества в интересах здоровья и благополучия». В России за последнее десятилетие также принят ряд программ, направленных на охрану здоровья нации: «Государственная программа развития здравоохранения на 2013-2020 гг.», а также другие программы, направленные на сокращение потребления алкоголя и табака, на развитие физической культуры и спорта, правильного питания. Однако до сих пор значительное число мер, принятых в этой сфере, носят, скорее, запретительный характер (запрет курения в общественных местах, повышение цен на алкоголь, запрет на его продажу в ночное время и т. д.). В то же время именно осознание людьми влияния их поведения на состояние собственного здоровья могло бы сыграть наиболее важную роль.

В ряде исследований, в том числе российских, проводилась оценка влияния поведения человека на состояние его здоровья (см., например: [Рощина 2009]), а также факторов, способствующих приверженности вредным привычкам. Однако остаются неясными именно распространённость сочетаний различных практик, то есть типов стилей жизни в отношении здоровья (СЖ3) ${ }^{4}$, а также наличие их взаимосвязи с социальным положением и другими характеристиками (например, пол, возраст, образование и т. д.). В данном исследовании мы постараемся выделить несколько различных СЖЗ в современной России и выявить наличие взаимосвязи между стилем жизни в отношении здоровья и социальным классом, к которому принадлежит индивид. Для этого сначала мы остановимся на обзоре социологических концепций СЖЗ и соответствующих эмпирических исследований. Затем будет описана методология исследования и представлены результаты анализа данных.

3 CM. URL: http://apps.who.int/gho/data/node.main.688?lang=en

4 Мы будем использовать понятие «стиль жизни в отношении здоровья» (health lifestyle, или health-related lifestyle) вслед за У. Кокерхамом (см. ниже). В русскоязычной литературе устоявшегося соответствующего термина пока нет. 


\section{Стиль жизни в отношении здоровья как объект теоретического анализа}

Теоретический аспект здоровья как одного из видов человеческого капитала, или даже как специфического вида капитала, был разработан М. Гроссманом [Grossman 2000]. Согласно этой концепции человек рождается с определённым уровнем (запасом) капитала здоровья. Этот капитал, с одной стороны, подлежит износу с возрастом, а с другой - может увеличиваться или уменьшаться также под влиянием различных факторов, выступающих как инвестиции в здоровье. При этом одни из них могут иметь позитивное влияние (например, правильное питание, физическая активность, медицинские услуги), а другие - негативное (например, курение, чрезмерное употребление алкоголя и т. д.). Здоровье одновременно и является потребительским благом для человека (повышая уровень функции благосостояния), и обладает свойствами капитала, имеющего отдачу. Это связано с тем, что высокий уровень здоровья сокращает вероятность заболеваний, которые снижают размер заработков из-за пропущенных по болезни дней. В этом отношении важен вывод М. Гроссмана о том, что люди с более высокими доходами и образованием будут склонны к более высоким инвестициям в своё здоровье.

Как было показано в социологии, существует определённая комплексность в сочетании различных видов поведения человека, что привело к возникновению понятия «стиль жизни». Наибольший вклад в разработку теории этого термина, в определение его взаимосвязи с социальным классом и габитусом внёс П. Бурдьё [Bourdieu 1984]. Под стилем жизни он понимал позиции индивида в социальном пространстве, определяемые через его практики и связанные с классом, которому он принадлежит. П. Бурдьё также показал, что важнейшая роль в структуре стиля жизни принадлежит соотношению культурного и экономического капиталов.

У. Кокерхам связал понятия «стиль жизни» и «здоровье» [Cockerham 2005], введя категорию «стиль жизни в отношении здоровья» (health lifestyle). В своей работе он показывает, что многочисленные эмпирические исследования позволяют подтвердить взаимосвязь практик, влияющих на здоровье, и социального класса. Предложенная Кокерхамом модель основывается на концепции П. Бурдьё: стиль жизни как упорядоченная система практик зависит от социального положения человека, его позиции в социальном пространстве и опирается на объём и соотношение экономического и культурного капитала. Кокерхам определил стиль жизни в отношении здоровья как «коллективные модели поведения в отношении здоровья, являющиеся результатом индивидуального выбора возможностей, которыми люди располагают в соответствии с их позицией в социальной структуре» [Cockerham 2005: 55]. Различные практики человека влияют на состояние здоровья (позитивно или негативно), а их предпочтение зависит от габитуса. В свою очередь, габитус формируется на основе условий жизни человека и его позиций в социальной структуре. В ряде эмпирических исследований, как отмечает Кокерхам, показано, что людям из высшего и среднего классов более свойствен здоровый образ жизни (ЗОЖ), чем представителям низших классов. Кокерхам также выделяет ряд факторов, воздействующих на стиль жизни в отношении здоровья: социальный класс; демографические характеристики (пол, возраст, раса); условия жизни и социальные группы (такие, как сообщество на работе, соседи, политика и т. д.). Эти факторы влияют на социализацию, жизненные шансы, а через них — на «жизненный выбор» (по Веберу) и габитус, который, в свою очередь, определяет практики, в той или иной степени - позитивно или негативно - оказывающие воздействие на здоровье. Ранее подобный подход был предложен С. Уильямсом [Williams 1995].

\section{Эмпирические исследования стиля жизни в отношении здоровья}

Теорию Кокерхама для анализа эмпирических данных применили В. Кристенсен и Р. Каприано [Christensen, Capriano 2014]. Результаты показали, что индекс массы тела датских женщин зависит от их принадлежности к социальному классу. Ч. Чан и С. Леунг [Chan, Leung 2014] на основе кластерного 
анализа данных по Гонконгу, с учётом интенсивности занятий спортом и правильного питания выделили два стиля жизни - «здоровый» и «менее здоровый». К менее здоровому стилю жизни, согласно результатам, более склонны мужчины, молодые люди, занятые и имеющие более высокое образование.

На основе данных опроса населения Италии в 2005 г. В. Глориозо и М. Пизати [Glorioso, Pisati 2014] выделили 13 различных стилей жизни в отношении здоровья, используя следующие переменные: индекс массы тела (ИМТ); частота физической активности; курение; частота измерения ИМТ; соблюдение диеты; прохождение основных медицинских тестов (измерение уровня холестерина и т. д.); обращение к нетрадиционной медицине. Авторы также показали, что существует статистически значимая взаимосвязь между стилем жизни и социоэкономическим статусом: в первую очередь к здоровому образу жизни склонны люди с более высоким уровнем образования.

Коллектив авторов [Неikilä et al. 2013] на данных по шести европейским странам выявил наличие взаимосвязи нездорового образа жизни и стресса на работе. При этом здоровым образом жизни считалось сочетание следующих практик: нормальный вес, отсутствие потребления табака, умеренное потребление алкоголя (не более 140 г этанола для женщин и 210 г для мужчин в неделю) и физическая активность во время досуга (2,5 ч и более умеренной нагрузки или 1,25 ч и более высокой нагрузки в неделю). К нездоровому стилю жизни были отнесены, напротив, сочетание лишнего веса, курения, избыточного потребления алкоголя и низкой физической активности.

В России также проводятся исследования стиля жизни и его влияния на здоровье. В целом люди в нашей стране в недостаточной степени осознают, что их образ жизни влияет на здоровье. Согласно исследованию С. Варламовой и Н. Седовой, основной причиной ухудшения здоровья люди считают низкий уровень жизни; лишь 5\% опрошенных назвали курение и $1,7 \%$ - чрезмерное употребление алкоголя [Варламова, Седова 2010]. Похожие результаты были получены в исследовании С. Ефименко [Ефименко 2007].

В исследовании А. Ковалёвой были выделены четыре группы населения по отношению к ЗОЖ: две крайние - «внимательно относящиеся к здоровью» и «невнимательно относящиеся к здоровью», а также две промежуточные [Ковалёва 2008]. Эти группы оказались связанными с некоторыми социальноэкономическими характеристиками. Исследование РБК, проведённое в 2013 г., показало, что склонность к более здоровому стилю жизни зависит от социально-экономических характеристик 5 . Согласно полученным результатам, 59\% опрошенных россиян (в возрасте 18-54 лет) полагают, что ведут здоровый образ жизни. При этом с увеличением дохода растёт и доля тех, кто считает себя его приверженцем. Несколько выше доля ведущих активный образ жизни среди молодых людей (до 34 лет) и более обеспеченных 6 .

В исследовании М. Колосницыной и А. Бердниковой рассматривалась одна из важных составляющих стиля жизни в отношении здоровья: отсутствие избыточного веса [Колосницына, Бердникова 2009]. Лишний вес и тем более ожирение могут оказывать негативное влияние на склонность к заболеваниям [Рощина 2009] и выступают как индикатор вредных привычек: прежде всего неправильного питания и отсутствия физической активности. Согласно обзору зарубежных исследований, наиболее сильными детерминантами нормального веса выступают высшее образование и высокие доходы. Однако на российских данных авторы установили, что с ростом уровня образования склонность к лишнему весу у женщин понижается, а у мужчин — растёт.

5 Cм. URL: http://marketing.rbc.ru/reviews/medicine2013/

6 См. URL: http://marketing.rbc.ru/reviews//medicine2013/chapter_5_5.shtml 
Таким образом, теоретические идеи и имеющиеся эмпирические исследования позволяют выдвинуть следующие гипотезы относительно СЖЗ в России:

Гипотеза 1 (H1). Можно выделить группу людей, склонных к здоровому стилю жизни (не курят, умеренно потребляют алкоголь, занимаются спортом, имеют нормальный вес, нормальную продолжительность рабочего дня и т. д.), и, напротив, группу людей, ведущих нездоровый образ жизни, а также несколько промежуточных групп, в стиле жизни которых преобладает тот или иной фактор, оказывающий негативное влияние на здоровье.

Гипотеза 2 (H2). Люди из более высоких социальных классов будут выбирать те типы стиля жизни, которые благоприятно влияют на здоровье.

Гипотеза 3 (H3). К здоровому образу жизни более склонны женщины, люди с высшим образованием, обеспеченные и более молодого возраста.

\section{Методология исследования}

Цель данного исследования - построить типологию населения России по типу стиля жизни в отношении здоровья (СЖЗ), а также выявить факторы, которые определяют выбор того или иного СЖЗ, в первую очередь - влияние социального класса. Объектом выступает население России в возрасте 14 лет и старше, а предметом - типы и факторы стиля жизни россиян в отношении здоровья.

Эмпирическая основа - данные репрезентативного панельного исследования RLMS-HSE за 1994-2014 гг. для анализа динамики отдельных показателей СЖЗ и данные за 2010-2014 гг. для выявления типов стиля жизни в отношении здоровья, под которым будем понимать соотношение практик человека, могущих иметь позитивные и негативные последствия для состояния его здоровья. В данных RLMS-HSE есть переменные о таких практиках, как занятия физической культурой и спортом; профилактические посещения врача; приём витаминов и биодобавок; регулярность питания; следование диете; наличие избыточного веса; продолжительность рабочего дня; вредный характер производства; употребление алкоголя; курение. Мы кратко рассмотрим динамику по каждому из этих показателей, а также различия в следовании практикам СЖЗ в 2010-2014 гг. в разрезе следующих факторов: пол; возраст; образование; доходы (квинтильные группы); здоровье; социальный класс; занятость.

Переменная «социальный класс» была сконструирована нами для 1994-2014 гг. по методике Европейского общества по опросам общественного мнения и маркетинговым исследованиям (European Society of Marketing Research Professionals, ESOMAR), с учётом особенностей России, как это делает, например, компания Synovate Comcon ${ }^{7}$. В данной методике социальный класс определяется на основании статуса члена семьи, приносящего основной доход (Main Income Earner - M.I.E.), по следующим критериям: занятость, профессиональный статус (с учётом количества подчинённых), уровень образования, имущественный статус семьи (для незанятых). В данной работе будет использована следующая стандартная классификация: $A-$ высший класс; $B, C 1$ и $C 2-$ средние классы (соответственно высший средний, средний средний и низший средний); $D$ - низший и $E$ - низший низший классы. Выделенные по такой методике социальные классы различаются по объёму экономического и культурного капитала, согласно идее П. Бурдьё, и, как показывают исследования в России и за рубежом, придерживаются разных стилей жизни, что позволяет ожидать их приверженность отличающимся практикам в отношении здоровья.

7 Описание методологии Synovate Comcon и сконструированных классов см.: URL: http://www.comcon-2.ru/default. asp? artID=1937. В отличие от этой методологии мы не учитывали для занятых, является предприятие государственным или частным. 
Далее будет представлена модель факторного анализа на основе переменных, измеряющих разные практики по отношению к здоровью, которые перечислены выше, что позволит выявить основные независимые векторы типов поведения в этом поле социального пространства. Их количество служит основанием для определения потенциального числа кластеров в типологии СЖЗ.

Затем мы опишем результаты кластерного анализа (методом $K$-средних) на объединённом массиве данных за 2010-2014 гг. для выявления стилей жизни в отношении здоровья на основе указанных выше отдельных переменных о приверженности каждой из практик (выделенные факторы не использовались в данной модели, так как это существенно снижает объём учитываемой информации). Наконец, будут представлены результаты оценки мультиномиальной логистической регрессии также на объединённом массиве за 2010-2014 гг. ${ }^{8}$. Эта регрессия была использована для обнаружения факторов, влияющих на принадлежность к каждому из выявленных стилей жизни. Зависимая переменная - номер кластера; детерминанты модели согласно гипотезе 2 - дамми описанных выше социальных классов, или как альтернатива - образование, занятость, профессиональный статус и доходы. Гипотеза 3 предполагает включение в модель и таких независимых переменных, как пол и возраст (а также упомянутые выше образование и доходы). В качестве контрольных использовались такие характеристики, как семейное положение, наличие детей, уровень здоровья в прошлом году, тип населённого пункта, региональный уровень безработицы и доходов.

\section{Динамика состояния здоровья населения и его приверженности различным практикам СЖ39}

\section{Состояние здоровья}

В статистике есть несколько показателей, характеризующих уровень здоровья населения. Основными из них можно назвать ожидаемую продолжительность жизни при рождении (ОПЖ), уровень смертности и заболеваемость населения (зарегистрированное число больных с диагнозом, установленным впервые в жизни, на 100 чел. населения). По всем этим показателям здоровье россиян хотя и улучшилось с начала 2000-х гг., однако отстаёт от развитых стран мира (например, в большинстве из них ОПЖ превышает 75 лет у мужчин и 80 лет у женщин $\left.{ }^{10}\right)$. ОПЖ в России после катастрофического падения в середине 1990-х гг. (57,4 года среди мужчин и 71,1 года среди женщин) стала расти и достигла 65,3 года для мужчин и 76,5 года для женщин (это выше, чем было в 1990 г.). Начиная с 2004 г. в России постепенно снижался и уровень смертности, к 2014 г. он достиг величины 13,1. Это сопоставимо с такими странами, как Белоруссия, Венгрия, Румыния, но существенно больше, чем в странах Западной Европы. Рос также уровень заболеваемости: согласно данным Росстата, в 1990 г. он составлял 65 чел., а в 1992 г. — 61,5 на 100 чел. населения и в дальнейшие годы постепенно повышался, достигнув к 2013 г. 79,9 чел.

Обратимся теперь к данным RLSM-HSE. Далее будем рассматривать только население в возрасте от 14 лет, опрошенное по анкете для взрослых. Что касается самооценки здоровья, то она улучшилась: доля тех, кто оценивал его как «плохое или очень плохое», за 1994-2014 гг. упала с 15,7 до 10,2\%, а как «хорошее или очень хорошее» - выросла с 31,6 до 44,5\%. Снизилась и доля людей с хроническими заболеваниями: если в 2000 г. хотя бы одно хроническое заболевание из семи, включённых в вопросник, имели 44\% опрошенных, то в 2014 г. - 36\%. Неудивительно, что самооценка здоровья с возрастом

8 В связи с использованием объединённого массива (pooled data) был рассчитан скорректированный уровень значимости коэффициентов (метод cluster).

9 Более подробно о динамике отдельных показателей СЖЗ и их связи с социальным классом см.: [Рощина, Гремченко 2016].

10 См. URL: http://demoscope.ru/weekly/app/app4011.php 
падает, а заболеваемость растёт. Несколько неожиданным на первый взгляд выглядит более высокая заболеваемость обеспеченных людей по сравнению с бедными. Если рассматривать различия между социальными классами, то оказывается, что самая высокая доля имеющих хронические заболевания - в низшем низшем классе (71\%), тогда как в среднем классе - не выше $60 \%$, а в высшем - $61 \%$. Однако в низшем классе сосредоточена значительная часть малообеспеченных пенсионеров, что может объяснять влияние, скорее, возраста, чем социального статуса.

\section{Занятия спортом}

По данным RLMS-HSE, менее 1/5 населения занимается каким-либо видом спорта. Эта доля лишь немного выросла за 2000-2014 гг. (с 17 до 19\%), как и средняя продолжительность занятий для тех, кто занимается спортом (с 8,8 до 10,4 ч в месяц). Вполне отвечает гендерным стереотипам то, что мужчины больше вовлечены в спорт, чем женщины. Доля занимающихся спортом среди мужчин составляла в 2014 г. 23\%, а продолжительность - 12,8 ч в месяц; среди женщин - 16,4\% занимающихся, а продолжительность - 7,9 ч в месяц. Что касается различий по возрасту, то наибольшая доля «спортсменов» среди тинейджеров - 67,3\%. Затем физическая активность существенно снижается: в возрастной группе 18-24 года занимаются спортом 38\%, в группе $25-34$ года $-21 \%$, в группе 35-44 года $17,5 \%$, в группе $45-54$ года - 12,2\%. В то же время показательно, что с ростом дохода и образования люди больше занимаются спортом, хотя это сказывается именно на доле занимающихся, а не на продолжительности занятий. Кроме того, можно выделить наиболее характерные для обеспеченных виды спорта: помимо ходьбы, это занятия на тренажёрах и плавание. Среди социальных классов доля занимающихся спортом выше всего (28-30\%) в классах $A$ (высший), $B$ (высший средний) и $C 1$ (средний средний), ниже всего (15 и 10\% соответственно ) в классах $D$ (низший) и $E$ (низший низший). В то же время нельзя исключать и параллельное влияние возраста, так как в этих классах много пенсионеров.

\section{Питание и приём витаминов}

Доля принимающих витамины и минеральные добавки в 2006-2014 г. практически не изменилась (около 19\%), как и придерживающихся диеты (9,5\% в 2014 г.). Но за 2010-2014 гг. с 52 до 57,7\% выросла доля тех, кто оценивал своё питание как определённо регулярное. Придерживаться правильного питания более склонны люди с плохим здоровьем, более старшего возраста, а также женщины. Влияние дохода неоднозначно. Бедные чаще питаются дома, и их питание можно назвать регулярным, однако богатые более склонны употреблять витамины и пищевые добавки, а также придерживаются диеты. Примерно таково же влияние образования: люди с университетским дипломом чаще пьют витамины, придерживаются диеты (чем остальные группы); с общим средним образованием — питаются дома; а со средним профессиональным - питаются регулярно.

\section{Избыточный вес}

Напрямую избыточный вес не является компонентой здорового стиля жизни. Однако, во-первых, он может служить индикатором того, что люди неправильно питаются, ведут неактивный образ жизни или имеют какие-то физиологические проблемы со здоровьем, а во-вторых, людям с высокой массой тела труднее, например, заниматься спортом. Как правило, оценка избыточного веса производится на основании расчёта индекса массы тела (ИМТ), который равен результату деления массы в килограммах на квадрат роста в метрах. Обычно считается, что если ИМТ меньше или равен 25, то вес в норме, если 25-30 - вес избыточный, более 30 - ожирение [Колосницына, Бердникова 2009: 72, 80]. Данные RLMS-HSE показывают, что средний ИМТ в расчёте на всё население старше 14 лет за 1994-2014 гг. вырос среди женщин с 25,9 до 26,7, а среди мужчин — с 24,5 до 25,7. Во все годы ИМТ выше среди женщин и людей старшего возраста. В целом среди самой бедной группы выше доля людей с ИМТ 
в норме $(47,7 \%)$. Что касается социального класса, то лучше всего обстоят дела в средних классах $C 1$ (средний средний) и $C 2$ (низший средний): у половины представителей этих групп ИМТ не превышает нормы, чуть менее $30 \%$ имеют лишний вес и $19-20 \%$ - ожирение. В классах $A$ (высший) и $B$ (высший средний) доля людей с ожирением больше: 23-24\%, но самая плохая ситуация в низшем низшем классе $E: 29 \%$ страдают ожирением и $32 \%$ имеют лишний вес.

\section{Продолжительность рабочего дня}

Для занятого населения продолжительность рабочей недели сильно ограничивает возможности вести здоровый образ жизни. В целом за 1994-2014 гг. продолжительность рабочего времени с учётом возможности работы в нескольких местах выросла. Если в 1994 г. женщины в среднем работали 143,7 ч в месяц, то в 2014 г. - уже 164,5 ч, а мужчины - 165,5 и 179,6 ч соответственно. Кроме того, слишком большая нагрузка на работе может приводить к стрессу (например, в 2014 г. 6,4\% занятых трудились более 60 ч в неделю). Продолжительность рабочей недели выше среди мужчин, а также среди тех, кто занимает управленческие позиции. Весьма существенное влияние на здоровье может также оказывать вредный характер производства. Согласно данным RLMS-HSE, доля тех, кто считает, что он работает на вредном производстве, составляла 15\% в 2004 г. и 14\% в 2014 г., достигая максимума в 2006 г. (17,8\%). Доля мужчин, работающих во вредных условиях, выше (16\%), чем женщин (14\%), а богатых — выше (16\%), чем бедных (12\%).

\section{Курение}

Один из важнейших негативно воздействующих на здоровье факторов — это, безусловно, курение. Причём если умеренное потребление алкоголя, прежде всего вина, по оценкам медиков, может быть полезным для здоровья, то курение даже в малых количествах безоговорочно вредно. Исходя из гендерных стереотипов, неудивительно, что в России женщины курят меньше мужчин. Однако за 1994-2014 гг. среди женщин доля курящих выросла с 9 до 14\%, а среди мужчин - упала с 58 до 49\%. Таким образом, принятые в последние годы меры по запрету курения в общественных местах и рост цен на сигареты привели к снижению доли курильщиков только среди мужчин, хотя объём курения даже вырос. Выше всего доля курильщиков среди людей в возрасте 25-44 года (то есть зависимость от возраста квадратичная), а объём курения - в возрасте 45-64 года (то есть объём выкуриваемого падает только у людей старше 65 лет). Зависимость вероятности курить от душевого дохода также близка к квадратичной: выше всего доля курящих среди самых бедных (35,5\%) и богатых (31\%) по сравнению с людьми со средними доходами $(27,8 \%)$. А вот объём курения от дохода практически не зависит. Примерно такая же ситуация и с социальным статусом: меньше всего (23\%) доля курящих в двух верхних классах, больше всего (32\%) - в классах $C 2$ (низший средний) и $D$ (низший), в классе $E$ (низший низший) она снова снижется до 30\%. Однако больше всего сигарет выкуривает высший класс $(A): 17$ сигарет в день, меньше всего — высший средний $(B)$ : 15 сигарет в день.

\section{Чрезмерное употребление алкоголя}

Ещё одной вредной привычкой по праву считается чрезмерное употребление алкоголя. Но если в случае курения наличие такой привычки автоматически относит индивида к группе тех, кто ведёт не вполне здоровый образ жизни, то с употреблением алкоголя ситуация сложнее. Всем известно, что в таких странах, как Испания, Италия или Франция, бокал вина за ужином или обедом считается нормой и, как говорят врачи, даже полезен для здоровья. В 1994-2014 гг. доля тех, кто употреблял алкоголь в течение 30 дней перед проведением опроса, упала с 55,7 до 42,7\%, в том числе среди женщин - с 44 до 34\%, а среди мужчин - с 70 до 52,6\%. Что касается абсолютных трезвенников, то мы можем определить их долю начиная с 2006 г.: она выросла с 27 до 36\%. Объём потребления алкоголя, выраженный в чи- 
стом этаноле, в расчёте на всё население от 14 лет и старше (включая непьющих), согласно данным RLMS-HSE, тоже уменьшился: с 215 г в месяц до 153 г. Однако снижение потребления происходило прежде всего в результате уменьшения доли пьющих, а не объёма потребления в расчёте на одного потребителя. Наиболее высока доля потребителей в возрастной группе 35-44 года (77\%), а самый высокий объём потребления среди пьющих в группе 45-54 года (почти 500 г в месяц). Доля пьющих выше всего среди тех, кто считает своё здоровье средним (70\%), однако наивысшие частота потребления (6 раз в месяц) и объём (600 г этанола) среди тех, чьё здоровье, по самооценке, плохое. В данном случае, вероятно, мы также наблюдаем и негативное влияние на здоровье прошлого потребления, и эффект привыкания. Среди богатых выше всего доля потребителей (72\%, тогда как среди бедных 55\%), однако среди пьющих бедных самый высокий объём потребления (480 г этанола в месяц). Та же тенденция заметна и для социального класса: в классе $A$ (высший) доля потребителей алкоголя $69 \%$, и каждый из них в среднем выпивает 350 г этанола, а в классе $E$ (низший низший) пьют 56\%, но объём потребления - более полулитра. Меньше всего пьют в классах $B$ (высший средний) и $C 1$ (средний средний).

\section{Посещение врача с профрилактической целью}

К здоровому образу жизни может быть отнесено посещение врача с профилактической целью, а не в результате какого-либо заболевания. Это помогает ранней диагностике и, как следствие, сохранению здоровья. Согласно данным RLMS-HSE, за 1994-2014 гг. посещаемость врача с профилактической целью (в течение трёх месяцев перед проведением опроса) не изменилась: и в 1994 г., и в 2014 г. она составляла 19\%. Примечательно, что различий в посещениях врача с профилактической целью в зависимости от самооценки здоровья практически нет. Велики гендерные различия: если среди женщин ходят к врачу с профилактической целью $21 \%$, то среди мужчин - $17 \%$. Это может служить основой как для различий в диагностике (женщины чаще мужчин сообщают о наличии у себя хронических заболеваний), так и в отношении к поддержанию здоровья (о чём говорит более высокая смертность среди мужчин). Чаще практикуют такие посещения богатые (24\%), чем бедные (15\%); по уровню образования различия невелики. Эта практика наиболее характерна для среднего класса $C 1(24 \%)$, в меньшей степени - для классов $A, B$ и $C 2(21-22 \%)$ и ещё меньше для классов $D$ и $E(13 \%$ в низшем низшем классе).

\section{Типология населения по стилю жизни в отношении здоровья}

Факторный анализ переменных, составляющих СЖЗ, выявил четыре латентных фактора (см. табл. П1), объясняющих 49,6\% дисперсии. Первый из них ассоциируется с продолжительностью рабочего времени и степенью нерегулярности питания. В него также с положительной нагрузкой входит переменная занятости на вредном производстве. Второй фактор, очевидно, связан с наличием таких вредных привычек, как курение и высокое потребление алкоголя. Третий фактор направлен на соблюдение диеты и приём витаминов, а также профилактические посещения врача. Наконец, четвёртый фактор определяется интенсивностью занятий спортом и нормальной массой тела. Таким образом, основные четыре составляющие СЖЗ - это питание, отсутствие вредных привычек, профилактика и физическая активность.

Дополнительно мы рассчитали индекс риска (изменяется от 1 до 7) как сумму дихотомических показателей негативных воздействий на здоровье: нерегулярное питание, ожирение, отсутствие занятий спортом, курение, употребление более 800 г этанола в месяц для мужчин и боле 400 г для женщин, работа на вредном производстве, рабочая неделя более 45 ч.

На основе описанных выше переменных, относящихся к практикам СЖЗ, методом кластерного анализа $K$-средних были выделены восемь типов стиля жизни (см. табл. П2, П3), различающихся степенью 
негативных воздействий на здоровье согласно рассчитанному индексу, а также выраженностью различных его факторов.

Абсолютно здоровым стиль жизни можно назвать только первой группы (8,5\% выборки; средний индекс риска равен 1,17). В этой группе все занимаются спортом (в среднем 10,4 ч в месяц), никто не курит, 91\% пьёт менее 200 г чистого этанола в месяц, всего 8,5\% работают более 45 ч в неделю. В то же время здесь никто не придерживается диеты и только 7\% принимают витамины. Однако мы полагаем, что это не так важно для поддержания здоровья, так как в эту группу входит преимущественно молодёжь: 57\% менее 25 лет, 77\% не состоят в браке. Распределение по полу почти равное. Молодой возраст, очевидно, объясняет то, что более половины не имеют профессионального образования и не работают, а также оценивают своё здоровье как хорошее. Представители группы чаще всего принадлежат к среднему классу (65\%), а более четверти — к верхнему квинтилю по доходам.

Вторая группа довольно малочисленна $(5,2 \%)$, отличается от первой прежде всего тем, что две трети её представителей предпочитают принимать витамины, а треть - следовать диете. Вероятно, это объясняется тем, что, несмотря на занятия спортом, половина представителей этой группы страдают избыточным весом или ожирением. Многие $(33,6 \%)$ посещают врача не из-за болезни, поэтому этот стиль жизни можно назвать профилактическим (индекс риска - 1,34). В этой группе распределение по возрасту близко к среднему по выборке (но несколько выше, чем в среднем, доля возрастов до 25 лет и ниже - старше 45 лет); две трети - женщины; 44\% не работают; выше, чем в других группах, доля управляющих $(4,9 \%)$ и специалистов (18\%). Высшее образование имеют $40 \%$; по доходам $36 \%$ принадлежат к верхней квинтильной группе, 70\% - к среднему классу (в том числе 33\% к среднему среднему), а 3\% - к высшему (это больше, чем в любой другой группе). Таким образом, к профилактическому стилю жизни склонны прежде всего люди, занимающие высокие социальные позиции.

Третья группа (19\%) характеризуется тем, что её представители хотя и не курят, употребляют мало алкоголя, регулярно питаются, однако совсем не занимаются спортом и три четверти имеют избыточный вес (в том числе 35,5\% - ожирение). К такому стилю жизни склонны прежде всего неработающие пожилые женщины (женщин - 75\%; 64\% - старше 54 лет; 78\% не работают). В этой группе также очень низкая профилактика: никто не следует диете; $12,6 \%$ принимают витамины или другие пищевые добавки; $10 \%$ посещают врача не в случае заболевания (индекс риска - 2,34). Таким образом, это nacсивный стиль жизни. Более четверти оценивают своё здоровье как плохое. Представители этой группы имеют самый низкий социальный статус: $65 \%$ принадлежат к низшему классу (в том числе $40 \%-$ к классу $E)$.

Представители четвёртой, самой многочисленной группы $(27,7 \%)$ также не имеют вредных привычек (курение и алкоголь), не занимаются спортом, однако они питаются менее регулярно и не только дома, среди них более половины имеют нормальный вес, чаще принимают витамины, придерживаются диеты и ходят к врачу. В целом практики этой группы близки к средним по выборке, поэтому этот стиль жизни можно назвать умереннылм или нейтральнылм (индекс риска - 2,39). В этой группе женщин $73 \%$, однако по остальным социально-экономическим характеристикам распределения близки к средним по всей выборке.

Пятая группа - самая малочисленная (2,8\%). Её стиль жизни весьма противоречив: все занимаются спортом и курят, 34\% потребляют 200-800 г этанола в месяц (но не более 800 г), большинство имеют нормальный вес (60\%), не очень склонны к домашнему и регулярному питанию, каждый пятый принимает пищевые добавки и посещает врача с профилактической целью. Этот стиль жизни можно назвать умеренным риском (индекс риска - 2,52). Среди склонных к нему - 72,4\% мужчин; 74\% — в возрасте 18-44 года; 53,5\% оценивают своё здоровье как хорошее. Социальный статус этих людей выше средне- 
го: $68 \%$ относятся к среднему классу, $34,7 \%$ - к верхнему квинтилю по доходам. Таким образом, это стиль жизни мужчин среднего возраста и среднего класса.

Риски для здоровья шестой группы (8\%) прежде всего обусловлены работой на вредном производстве $(41,7 \%)$. Видимо, с этим фактором связаны и профилактические обследования у врача почти половины состава. В этой группе также самая продолжительная рабочая неделя (у $18 \%-45-60$ ч, у 9,7\% более 60 ч). Среди представителей группы никто не занимается спортом, 40\% страдают ожирением (больше, чем в любой другой группе), мало кто принимает витамины $(9 \%)$ и тем более придерживается диеты $(1,8 \%)$. Чуть менее трети курят, хотя 80\% употребляют очень мало алкоголя (менее 200 г этанола в месяц). Таким образом, этот стиль жизни связан с негативным влиянием работы; индекс риска здесь выше трёх. В этой группе распределение по полу почти такое же, как в среднем по выборке (мужчин $43 \%)$, но более представлены средние группы по возрасту (56\% - 35-54 года). Более половины имеют среднее профессиональное образование (это выше, чем в любой другой группе), все работают, причём большинство являются либо служащими (36,5\%), либо квалифицированными рабочими (31,3\%). Поэтому неудивительно, что здесь больше всего представителей низшего среднего класса (35,3\%), хотя их доходы нельзя назвать низкими.

Седьмая группа составляет более пятой части выборки (21,9\%), индекс риска довольно высок $(3,5)$, а доминирующие негативные факторы - курение и отсутствие физической активности. В то же время половина представителей группы не страдают лишним весом, три четверти регулярно питаются, 64\% пьют совсем мало алкогольных напитков, а остальные - умеренно. Представителей этого стиля жизни можно назвать курильщикками. В этой группе 72,4\% мужчин, 45\% — в возрасте $25-44$ года, 48\% со средним профессиональным образованием, не работают 34,4\%, а 30,6\% работают как квалифицированные рабочие. Доходы ниже средних по выборке, $51 \%$ принадлежат к низшему классу (в том числе $23,2 \%$ - к классу $E$ ).

Наконец, последняя - восьмая - группа (6,8\%) имеет самый нездоровый стиль жизни (индекс риска равен 4,25). Главный фактор риска — чрезмерное, более 800 г в месяц, потребление алкоголя. Кроме того, 75\% курят, 88\% не занимаются спортом, 43\% нерегулярно питаются (это выше, чем в любой другой группе), только 9,2\% принимают витамины, 14\% посещают врача с профилактической целью. В этой группе 89,8\% - мужчины, 48\% - в возрасте 35-54 года, среди занятых - большинство квалифицированные рабочие, чьи доходы ниже средних, $53 \%$ относятся к низшему классу (в том числе $27 \%$, то есть выше, чем в любой другой группе, к классу $E$ ).

Была обнаружена значимая, хотя и не прямая, взаимосвязь (по критерию хи-квадрат) между социальным статусом и стилем жизни в отношении здоровья. Так, представители высшего класса более, чем средний россиянин, склонны выбирать профилактический стиль жизни (11,2\% по сравнению с 5,2\%), а также здоровый образ жизни (11,3\% против 8,5\%). Представители высшего среднего и среднего среднего классов также несколько больше склонны к этим типам. Низший средний класс - это практически средний россиянин по выбору стилей жизни. В низшем классе $(D)$, напротив, меньше склонность к двум первым стилям жизни и выше - к стилю жизни курильщиков и нездоровому стилю жизни. Класс $E$ (низший низший) чаще выбирает пассивный $(33,7 \%)$ стиль жизни и в меньшей степени - $\kappa y$ рильщиков и нездоровый.

\section{Факторы, влияющие на тип стиля жизни в отношении здоровья}

Для выявления факторов, влияющих на выбор СЖЗ, были оценены две мультиномиальные регрессии. В первой мы использовали, помимо других переменных, отдельные характеристики, связанные с социальным статусом: доходы, образование и профессиональный статус (см. табл. П4). Во второй модели 
вместо них были включены дамми, соответствующие построенной нами социальной стратификации, с базовой категорией «класс $C 2$ (низший средний)» как наиболее массовой и близкой к среднероссийским показателям (см. табл. П5). Существенное сокращение выборки в моделях (до 45 тыс. в первом случае и 46 тыс. во втором) произошло за счёт включения в число регрессоров переменной «самооценка здоровья в прошлом году», поэтому в качестве альтернативы были оценены модели с аналогичной переменной для текущего года, однако в последнем случае нельзя исключить эндогенности.

Зависимая переменная - построенный выше тип стиля жизни в отношении здоровья. В качестве базовой категории взят «нейтральный» тип, во-первых, как один из двух наиболее распространённых и, во-вторых, как в целом соответствующий характеристикам, средним для всей России. Качество первой модели несколько выше, чем второй $\left(\mathrm{R}^{2}\right.$ равен 0,21 по сравнению с 0,18$)$.

В обеих моделях значимыми переменными оказались пол и возраст (квадратичная зависимость), что позволяет не опровергать гипотезу 3, а также контрольные переменные - семейный статус, количество детей и количество других взрослых в семье, уровень здоровья в прошлом году, место жительства, региональный уровень душевых доходов и региональная безработица.

Значимыми оказались также переменные уровня образования, статуса учащегося, логарифм душевого дохода и профессиональный статус в первой модели, социальный класс - во второй модели, что не опровергает гипотезу 2.

Итак, более склонными к стилю «здоровый образ жизни» по сравнению с «нейтральным» оказались мужчины по сравнению с женщинами, люди более молодые, не состоящие в браке, с хорошим здоровьем. Среди переменных социоэкономического статуса позитивное влияние оказывает высшее образование или статус учащегося, а также логарифм душевого дохода, а негативное - все профессиональные позиции по сравнению с незанятыми. В модели для социального статуса предикторами выступают принадлежность к классам $B$ и $C 1$. Кроме того, негативными значимыми факторами становятся количество своих детей и количество других взрослых в семье.

Стиль жизни «профилактический» по сравнению с «нейтральным» более характерен при прочих равных условиях также для мужчин (хотя доля женщин в этой группе выше) и для тех, в чьей семье мало других взрослых; он не характерен для людей с плохим здоровьем. С каждым годом склонность к этому стилю жизни также становится выше. Как и для предыдущей группы, позитивно влияние душевого дохода и высшего образования; статуса учащегося и всех профессиональных статусов по сравнению с незанятыми. Среди социальных классов, кроме классов $B$ и $C 1$, позитивно влияет и принадлежность к классу $A$ (в этой модели также становится значимым логарифм региональных душевых доходов).

Пассивный стиль жизни более привлекателен для людей среднего и старшего возраста и для женщин, а также для людей, состоящих в браке и имеющих детей, и менее привлекателен для людей с плохим здоровьем. Придерживающиеся его чаще проживают в регионах с более высоким уровнем безработицы и более низкими душевыми доходами, а также в сельской местности. Этот стиль жизни тоже становится более распространённым с течением времени. Значимыми негативными факторами выступают наличие высшего образования, душевой доход семьи и любой профессиональный статус по сравнению с незанятостью. Во второй модели значимо негативное влияние на принадлежность к этому стилю оказывает класс $C 1$, а значимо позитивное - классы $D$ и $E$.

К стилю жизни «умеренного риска» (ориентированный как на занятия спортом, так и на курение) склонны люди среднего возраста, из небольших семей и более богатых регионов, а также мужчины. Напротив, реже его выбирают люди с высшим образованием и с низкими доходами; по сравнению с не- 
занятыми - имеющие любой профессиональный статус, кроме неквалифицированных рабочих. Примечательно, что во второй модели ни один социальный класс не является значимым. Таким образом, на склонность к данному стилю жизни влияют прежде всего демографические характеристики (пол и возраст), а воздействие социоэкономического статуса выглядит противоречивым (позитивный эффект доходов, но негативный - образования).

Стиль жизни, связанный с влиянием на здоровье прежде всего вредного производства и продолжительности рабочего дня, типичен в большей степени для людей среднего возраста, для мужчин, людей со средней самооценкой здоровья, из регионов с низкой безработицей и не типичен для жителей Москвы и Санкт-Петербурга. В первой модели незначим душевой доход, негативно влияние высшего образования и позитивно - всех профессиональных статусов по сравнению с незанятостью. Во второй - негативное влияние всех социальных классов по сравнению с $C 2$.

Что касается курильщиков, то неудивительно, что это чаще всего мужчины и люди среднего возраста, со средней самооценкой здоровья, они чаще имеют детей и семью с небольшим количеством других взрослых, живут в более обеспеченных регионах с низким уровнем безработицы. Уровень урбанизации незначим. Популярность этого стиля жизни постепенно снижается по сравнению с 2010 г. В первой модели негативными предикторами выступают уровень образования и логарифм душевого дохода, а также профессиональный статус по сравнению с незанятостью. Во второй модели по сравнению с классом $C 2$ значимы негативное влияние классов $A, B$ и $C 1$ и позитивное - классов $D$ и $E$.

Наконец, любители большого количества алкоголя также в основном мужчины среднего возраста из семей с небольшим количеством взрослых и со средней самооценкой здоровья. Они чаще проживают в регионах с более высоким душевым доходом, но также и с более высокой безработицей. Слабое негативное влияние оказывает проживание в других населённых пунктах (по сравнению с Москвой и Санкт-Петербургом). Среди социоэкономических характеристик отмечено негативное влияние уровня образования (как высшего, так и среднего профессионального) и душевого дохода, а также любого профессионального статуса (по сравнению с отсутствием работы). Во втором варианте регрессии значимое позитивное влияние по сравнению с классом $C 2$ оказывает класс $E$, а значимое негативное классы $B$ и $C 1$. Возрастает также сила негативного влияния других, кроме Москвы и Санкт Петербурга, областных центров.

\section{Выводы}

Кластерный анализ не опроверг гипотезу о наличии широкого спектра стилей жизни между полюсами наиболее и наименее здорового в зависимости от различий основных факторов, влияющих на здоровье. Таким образом, гипотеза 1 не опровергнута: помимо двух крайних групп («здоровый» и «нездоровый» стили жизни), удалось выявить ещё шесть, различающихся как индексом риска, так и преобладающим негативным фактором воздействия на здоровье.

Регрессионный анализ показал значимое влияние социального класса на выбор стиля жизни в отношении здоровья (по сравнению с «нейтральным») при прочих равных условиях для всех стилей, кроме «умеренного риска». И хотя оценка качества второй модели несколько ниже (псевдо- $R^{2}$ равен 0,18 по сравнению с 0,21), мы полагаем, что в целом эта модель лучше интерпретируема, чем первая, где используется не дамми для социальных классов, а отдельные показатели социоэкономического статуса (образование, доход и профессиональный статус). Для высшего и высшего среднего классов (классы $A$ и $B$ ) наиболее характерны стили жизни «здоровый» и «профилактический»; для низшего среднего класса $(C 2)$ - «вредная работа», для низших классов $(D$ и $E)$ - стили «пассивный» и «курильщики», для класса $E$, кроме того, значимо высокое потребление алкоголя. Таким образом, представители выс- 
шего и средних социальных классов действительно более ориентированы на сохранение здоровья, чем представители низших классов, что позволяет не опровергнуть гипотезу 2.

Наконец, как и можно было ожидать, чаще здоровый образ жизни выбирают женщины, молодёжь, люди с высокими доходами и образованием, что подтверждает гипотезу 3.

В целом полученные результаты показали, что в России между стилем жизни в отношении здоровья и социальным классом существует достаточно тесная взаимосвязь, а это соответствует как теоретическим предположениям, так и зарубежным эмпирическим исследованиям. Однако такой вывод приводит к заключению, что склонность к здравоохранительным практикам формируется на основании габитуса и условий существования определённой социальной группы. Можно поэтому ожидать, что с повышением образования и доходов населения и соответствующим снижением доли низшего класса уменьшится число приверженцев курения и чрезмерного потребления алкоголя. Кроме того, положительный эффект в распространении таких позитивных практик, как, например, занятия спортом и правильное питание, мог бы дать рост их престижа с помощью пропаганды - через референтные группы, кинофильмы, журналы, Интернет и другие средства массовой коммуникации.

Наконец, очевидно, что одной из самых серьёзных проблем является плохое здоровье пожилых, что связано как с их низкими доходами и неудовлетворительными возможностями профилактики и лечения заболеваний, так и во многом с характерным для них пассивным образом жизни. Мы полагаем, что необходим специальный акцент социальной политики на улучшении условий жизни именно этой социальной группы, включающий как рост доходов, так и улучшение доступности медицины и возможностей для физической активности.

\section{Приложение}

Таблица П1

Повёрнутая матрица компонентов факторного анализа

\begin{tabular}{lcccc}
\hline \multicolumn{1}{c}{ Переменные } & \multicolumn{3}{c}{ Компонент } \\
& \multicolumn{1}{c}{ По } & 2 & 3 & 4 \\
\hline Степень домашнего питания & $-\mathbf{0 , 7 3 0}$ & $-0,002$ & 0,003 & 0,270 \\
Степень нерегулярности питания & $\mathbf{0 , 4 3 6}$ & 0,175 & $-0,228$ & $-0,272$ \\
Количество часов занятий спортом & $-0,025$ & $-0,070$ & 0,300 & $-\mathbf{0 , 6 1 2}$ \\
Объём потребления алкоголя & $-0,025$ & $\mathbf{0 , 8 2 0}$ & 0,063 & 0,005 \\
Объём курения & 0,146 & $\mathbf{0 , 7 4 1}$ & $-0,140$ & 0,008 \\
Индекс массы тела & $-0,033$ & $-0,029$ & 0,136 & $\mathbf{0 , 7 6 6}$ \\
Приём витаминов и т. п. & $-0,064$ & $-0,035$ & $\mathbf{0 , 6 8 1}$ & $-0,131$ \\
Диета за последние 12 мес. & $-0,041$ & 0,034 & $\mathbf{0 , 6 5 8}$ & 0,088 \\
Профилактическое посещение врача & 0,316 & $-0,161$ & 0,412 & $-0,010$ \\
Работа на вредном производстве (для незанятых $=0)$ & $\mathbf{0 , 5 0 0}$ & $-0,029$ & 0,160 & 0,247 \\
Количество часов работы в неделю (для незанятых $=0)$ & $\mathbf{0 , 7 4 8}$ & 0,125 & $-0,066$ & 0,109 \\
\hline
\end{tabular}


Таблиия П2

Характеристика кластеров по стилю жизни в отношении здоровья (СЖ3).

RLMS-HSE, 2010-2014 гг., население 14+, \%

\begin{tabular}{|c|c|c|c|c|c|c|c|c|c|}
\hline \multirow[b]{2}{*}{$\begin{array}{l}\text { Переменные - } \\
\text { компоненты СЖ3 }\end{array}$} & \multicolumn{8}{|c|}{ СЖЗ } & \multirow[b]{2}{*}{$\begin{array}{l}\stackrel{0}{0} \\
.0 \\
\ddot{n}\end{array}$} \\
\hline & 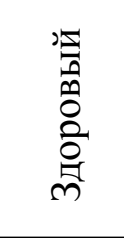 & 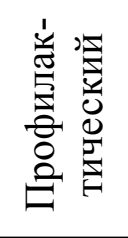 & 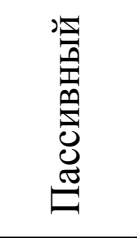 & 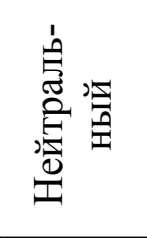 & 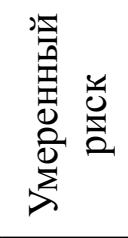 & 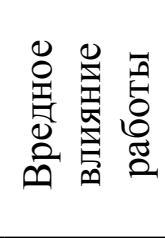 & 总总 & 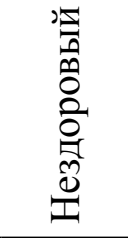 & \\
\hline \multicolumn{10}{|l|}{ Тип питания: } \\
\hline только дома & 36,9 & 45,9 & 96,7 & 40,6 & 35,9 & 20,7 & 54,8 & 54,7 & 55,5 \\
\hline дома и вне дома & 58,6 & 51,2 & 2,6 & 54,8 & 60,5 & 76,0 & 42,1 & 41,8 & 41,4 \\
\hline только вне дома & 4,4 & 2,9 & 0,7 & 4,6 & 3,6 & 3,2 & 3,1 & 3,5 & 3,0 \\
\hline Регулярное питание & 77,4 & 83,5 & 94,8 & 73,7 & 73,1 & 75,0 & 74,2 & 66,8 & 79,4 \\
\hline Ожирение & 0,0 & 27,3 & 35,5 & 17,8 & 11,4 & 40,1 & 13,2 & 16,3 & 20,8 \\
\hline Избыточный вес & 21,9 & 22,5 & 39,2 & 27,1 & 28,5 & 33,3 & 31,3 & 32,7 & 30,5 \\
\hline Нормальный вес & 78,1 & 50,3 & 25,3 & 55,0 & 60,1 & 26,6 & 55,5 & 51,0 & 48,7 \\
\hline Не занимается спортом & 0,0 & 0,0 & 100,0 & 100,0 & 0,0 & 100,0 & 100,0 & 88,2 & 82,6 \\
\hline Витамины и т. д. & 7,2 & 67,5 & 12,6 & 25,0 & 21,1 & 8,9 & 11,8 & 9,2 & 18,1 \\
\hline Диета & 0,1 & 35,4 & 0,0 & 15,6 & 10,6 & 1,8 & 4,4 & 2,7 & 7,8 \\
\hline Не курит & 100,0 & 100,0 & 100,0 & 100,0 & 0,0 & 70,4 & 0,0 & 25,1 & 68,6 \\
\hline \multicolumn{10}{|l|}{ Объём этанола в месяц: } \\
\hline менее 200 г & 90,8 & 89,2 & 93,9 & 90,6 & 66,3 & 80,2 & 63,8 & 0,0 & 77,6 \\
\hline $200-400$ г & 6,1 & 7,0 & 4,1 & 6,3 & 19,9 & 13,3 & 20,6 & 0,0 & 9,5 \\
\hline $400-800$ г & 3,0 & 3,9 & 2,0 & 3,1 & 13,8 & 6,6 & 15,6 & 0,0 & 6,0 \\
\hline 800 г и более & 0,0 & 0,0 & 0,0 & 0,0 & 0,0 & 0,0 & 0,0 & 100,0 & 6,8 \\
\hline Вредное производство & 6,2 & 9,0 & 0,5 & 4,5 & 11,3 & 41,7 & 3,8 & 8,9 & 7,4 \\
\hline Профобследования врача & 23,8 & 33,6 & 10,2 & 18,4 & 22,1 & 48,5 & 12,6 & 14,0 & 19,1 \\
\hline Не работает & 57,6 & 46,8 & 78,2 & 43,3 & 35,6 & 0,0 & 36,0 & 39,1 & 45,7 \\
\hline Работает & 42,4 & 53,2 & 21,8 & 56,7 & 64,4 & 100,0 & 64,0 & 60,9 & 54,3 \\
\hline \multicolumn{10}{|l|}{ Рабочая неделя (ч): } \\
\hline до 20 & 5,1 & 7,3 & 4,0 & 4,6 & 7,4 & 2,7 & 5,8 & 7,4 & 5,0 \\
\hline $20-45$ & 29,4 & 37,5 & 15,5 & 41,0 & 42,6 & 69,3 & 41,3 & 40,1 & 37,2 \\
\hline $45-60$ & 6,7 & 7,7 & 2,4 & 8,4 & 13,8 & 18,3 & 13,2 & 11,6 & 9,3 \\
\hline более 60 & 1,8 & 2,4 & 0,3 & 2,6 & 6,6 & 9,7 & 5,8 & 6,1 & 3,7 \\
\hline $\begin{array}{l}\text { Количество сигарет в месяц } \\
\text { (шт.) }\end{array}$ & 0,00 & 0,00 & 0,00 & 0,00 & 13,58 & 4,37 & 15,94 & 14,69 & 5,10 \\
\hline $\begin{array}{l}\text { Продолжительность занятий } \\
\text { спортом (ч в месяц) }\end{array}$ & 10,4 & 11,0 & 0,0 & 0,0 & 9,4 & 0,0 & 0,0 & 1,1 & 1,8 \\
\hline Индекс риска & 1,17 & 1,34 & 2,34 & 2,39 & 2,52 & 3,17 & 3,50 & 4,25 & 2,60 \\
\hline Количество респондентов (чел.) & 5760 & 3339 & 15433 & 14385 & 2250 & 6521 & 13632 & 3365 & 64745 \\
\hline Процент от выборки & 8,9 & 5,2 & 23,8 & 22,2 & 3,5 & 10,1 & 21,1 & 5,2 & 100,0 \\
\hline
\end{tabular}


Характеристика типов СЖЗ по социально-экономическим показателям. RLMS-HSE, 2010-2014 гг., население 14+, \%

\begin{tabular}{|c|c|c|c|c|c|c|c|c|c|}
\hline \multirow[b]{2}{*}{$\begin{array}{c}\text { Социально-экономические } \\
\text { показатели }\end{array}$} & \multicolumn{8}{|c|}{ СЖ3 } & \multirow[b]{2}{*}{$\begin{array}{l}\stackrel{0}{0} \\
\stackrel{0}{0}\end{array}$} \\
\hline & 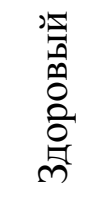 & 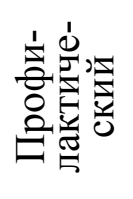 & 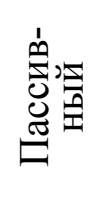 & 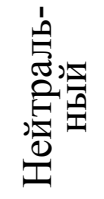 & 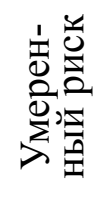 & 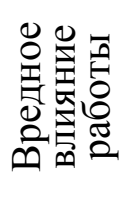 & 总总 & 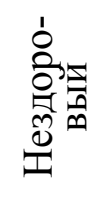 & \\
\hline Мужчины & 54,9 & 34,5 & 24,5 & 26,9 & 72,4 & 43,1 & 72,4 & 89,8 & 46,0 \\
\hline В браке & 33,4 & 48,3 & 58,0 & 56,3 & 54,5 & 74,1 & 69,6 & 71,2 & 59,5 \\
\hline \multicolumn{10}{|l|}{ Возраст (полных лет): } \\
\hline $13-17$ & 29,4 & 15,9 & 1,0 & 5,6 & 8,0 & 0,1 & 0,8 & 0,5 & 5,5 \\
\hline $18-24$ & 27,7 & 17,2 & 4,1 & 15,3 & 26,6 & 6,3 & 12,9 & 7,7 & 12,9 \\
\hline $25-34$ & 17,2 & 19,0 & 8,4 & 19,9 & 27,3 & 20,8 & 24,6 & 21,3 & 18,8 \\
\hline $35-44$ & 10,1 & 14,8 & 9,0 & 16,7 & 20,0 & 25,8 & 22,1 & 25,1 & 17,1 \\
\hline $45-54$ & 6,4 & 11,6 & 13,6 & 16,6 & 10,6 & 29,7 & 19,3 & 23,2 & 16,8 \\
\hline $55-64$ & 5,0 & 12,8 & 24,0 & 12,0 & 6,0 & 14,9 & 14,3 & 14,5 & 14,5 \\
\hline$>=65$ & 4,2 & 8,7 & 39,9 & 13,9 & 1,6 & 2,3 & 6,0 & 7,8 & 14,3 \\
\hline \multicolumn{10}{|l|}{ Социальный класс (по главе семьи): } \\
\hline$A$ (высший) & 1,8 & 2,9 & 0,9 & 1,3 & 1,9 & 1,6 & 1,0 & 1,4 & 1,3 \\
\hline$B$ (высший средний) & 10,5 & 11,9 & 4,8 & 7,6 & 9,8 & 8,6 & 5,8 & 6,5 & 7,2 \\
\hline C1 (средний средний) & 27,8 & 32,9 & 11,8 & 20,0 & 28,2 & 21,4 & 14,5 & 15,3 & 18,6 \\
\hline C2 (низший средний) & 27,8 & 24,8 & 17,5 & 27,7 & 30,2 & 35,3 & 26,9 & 23,9 & 25,9 \\
\hline$D$ (низший) & 19,9 & 16,5 & 25,0 & 23,4 & 19,6 & 24,9 & 28,6 & 25,9 & 24,4 \\
\hline$E$ (низший низший) & 12,2 & 11,0 & 40,1 & 20,0 & 10,4 & 8,1 & 23,2 & 27,0 & 22,7 \\
\hline \multicolumn{10}{|l|}{ Квинтильные группы: } \\
\hline 1 (самые бедные) & 16,0 & 8,7 & 18,2 & 17,2 & 13,0 & 13,5 & 22,2 & 22,7 & 17,9 \\
\hline 2 & 18,3 & 12,6 & 22,3 & 20,1 & 14,8 & 17,3 & 19,5 & 17,8 & 19,3 \\
\hline 3 & 18,5 & 17,5 & 25,4 & 21,1 & 15,9 & 19,6 & 18,7 & 16,8 & 20,5 \\
\hline 4 & 20,5 & 25,3 & 20,6 & 20,2 & 21,6 & 23,9 & 19,1 & 19,3 & 20,6 \\
\hline 5 (самые богатые) & 26,6 & 36,0 & 13,4 & 21,4 & 34,7 & 25,6 & 20,4 & 23,5 & 21,7 \\
\hline \multicolumn{10}{|l|}{ Образование: } \\
\hline среднее и ниже & 53,2 & 34,3 & 41,8 & 34,8 & 37,6 & 20,9 & 37,6 & 39,1 & 37,5 \\
\hline профессиональное среднее & 18,3 & 25,9 & 39,3 & 37,8 & 35,7 & 53,5 & 48,1 & 45,5 & 39,8 \\
\hline высшее & 28,5 & 39,9 & 18,9 & 27,4 & 26,8 & 25,5 & 14,3 & 15,5 & 22,7 \\
\hline \multicolumn{10}{|l|}{ Профессиональный статус: } \\
\hline не работают & 56,7 & 44,3 & 75,2 & 40,1 & 34,5 & 0 & 34,4 & 38,5 & 43,7 \\
\hline военные & 0,6 & 0,6 & 0,0 & 0,1 & 1,5 & 0,7 & 0,2 & 0,4 & 0,3 \\
\hline управляющие & 2,9 & 4,9 & 1,3 & 2,9 & 3,9 & 4,0 & 2,9 & 4,1 & 2,9 \\
\hline $\begin{array}{l}\text { специалисты с высшим } \\
\text { образованием }\end{array}$ & 13,1 & 18,1 & 4,8 & 13,3 & 10,0 & 18,8 & 4,8 & 4,6 & 9,8 \\
\hline служащие без высшего образования & 16,9 & 23,6 & 10,0 & 26,2 & 23,5 & 36,5 & 17,2 & 11,2 & 20,0 \\
\hline квалифицированные рабочие & 6,7 & 5,8 & 4,6 & 11,4 & 20,6 & 31,3 & 30,6 & 31,8 & 16,9 \\
\hline
\end{tabular}




\begin{tabular}{|c|c|c|c|c|c|c|c|c|c|}
\hline \multirow[b]{2}{*}{$\begin{array}{c}\text { Социально-экономические } \\
\text { показатели }\end{array}$} & \multicolumn{8}{|c|}{ СЖЗ } & \multirow[b]{2}{*}{ : } \\
\hline & 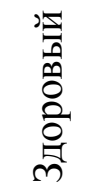 & 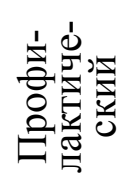 & 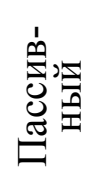 & 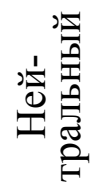 & 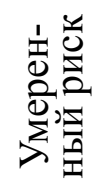 & 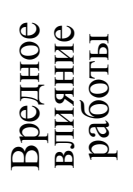 & 总总 & 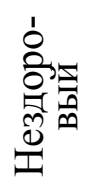 & \\
\hline неквалифицированные рабочие & 3,1 & 2,8 & 4,1 & 5,9 & 6,0 & 8,7 & 9,9 & 9,3 & 6,5 \\
\hline \multicolumn{10}{|l|}{ Самооценка здоровья: } \\
\hline плохое & 2,4 & 7,3 & 25,3 & 13,0 & 4,1 & 4,9 & 9,3 & 9,7 & 12,2 \\
\hline среднее & 36,0 & 51,3 & 53,7 & 49,6 & 42,3 & 58,5 & 53,7 & 57,4 & 51,2 \\
\hline хорошее & 61,6 & 41,4 & 21,0 & 37,4 & 53,5 & 36,6 & 37,0 & 32,9 & 36,6 \\
\hline
\end{tabular}

Мультиномиальная логистическая регрессия

Таблицуа П4 (зависимая переменная — «тип СЖЗ»; базовая категория — «нейтральный» тип)

\begin{tabular}{|c|c|c|c|c|c|c|c|}
\hline $\begin{array}{c}\text { Независимые } \\
\text { переменные }\end{array}$ & $\begin{array}{c}\text { Здоровый } \\
\text { стиль } \\
\text { жизни }\end{array}$ & $\begin{array}{l}\text { Профилак- } \\
\text { тический }\end{array}$ & $\begin{array}{l}\text { Пас- } \\
\text { сивный }\end{array}$ & $\begin{array}{l}\text { Умерен- } \\
\text { ный риск }\end{array}$ & $\begin{array}{c}\text { Вредное } \\
\text { влияние } \\
\text { работы }\end{array}$ & $\begin{array}{c}\text { Куриль- } \\
\text { щики }\end{array}$ & $\begin{array}{c}\text { Нездоро- } \\
\text { вый стиль } \\
\text { жизни }\end{array}$ \\
\hline$\frac{\text { Boзраст }}{10}$ & $-0,920^{* * *}$ & $-0,233^{*}$ & $0,767^{* * *}$ & $0,686^{* * *}$ & $1,494^{* * *}$ & $1,253^{* * *}$ & $2,181^{* * *}$ \\
\hline$\frac{\text { Bозраст }^{2}}{100}$ & $0,0775^{* * *}$ & 0,0197 & $-0,0240^{* * *}$ & $-0,119^{* * *}$ & $-0,139^{* * *}$ & $-0,139^{* * *}$ & $-0,228^{* * *}$ \\
\hline Мужской пол & $1,191^{* * *}$ & $0,441^{* * *}$ & $-0,208^{* * *}$ & $2,092^{* * *}$ & $0,544^{* * *}$ & $1,964^{* * *}$ & $3,267^{* * *}$ \\
\hline В браке & $-0,234^{* * *}$ & $-0,0549$ & $-0,248^{* * *}$ & 0,0295 & 0,0935 & 0,0741 & 0,0517 \\
\hline $\begin{array}{l}\text { Среднее про- } \\
\text { фессиональное } \\
\text { образование }\end{array}$ & $-0,0680$ & 0,0260 & $-0,0736$ & 0,0354 & 0,0996 & $-0,126^{*}$ & $-0,301^{* * *}$ \\
\hline $\begin{array}{l}\text { Высшее } \\
\text { образованиие }\end{array}$ & $0,371^{* * *}$ & $0,299^{* *}$ & $-0,341^{* * *}$ & $-0,272^{*}$ & $-0,477^{* * *}$ & $-0,865^{* * *}$ & $-0,901^{* * *}$ \\
\hline Учится & $0,0741^{* * *}$ & $0,0616^{*}$ & $-0,173^{* * *}$ & $-0,0262$ & $-0,0527$ & $-0,241^{* * *}$ & $-0,249^{* * *}$ \\
\hline $\begin{array}{l}\text { Количество } \\
\text { детей }\end{array}$ & $-0,101$ & $-0,0505$ & $0,238^{* * *}$ & 0,0305 & 0,0746 & $0,112^{* *}$ & $-0,111$ \\
\hline $\begin{array}{l}\text { Количе- } \\
\text { ство других } \\
\text { взрослых }\end{array}$ & $-0,0351^{*}$ & $-0,122^{* * *}$ & $-0,000839$ & $-0,0938^{* *}$ & 0,0213 & $-0,0560^{* * *}$ & $-0,087^{* * *}$ \\
\hline $\begin{array}{l}\text { Лог душевого } \\
\text { дохода }\end{array}$ & $0,223^{* * *}$ & $0,545^{* * *}$ & $-0,132^{* * *}$ & $0,256^{* *}$ & $-0,0217$ & $-0,156^{* * *}$ & $-0,204^{* * *}$ \\
\hline $\begin{array}{l}\text { Руководите- } \\
\text { ли (база - } \\
\text { незанятые) }\end{array}$ & $-0,445^{* *}$ & $-0,379^{*}$ & $-1,385^{* * *}$ & $-0,613^{* *}$ & $4,181^{* * *}$ & $-0,837^{* * *}$ & $-0,710^{* * *}$ \\
\hline Специалисты & $-0,359^{* * *}$ & $-0,362^{* * *}$ & $-1,450^{* * *}$ & $-0,785^{* * *}$ & $4,601^{* * *}$ & $-1,088^{* * *}$ & $-1,190^{* * *}$ \\
\hline Служащие & $-0,600^{* * *}$ & $-0,550^{* * *}$ & $-1,338^{* * *}$ & $-0,433^{* * *}$ & $4,475^{* * *}$ & $-0,566^{* * *}$ & $-0,804^{* * *}$ \\
\hline $\begin{array}{l}\text { Квалифициро- } \\
\text { ванные рабочие }\end{array}$ & $-1,064^{* * *}$ & $-0,937^{* * *}$ & $-1,390^{* * *}$ & $-0,776^{* * *}$ & $4,593^{* * *}$ & $-0,409^{* * *}$ & $-0,753^{* * *}$ \\
\hline $\begin{array}{l}\text { Неквалифи- } \\
\text { цированные } \\
\text { рабочие }\end{array}$ & $-0,711^{* * *}$ & $-1,072^{* * *}$ & $-1,118^{* * *}$ & $-0,379^{*}$ & $4,222^{* * *}$ & $-0,180^{*}$ & $-0,561^{* * *}$ \\
\hline
\end{tabular}


Таблица П4. Окончание

\begin{tabular}{|c|c|c|c|c|c|c|c|}
\hline $\begin{array}{l}\text { Независимые } \\
\text { переменные }\end{array}$ & $\begin{array}{c}\text { Здоровый } \\
\text { стиль } \\
\text { жизни }\end{array}$ & $\begin{array}{l}\text { Профилак- } \\
\text { тический }\end{array}$ & $\begin{array}{c}\text { Пас- } \\
\text { сивный }\end{array}$ & $\begin{array}{l}\text { Умерен- } \\
\text { ный риск }\end{array}$ & $\begin{array}{c}\text { Вредное } \\
\text { влияние } \\
\text { работы }\end{array}$ & $\begin{array}{c}\text { Куриль- } \\
\text { щики }\end{array}$ & $\begin{array}{c}\text { Нездоро- } \\
\text { вый стиль } \\
\text { жизни }\end{array}$ \\
\hline $\begin{array}{l}\text { Плохое здоро- } \\
\text { вье в прошлом } \\
\text { году }\end{array}$ & $-0,956^{* * *}$ & $-0,475^{* * *}$ & $-0,332^{* * *}$ & $-0,225$ & $-0,312^{* * *}$ & $-0,256^{* * *}$ & $-0,511^{* * *}$ \\
\hline $\begin{array}{l}\text { Хорошее здоро- } \\
\text { вье в прошлом } \\
\text { году }\end{array}$ & $0,157^{* *}$ & -0.126 & 0,00764 & $-0,00981$ & $-0,154^{* *}$ & $-0,289^{* * *}$ & $-0,352^{* * *}$ \\
\hline $\begin{array}{l}\text { Безработица в } \\
\text { регионе }\end{array}$ & $-0,0449^{*}$ & $0,0508^{*}$ & $0,0345^{* *}$ & 0,0285 & $-0,0514^{* *}$ & $-0,0454^{* *}$ & $0,137^{* * *}$ \\
\hline $\begin{array}{l}\text { Логарифм } \\
\text { региональных } \\
\text { доходов }\end{array}$ & $0,348^{*}$ & $0,862^{* * *}$ & $-0,289^{* *}$ & $1,594^{* * *}$ & 0,157 & $0,561^{* * *}$ & $0,943^{* * *}$ \\
\hline 2011 г. & $-0,0340$ & $0,169^{*}$ & $0,236^{* * *}$ & 0,0729 & 0,0318 & $-0,0414$ & $-0,0384$ \\
\hline 2012 г. & $-0,0884$ & $0,234^{*}$ & $0,198^{* * *}$ & 0,163 & $-0,0838$ & $-0,162^{* *}$ & 0,00055 \\
\hline 2013 г. & 0,112 & $0,376^{* * *}$ & $0,163^{* *}$ & $-0,00427$ & $-0,138^{*}$ & $-0,189^{* * *}$ & 0,0377 \\
\hline 2014 г. & 0,103 & $0,397^{* * *}$ & $0,135^{*}$ & 0,0493 & $-0,167^{*}$ & $-0,270^{* * *}$ & $-0,226^{*}$ \\
\hline $\begin{array}{l}\text { Областной } \\
\text { центр (база - } \\
\text { Москва и Санкт } \\
\text { Петербург) }\end{array}$ & 0,0751 & $0,352^{*}$ & $-0,174$ & 0,141 & $0,531^{* * *}$ & 0,0161 & $-0,457^{*}$ \\
\hline Город & 0,0394 & 0,198 & $-0,0983$ & 0,210 & $0,537^{* * *}$ & 0,141 & $-0,403^{*}$ \\
\hline Посёлок & $-0,222$ & 0,0642 & 0,215 & $-0,241$ & 0,298 & 0,0319 & $-0,203$ \\
\hline Село & 0,225 & 0,0800 & $0,351^{* *}$ & $-0,0675$ & $0,801^{* * *}$ & 0,235 & $-0,501^{*}$ \\
\hline Константа & $-4,513^{* *}$ & $-15,28^{* * *}$ & 1,481 & $-21,97^{* * *}$ & $-10,09^{* * *}$ & $-6,546^{* * *}$ & $-4,79^{* * *}$ \\
\hline$N$ & 45001 & & & & & & \\
\hline Wald chi2(189) & 11570,74 & & & & & & \\
\hline Prob $>$ chi 2 & 0,0000 & & & & & & \\
\hline $\begin{array}{l}\text { Log pseudolike- } \\
\text { lihood }\end{array}$ & $-65446,623$ & & & & & & \\
\hline Pseudo R2 & 0,2140 & & & & & & \\
\hline
\end{tabular}

${ }^{*} \mathrm{p}<0,05$.

${ }^{* *} \mathrm{p}<0,01$

${ }^{* * *} \mathrm{p}<0,001$. 
Таблища П5

Мультиномиальная логистическая регрессия

(зависимая переменная - «тип СЖЗ»;

базовая категория - «нейтральный» тип с включением типа социального класса)

\begin{tabular}{|c|c|c|c|c|c|c|c|}
\hline $\begin{array}{c}\text { Независимые } \\
\text { переменные }\end{array}$ & $\begin{array}{c}\text { 3доровый } \\
\text { стиль } \\
\text { жизни } \\
\end{array}$ & $\begin{array}{l}\text { Профилак- } \\
\text { тический }\end{array}$ & $\begin{array}{c}\text { Пассив- } \\
\text { ный }\end{array}$ & $\begin{array}{l}\text { Умерен- } \\
\text { ный риск }\end{array}$ & $\begin{array}{c}\text { Вредное } \\
\text { влияние } \\
\text { работы } \\
\end{array}$ & $\begin{array}{c}\text { Куриль- } \\
\text { щики }\end{array}$ & $\begin{array}{c}\text { Нездоро- } \\
\text { вый стиль } \\
\text { жизни } \\
\end{array}$ \\
\hline$\frac{\text { Возраст }}{10}$ & $-1,213^{* * *}$ & $-0,537^{* * *}$ & $0,254^{* * *}$ & $0,387^{*}$ & $2,748^{* * *}$ & $1,049^{* * *}$ & $1,859^{* * *}$ \\
\hline$\frac{\text { BoзpacT }^{2}}{100}$ & $0,115^{* * *}$ & $0,0574^{* * *}$ & $0,0370^{* * *}$ & $-0,0830^{* * *}$ & $-0,295^{* * *}$ & $-0,117^{* * *}$ & $-0,193^{* * *}$ \\
\hline Мужской пол & $1,060^{* * *}$ & $0,349^{* * *}$ & $-0,216^{* * *}$ & $2,024^{* * *}$ & $0,632^{* * *}$ & $2,054^{* * *}$ & $3,329^{* * *}$ \\
\hline В браке & $-0.261^{* * *}$ & $-0,0170$ & $0,218^{* * *}$ & $-0,0187$ & $0,110^{*}$ & 0,0463 & 0,00342 \\
\hline $\begin{array}{l}\text { Среднее } \\
\text { профес- } \\
\text { сиональное } \\
\text { образование }\end{array}$ & $0,0885^{* * *}$ & $0,0643^{* *}$ & $-0,0905^{* *}$ & 0,0186 & $-0,0416$ & $-0,166^{* * *}$ & $-0,162^{* *}$ \\
\hline $\begin{array}{l}\text { Высшее } \\
\text { образование }\end{array}$ & $-0,155^{* *}$ & $-0,0888$ & $0,231^{* * *}$ & $-0,0464$ & 0,0156 & $0,124^{* * *}$ & $-0,0946$ \\
\hline Учится & $-0,0455^{* *}$ & $-0,184^{* * *}$ & $0,0577^{* * *}$ & $-0,0926^{* *}$ & 0,00104 & $-0,00426$ & $-0,0330$ \\
\hline $\begin{array}{l}\text { Класс } A \\
\text { (база - класс } \\
C 2)\end{array}$ & 0,247 & $0,817^{* * *}$ & $-0,115$ & 0,0194 & $-0,379^{*}$ & $-0,421^{*}$ & 0,137 \\
\hline Класс $B$ & $0,454^{* * *}$ & $0,446^{* * *}$ & $-0,172^{*}$ & 0,0932 & $-0,322^{* * *}$ & $-0,519^{* * *}$ & $-0,346^{* *}$ \\
\hline Класс $C 1$ & $0,438^{* * *}$ & $0,478^{* * *}$ & $-0,283^{* * *}$ & 0,00531 & $-0,322^{* * *}$ & $-0,460^{* * *}$ & $-0,351^{* * *}$ \\
\hline Класс $D$ & 0,00288 & $-0,0864$ & $0,265^{* * *}$ & $-0,104$ & $-0,159^{* *}$ & $0,207^{* * *}$ & 0,146 \\
\hline Класс $E$ & 0,0480 & $-0,204^{*}$ & $0,593^{* * *}$ & $-0,0298$ & $-0,743^{* * *}$ & $0,603^{* * *}$ & $0,801^{* * *}$ \\
\hline $\begin{array}{l}\text { Плохое здо- } \\
\text { ровье в про- } \\
\text { шлом году }\end{array}$ & $-0,839^{* * *}$ & $-0,418^{* * *}$ & $-0,129^{*}$ & $-0,0853$ & $-0,702^{* * *}$ & $-0,166^{*}$ & $-0,354^{* * *}$ \\
\hline $\begin{array}{l}\text { Хорошее здо- } \\
\text { ровье в про- } \\
\text { шлом году }\end{array}$ & $0,156^{* *}$ & $-0,151^{*}$ & $-0,0708$ & $-0,0674$ & $-0,182^{* * *}$ & $-0,349^{* * *}$ & $-0,422^{* * *}$ \\
\hline $\begin{array}{l}\text { Безработица в } \\
\text { регионе }\end{array}$ & $-0,0292$ & $0,0517^{*}$ & $0,0664^{* * *}$ & 0,0228 & $-0,0875^{* * *}$ & $-0,0445^{* *}$ & $0,152^{* * *}$ \\
\hline $\begin{array}{l}\text { Логарифм } \\
\text { региональных } \\
\text { доходов }\end{array}$ & $0,315^{*}$ & $1,100^{* * *}$ & $-0,377^{* * *}$ & $1,634^{* * *}$ & 0,199 & $0,539^{* * *}$ & $0,892^{* * *}$ \\
\hline 2011 г. & 0,00389 & $0,244^{* *}$ & $0,282^{* * *}$ & 0,0812 & 0,00429 & $-0,0303$ & $-0,0411$ \\
\hline 2012 г. & $-0,0188$ & $0,322^{* * *}$ & $0,290^{* * *}$ & 0,170 & $-0,182^{* *}$ & $-0,173^{* *}$ & $-0,0163$ \\
\hline 2013 г. & $0,192^{* *}$ & $0,446^{* * *}$ & $0,254^{* * *}$ & 0,0162 & $-0,212^{* * *}$ & $-0,187^{* * *}$ & 0,0210 \\
\hline 2014 г. & $0,156^{*}$ & $0,445^{* * *}$ & $0,221^{* * *}$ & 0,0411 & $-0,278^{* * *}$ & $-0,265^{* * *}$ & $-0,203^{*}$ \\
\hline $\begin{array}{l}\text { Областной } \\
\text { центр (база - } \\
\text { Москва } \\
\text { и Санкт } \\
\text { Петербург) }\end{array}$ & $-0,0624$ & $0,329^{*}$ & $-0,453^{* * *}$ & 0,122 & $0,803^{* * *}$ & 0,0190 & $-0,557^{* *}$ \\
\hline Город & $-0,121$ & 0,131 & $-0,376^{* * *}$ & 0,167 & $0,848^{* * *}$ & 0,177 & $-0,489^{*}$ \\
\hline Посёлок & $-0,391^{*}$ & $-0,0156$ & 0,0233 & $-0,218$ & $0,570^{* * *}$ & 0,116 & $-0,136$ \\
\hline
\end{tabular}


Таблица П5. Окончание

\begin{tabular}{lccccccc}
\hline $\begin{array}{c}\text { Независимые } \\
\text { переменные }\end{array}$ & $\begin{array}{c}\text { Здоровый } \\
\text { стиль } \\
\text { жизни }\end{array}$ & $\begin{array}{c}\text { Профилак- } \\
\text { тический }\end{array}$ & $\begin{array}{c}\text { Пассив- } \\
\text { ный }\end{array}$ & $\begin{array}{c}\text { Умерен- } \\
\text { ный риск }\end{array}$ & $\begin{array}{c}\text { Вредное } \\
\text { влияние } \\
\text { работы }\end{array}$ & $\begin{array}{c}\text { Куриль- } \\
\text { щики }\end{array}$ & $\begin{array}{c}\text { Нездоро- } \\
\text { вый стиль } \\
\text { жизни }\end{array}$ \\
\hline Село & 0,103 & $-0,00792$ & 0,194 & $-0,0616$ & $1,041^{* * *}$ & $0,337^{*}$ & $-0,431^{*}$ \\
Константа & $-1,941$ & $-12,17^{* * *}$ & 0,890 & $-19,71^{* * *}$ & $-8,601^{* * *}$ & $-8,229^{* * *}$ & $-16,70^{* * *}$ \\
$N$ & 46690 & & & & & \\
Wald chi²(189) & 11425,77 & & & & & \\
Prob $>$ chi $^{2}$ & 0,0000 & & & & & \\
Log pseudo- & $-70973,69$ & & & & & \\
likelihood & & & & & \\
Pseudo R2 & 01801 & & & & & \\
\hline
\end{tabular}

${ }^{*} p<0,05$.

${ }^{* *} p<0,01$.

${ }^{* * *} p<0,001$.

\section{Литература}

Варламова С. Н., Седова Н. Н. 2010. Здоровый образ жизни - шаг вперёд, два назад. Сочиологические исследования. 4: 75-88.

Горина Е. А. 2012. Индекс человеческого развития в России и других странах мира. Обзор по материалам доклада ПРООН. SPERO. 16: 193-198.

Малик X. 2014. Доклад о человеческом развитии 2014. Обеспечение устойчивого прогресса человечества: уменьшение уязвимости и формирование жизнестойкости. New York, NY: United Nations Development Programme; М.: Весь мир. URL: http:/hdr.undp.org/sites/default/files/hdr14_a_full_ rus_21-01-15_0.pdf

Ефименко С. А. 2007. Потребители медицинских услуг в бюджетных организациях и их самооценка здоровья. Социологические исследования. 9: 110-114.

Ковалёва А. А. 2008. Самосохранительное поведение в системе факторов, оказывающих влияние на состояние здоровья. Журнал социологии и социальной антропологии. 11 (2): 179-191.

Колосницына М. Г., Бердникова А. Н. 2009. Избыточный вес: сколько это стоит и что с этим делать? Прикладная эконометрика. 3 (5): 72-93.

Назарова И. Б. 2007. Здоровье занятого населения. М.: МАКС Пресс.

Рощина Я. М. 2009. Микроэкономический анализ отдачи от инвестиций в здоровье в современной России. Экономический журнал ВШЭ. 13 (3): 428-451.

Рощина Я., Гремченко Е. 2016 (готовится к изданию). Кто в России придерживается здорового образа жизни? В сб.: Козырева П. М. (отв. ред.) Вестник Российского мониторинга экономического положения и здоровья населения НИУ ВШЭ (RLMS-HSE). М.: Национальный исследовательский университет «Высшая школа экономики».

Bloom D., Canning D. 2000. The Health and Wealth of Nations. Science. 287 (5456): 1207-1209. 
Bourdieu P. 1984. Distinction: A Social Critique of the Judgment of Taste (trans. R. Nice). Cambridge, MA: Harvard University Press.

Chan C. W., Leung S. F. 2015. Lifestyle Health Behavior of Hong Kong Chinese: Results of a Cluster Analysis. Asia-Pacific Journal of Public Health. 27 (3): 293-302.

Christensen V. T., Capriano R. M. 2014. Social Class Differences in BMI among Danish Women. Applying Cockerham's Health Lifestyles Approach and Bourdieu's Theory of Lifestyle. Social Science \& Medicine. 112: $12-21$.

Cockerham W. C. 2005. Health Lifestyle Theory and the Convergence of Agency and Structure. The Journal of Health and Social Behavior. 46 (1): 51-67.

Feng X., Astel-Burt T., Kolt G. S. 2014. Is an Index of Co-occuring Unhealthy Lifestyles Suitable for Understanding Migrant Health? Preventive Medicine. 69: 172-175.

Glorioso V., Pisati M. 2014. Socioeconomic Inequality in Health-related Behavior: A Lifestyle Approach. Quality \& Quantity: International Journal of Methodology. 48 (5): 2859-2879.

Griep R. H. et al. 2015. Job Strain and Unhealthy Lifestyle: Results from the Baseline Cohort Study, Brazilian Longitudinal Study of Adult Health (ELSA-Brasil). BMC Public Health. 15: 309-318.

Grossman M. 2000. The Human Capital Model. In: Culver A. J., Newhouse J. P. (eds) Handbook of Health Economics. Vol. 1A. Amsterdam: Elsevier; 347-408.

Heikkilä K. et al. 2013. Job Strain and Health-Related Lifestyle: Finding From an Individual-Participant Meta-Analysis of 118000 Working Adult. American Journal of Public Health. 103 (11): 2090-2097.

Mirowsky J., Ross C. E. 2003. Education, Social Status, and Health. New York: Aldine de Gruyter.

Short S. E., Mollborn S. 2015. Social Determinants and Health Behaviors: Conceptual Frames and Empirical Advances. Current Opinion in Psychology. 5: 78-84.

Singh-Manoux A., Marmot M. 2005. Role of Socialization in Explaining Social Inequalities in Health. Social Science \& Medicine. 60: 2129-2133.

Starfield B. 2000. Is US Health Really the Best in the World? Journal of the American Medical Association. 284 (4): 483-485.

Williams S. J. 1995. Theorising Class Health and Lifestyles: Can Bourdieu Help Us? Sociology of Health \& Illness. 17 (5): 577-604. 


\title{
NEW TEXTS
}

\section{Yana Roshchina \\ Health-Related Lifestyle: \\ Does Social Inequality Matter?}

\author{
ROSHCHINA, Yana - PhD \\ in Economics, Associate \\ Professor, Department of \\ Economic Sociology; Senior \\ Researcher, Center of \\ Longitudional Research; Senior \\ Research Fellow, Laboratory for \\ Studies in Economic Sociology, \\ National Research University \\ Higher School of Economics. \\ Address: 20 Myasnitskaya str., \\ Moscow, 101000, Russian \\ Federation.
}

Email: yroshchina@hse.ru

\begin{abstract}
In this research, some practices associated with a healthy lifestyle (e.g., playing sports, eating nutrition foods regularly, avoiding smoking, and not abusing alcohol) are investigated. On the basis of the RLMS-HSE data, we analyze how the percentage of Russians using these practices changed from 2000 to 2014, and how the adherence to the healthy lifestyle depends on the different socio-economic factors. Cluster analysis did not refute the hypothesis that many lifestyles exist between the most and the least healthy choices depending on which factor influences health. Thus, it was possible to find eight health-related lifestyles: healthy, unhealthy, and others in between them ("preventive", "passive", "neutral", "moderate risk", "negative effect of harmful work", and "smoking"), which are distinguished by the level of their risk index and by the main negative effect on health. Regression analysis has shown that, all other things being equal, social class significantly influences the choice of health-related lifestyle ("neutral" being
\end{abstract} a base category) for all styles except "moderate risk." A model using dummies of social classes as determinants is better construed than another one using the separate parameters of social status (e.g., education level, income, and professional status). Therefore, the "healthy" and "preventive" lifestyles are the most typical for "higher" and "higher-middle" classes. "Middle-middle" classes suffer from the negative effect of harmful work. Both "lower" and "lower-lower" classes are disposed to "passive" and "smoking" lifestyles. The "lower-lower" class also chooses the most "unhealthy" lifestyle, which is characterized by alcohol abuse.

Keywords: health-related lifestyle; social class; unhealthy habits; healthy lifestyle; alcohol consumption; playing sports.

\section{Acknowledgements}

The results of "The Russia Longitudinal Monitoring Survey - Higher School of Economics (RLMS-HSE) and Health Lifestyles Practices," carried out within the framework of the Basic Research Program at the National Research University Higher School of Economics (HSE) in 2015, are presented in this work. The author also wishes to thank all participants of the seminar series "Sociology of Markets" conducted by the Laboratory for Studies in Economic Sociology for their comments and suggestions.

\section{References}

Bloom D., Canning D. (2000) The Health and Wealth of Nations. Science, vol. 287, no 5456, pp. 12071209.

Bourdieu P. (1984) Distinction: A Social Critique of The Judgment of Taste (trans. R. Nice), Cambridge, MA: Harvard University Press. 
Chan C. W., Leung S. F. (2015) Lifestyle Health Behavior of Hong Kong Chinese: Results of a Cluster Analysis. Asia-Pacific Journal of Public Health, vol. 27, no 3, pp. 293-302.

Christensen V. T., Capriano R. M. (2014) Social Class Differences in BMI among Danish Women. Applying Cockerham's Health Lifestyles Approach and Bourdieu's Theory of Lifestyle. Social Science \& Medicine, vol. 112, pp. 12-21.

Cockerham W. C. (2005) Health Lifestyle Theory and the Convergence of Agency and Structure. The Journal of Health and Social Behavior, vol. 46, no 1, pp. 51-67.

Efimenko C. A. (2007) Potrebiteli meditsinskikh uslug v budzhetnykh organizatsiyakh i ikh samootsenka zdorov'ya [Consumers of Health Care Services Provided by Budget-Financed Organizations and Their Health Self-Estimation]. Sotsiologicheskie issledovaniya, no 9, pp. 110-114 (in Russian).

Feng X., Astel-Burt T., Kolt G. S. (2014) Is an Index of Co-occurring Unhealthy Lifestyles Suitable for Understanding Migrant Health? Preventive Medicine, no 69, pp. 172-175.

Glorioso V., Pisati M. (2014) Socioeconomic Inequality in Health-Related Behavior: A Lifestyle Approach. Quality \& Quantity: International Journal of Methodology, vol. 48, no 5, pp. 2859-2879.

Gorina E. A. (2012) Indeks chelovecheskogo razvitiya v Rossii i drugikh stranakh mira. Obzor po materialam doklada PROON [Human Development Index in Russia and Other Countries. A Review Based on the PROON Report]. SPERO, no 16, pp.193-198 (in Russian).

Griep R. H., Nobre A. A., Alves M. G., da Fonseca Mde J. , Cardoso Lde O., Giatti L., Melo E. C., Toivanen S., Chor D. (2015) Job Strain and Unhealthy Lifestyle: Results from the Baseline Cohort Study, Brazilian Longitudinal Study of Adult Health (ELSA-Brasil). BMC Public Health, no 15, pp. 309-318.

Grossman M. (2000) The Human Capital Model. Handbook of Health Economics (eds. A. J. Culver, J. P. Newhouse), vol. 1A, Amsterdam: Elsevier. pp. 347-408.

Heikkilä K., Fransson E. I., Nyberg S. T., Zins M., Westerlund H. et. al. (2013) Job Strain and Health-Related Lifestyle: Finding From an Individual-Participant Meta-Analysis of 118000 Working Adult. American Journal of Public Health, vol. 103, no 11, pp. 2090-2097.

Kolosnitsyna M. G., Berdnikova A. N. (2009) Izbytochnyy ves: skol'ko eto stoit i chto s etim delat'? [Excess Weight: How does it Cost and How should Deal with it?]. Prikladnaya ekonometrika, vol. 3, no 15, pp. 72-93 (in Russian).

Kovaleva A. A. (2008) Samosokhranitel'noe povedenie v sisteme faktorov, okazyvayushchikh vliyanie na sostoyanie zdorov'ya [Health-Related Behavior in a System of Factors Affecting Health]. Zhurnal sotsiologii i sotsial'noy antropologii, vol. 11, no 2, pp. 179-191 (in Russian).

Malik K. (2014) Doklad o chelovecheskom razvitii [Report on Human Development]. Obespechenie ustoychivogo progressa chelovechestva: umen'shenie uyazvimosti i formirovanie zhiznestoykosti [Sustaining Human Progress: Reducing Vulnerabilities and Building Resilience], New York, NY: United Nations Development Programme (PROON); Moscow: Ves' mir. Available at: http://hdr.undp.org/sites/default/files/ hdr14_a_full_rus_21-01-15_0.pdf (accessed 12 May 2016) (in Russian). 
Mirowsky J., Ross C. E. (2003) Education, Social Status, and Health, New York: Aldine de Gruyter.

Nazarova I. B. (2007) Zdorov'e zanyatogo naseleniya [Employed People's Health], Moscow: MAKS Press (in Russian).

Roshchina Y. M. (2009) Mikroekonomicheskiy analiz otdachi ot investitsiy v zdorov'e v sovremennoy Rossii [Micro-economic Analysis of Health Investments' Returns in Contemporary Russia]. HSE Ekonomicheskiy zhurnal, vol. 13, no 3, pp. 428-451 (in Russian).

Roshchina Y., Gremchenko E. (2016 [forthcoming]). Kto v Rossii priderzhivaetsya zdorovogo obraza zhizni? [Who Follows a Healthy Lifestyle in Russia?] Vestnik Rossiyskogo monitoringa ekonomicheskogo polozheniya i zdorov'ya naseleniya HSE (RLMS-HSE) (ed. P. M. Kozyreva), Moscow: HSE (in Russian).

Short S. E., Mollborn S. (2015) Social Determinants and Health Behaviors: Conceptual Frames and Empirical Advances. Current Opinion in Psychology, no 5, pp. 78-84.

Singh-Manoux A., Marmot M. (2005) Role of Socialization in Explaining Social Inequalities in Health. Social Science \& Medicine, no 60, pp. 2129-2133.

Starfield B. (2000) Is US Health Really the Best in the World? Journal of the American Medical Association, vol. 284, no 4, pp. 483-485.

Varlamova S. N., Sedova N. N. (2010) Zdorovyy obraz zhizni — shag vpered, dva nazad [Health Lifestyle One Step Forward, Two Steps Back]. Sotsiologicheskie issledovaniya, no 4, pp. 75-88 (in Russian).

Williams S. J. (1995) Theorising Class Health and Lifestyles: Can Bourdieu Help Us? Sociology of Health \& Illness, vol. 17, no 5, pp. 577-604.

Received: March 22, 2016.

Citation: Roshchina Y. (2016) Stil' zhizni v otnoshenii zdorov'ya: imeet li znachenie sotsial'noe neravenstvo? [Health-Related Lifestyle: Does Social Inequality Matter?]. Journal of Economic Sociology = Ekonomicheskaya sotsiologiya, vol. 17, no 3, pp. 13-36. Available at: https://ecsoc.hse.ru/2016-17-3.html (in Russian). 


\section{НОВЫЕ ПЕРЕВОДЫ}

\section{Ф. Доббин}

\section{Сравнительный и исторический подходы в экономической социологии ${ }^{1}$}

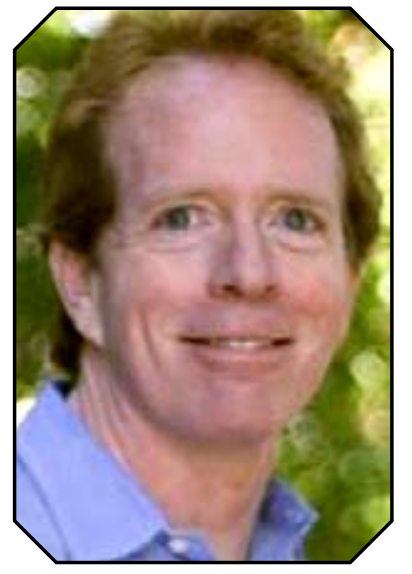

дОББИн Фрэнк (Dobbin, Frank) - профресcop социологии в Гарвардском университете. Адрес: МА 02138, США, г. Кембридж, Керкленд-стрит, д. 33, Уильям Джеймс Холл, 530.

\section{Email: frank_dobbin@} harvard.edu

Перевод с англ. Екатерины Головляницыной.

Научные редакторы Вадим Радаев, Григорий Юдин.

Публикуется с разрешения Princeton University Press.
В данной статье представлен обзор исторических и сравнительных исследований в экономической сочиологии, призванных объяснить многообразие форм хозяйственного поведения в разных странах и в разные времена. Для того чтобы провести полноценный анализ этих исследовательских направлений, предлагается абстрагироваться от принятой в экономической науке предпосылки о том, что хозяйственная деятельность определяется исключительно экзогенно - личным интересом актора. Автор подвергает сомнению представление об универсальной и внеисторичной экономической системе и показывает, что большинство социологов согласны: характер экономического поведения зависит от структурных, политических и культурных особенностей общества. Тем не менее в экономической социологии нет доминирующего объяснения ключевых факторов экономического поведения: одни исследователи делают ставку на роль социальных сетей, другие - на характер властных отношений, а третьи анализируют институты. Изначально сравнительные и исторические соичологические исследования рассматривали эти три подхода как взаимоисключающие, однако сейчас они всё чаще выступают как взаимодополняющие. Отталкиваясь от классических взглядов ключевых для экономической сочиологии теоретиков - Карла Маркса, Макса Вебера и Эмиля Дюркгейма, - автор категоризирует современные сравнительные исследования в зависимости от их теоретической перспективы. Несмотря на разнииу в подходах, все эти исследования объединяет индуктивная логика объяснения, предполагающая, что различия в экономической деятельности нельзя объяснить одним фактором.

Журнал «Экономическая сочиология» публикует перевод работы, которая ранее была опубликована в книге "The Handbook of Economic Sociology» («Хрестоматия экономической соџиологии») (2005).

Ключевые слова: сравнительный подход; исторический подход; индуктивный метод; власть; институты; сети.

\section{Введение}

Многие исследователи хозяйственной деятельности долгое время придерживались обыденного мнения о том, что хозяйственная жизнь управляет-

1 Источник: Dobbin F. 2005. Comparative and Historical Approaches to Economic Sociology. In: Smelser N. J., Swedberg R. (eds). The Handbook of Economic Sociology. Princeton, NJ: Princeton University Press; 26-48.

Автор благодарен Ричарду Сведбергу, Нилу Смелзеру, Джозефу Мэннингу, Брюсу Керратерсу и Фреду Блоку за комментарии и советы. - Примеч. автора. 
ся естественными законами. В экономической науке господствует представление о том, что характер хозяйственной деятельности (behavior) определяется, скорее, экзогенно, нежели эндогенно, то есть факторами, находящимися не внутри, а вне общества. Такой силой является следование личному интересу - внешнее по отношению к обществу, поскольку оно рассматривается как врождённое свойство человеческой природы. Руководствуясь личным интересом, человек выбирает наиболее эффективные средства для достижения определённой цели. Дальнейший ход мысли таков: поскольку экономическое поведение управляется инстинктами, для его предсказания не требуются сколь-либо обширные знания об обществе.

Данный подход кажется перспективным и социологам, не в последнюю очередь потому, что он находится в русле идей Просвещения о познаваемости Вселенной средствами науки. Есть нечто очень привлекательное в строгих математических формулах, способных объяснить и распространение света, и образование цен на кофе.

Однако социологи всё время сравнивали ситуацию в обществах в разные исторические периоды и неизбежно приходили к выводу о том, что львиную долю хозяйственных действий можно объяснить, только зная их социальный контекст. Действия управляющего фермой будут во многом зависеть от того, где находится эта ферма - в Хорватии или на Сицилии. Невозможно предугадать, как управлять железной дорогой в Кливленде, не зная, когда происходит дело - в 1880 г. или в 1980 г. Исторические и сравнительные исследования подчёркивают решающую роль общества в определении того, какую форму примет хозяйственная деятельность.

Основоположники социологии как науки стремились постичь тайны современности. Каким образом основой обществ становятся прогресс, рациональность и наука, если на протяжении стольких веков общества строились на основе традиций, мифов и ритуалов? Социологи усиленно искали ответы на этот вопрос, сравнивая ситуацию в обществах в разные исторические периоды. Сопоставление было вызвано пониманием того, что хозяйственная деятельность обусловлена социальным контекстом, то есть современные формы рационального поведения усваиваются человеком, а не являются врождёнными.

Использование сравнительного и исторического методов составляет одно из преимуществ социологии. Специалисты в области социологии прибегают к ним чаще, чем экономисты, и сами эти методы подчёркивают контекстуальные различия в хозяйственной деятельности. Социология и экономическая теория возникли как единая наука, и разница подходов проявилась не сразу. Экономисты постепенно теряли интерес к сравнительным и историческим исследованиям, предпочитая им нарочито нереалистичные модели рационального действия, поэтому идеи исследователей, подчёркивавших воздействие социальных институтов на хозяйственную деятельность, в том числе К. Маркса и М. Вебера, были отвергнуты экономистами и восприняты социологами.

Стремясь понять причины распространения современных форм хозяйственной деятельности, К. Маркс, М. Вебер и Э. Дюркгейм сравнивали докапиталистические и капиталистические общества. Маркс исследовал процесс перехода от феодализма к капитализму; Вебер - стимулы к капиталистическому развитию, связанные с протестантизмом; Дюркгейм - развитие капиталистической системы разделения труда. В то время, когда капитализм находился на ранних этапах развития, никто не мог с уверенностью предсказать, что современный промышленный капитализм окажется столь многообразным. Впрочем, Вебер описывал множество различных форм капиталистического устройства, включая грабительский, политический, империалистический, колониальный, авантюристический и фискальный капитализмы [Weber 1978 (1922): 164-167] (см. также: [Swedberg 1998: 47]). Эти авторы разработали сравнительный и исторический методы, чтобы объяснить причины различий в формах человеческой деятельности в разное время и в разных контекстах. 
Значительная часть исторических исследований посвящена затронутому в работах Маркса, Дюркгейма и Вебера вопросу о происхождении современных хозяйственных практик. Сторонники сравнительного метода, как правило, задаются другим вопросом: какие социальные силы обусловили существование столь выраженных различий между современными системами хозяйства? Если эволюция хозяйственных систем направляется человеческой природой, и эта природа у всех людей одинакова, то почему же хозяйственные системы принимают столь разные формы? Результаты исторических и сравнительных исследований в экономической социологии показывают: причина - в самом обществе; различия траекторий развития обществ определяются историей и стечением обстоятельств.

Настоящая работа содержит обзор исторических и сравнительных исследований в экономической социологии, нацеленных на объяснение того факта, что формы хозяйственной деятельности заметно различаются во времени и пространстве. Большинство социологов согласны с тем, что модели хозяйственной деятельности определяются социальными процессами, а не только инстинктами, однако расходятся в том, какие именно социальные процессы имеют решающее значение. Некоторые указывают на властные отношения, другие - на институты и социальные конвенции, третьи говорят о социальных сетях и ролях. Ранее в сравнительных и исторических социологических исследованиях эти три подхода рассматривались как взаимоисключающие, однако сейчас они всё чаще выступают как взаимодополняющие.

Далее будут рассмотрены теоретические основания властного, институционального и сетевого подходов. Затем я опишу методы исследования, применяемые в рамках исторического и сравнительного подходов, и перейду к обзору эмпирических работ.

\section{Как власть, институты и сети структурируют хозяйственную деятельность}

Рассуждения большинства экономических социологов построены на методе индукции: они изучают, как различаются формы хозяйственной деятельности в странах и в исторические периоды, а затем прослеживают связь этих различий с социальным контекстом. В этом состоит их явное отличие от дедуктивного подхода большинства экономистов-неоклассиков, которые исходят из допущения, что хозяйственная деятельность объясняется личным интересом. Эмпирические исследования таких феноменов, как инвестиции в среде ранних протестантов, управление новыми предприятиями в рыночном секторе экономики Китая или деловые стратегии виноделов Аргентины, породили множество догадок в отношении того, какие силы структурируют хозяйственную деятельность. Но обычно всё сводится к одному из трёх социальных явлений: власть, институты или сети. Каждое из них раскрывается в рамках соответствующей теории.

\section{Власть}

Властные отношения воздействуют на хозяйственную деятельность как напрямую (например, когда обладающая большей властью фирма навязывает свою волю «слабому» поставщику), так и опосредованно (например, когда обладающая властью промышленная группа добивается изменения законодательства в свою пользу). Структурная теория власти непосредственно опирается на идеи К. Маркса, хотя и не все её представители считают себя марксистами. К структуралистам принадлежат Н. Флигстин [Fligstein 1990], У. Рой [Roy 1997], Б. Минц и М. Шварц [Mintz, Schwartz 1985], М. Юсим [Useem 1996] и Ч. Перроу [Perrow 2002]. Они изучают, каким образом группам, обладающим властью, удаётся преподносить практики и меры государственной политики, которые служат их собственным интересам, как соответствующие интересам общества в целом. Маркс называл капиталистическое государство инструментом класса капиталистов, прикрывающим существование этого государства доктриной политического либерализма. Он полагал, что современное государство обслуживает интересы одной 
группы, но утверждая, при этом, что действует во имя общего блага. В структурной теории власти рассматривается роль властных отношений в формировании государственной политики, корпоративных стратегий и действий индивидов, которые обычно считаются сугубо рациональными. Когда какой-либо группе удаётся настоять на реализации выгодной для неё политики или деловой стратегии и сделать этот способ действий общепринятым, такая группа получает возможность наращивать свою власть и богатство, не прибегая каждый раз к принуждению.

\section{Институты}

Хозяйственная деятельность структурируется социальными институтами, то есть конвенциями, и тем смыслом, который люди приписывают этим конвенциям. Как утверждал Вебер [Weber 1978], социальные конвенции ${ }^{2}$ следует рассматривать с точки зрения субъективного смысла, который связывают с ними индивиды, так как мы наделяем свои действия определённым смыслом, мы способны понимать этот смысл (см. [Swedberg 1998]). Социологи-институционалисты считают, что предсказуемость и регулярность хозяйственной деятельности обеспечиваются не универсальными законами хозяйственной жизни, а существованием наделённых смыслом институциональных сценариев [Meyer, Rowan 1977; Powell, DiMaggio 1991; Scott 1995]. Современные модели поведения в сильной степени рационализированы. Мы знаем, например, что решение о сокращении штатов может означать как избыток рабочей силы, так и то, что прибыль фирмы не оправдывает ожиданий фондового рынка. Таким образом, обычаи хозяйственной деятельности наделяются смыслами и распространяются зачастую подобно модным веяниям. Стоило возникнуть моде на сокращение штатов, как фирмы вдруг принялись увольнять работников независимо от своих потребностей в этом [Budros 1997]. С Вебера начиная, институционалисты также обращали внимание на то, как социальные институты более высокого порядка - такие, как религия, образовательная система, рынок труда - ограничивают и структурируют хозяйственную деятельность.

\section{Социальные сети}

Социальную сеть, к которой принадлежит пользователь, социологи обычно называют его сверстниками или ролевыми моделями (role models). И она влияет на поведение пользователя, предоставляя примеры действий в конкретных ситуациях и применяя санкции в случае совершения нежелательных действий. Сетевая теория опирается на сформулированное в работах Г. Зиммеля и Э. Дюркгейма представление о том, что поведение и идентичность человека формируются его социальной средой. Дюркгейм полагал, что социальные сети влияют на индивидуальные действия не только негативно, препятствуя антиобщественному поведению, но и позитивно, закрепляя образцы правильного поведения. М. Грановеттер [Granovetter 1985] с помощью сетевого подхода продемонстрировал некорректность объяснения ценовых спекуляций (price gouging), которое предлагали экономисты из числа сторонников теории трансакционных издержек. Они полагали, что спекуляция возникает, когда продавец оказывается единственным поставщиком необходимого товара. Грановеттер же утверждает, что в рамках отрасли существует сеть, члены которой следуют неформальной норме, направленной против спекуляции: продавец, который станет спекулировать в период дефицита, рискует лишиться клиентов в период изобилия. Таким образом, межличностные сети закрепляют нормы, применяя санкции к нарушающим их членам сети. Согласно теории развития общество с сильными социальными сетями получает преимущество, в том числе за счёт более эффективных механизмов позитивного и негативного санкционирования.

2 В знакомом русскому читателю переводе А. Филиппова немецкое слово Konvention переводится не как «конвенция», а как «условность» (см.: Вебер М. 2008. Основные социологические понятия. Социологическое обозрение. 7 (2): 111$)$. Примеч. науч. ред. 
Исследователи роли власти, институтов и сетей в хозяйственной жизни заимствуют идеи друг у друга и постепенно создают единый подход к проблемам исторической и сравнительной экономической социологии. Точек соприкосновения между ними достаточно много. Хозяйственные практики (модели поведения, зафиксированные, например, в стратегиях ценообразования или в организационной структуре фирм) возникают в сетях акторов как результат институционализации сценариев, предписывающих тот или иной способ действий для достижения определенной цели. Обладающие властью акторы пытаются изменить существующие сценарии и повлиять на правила игры, которые институционализируются в политике государства. Возникающие при этом хозяйственные практики, или сценарии, изменяют восприятие участников рынка и предопределяют их реакцию на будущие события. Иными словами, хозяйственные практики возникают в ходе сугубо социальных процессов, когда социальные сети и властные ресурсы используются для того, чтобы определить те или иные практики как рациональные. Во многих из рассмотренных ниже исследований сочетаются идеи двух либо всех трёх этих подходов.

\section{Сравнительный метод в экономической социологии}

Если исходить из допущения, что «история отбирает лучшее», то в мире всё очевидно, в том числе и в мире хозяйства. Все экономики развиваются в одном направлении, стремясь к некоему оптимальному состоянию; каждое изменение - к лучшему, и в нём непременно проявляются естественные экономические законы. Современные практики, по определению, эффективнее существовавших прежде. Развитые общества ближе к идеалу, чем менее развитые; как следствие, задача модернизации, например, в Польше заключается лишь в том, чтобы превратить Варшаву в Нью-Йорк, то есть сделать Польшу более похожей на США.

Если же, подобно сторонникам исторического и сравнительного подходов в экономической социологии, исходить из допущения, что история не всегда отбирает лучшее, то придётся ответить на множество вопросов. Нужно объяснить не только причины наблюдаемых различий между хозяйственными практиками разных стран, но и причины существования столь же значительных различий в прошлом. Если счесть, что конгломераты сменили монопрофильные фирмы не потому, что оказались эффективнее, то следует предложить другое объяснение.

Каковы методы научного исследования, применяемые в рамках данного подхода? Здесь нелишне помнить о трёх вещах. Во-первых, следуя принципам социологии науки, необходимо воздерживаться от суждения об эффективности практик, даже когда сами акторы настаивают на такой эффективности. Во-вторых, согласно М. Веберу, важно стремиться понять смысл действия того, кто его совершает, для него самого. Это требование может показаться очевидным, однако любимый большинством экономистов дедуктивный метод исходит из того, что не имеет значения, как именно люди понимают собственные действия. В-третьих, как рекомендовали Э. Дюркгейм и Дж. С. Милль, нужно использовать метод аналитических сравнений, чтобы выявить факторы, влияющие на человеческое поведение.

Экономсоциологи заимствовали ряд исследовательских принципов из социологии науки. Новизна научных концепций и хозяйственных практик не считается основанием для признания их превосходства над прежними концепциями и практиками. Как указывал Д. Блур, социологическое объяснение науки должно быть каузальным, то есть исследовать происхождение знания; беспристрастным в отношении истинности научных суждений; симметричным, или предполагающим использование одинакового подхода к изучению как «истинных», так и «ложных» суждений [Bloor 1976]. Как в науке, так и в хозяйственной практике притязания на истинность и эффективность возникают и институционализируются в ходе социальных процессов; и не важно, будут они в конечном счёте признаны «верными» или «ошибочными». 
М. Вебер настаивал: нужно пытаться понять то, что Клиффорд Гирц позже назвал точкой зрения туземца. Большинство экономистов полагают, что люди способны действовать рационально, даже не зная об этом. Например, люди думают, что следуют религиозным предписаниям, но, с точки зрения экономиста, их поведение оказывается абсолютно рациональным. Как и Маркс, Вебер считал, что результаты действий индивида часто ускользают от внимания самого действующего, оставаясь незаметными для него самого. В то же время он подчёркивал, что важно понять субъективный смысл, который связывает с действием сам индивид [Weber 1978 (1922): 4]. Люди следуют хозяйственной конвенции, только когда они её понимают; поэтому, чтобы выяснить причину воспроизводства хозяйственных конвенций, необходимо установить, что они значат для людей.

Милль [Mill 1974 (1888)] и Дюркгейм [Durkheim 1982 (1938)] утверждали, что в социальных науках следует использовать только сравнительный метод исследования. Они исходили из ранних представлений о научном методе, согласно которым для установления причинной связи требовалось, как минимум, показать, что причина присутствует там, где наблюдается её предполагаемый эффект, и отсутствует там, где её предполагаемый эффект не выявлен. Для этого необходимо сравнить два наблюдения. В крупных статистических обследованиях изучаются данные о множестве наблюдений, выявляются корреляции и определяются причины социальных явлений. В лабораторных исследованиях устанавливаются причинные связи с помощью процедуры рандомизации, путем сравнения друг с другом объектов, которые подвергались и не подвергались воздействию стимула. Однако, как отметил Н. Смелзер, подобные лабораторные условия редко возникают в сравнительных исследованиях [Smelser 1976]. Как правило, страны различаются по множеству значимых параметров. Большинство исследователей стараются хотя бы показать, что в одной ситуации (конкретная страна или временной отрезок) имели место и предполагаемая причина, и следствие, а в другой не отмечено ни причины, ни следствия. Т. Скочпол и М. Сомерс предлагают сравнивать страны, схожие по большинству признаков [Skocpol, Somers 1980]. Ч. Реджин [Ragin 1987] рекомендует включать в анализ много разных стран, чтобы учесть возможное воздействие иных причинных факторов.

Во многих исследованиях для доказательства влияния одних факторов и исключения других используются и межстрановые, и исторические сравнения. Например, чтобы понять принципы новой промышленной политики в США, Великобритании и Франции накануне Великой депрессии, я сопоставил промышленную политику в этих трёх странах до и после депрессии и обнаружил, что во всех случаях правительства пытались преодолеть экономический спад, изменив направление промышленной политики [Dobbin 1993]. В частности, Ф. Рузвельт начал создавать картели. Депрессия стала шоком для всех стран, и ситуацию в каждой можно сравнивать как с ситуацией в ней же до депрессии, так и с другими странами. Во всех рассмотренных ниже исследованиях причинные связи выявлялись с помощью исторических и (или) межстрановых сравнений.

\section{Различия между формами и странами}

Большинство рассмотренных сравнительных исследований посвящено различиям в хозяйственной деятельности между фирмами, государственными институтами или странами. Такая расстановка акцентов отличает экономическую социологию от экономической теории, где основное внимание обычно уделяется работе институтов. Я разделяю исследования на три группы в зависимости от того, что принимается в качестве основной причины различий - власть, институты или сети и роли. Многие работы можно отнести более чем к одной группе, поскольку в них рассматриваются воздействия двух и более факторов. Работ по этой теме очень много, и поэтому вместо упоминания в двух словах о каждой значимой работе лучше рассказать о тех, которые могут служить примером каждого из этих подходов. Описание других исследований можно найти в работах, включённых в данную хрестоматию. Иными словами, я пожертвовал широтой охвата ради глубины анализа. 


\section{Власть: наследие К. Маркса}

Маркс первым использовал исторический подход в экономической социологии в исследованиях становления капитализма. Он возражал Гегелю, полагавшему, что история человечества, в том числе история хозяйства, движима диалектическим развитием идей, которые воплощаются в образе жизни людей и в организации хозяйства. Позиция Маркса была полностью противоположной: он считал, что идеи возникают под влиянием существующих хозяйственных отношений.

Хотя с распадом СССР стало очевидным, что предсказание Маркса о победе коммунизма над капитализмом не оправдалось, его метод и основные идеи вполне живы в экономической социологии. Метод прослеживания факторов, изменяющих со временем способы хозяйственной деятельности, повлиял на все направления исторической экономической социологии. Основная идея Маркса состояла в том, что история хозяйства управляется не просто абстрактными идеями, а производственными процессами и общественными отношениями. Как и экономисты-неоклассики, Маркс утверждал, что хозяйственная деятельность направляется личным интересом, но при этом учитывал, что, преследуя собственный интерес, люди не просто стремятся добиться наиболее выгодной цены в рамках каждой трансакции (как это предполагается в неоклассической экономической теории), а пытаются изменить мир в свою пользу. Маркс отводил проблематике власти ключевую роль, и этот подход нашёл отражение в ряде современных исторических исследований эволюции деловых практик.

Маркс оставил тонны рукописей о хозяйственной жизни. Экономсоциологи, изучающие отношения в области управления трудом (например, М. Буравой [Burawoy 1979] и Р. Бьернацки [Biernacki 1995]), часто обращаются к «Капиталу», последнему и главному труду Маркса [Marx 1994 (1867-1894)]. Однако более широкое влияние приобрели ранние работы Маркса, посвящённые переходу от феодализма к капитализму, в том числе «Немецкая идеология» [Marx 1974 (1845-1846)], «Восемнадцатое брюмера Луи Бонапарта» [Marx 1963 (1851-1852)], «Манифест Коммунистической партии» [Marx, Engels 1972 (1848)] и обширные наброски к «Капиталу» [Marx 1971 (1857)] 3 .

Каким образом изменения в производстве привели к переходу власти от аристократии к буржуазии, так что именно буржуазия стала задавать ход развития хозяйства и способствовала формированию капитализма? В «Немецкой идеологии» (1845-1846) Маркс прослеживает историю классовых конфликтов в Европе. В период феодализма возник и вырос класс ремесленников и производителей, активно торговавших своим товаром и расширявших производственные мощности. Данная группа людей оспаривала традиционные политические права и привилегии феодалов, господствующего класса, и настаивала на проведении политики, поощряющей развитие промышленности, - такой, как принятие законов о свободном труде и свободных выборах. Накапливая ресурсы, новый класс получал возможность изменять положение дел в политической и экономической сферах в свою пользу.

Как феодализм, так и капитализм служили интересам классов, владевших средствами производства (соответственно аристократии и буржуазии), и Маркса интересовало то, каким способом этим классам удавалось легитимировать служащие их интересам хозяйственные институты. Маркс утверждал, что современное государство навязывает капиталистические правила хозяйственной деятельности обществу, подавляющее большинство членов которого не являются капиталистами, и при этом использует риторику политического либерализма, а не капиталистического господства. В результате современное

3 Черновые рукописи «Капитала» 1857-1858 гг. долгое время оставались неизвестными исследователям. Рукописи были обнаружены в 1925 г. и впервые опубликованы целиком на языке оригинала под редакционным названием «Grundrisse der Kritik der politischen Ökonomie (Rohentwurf)» («Основные черты критики политической экономии (Черновой набросок)») в Москве, в 1939-1941 гг. Ф. Доббин ссылается на английский перевод фрагментов из первого берлинского издания 1953 г. - Примеч. перев. 
государство демонстрирует своим членам естественность и неизбежность капитализма, в то время как Маркс не считал его ни естественным, ни неизбежным. Сегодняшние теоретики власти заимствовали из этой схемы идею о том, что современное государство устанавливает набор определённых правил, норм и институтов, которые структурируют хозяйственную жизнь. Когда правительство проводит политику по установлению основополагающих правил хозяйственной конкуренции, в любом государстве граждане склонны считать, что такая политика выгодна всем в равной мере и соответствует законам экономики; её не воспринимают как результат ряда столкновений в борьбе за власть. Современные теоретики власти указывают на роль конфликтов и власти в создании подобных основополагающих правил и общепринятых деловых практик.

\section{Власть и смена организационных форм в США}

Далее приводится обзор историко-социологических исследований четырёх существенных сдвигов в организации американских фирм, начиная с середины XIX века. В каждом из этих случаев социологи показали, что изменения, которые обычно трактуются как рост эффективности, можно объяснить динамикой соотношений власти между разными группами. Почему на ранних этапах развития текстильной промышленности появились крупные производственные предприятия и почему впоследствии они стали господствующей формой организации производства? Почему в начале XX века множество отраслей прошли через процесс быстрого слияния фирм и консолидации собственности в руках нескольких крупных производителей? Почему после Второй мировой войны основной формой корпоративной организации стал диверсифицированный конгломерат? Почему к концу 1990-х гг. на смену ему пришли монопрофильные фирмы-гиганты?

Во всех четырёх случаях какая-либо конкретная группа (соответственно владельцы текстильных фабрик; финансисты с Уолл-стрита; ориентированные на финансовые показатели директора и институциональные инвесторы) меняла стратегии американских фирм и структуру американской промышленности, поскольку её представители полагали, что подобное изменение отвечает их интересам. В каждом из этих случаев надлежащей группе удавалось институционализировать новую модель ведения бизнеса, которую вскоре начинали воспринимать как само собой разумеющуюся и подкрепляли убедительной риторикой «эффективности».

\section{Чарльз Перроу: расцвет крупных предприятий}

По мнению Чарльза Перроу, на ранних стадиях развития распространение крупных текстильных фабрик и гигантских железных дорог в США было связано не с их высокой эффективностью, а с тем, что конституционные полномочия государственных чиновников по регулированию промышленности были очень незначительны [Perrow 2002]. Американское государство, созданное как противоположность тираническим европейским режимам, было наделено меньшими административными возможностями и намеренно оставлено открытым для воздействия со стороны тех групп, над которыми оно могло бы попытаться установить контроль. Это поощряло обладающих властью акторов к тому, чтобы переопределять по своему усмотрению права собственности (законы, устанавливающие правила торговли и форму организационного устройства). В начале XIX века представители американской деловой элиты изменили права собственности в пользу крупных корпораций. Богатые промышленники добивались принятия судебных и законодательных решений, которые предоставляли крупным корпорациям всевозможные преимущества над небольшими фирмами. В Европе государство защищало интересы небольших фирм и регулировало деятельность крупных игроков. В результате такого регулирования владельцы американских текстильных предприятий предпочитали использовать не трудоёмкие способы производства, а капиталоёмкие, даже если отдача была одинаковой, поскольку капиталоёмкие способы сокращали зависимость от работников, то есть усиливали их власть над работниками. По мере 
перехода на капиталоёмкие способы производства текстильные предприятия укрупнялись, их власть возрастала, но при этом был потерян важный альтернативный источник эффективности - предпринимательство. Таким образом, возникновение первых крупных предприятий в Америке невозможно объяснить с точки зрения эффективности.

\section{Уильям Рой: финансисты и распространение производственных олигополий в конце XIX - начале XX века}

Каким образом в начале XX века господствующей моделью в американской промышленности стала олигополистическая производственная фирма? Как показал Уильям Рой в работе «Социализация капитала: распространение крупных промышленных корпораций в Америке», ключевым фактором стала власть [Roy 1997]. Непредвиденным результатом принятия в 1897 г. антитрестовского законодательства стало изменение баланса власти между мелкими и крупными фирмами. Хотя целью законодательства было предотвращение концентрации хозяйственной власти путём запрета ценового сговора, крупные фирмы оказались в более выигрышном положении. Согласно законодательству, небольшие фирмы не имели права совместно устанавливать цены, но могли установить единую цену, объединившись в крупную фирму. В отличие от выдающегося историка американского бизнеса Альфреда Чандлера, полагавшего, что процесс укрупнения фирм на рубеже XIX-XX веков был обусловлен удешевлением производства за счет экономии от его масштаба [Chandler 1977], Рой видит преимущество крупных фирм в другом. Он показывает, что волна слияний прокатилась и по тем отраслям экономики, где экономия от масштаба была невозможна. Когда антитрестовское законодательство запретило фирмам объединяться в картели для установления цен, крупные фирмы поставили своих мелких конкурентов перед выбором: либо продать бизнес, либо неминуемо погибнуть в ценовой войне. Последовавшие слияния были обусловлены вовсе не производственной целесообразностью, а тем, что антитрестовское законодательство уничтожило картели - последнее прибежище небольших фирм. Так непредвиденное наложение эффектов государственной политики и частной хозяйственной власти привело к появлению модели крупной концентрированной фирмы.

Как обнаружили Тимоти Дауд и Фрэнк Доббин, введение антитрестовского законодательства и борьба за власть вызвали волну слияний и в железнодорожной отрасли [Dobbin, Dowd 2000]. К 1880 г. американские железные дороги объединились в картели, что позволяло предотвратить разрушительные для отрасли ценовые войны. Когда в 1897 г. Верховный суд США принял антитрестовское законодательство, финансисты, обычно владевшие акциями сразу нескольких железных дорог, осудили ценовые войны и приветствовали практику дружественных слияний, поскольку она позволяла сохранять стоимость акций. Финансисты во главе с Дж. П. Морганом угрожали участникам ценовых войн прекращением финансирования. Таким образом, благодаря усилиям обладавших хозяйственной властью финансистов повсеместно начались дружественные слияния, и ценовые войны удалось предотвратить.

\section{Нил Флиестин: ориентация менеджеров на финансовые показатели и распространение диверсифицированных конеломератов}

Почему те монопрофильные компании, которые возникли в результате описанных Перроу и Роем процессов, в 1950-1975 гг. превратились в диверсифицированные конгломераты? В книге Нила Флигстина «Трансформация корпоративного контроля» [Fligstein 1990] описывается борьба за лидерство в американских корпорациях между тремя группами менеджеров: между менеджерами по производству, по маркетингу и по финансам. История конкуренции между элитными группами в изложении Флигстина напоминает рассуждения Маркса о борьбе группировок во французской элите в работе «Восемнадцатое брюмера Луи Бонапарта» [Marx 1963 (1851-1852)]. 
Альфред Чандлер в книге «Видимая рука» утверждал, что после успешного решения маркетинговых задач менеджеры естественным образом сосредоточиваются на финансовых показателях и расширении портфеля активов (conglomeration) [Chandler 1977]. Флигстин показывает, что на самом деле причина заключается в борьбе финансовых менеджеров за власть. Принятие в 1950 г. поправок СеллераКефовера ${ }^{4}$ к антитрестовскому законодательству затруднило для фирм экспансию в смежные отрасли, и финансовые эксперты предложили новую теорию фирмы, согласно которой крупные фирмы уподоблялись инвесторам, управляющим диверсифицированным портфелем активов. Благодаря экономической теории портфеля приобрела распространение идея, согласно которой фирмам следует распределять риски и инвестировать прибыли в предприятия в отраслях с высоким потенциалом роста. Финансовые менеджеры преуспели в основном благодаря умению убеждать инвесторов и советы директоров в том, что будущее за диверсифицированными конгломератами, и только финансовые менеджеры обладают навыками для воплощения этой модели роста. Данная группа менеджеров заняла бо́льшую часть высших управленческих постов в корпорациях. Концепция Флигстина о роли власти и пропаганды выглядит убедительнее аргументов Чандлера о более высокой эффективности конгломератов потому, что диверсифицированные конгломераты впоследствии снова уступили место модели фирмы с ключевой компетенцией. Новым группам влияния удалось закрепить форму корпоративного управления, поразительно напоминавшую ту, что существовала до этапа конгломератов.

\section{Джеральд Дэвис, Нил Флигстин и другие авторы: институциональные инвесторы и распространение фирм, сконцентрированных на одном направлении деятельности}

Почему после 1975 г. диверсифицированные конгломераты уступили место фирмам, сконцентрированным на одном направлении деятельности, действующим по принципу ключевой компетенции? К 1990 г. характер корпоративных слияний и поглощений разительно отличался от ситуации, описанной Флигстином. В 1970 г. крупные фирмы скупали предприятия в других отраслях, стремясь диверсифицировать свои активы. Компания General Electric приобрела радио- и телевещательную компанию $N B C$, а табачная корпорация $R$. J. Reynolds - продуктовую компанию Nabisco. В 1990 г. крупные фирмы покупали предприятия в своих отраслях, чтобы в полной мере использовать собственные ключевые компетенции, то есть навыки управления предприятиями в своей отрасли. Теперь уже компания Daimler покупает Chrysler. Что же произошло? Как утверждают Джеральд Дэвис, Кристина Дикман и Кэтрин Тинсли [Davis, Diekmann, Tinsley 1994], а также Нил Флигстин и Линда Марковиц [Fligstein, Markowitz 1993], причиной появления новой модели стала позиция институциональных инвесторов и финансовых аналитиков, которые невысоко ценили диверсифицированные конгломераты и считали активы монопрофильных фирм более дорогими. По мере роста инвестиционных портфелей фирмы всё больше зависели от институциональных инвесторов и аналитиков, во власти которых оказалось установление стоимости акций. К тому же размер вознаграждения директоров зависел от текущей стоимости бумаг на бирже, а не от прибыли, что побуждало директоров считаться с мнением инвесторов и аналитиков. С изобретением техники враждебных поглощений возникла новая группа влияния - специалисты по поглощениям. Они получили власть разделять диверсифицированные фирмы, низко оценённые инвесторами и аналитиками. Это привело к изменению корпоративной стратегии: диверсифицированные фирмы стремились «понравиться» рынку, то есть тем же самым аналитикам и инвесторам. Данное объяснение подчёркивает, что одни акторы обладают властью изменять поведение других и, в частности, задавать критерии, согласно которым поведение считается рациональным.

4 Акт Селлера-Кефовера (Celler-Kefauver Antimerger Act) — антитрестовский законодательный акт, принятый в США в 1950 г. как поправка к Акту Клейтона (Clayton Act), то есть к федеральному антитрестовскому закону 1914 г.; запрещал фирме приобретать активы другой фирмы, если это приводит к ослаблению конкуренции. - Примеч. перев. 
Большая часть историй о роли власти в экономических отношениях (от рассказов, разоблачающих манипуляции первых железнодорожных и нефтяных магнатов, до бухгалтерских скандалов на пороге XXI века) - это сюжеты о злоупотреблении властью и о том, как отдельные индивиды злонамеренно подрывали правила в собственных интересах. Однако Маркс, Перроу, Рой, Флигстин и Дэвис показали, что власть, напротив, формирует правила игры и вырабатывает сценарии для фирм. Они продемонстрировали, что во всех этих случаях власть является неустранимым элементом. Обладающие значительной властью отрасли часто воздействуют на нормативный аппарат, регулирующий их деятельность [Useem 1984], и само представление о рациональном поведении фирмы обычно определяется исходом борьбы за власть между группировками управленцев. В исследованиях Перроу, Роя, Флигстина и Дэвиса использованы также идеи институционального и сетевого направлений в экономической социологии. В каждом случае значение имеют изменения в политике государства, и в каждом случае сети управленцев, институциональных инвесторов или финансистов играют значительную роль в установлении критериев рациональности.

\section{Власть и трудовой процесс}

Интерес Маркса к властным отношениям на современном промышленном предприятии во многом был вызван тем, что он ожидал падения капитализма после того, как рабочие осознают, что вся система фабричного производства основана на власти и эксплуатации. По Марксу, физическое принуждение и опасения рабочих потерять своё место давали капиталистам власть распоряжаться рабочими и предотвращать бунты. Причины, побуждающие рабочих сопротивляться власти класса капиталистов, а также причины неудач подобных попыток исследовали М. Буравой, Р. Бьернацки, Х. Кимельдорф и Й. Шенхав.

\section{Майкл Буравой: как фабричное производство поглотило классовый конфликт}

Работа Майкла Буравого «Производство согласия» [Burawoy 1979] является этнографическим и одновременно историко-социологическим исследованием фабричного производства, поскольку ее автор сравнивает собственные наблюдения с результатами похожего исследования Дональда Роя, проведённого на 30 лет раньше на том же предприятии ${ }^{5}$. Как отметили оба исследователя, рабочих удавалось вовлекать в борьбу за увеличение выпуска в результате особенностей организации труда. В цехе использовалась система сдельной оплаты, и рабочие с энтузиазмом включались в игру «кто больше заработает». За 30 лет изменился способ управления рабочим процессом. Именно это обстоятельство, по мнению Буравого, позволило ослабить остроту классовых конфликтов, снизить сопротивление и политическую активность рабочих. По наблюдениям Д. Роя, непосредственно в цехе работали специалисты по нормированию труда, и протесты рабочих приобретали политический характер, поскольку были направлены прямо на этих псевдоменеджеров. К моменту, когда М. Буравой приступил к исследованию, инженеры-нормировщики уже работали в отдельных офисах, и, как следствие, рабочие были менее склонны выдвигать политические требования к руководству. Когда работа в цехе стала выглядеть как абстрактная «игра без игроков», предсказанный Марксом классовый конфликт испарился.

\section{Ричард Бьернацки: культурное конструирование труда}

Ричард Бьернацки в работе «Производство труда» [Biernacki 1995] попытался понять, почему в Германии профсоюзные деятели чаще выступали с марксистской критикой капитализма, чем в Велико-

5 Д. Рой проводил этнографическое исследование поведения рабочих компании Allis Chalmers в Чикаго в 1944-1945 гг. Результаты представлены в его диссертации (Roy D. 1952. Restriction of Output in a Piecework Machine Shop. PhD dissertation, University of Chicago), а также в статьях: Roy D. 1952. Quota Restriction and Goldbricking in a Machine Shop. American Journal of Sociology. 60: 255-266; Roy D. 1954. Efficiency and "The Fix": Informal Intergroup Relations in a Piecework Machine Shop. American Journal of Sociology. 57: 427-442. — Примеч. перев. 
британии, где вместо попыток изменить капиталистическую систему стремились найти компромиссы, которые улучшили бы положение рабочих. Бьернацки связывает эти различия с различиями в институтах труда, а также в представлениях о роли рабочих в производственном процессе. В Великобритании рабочие текстильных предприятий получали сдельную оплату и в целом считались независимыми подрядчиками. В Германии рабочие полагали, что им платят непосредственно за труд - за каждое движение челнока в ткацком станке; кроме того, они находились под жёстким контролем со стороны менеджеров. В результате британские рабочие полагали себя независимыми индивидами, заключившими контракты с капиталистами, тогда как немецкие рабочие - слугами капиталистического класса. Причину этих различий в условиях труда Бьернацки усматривает в темпах развития рынков товаров и труда. В Великобритании рынок товаров сформировался раньше, и, когда возник свободный рынок труда, рабочие стали считать себя производителями товаров. В Германии оба рынка возникли одновременно, и рабочие рассматривали рынок труда как место, где они продают свою рабочую силу, а не результаты труда. По мнению Бьернацки, в Великобритании капиталистический класс получил власть благодаря стечению исторических обстоятельств, сформировавших определённое коллективное представление о фабричном производстве.

\section{Ховард Кимельдорф: когда рабочий класс действует как класс?}

Ховард Кимельдорф в работе «Бунтари или вымогатели?» [Kimeldorf 1989] использует сравнительный метод для ответа на вопрос, который Маркс считал едва ли не самым главным: что побуждает рабочий класс осознать, что его эксплуатируют, и начать действовать как класс? Кимельдорф сравнивает деятельность радикально настроенного профсоюза докеров Западного побережья США в период после Великой депрессии с действиями профсоюза докеров Восточного побережья, среди которых подобных настроений не наблюдалось. В портах Западного побережья докерами становились свободолюбивые иммигранты из Северной Европы, люди, чья профессия предполагала высокую степень автономии труда, - моряки и лесничие. На Восточном побережье для работы в доках набирали недавно иммигрировавших консервативных католиков, ирландцев и итальянцев, не имевших привычки к автономной работе. Кроме того, отрасль грузоперевозок на Западном побережье больше походила на монополию, что облегчало согласование позиций рабочих. Как утверждает Кимельдорф, классовый интерес возник вследствие сочетания прошлого опыта рабочих и особенностей структуры местных рынков труда.

\section{Йегуда Шенхав: инженеры и деполитизация менеджеров}

Йегуда Шенхав в книге «Производство рациональности: инженеры у истоков революции менеджеров» [Shenhav 2000] показал, что в 1875-1925 гг. американские менеджеры стали видеть свою задачу не в подавлении сопротивления рабочих, но в координации действий работников и технологических процессов. Так они пытались обрести легитимность в глазах политически активного рабочего класса. Инженеры переводили свой опыт систематизации и рационализации производства в управленческую риторику, что позволяло им занимать всё больше руководящих управленческих позиций. Отраслевые журналы распространяли убеждение, что следует расширить сферу приложения инженерных навыков - не ограничиваться конструированием машин, но перейти к разработке и рационализации самого процесса труда. Новый менеджмент должен был стать научно обоснованным, а не политически обусловленным. Исследуя идеологическую подоплеку организации трудового процесса, Шенхав продолжает традицию, заложенную «Капиталом» Маркса. Когда инженеры превратили менеджмент в отрасль абстрактной инженерной науки, то и сами менеджеры, и рабочие перестали воспринимать его как политическое предприятие.

Буравой, Бьернацки и Кимельдорф показали, что рабочие современных предприятий отказываются от радикальных форм профсоюзного движения не в результате принуждения, а вследствие особой орга- 
низации труда в цеху, особенностей развития процесса индустриализации либо специфики формирования рабочего класса. У всех трёх авторов хозяйственная деятельность рабочего класса определяется не властью как таковой. Шенхав связывает снижение политической активности рабочего класса с деполитизацией менеджмента вследствие активного вмешательства инженеров. Теперь перейдём от исследований роли властных отношений к работам, посвящённым тому, каким образом социальные институты воздействуют на хозяйственную деятельность.

\section{Институты: наследие Вебера}

Труды Маркса стали источником вдохновения для множества исторических исследований влияния власти и политики на хозяйственную деятельность. Труды Вебера, в свою очередь, стали источником вдохновения для множества сравнительных исследований воздействия социальных институтов, обычаев и конвенций на хозяйственную деятельность. В «Протестантской этике», в различных исследованиях мировых религий [Weber 1951 (1916); 1958 (1916); 1952 (1917)], а также в крупномасштабном исследовании капитализма «Хозяйство и общество» [Weber 1978 (1922)] Вебер пытался понять обычаи разных народов, выявить представления, которые стоят за этими обычаями, а также силы, вызывающие изменения обычаев. Вебер полагал, что существование обычаев поддерживается лежащими в их основе верованиями. Таким образом, он указывал на необходимость понять тот смысл, который действие имеет для того, кто его совершает. Рациональность не в глазах смотрящего, но в уме действующего. Существование институтов поддерживается теми общими смыслами, которые воплощены в этих институтах. Вебер был сторонником широкого взгляда на причины хозяйственной деятельности. В своих сравнительных исследованиях мировых религий он утверждал, что на хозяйственную деятельность влияют различные социальные институты - право, государство, религиозная и классовая системы (см. подробнее: [Swedberg 1998]). В работах Вебера продемонстрированы единство и связность различных институциональных сфер общества - не важно, идёт ли речь об индуизме или о протестантизме. Эти сферы взаимно подкрепляют друг друга и следуют общей логике (например, логике подчинения традиции или стремления к прогрессу).

Работы Вебера побудили некоторых исследователей отвлечься от конкретных хозяйственных взаимодействий и обратиться к изучению институциональной среды, в которой происходят эти взаимодействия. В рамках данного направления рассматривается характер социальных институтов, а также изучаются те смыслы, которые лежат в основе социальных конвенций и поддерживают их существование.

\section{Национальные хозяйственные институты}

\section{Макс Вебер: протестантизм, католицизм и расцвет капитализма}

Макс Вебер был немецким профессором экономики, но книга «Протестантская этика и дух капитализма» сделала его одним из основателей экономической социологии [Weber 2002 (1905)]. Вебер связывает происхождение современного («рационального») капитализма с появлением особого направления в раннем протестантизме. В отличие от Маркса, который всегда считал фундаментом хозяйственных конвенций классовые отношения, Вебер полагал, что хозяйственные обычаи могут зависеть от таких факторов, как класс, традиция или идеология. В данном случае неожиданное влияние на развитие капитализма оказала новая этика религиозных сект ${ }^{6}$ Через 10 лет после выхода «Протестантской этики» Вебер начал работу над тремя большими исследованиями связи мировых религий и хозяйства. В книгах «Религия Китая» [Weber 1951 (1916)], «Религия Индии» [Weber 1958 (1916)] и «Древний иудаизм»

6 О Вебере также см.: [Smelser, Swedberg 2005; Wuthnow 2005] — Примеч. автора. 
[Weber 1952 (1917)] Вебер связал особенности хозяйственных систем с религиозной этикой и, шире, со спецификой социальных институтов.

Вебер, видевший в протестантизме совместимую с капитализмом религиозную идеологию, задавался вопросом о том, почему среди всех мировых религий подобная этика возникла только в рамках протестантизма. В раннем кальвинизме провозглашалась доктрина предопределения, согласно которой участь, которая ждёт каждого человека после смерти, уже определена в момент его рождения. Хотя человек не может надеяться заработать место в раю, Бог даровал каждому земное призвание, и тот, кто напряжённо трудится и преуспевает, может, по крайней мере, рассматривать свой успех как признак божественного одобрения. Согласно трактовке Кальвина, Бог также требует от человека самоотречения и аскезы. Следуя идее о божественном призвании, протестанты посвящали себя своему делу, а идея аскетизма побуждала их к накопительству. Некоторые авторы утверждают, что стимулы к такому поведению возникали и в католицизме (см., например: [Novak 1993]), другие же видят главное воздействие протестантизма в том, что он способствовал бюрократизации государственного аппарата [Gorski 1993]; но новаторство Вебера заключается не столько в предложенных им конкретных объяснениях, сколько в самом подходе к взаимному переплетению хозяйства и общества.

Сравнивая протестантизм с другими мировыми религиями, Вебер обнаружил, что они также ориентированы на спасение, но предлагают другие пути к его достижению [Swedberg 1998: 138]. В протестантизме признаком спасения (пусть и не средством его достижения) выступали набожность, аскетизм и посвящение себя исполнению своего призвания. В конфуцианстве и индуизме спасение достигалось приятием наличного положения человека и уходом от мира в молитве. Эти религиозные этики поощряли традиционализм и созерцательность, а не активность и предпринимательство. В древнем иудаизме препятствием для развития рационального капитализма стало то, что религиозная мудрость ценилась выше предпринимательства. В сравнительных исследованиях Вебер проиллюстрировал описанную в «Хозяйстве и обществе» связь хозяйственных обычаев с более крупными социальными институтами - правом, государством, религией, классовой системой, и показал — что для понимания хозяйственных конвенций необходимо проследить их связь с этими институтами.

\section{Ричард Уитли: анализ национальных деловых систем}

В своих исследованиях национальных деловых систем Ричард Уитли подошёл к изучению капитализма так же, как Вебер подходил к исследованию мировых религий: он выявил логику, лежащую в основе каждой формы капитализма, что позволило понять смысл конвенций для акторов и увязать хозяйственные конвенции с более общей институциональной средой. Вебер продемонстрировал, как различия в религиозных представлениях о спасении соотносятся с различиями в предписываемых правилах поведения в земной жизни. Уитли показал, что различия между нациями в представлениях об эффективности, институционализированные в национальных деловых системах, соответствуют различиям в предписываемом хозяйственном поведении. Уитли пришёл к выводу, что экономическая эффективность разных хозяйственных систем примерно одинакова (Вебер не занимался оценкой эффективности разных путей к спасению).

Уитли начал с изучения национальных хозяйственных и политических институтов, что позволило ему понять характер отношений между государством и промышленностью, покупателем и поставщиком, между промышленностью и финансовым сектором. Институты возникают благодаря исторически сложившемуся стечению обстоятельств, однако со временем в дополнение к ним формируются подкрепляющие их обычаи и конвенции. Брайан Артур назвал этот процесс блокировкой (lock-in) [Arthur 1988]. Известный пример приводит Пол Дэвид: на первых пишущих машинках раскладка клавиатуры предназначалась для снижения скорости набора, так как конструкция машинки не допускала быстрый набор; 
однако в дальнейшем изменить раскладку оказалось невозможно, поскольку люди привыкли именно к такому расположению клавиш [David 1985]. Трудности с заменой раскладки возникли потому, что освоившие её машинистки полагают, что она достаточно эффективна. По утверждению Уитли и авторов других сравнительных исследований, похожий процесс институционализации проходят и другие хозяйственные конвенции: люди начинают воспринимать их как данность и обучаются обращению с ними.

Сначала Уитли обратился к деловым системам Восточной Азии [Whitley 1992a]. В Японии господствуют крупные корпорации (кайша), крупные фирмы различного профиля объединены в контролируемые банками бизнес-группы (наследники довоенных дзайбаиу), а государство активно поддерживает экспортные отрасли и планирует развитие промышленности. В Корее преобладают контролируемые семьями конгломераты (чеболи); отношения между фирмами представляют собой симбиотические отношения между членами конгломерата, а государство активно поддерживает создание и экспансию крупных и устойчивых бизнес-империй. На Тайване и в Гонконге доминируют небольшие китайские семейные предприятия; отношения между фирмами слабо структурированы, существует лишь несколько семейных бизнес-групп среднего размера (изитуань ичие), а государство почти не вмешивается в деятельность фирм. Воздействие каждой из этих трёх различных систем распространяется на все виды хозяйственной деятельности. Например, по-разному происходит выход фирмы на рынок в новых экспортных отраслях: в Японии новые фирмы получают финансирование от бизнес-групп, на Тайване и в Гонконге - от семей, владеющих собственным мелким бизнесом; в Корее новые фирмы получают субсидии от государства под покровительством одного из существующих чеболей. То, что рационально в рамках одной системы (например, начать бизнес, опираясь на поддержку семьи), будет сочтено безрассудством в другой. По мнению Уитли, азиатское экономическое чудо основано по меньшей мере на трёх разных системах (см.: [Johnson 1982; Cumings 1987; Westney 1987]); и, как показали дальнейшие исследования, деловые системы в Европе отличаются неменьшим разнообразием [Whitley 1992b; Whitley, Kristensen 1996].

\section{Фрэнк Доббин: как хозяйство становится отражением политического устройства}

Вебер продемонстрировал, что в разных обществах на хозяйственные практики оказывают воздействие древние религиозные институты. В книге «Промышленная политика: США, Великобритания и Франция в эпоху железных дорог» я показал на примере разных обществ, каким образом ранее существовавшие политические институты повлияли на промышленную стратегию государства и собственно на развитие промышленности [Dobbin 1994]. Промышленные стратегии эпохи модерна определялись логикой отношений между государством и частным сектором. В политическом устройстве США ключевую роль играли самоуправляющиеся сообщества, а также федеральное правительство, выступавшее третейским судьёй. Тот же принцип американцы применили к политике в железнодорожной отрасли: свободный рынок, независимые предприятия и федеральное правительство в качестве арбитра. Во Франции, где понимание демократии прямо противоположно американским принципам, в центре политической системы находилось сильное централизованное государство, ориентированное на подавление группировок, представляющих угрозу его суверенитету. Этот принцип централизованной координации французы перенесли на регулирование железнодорожной отрасли: государство получило исключительное право планировать сети частных железных дорог и управлять их развитием. Третья форма демократического устройства сложилась в Великобритании: ключевым принципом стало обеспечение максимальной независимости гражданина. Рассматривая вопрос о развитии железных дорог, англичане не допускали и мысли о том, что государство станет регулировать рынки, как в США, или планировать направление магистралей, как во Франции. Английские владельцы железных дорог были предоставлены самим себе, и для защиты от конкурентов они объединялись в картели, подавляя таким образом ожесточённую конкуренцию. 
В каждой из стран политическое устройство определило понимание социального порядка и тем самым повлияло на выбор принципов организации промышленности. В результате хозяйство стало отражением политического устройства: на рынках США федеральное правительство стало выступать третейским судьёй, во Франции централизованный госаппарат принялся защищать ключевые отрасли промышленности и планировать их развитие, а в Великобритании государство обязалось оставлять максимум возможностей для личной инициативы.

\section{Действие и хозяйственные институты}

Многие институциональные исследования неовеберианского толка грешат недостатком внимания к роли интересов и действия в возникновении институтов; в частности, этот недостаток определённо характерен и для рассмотренных выше работ [Swedberg 2001]. Другие авторы, напротив, уделяют внимание тому, каким образом индивидуальное действие влияет на хозяйственные институты, либо как институты направляют действие. Гэри Гамильтон и Николь Биггарт показывают, что после Второй мировой войны политические лидеры Японии, Южной Кореи и Тайваня предпочли придерживаться стратегий промышленного развития, основанных на традиционных системах власти; но при этом исследователи подчёркивают, что у этих лидеров действительно был выбор, и они могли выбрать и иные альтернативы. Мауро Гиллен демонстрирует, как политики, предприниматели и менеджеры выстраивают стратегии исходя из сравнительных преимуществ, которые дают специфические способы организации производства в их странах, и тем самым усиливают эту специфику. Эдгар Кизер и Йоахим Шнайдер используют теорию агентских отношений, чтобы объяснить, почему система налогообложения в Пруссии оказалась исключительно эффективной. Брюс Керратерс показывает, как в Великобритании XVIII века первым держателям акций удавалось достигать политических целей через торговлю ценными бумагами.

\section{Гэри Гамильтон и Николь Бигеарт: азиатский бизнес и докапиталистические социальные отношения}

Гэри Гамильтон и Николь Биггарт объясняют происхождение различий между азиатскими хозяйственными системами в терминах традиций и действия [Hamilton, Biggart 1988; Orrù, Biggart, Hamilton 1991]. Они видят истоки этих систем в решениях политиков послевоенного периода: выбранная стратегия легитимации использовала некоторые особенности традиционных структур власти. По мнению Гамильтона и Биггарт, послевоенные отношения государства и промышленности конструировались целенаправленно, но набор возможных альтернатив был предопределен исторически.

В Японии обладающие значительной властью межотраслевые промышленные группы сосуществуют с государством, которое оказывает им помощь в планировании и координации действий. После войны дзайбацу были распущены американскими оккупационными властями, и политикам пришлось выстраивать отношения непосредственно на основе системы власти, оставшейся от династии Токугава и эпохи Мэйдзи, когда фигура сёгуна, или императора, находившегося «выше политики», образовывала слабый центр, окружённый могущественными, но лояльными независимыми силами [Hamilton, Biggart 1988: S81]. Тайвань и Южная Корея после войны в поисках легитимации политической системы опирались на нормы конфуцианства. Когда в Корее вспыхнула гражданская война, южнокорейское правительство выбрало стратегию промышленного роста, и фавориты президента превратились в руководителей огромных промышленных империй. Режимы Ли Сын Мана и Пака Чон Хи эксплуатировали образ сильного централизованного конфуцианского государства со слабыми группами влияния. В результате возникли крупные семейные бизнес-группы, обязанные своим существованием государству. На Тайване Чан Кайши создал государство, основанное на сформулированном в поздний имперский период конфуцианском принципе справедливого обращения с населением. В послевоенном Тай- 
ване частным лицам было разрешено создавать собственные хозяйственные предприятия. Возникшая в итоге система напоминала Китай периода поздней империи: мелкие семейные фирмы, напрямую контактирующие с поставщиками и покупателями. В обоих случаях политики, пытавшиеся выстроить новые хозяйственные институты и придать им легитимность с помощью следования традиции, намеренно использовали именно те элементы традиционных структур власти, которые облегчали достижение их собственных целей. Старые политические институты оказали влияние на новые хозяйственные институты, но лишь опосредованно, через действия расчётливых политиков.

\section{Мауро Гиллен: создание преимуществ из национальных различий}

В книге Мауро Гиллена «Пределы конвергенции» [Guillén 2001] рассмотрены разные стратегии фирм и отраслей в развивающихся хозяйствах Аргентины, Южной Кореи и Испании. Гиллен оспаривает привычные представления о конвергенции, согласно которым все страны, в конце концов, приходят к одним и тем же «лучшим практикам» производства всех без исключения товаров. Напротив, как утверждает Гиллен, политики, предприниматели и менеджеры сохраняют особенности своей промышленной организации и используют их как способ обозначить свои отличия от остальных и создать собственные рыночные ниши. Экономики этих стран вовсе не становятся более похожими; напротив, они опираются на те особенности, которые считают своими преимуществами, для того чтобы оставаться разными.

Поразительно, что различия в государственной политике ведут к тому, что несходства между этими странами заметны и на уровне отдельных отраслей: в каждой стране такие отрасли, как виноделие, банковское дело, автомобилестроение, обладают особой структурой и благоприятствуют разным типам собственников. Однако в своём контексте каждая из этих политик оказалась очень эффективной. Проводимая в Южной Корее активная протекционистская и централизованная политика экономического роста обеспечила крупным интегрированным бизнес-группам преимущество перед транснациональными корпорациями и мелкими фирмами. В Испании итогом прагматичного и гибкого регулирования стало широкое присутствие транснациональных корпораций, наличие множества разнообразных мелких местных фирм, а также крупных отечественных производителей в традиционно олигополистических секторах. Популистски ориентированная политика властей Аргентины препятствовала проникновению транснациональных фирм в ряд секторов, но поощряла развитие бизнес-групп, способных создать стабильность и экономическую базу для расширения конкуренции. В этих странах одни и те же отрасли оказались весьма по-разному организованы. Очевидно, что одна и та же отрасль может быть эффективно организована множественными способами. Любая единожды выбранная система организации в дальнейшем самовоспроизводится, поскольку индивиды разрабатывают свои хозяйственные стратегии на основе предоставляемых ей преимуществ. Во всех рассмотренных странах воздействие государства и юридических институтов на хозяйственную деятельность соответствует предположениям Вебера, однако индивиды использовали в своих интересах специфические особенности, возникающие в результате реализации государственной политики.

\section{Эдгар Кизер и Йоахим Шнайдер: агентские отношения и эффрективность прусской системы налогообложения в XVII-XVIII веках}

Эдгар Кизер и Йоахим Шнайдер по-своему подошли к концепции Вебера и придерживались совершенно иных взглядов, нежели их предшественники, на проблему действия [Kiser, Schneider 1995]. Вебер, которого интересовала прежде всего эффективность бюрократической формы организации, обобщил черты национальных государств начала XIX века в идеальном типе современной бюрократии. Он исследовал причины эффективности формальной бюрократии и полагал, что в XVII-XVIII веках Пруссия добилась исключительных успехов в сборе налогов именно благодаря высокой степени бюрокра- 
тизации. Кизер и Шнайдер показывают, что прусское государство с успехом справлялось со сбором налогов и до его бюрократизации. Опираясь на теорию агентских отношений, они демонстрируют, что источником эффективности стало отклонение от идеала бюрократии, позволившее приспособиться к особенностям конкретной ситуации. Согласно теории агентских отношений цель правителя - максимизация налоговых поступлений; цель агентов (сборщиков налогов) - максимизация своей доли в собранных налогах; цель налогоплательщиков — минимизация выплат. В Пруссии была создана система, позволявшая приводить интересы агентов в соответствие с максимальной выгодой правителя (например, с налоговыми откупщиками заключали долгосрочные условные контракты, что могло снижать издержки сбора налогов). Кизер и Шнайдер входят в число немногих экономсоциологов, применяющих в исследованиях концепцию рационального выбора, взятую из теории агентских отношений.

\section{Брюс Керратерс: как политика влияет на биржевую торговлю}

Похожий подход представлен в исследовании Брюса Керратерса, посвящённом ранним этапам развития биржевой торговли в Великобритании, где показано, что хозяйственная деятельность движима политикой, а не только узкими личными интересами. Вебер считал, что политические институты зачастую структурируют хозяйственное действие. Керратерс обнаружил, что динамика биржевой торговли зависит не только от цен, но и от политики государства. В книге «Город капитала: политика и рынки в период английской финансовой революции» [Carruthers 1996] под вопрос ставится основной постулат экономической теории цен, согласно которому продавцы выбирают покупателя, предлагающего самую высокую цену. Начало XVIII века было периодом бурной политической борьбы, и крупные компании оказывали значительное воздействие на принятие политических решений. Мажоритарные акционеры понимали, как велико влияние тех, кто контролирует Ост-Индскую торговую компанию. Керратерс приходит к заключению, что держатели акций значимых компаний, придерживавшиеся определённых политических взглядов, гораздо чаще продавали акции членам той же политической партии. Профессиональных биржевых торговцев это касалось в меньшей степени, чем частных акционеров. Ограничивая круг покупателей членами своей политической партии, продавцы могли потерять часть прибыли и тем не менее с большей вероятностью продавали акции «своим». Керратерс показывает, что сугубо политические воззрения могут воздействовать на хозяйственную деятельность даже в такой «заповедной» для экономической теории области, как биржевая торговля.

\section{Изменения национальных хозяйственных институтов}

Рассмотренные выше исследования институтов следуют двум постулатам Вебера: логика функционирования хозяйственных институтов является осмысленной для тех, кто участвует в воспроизводстве этих институтов; хозяйственные институты зависят от прочих институтов, составляющих среду, в которой они существуют, особенно - от политических институтов. Ещё одна группа исследователей обратилась к задаче объяснения изменений хозяйственных институтов, поставленной Вебером в наиболее ясной форме в работе «Протестантская этика и дух капитализма». Бай Гао рассматривает роль экономической теории в формировании стратегии современной промышленной политики в Японии. Книга Гао опирается на предположение Вебера о том, что появление новых идеалов может менять хозяйственные институты. Джон Кэмпбелл и его соавторы описывают, как изменения некоторых элементов общей конфигурации институтов привели к смене режимов управления (governance regimes) в американской промышленности. Их исследование основано на гипотезе Вебера о встроенности хозяйственных институтов в общую институциональную среду.

\section{Бай Гао: формирование промышленной политики в современной Японии}

Бай Гао в работах «Хозяйственная идеология и промышленная политика в Японии» [Gao 1997] и «Японская экономическая дилемма» [Gao 2001] рассматривает возникновение после 1930 г. уникаль- 
ной японской промышленной стратегии. Ключевыми для этой стратегии стали стратегическое планирование хозяйства, ограничение конкуренции регулированием рынков, борьба с ориентацией фирм на быстрое обогащение и поощрение более долгосрочного планирования. Данный подход возник под воздействием воззрений европейских экономистов: представлений К. Маркса о рисках неограниченной конкуренции, теории инноваций Й. Шумпетера, идей Дж. М. Кейнса о государственном регулировании экономических циклов. Японские политики и капиталисты, отвергнувшие ожесточённую конкуренцию ради экономической стабильности и саморегулирования промышленности, использовали эти суждения при создании уникальной японской промышленной политики.

В книге «Японская экономическая дилемма» Гао рассматривает последствия, которые эта система имела в 1990-е гг. Идея саморегулирования в промышленности хорошо работала в период экономического бума, но в период рецессии возобновилась жёсткая конкуренция: в попытках справиться со снижением прибылей фирмы принимали непродуманные инвестиционные решения. И если «Хозяйственная идеология...» подтверждает тезис Вебера о том, что идеи могут воздействовать на хозяйственные институты, то «Японская экономическая дилемма» - о том, что институты могут оказаться устойчивыми к изменениям. Сделать иным характер промышленной политики в Японии оказалось непросто, несмотря на то что прежний курс очевидно устарел.

\section{Джон Кэмпбелл, Роджерс Холлингсворт и Леон Линдберг: изменения структуры отрасли}

В книге «Управление американской экономикой» под редакцией Джона Кэмпбелла, Роджерса Холлингсворта и Леона Линдберга [Campbell, Hollingsworth, Lindberg 1991] продемонстрировано многообразие управленческих структур в разных отраслях промышленности США и предложено объяснение изменений структур управления на основе веберианского подхода. Рассмотрев восемь отраслей, авторы выделили несколько разных отраслевых конфигураций: рынки, слияния, системы мониторинга, сети обязательств, сети продвижения и ассоциации. Все исторические изменения в отраслевом управлении происходят сходным образом. Институты управления не меняются, если стабильна институциональная среда в целом (государственное регулирование, экономическая теория, институты поставок, потребительские практики). Внешние шоки могут дестабилизировать существующую структуру, будь то картель или конкурентный рынок, и тогда между разными группами начнётся борьба за формирование новой структуры. В периоды изменений власть играет ключевую роль. Кэмпбелл и его соавторы оспаривают преобладающее представление экономической теории трансакционных издержек [Williamson 1985], согласно которому фирмы изменяют форму управления тогда, когда это становится эффективным. В книге «Управление американской экономикой» показано, что, хотя низкая прибыль может создать стимулы к поиску новых механизмов управления, вызвать перемены могут и многие другие виды шоков. И, как правило, именно власть определяет, какая из альтернатив победит.

\section{Национальные институты управления}

Теперь перейдём к рассказу о сравнительных исследованиях систем управления фирмой. Эти системы занимают подчинённое положение относительно масштабных хозяйственных систем, рассмотренных выше. Рассуждения Вебера подсказывают, что различия в системах управления фирмой должны соответствовать различиям в институтах более высокого уровня, и многие исследования подтверждают это предположение.

\section{Райнхард Бендикс: социальная структура и идеология управления}

В масштабном исследовании Райнхарда Бендикса «Труд и власть в промышленности: идеологии управления в ходе индустриализации» [Bendix 1956] изучено происхождение управленческих практик 
и идеологий в четырёх странах. Почему в разных странах промышленностью управляют неодинаково? Страны, рассмотренные Бендиксом, различались по двум основаниям: возраст промышленности (в одних странах она возникла недавно, в других - давно); степень независимости управления от государства. В итоге получилась двумерная таблица, куда вошли начальный период индустриализации в Великобритании (независимое управление) и в царской России (подчинённое государству управление), развитая промышленность в США (независимое управление) и в ГДР (подчинённое государству управление).

Успешные практики управления появились не там, где промышленность возникла раньше, а там, где она была автономна. Идеология, поощрявшая рабочего к сотрудничеству путём демонстрации ему перспектив социальной мобильности (к этой идеологии менеджеры прибегают и сегодня), была создана в тех двух странах, где менеджеры не зависели от государства (США в поздний период и Великобритания), а не там, где управление промышленностью достигло более зрелого состояния (США и ГДР). В царской России и в коммунистической ГДР менеджеры не имели автономии и не сумели побороть представление о том, что они занимают своё место незаслуженно и администрация - лишь инструмент государственного принуждения. Во всех четырёх случаях практики управления зависели от отголосков старых представлений о классовых отношениях, а также от текущих отношений государства и классов. Например, в Англии аристократия, неприязненно относившаяся к развитию промышленности, была сильнее государства, и в результате государство предоставило капиталистических предпринимателей самим себе. Напротив, в царской России государство содействовало на ранних этапах развитию предпринимательства, и в результате первые капиталисты, как и сельскохозяйственная аристократия, оказались во власти государства. Пример ГДР накануне падения коммунистического режима показывает, что там, где государство подчиняет себе предпринимателей и промышленность, чтобы непосредственно руководить рабочими, шансы на возникновение успешной идеологии управления невелики.

Бендикс, подобно Веберу, изучал взаимодействие идей и хозяйственных практик. Он обнаружил, что схожие хозяйственные практики в одних условиях становятся легитимными, а в других — нет, и это во многом зависит от эффективности идеологии управления.

\section{Вольфгане Штреек: производственные отношения в развитых странах}

В сравнительном исследовании систем производственных отношений Вольфганг Штреек опирался на гипотезу Вебера о том, что хозяйственные конвенции встроены в более широкий контекст общественных институтов. В книге «Социальные институты и экономический успех» Штреек сравнивал системы производственных отношений в разных странах и исследовал связь между особенностями системы и её успехом в глобальной экономике [Streeck 1992]. Штреек полагает, что во всех странах исторически возникли разные институциональные конфигурации - разное устройство рынков труда, государственной политики занятости, образовательных институтов. И именно эти институциональные конфигурации задают контуры системы производственных отношений. В чём же состоят сравнительные преимущества разных систем? Страны с сильными институтами (Германия и Япония) в состоянии планировать развитие промышленности и образовательной системы, что даёт им преимущество перед странами, более склонными опираться на рынок (Великобритания и США), где решения принимаются на уровне индивидов, а коллективный выбор складывается из суммы индивидуальных решений.

В Германии наличие сильных профсоюзов и активное финансирование образовательной системы позволили наладить производство товаров с высокой добавленной стоимостью, требующее высококвалифицированных работников. Великобритания и США просто не располагают институциональными возможностями для такого решения. Примеры Германии и Японии показывают, что в современной экономике конкурентоспособность зависит от состояния социальных институтов, позволяющих стра- 
нам использовать систему производственных отношений, систему образования, а также корпорации для достижения коллективных целей.

\section{Герт Хофстеде: культура и трудовые ценности}

До логического завершения проект Вебера по описанию трудовых ориентаций индивидов довёл Герт Хофстеде, который разработал схему, характеризующую различия ценностей между 40 странами [Hofstede 1980]. Его исследование основано на результатах опроса работников транснациональной корпорации, имеющей офисы в 40 странах. Описывая отношения власти и трудовые ценности в этих странах, он выделил четыре измерения: дистанция власти (допустимая степень контроля со стороны руководства); избегание неопределённости (степень, в которой люди стремятся избежать стресса, связанного с неизвестностью); индивидуализм (значение индивида в сравнении со значением группы); маскулинность (относительная важность ценностей заработка и индивидуального достижения в сравнении с ценностями сотрудничества и благоприятной психологической обстановки). Хофстеде связывает культурные типы с характером общественных институтов и утверждает, что эти институты влияют на психологические установки работников. Отсюда, в частности, следует, что в зависимости от контекста рациональное действие может принимать очень разные формы: важно, считается ли приемлемым жёсткий контроль, насколько стрессовой является ситуация неопределённости, придаётся ли индивиду большая значимость, чем группе, а также отдаётся ли предпочтение индивидуальным достижениям по сравнению с сотрудничеством. Таким образом, Хофстеде удалось конкретизировать различные аспекты трудовой этики, описанной Вебером в «Протестантской этике». Подобно Веберу, он считает общественные институты первопричиной межстрановых различий.

\section{Японские институты управления}

Экономическое чудо послевоенной Японии всегда привлекало внимание экономсоциологов. Многие из них пытались повторить проведённое Вебером сравнение Востока и Запада на более современных эмпирических данных, чтобы выявить те особенности японского общества и организации труда, которые привели к беспрецедентно высоким темпам роста после Второй мировой войны.

\section{Рональд Дор: организация производства в Японии и Великобритании}

В своей книге «Британская фабрика — японская фабрика», положившей начало сравнению систем фабричного производства в разных полушариях Земли, Рональд Дор [Dore 1973] продемонстрировал значительные различия между рыночноориентированной системой управления в Великобритании и социальноориентированной корпоративной системой (welfare corporatism) в Японии. В Великобритании Дор обнаружил высокий уровень межфирменной трудовой мобильности, зависимость ставок заработной платы от внешнего рынка труда, низкую лояльность работников, мизерные социальные пакеты и разобщённость профсоюзов. В Японии он выявил низкий уровень внешней трудовой мобильности в сочетании с такими факторами, как развитые внутренние рынки труда и масштабные программы повышения квалификации, зависимость заработной платы от положения во внутрифирменной иерархии позиций, высокий уровень лояльности работников, большой социальный пакет и значительное влияние профсоюзов работников предприятий на организацию труда.

Дор утверждал, что источником этих различий является не культурная специфика, а разница в сроках индустриализации и условиях её протекания. Японская модель организации промышленности развивалась после Второй мировой войны, поэтому опиралась на передовые управленческие технологии, разработанные к тому времени, — на идеи о важности вовлечения работника в трудовой процесс и о необходимости долгосрочных стимулов, сближающих интересы работника с интересами фирмы. 
Кроме того, американские оккупационные власти поощряли сотрудничество управленцев и рабочих. Условия фабричного производства в Великобритании возникли гораздо раньше, до разработки современных подходов к мотивации работника и до того, как сложилось представление об эффективности сотрудничества профсоюзов и администрации. Дор был одним из первых социологов, утверждавших, что каждая страна сохраняет уникальные организационные характеристики, и в недавней работе показал, что конвергенция разных стран действительно практически не наблюдается [Dore 2000]. Тема японских управленческих практик освещена также в ориентированной на более широкую аудиторию работе Уильяма Оучи, показавшего, что практики, эффективные в Японии, могут оказаться полезными и для американских фирм [Ouchi 1981].

\section{Джеймс Линкольн и Арне Каллебере: сравнение систем трудовой организации в США и Японии}

Вебер утверждал, что дух капитализма подпитывался кальвинизмом. Но могут ли условия на конкретном рабочем месте повлиять на трудовую этику? Результаты исследования Джеймса Линкольна и Арне Каллеберга, основанного на опросе около 8000 рабочих в США и Японии, свидетельствуют о важности трудовых практик [Lincoln, Kalleberg 1985]. Хотя практики корпоративизма более распространены в Японии, они используются для повышения лояльности работников и в США. Японская система оплаты труда предполагает отсутствие внешнего рынка рабочей силы — размер заработной платы определяется положением в карьерной иерархии фирмы. Напротив, в США система оплаты труда предполагает конкуренцию между фирмами, поэтому размер заработной платы формируется на основании характеристик позиции и её положения в иерархии, а также под воздействием профсоюзов [Kalleberg, Lincoln 1988; Lincoln et al. 1990]. Вывод состоял в том, что различия между Японией и США имеют культурное происхождение: и обязательства работника, и обязательства работодателя (перед работником) являются частью более масштабной культурной системы. Результаты Линкольна и Каллеберга показывают, что трудовые практики сами по себе могут воздействовать на уровень лояльности. Основываясь на идеях Вебера, исследователи предположили, что локальные конвенции играют столь же важную роль в формировании трудовой этики, как и более крупные культурные системы.

\section{Распространение институтов управления}

Если Вебер интересовался преимущественно тем, как различаются обычаи в разных обществах, то современные экономсоциологи уделяют больше внимания факторам, облегчающим проникновение обычаев в другие организации и общества [Meyer, Rowan 1977; Powell, DiMaggio 1991]. Какова роль социальных институтов в распространении хозяйственных конвенций из одних обществ в другие?

\section{Мауро Гиллен: распространение управленческих парадигм}

В книге Мауро Гиллена «Модели управления: работа, власть и организация в сравнительной перспективе» [Guillén 1994] описано развитие трёх основных управленческих парадигм в США, Великобритании, Западной Германии и Испании. Опираясь на концепции Вебера и Бендикса, Гиллен исследует воздействие социоструктурных и идеологических факторов на представления о менеджменте. Чем обусловлено успешное распространение таких направлений менеджмента, как научная организация труда с характерными для неё исследованиями времени и движений работников и инженерным подходом к рабочему процессу, школа человеческих отношений, подчёркивающая необходимость гуманного обращения с работниками, и структурный анализ, который уделяет основное внимание связи между техническими требованиями и человеческим фактором? Решающую роль сыграла институционализация крупных бюрократизированных фирм, которые при желании способны ввести в моду новые управленческие практики. 
Немаловажна в этом процессе религия, что зачастую недооценивается. В Испании идея гуманного обращения с работниками обеспечила школе человеческих отношений поддержку католической церкви. В Германии протестанты поддержали систему научной организации труда, потому что она исходит из принципов индивидуализма и опоры на собственные силы. Новые практики не распространяются повсеместно; напротив, они появляются лишь там, где уже существуют совместимые с ними социальные институты и где управленческие системы способны проводить изменения. Эти результаты подтверждают верность замечания Вебера о том, что общественные институты, обладающие «избирательным сродством», поддерживают друг друга.

\section{Мари-Лор Джелич: копирование американской модели капитализма}

В книге «Экспорт американской модели: трансформация европейского бизнеса после войны» МариЛор Джелич [Djelic 1998] ставит вопрос о том, почему после Второй мировой войны заимствование капитализма «американского образца» удалось во Франции и Германии, но не получилось в Италии. Основной причиной таких различий стали особенности международных институтов и национальных политических институтов. Во Франции и Германии прижились корпоративная структура (а не отдельные независимые собственники) и разветвлённая (а не простая унитарная) форма организационного устройства, а также принудительная ценовая конкуренция (а не картельные соглашения). Также сыграла роль поддержка международных институтов (в форме помощи по плану Маршалла), местных политических систем и делового сообщества. В Италии же принятию американской модели помешали сопротивление изменениям со стороны промышленников и тот факт, что проводившие план Маршалла в жизнь администраторы были ориентированы на инфраструктурные проекты в ущерб развитию промышленности; также сыграла роль и несогласованность мер в рамках программы восстановления.

Для сравнительных и исторических исследований веберианского толка характерен акцент на смыслах, которыми акторы наделяют социальные конвенции, и на воздействии, оказываемом различными социальными институтами. Воспроизводство хозяйственных конвенций возможно лишь в той степени, в которой акторы понимают их смысл. Выполнение хозяйственных конвенций должно поддерживаться различными социальными институтами; в противном случае конвенции изменяются. Такие соображения выдвигал не только Вебер, но именно благодаря его трудам эта проблематика заняла центральное место в экономической социологии.

\section{Сети и роли: наследие Эмиля Дюркгейма}

\section{Изменения сетей и ролей}

Большинство экономсоциологов полагают, что хозяйственное поведение является по своей сути ролевым. Если экономисты-неоклассики считают, что хозяйственное поведение направляется индивидуальными расчетами, то экономсоциологи видят причину в нормативных предписаниях, налагаемых социальными ролями. Различия социальных сетей и социальных ролей в разных обществах изучал Эмиль Дюркгейм, и многие сравнительные и исторические исследования в экономической социологии основываются на его идеях. В рамках сетевого подхода в экономической социологии также получили развитие идеи Дюркгейма о воздействии конкретных социальных связей на хозяйственное поведение.

\section{Эмиль Дюркгейм: разделение труда}

Дюркгейм попытался объяснить возникновение промышленного капитализма исходя из конфигурации конкретных социальных сетей, приведшей к возрастанию разделения труда. Дюркгейм считал, что социальные сети обеспечивают индивидов набором ролей и сценариев поведения, которым те следуют 
в хозяйственной деятельности. В обществах, изученных Дюркгеймом, сети межличностных связей коренным образом различались: от тотемических племенных обществ в южной части Тихого океана до сложных индустриальных обществ в Европе начала XX века.

Особенностью современных обществ является разделение труда — ситуация, когда выполнение задач по поддержанию жизнедеятельности разделяется между членами общества. В работе «О разделении общественного труда» Дюркгейм рассматривает, каким образом индустриализация изменяет характер социальных привязанностей, как индивиды начинают ассоциировать себя с представителями своей профессиональной группы, а не просто со своим локальным сообществом [Durkheim 1933]. По мнению Дюркгейма, хозяйственная деятельность определяется социальной ролью, а ролевая идентичность в современных обществах формируется прежде всего по признаку профессиональной принадлежности. Люди соотносят себя с представителями своей профессии и действуют согласно сценариям и нормам этой профессии. Это означает, например, что поведение управленцев, врачей, бухгалтеров и уборщиков в повседневных ситуациях определяется хозяйственными обычаями, а не рациональным расчётом. Принятые в профессиональной группе конвенции могут основываться на рациональных соображениях, но за рутинными действиями стоит следование традиции, а не активный рациональный выбор.

\section{Вивиана Зелизер: изменение роли детей в промышленности}

Как происходит смена социальных ролей в современном обществе? Вивиана Зелизер показала, что усилия сторонников социальных реформ, объединённых сетевыми связями, привели к изменению роли детского труда в капиталистических обществах, переопределили рационализированные роли и образцы поведения [Zelizer 1987]. Согласно установившейся в раннекапиталистическом производстве практике почасовой оплаты труд детей покупался и продавался наравне с трудом взрослых. Дети рассматривались как работники всюду - в системе фабричного производства, в сфере страхования жизни, в приёмных семьях, в судопроизводстве. Задачей страхования жизни детей было возмещение упущенных доходов. Приёмные родители предпочитали принимать в семью мальчиков постарше, так как их труд ценился выше. Суды назначали родителям ребёнка, погибшего в результате несчастного случая, компенсацию, рассчитанную на основании его упущенных заработков.

Сторонники социальных реформ, объединённые сетевыми связями, стремились защитить детей от работы на производстве, изменив общественные представления о роли детей. Они описывали детство как сакральную категорию и убеждали родителей, что ценность детей является не экономической, а эмоциональной. Успех реформаторов можно оценить по масштабу институциональных изменений. Большинство видов детского труда были объявлены незаконными. Страхование жизни детей переориентировалось на возмещение моральных страданий родителям, скорбящим о потере ребёнка. Приёмные родители стали отдавать предпочтение маленьким девочкам: пусть они не могли стать хорошими работниками, но вызывали куда большую эмоциональную привязанность. Суды назначали скорбящим родителям компенсацию за эмоциональную утрату. В 1870-1930 гг. получили институциональное оформление новые нормы, регламентирующие роль детей в капиталистических отношениях. Работодатели сами начали говорить о том, что детям полезнее посещать школу, так как это лучше подготовит их к будущей работе. Такое изменение произошло благодаря тому, что социальное движение сделало популярной новую концепцию роли ребенка - новую рационализацию детства, в которой центральное место занимает обучение, а не труд.

\section{Джулия Адамс: проблема принципала-агента в голландских колониальных сетях}

Подобно Кизеру и Шнайдеру, Джулия Адамс заинтересовалась сбором доходов на этапе становления европейских государств и рассмотрела ситуацию с точки зрения проблемы принципала-агента 
[Adams 1996]. Сочетая сетевой подход и теорию агентских отношений, Адамс поддерживает тезис Дюркгейма о том, что человек зачастую подчиняется экономическим нормам под влиянием своей идентичности. Но на примере респектабельных торговых агентов голландской колониальной империи Адамс показывает, что одной идентичности иногда недостаточно. Поначалу метрополии с успехом удавалось возвращать прибыли, полученные торговыми сетями голландской Ост-Индской компании. Как полагает Адамс, это происходило благодаря тому, что у голландских торговых агентов в Азии не было альтернативной торговой сети. С развитием параллельной сети английской Ост-Индской компании у голландских агентов появился альтернативный торговый маршрут, многие из них перешли на положение свободных агентов и стали действовать ради собственного обогащения, а не в интересах своего принципала, то есть империи. Виной тому была низкая мотивация агентов к сохранению верности голландской торговой сети. Готовность британских агентов перейти к конкурентам оказалась не такой высокой, поскольку Британская империя снизила стимулы к выходу из сети. Таким образом, верность агентов империи зависела от структуры социальных сетей и способности этих сетей удерживать своих участников.

\section{Сети и экономическое развитие}

Положение в сети также задаёт роль нации в международном порядке. Это первым заметил Маркс и особенно подчёркивал Владимир Ленин в работе, посвящённой империализму [Lenin 1976 (1916)]. Среди современных работ особое внимание вызывают неодюркгеймианские исследования, в которых подчёркивается позитивное воздействие сильных социальных сетей на экономическое развитие [Putnam 1993]. Взаимосвязь сетей и развития я рассматриваю поэтому в разделе, посвящённом наследию Дюркгейма.

\section{Иммануил Валлерстайн: мир-система}

Как показано в масштабных исторических исследованиях Иммануила Валлерстайна, посвященных эволюции мир-системы, судьба стран, развитие которых началось позже, отличается от судьбы стран, ранее вставших на путь развития, отчасти потому, что создаваемая в них прибыль будет выводиться в более развитые страны [Wallerstein 1976-1980]. В модели Валлерстайна страны ядра покупают по низким ценам сырье и сельскохозяйственные товары у стран периферии. Власть, понимаемая как способность стран ядра вести войну и контролировать технологии, ставит периферийные страны в подчинённое положение. Исследования Валлерстайна напрямую наследуют работы Пола Барана, который тоже полагал, что путь развития страны зависит от её положения в глобальной торговой сети, а власть является ключевым фактором, позволяющим развитым странам извлекать стоимость из экономик менее развитых стран [Baran 1957; Baran, Sweezy 1966].

\section{Фернандо Кардозо и Энцо Фалетто: экономическая зависимость и индустриализация}

В работе Фернандо Кардозо и Энцо Фалетто «Зависимость и развитие в Латинской Америке» [Cardoso, Faletto 1979] рассматривается проблема экономической зависимости слаборазвитых стран от развитых. Кардозо, более известный как президент Бразилии в 1994-2002 гг., был в то же время заметным специалистом в области исследований развития в 1980-е гг. Как утверждал П. Баран, причиной задержки роста отстающих государств является то, что развитые страны извлекают стоимость из их экономик, покупая сырьё - сельскохозяйственную продукцию, древесину, нефть и другие полезные ископаемые - по низким ценам [Baran 1957]. Но концепция Барана была довольно примитивной.

Кардозо и Фалетто усовершенствовали эту идею, указав, что форма зависимости развивающейся страны от развитых (и, как следствие, структура производства) определяется классовой структурой раз- 
вивающейся страны. Принципиальное значение имеет то, как распределена власть между элитами внутри страны. Кардозо и Фалетто описывают разные модели встраивания местных классов в международное хозяйство; эти модели представляют собой типичные этапы эволюции зависимости. Вначале слои торговцев вовлекаются в экспорт сырья. Затем, по мере того как страна начинает экспортировать продукцию обрабатывающей промышленности, на сцену выходят городские средние классы и промышленная буржуазия. Когда происходит замещение импорта местными товарами, в производство вовлекаются более широкие слои населения. На каждом этапе форма отношений зависимой страны с ядром устанавливается при содействии местных элит: так, размещение инвесторами заводов по производству товаров на экспорт (export platform manufacturing) требует совершенно иных классовых отношений между странами, чем, например, добыча полезных ископаемых или производство древесины. Сети классовых отношений между странами определяют формат развития.

\section{Гэри Джереффи: стратегии международных корпораций и зависимое развитие}

Если Ф. Кардозо и Э. Фалетто выяснили, что структура экспортных отраслей в развивающихся странах задаётся характером межстрановых сетевых связей, то Гэри Джереффи выявил похожую зависимость структуры производства от мультинациональных корпораций, исследовав ситуацию в одной и той же отрасли в 14 странах [Gereffi 1983]. Используя сравнительный метод Дж. С. Милля, Джереффи обнаружил, что обладающие властью транснациональные корпорации, производящие стероиды, препятствовали созданию конкурирующих национальных предприятий в каждой из рассмотренных стран: власть транснациональных корпораций достаточна, чтобы подавить любых игроков национального уровня. Транснациональные корпорации господствуют в данной отрасли не в силу их эффективности, а потому что обладают рыночной властью и готовностью менять правила игры в свою пользу.

Работы Г. Джереффи и его соавторов сместили фокус сравнительных исследований развития, в них осуществлён переход от изучения зависимых стран к исследованию производственных сетей, или товаропроводящих цепей (commodity chains) [Gereffi, Korzeniewicz 1994]. Исследователи прослеживают путь товаров начиная с этапа добычи сырья и вплоть до конечного потребителя. По мере того как транснациональные корпорации осуществляют глобализацию производственных процессов во многих отраслях, товаропроводящие цепи усложняются и задействуют всё больше стран. Изучение отдельных отраслей показывает, что транснациональные корпорации пользуются тем, что в одних странах отсутствует регулирование добывающих отраслей, в других есть дешёвый труд, в третьих же имеются развитые технологии производства. Следуя концепции сравнительных преимуществ, корпорации на каждом этапе производственного процесса ищут места с самыми выгодными зарплатами, природоохранным законодательством и т. д.

\section{Питер Эванс: роль стратегий государства и сетей элиты в развивающихся странах}

Если сравнительные исследования хозяйственных систем в развитых странах показывают, что существует множество способов достичь процветания и экономический рост возможен при разном устройстве государства и промышленности, то сравнительные исследования развивающихся стран обычно обращают внимание на факторы, ускоряющие рост. Питер Эванс исследовал, каким образом сети бюрократов, транснациональных корпораций и местных капиталистов могут стимулировать развитие. Согласно общепринятой точке зрения рост происходит благодаря государственной политике laissez-faire. Эванс оспаривает эту идею в двух книгах, одна из которых посвящена преимущественно Бразилии («Зависимое развитие» [Evans 1979]), а другая сравнивает Бразилию с Южной Кореей и Индией («Укоренённая автономия» [Evans 1995]). Исследователь, во-первых, показывает, что почти во всех случаях успешного развития государство активно поддерживало промышленность. Это становится очевидным по итогам сравнения разных отраслей в Бразилии. Во-вторых, Эванс говорит о том, что государство 
должно быть автономным, то есть должно обладать бюрократическим аппаратом, изолированным от влияния военных и иных общественных групп, чтобы успешно проводить в жизнь стратегии роста. Тогда в соответствии с веберовской нормой рациональности государство становится эффективным менеджером хозяйства. Если капиталисты контролируют решения государственного аппарата, то динамичный рост маловероятен. В-третьих, для успешного развития государство должно быть встроено в общественные сети, чтобы получать информацию о ситуации в отрасли и сохранять способность воздействовать на неё. Это подтверждают результаты сравнения отраслей информационных технологий в Бразилии, Южной Корее и Индии: Южная Корея, яркий образец укоренённой автономии, достигла наибольшего успеха; в Бразилии и Индии успешное развитие также происходило именно в тех сегментах отрасли, где государство занимало правильную позицию. Для успешного развития необходимо, чтобы бюрократические правила предусматривали для разных групп общества возможность повлиять на действия государственного аппарата, но государство при этом должно активно содействовать развитию; а для эффективного содействия требуется, чтобы государственные элиты были встроены в сети предпринимателей и финансистов.

Исследования развития всё более отчётливо демонстрируют, как важно для достижения экономического роста наличие сильных социальных связей. Общества, не располагающие адекватным «социальным капиталом», оказываются в менее выгодном положении по сравнению с теми странами, где сложились большие и плотные сети.

\section{Роли и институты в переходных экономиках}

Переход к капиталистическому устройству в странах Восточной Европы, в республиках бывшего СССР и Китае стал своего рода лабораторией для изучения быстрых сдвигов в хозяйственных практиках. По-видимому, можно заключить, что разработанные Джеффри Саксом [Sachs 1989] и другими экономистами планы быстрого перехода через шоковую терапию провалились, и это привлекло значительный интерес к социологическому анализу переходных экономик. Сторонники шоковой терапии полагали, что для высвобождения рыночных сил достаточно уничтожить социалистические формы хозяйствования - такие, как коллективная собственность. Но социологический анализ показывает, что образующаяся пустота не может быть заполнена какой-то одной из уже существующих систем, будь то неолиберализм американского толка или японская система партнёрства между государством и бизнесом. Вебер по этому поводу сказал бы, что институты не так просто изменить. Дюркгейм сказал бы, что изучение социальных ролей и сетей часто позволяет объяснить ход изменений системы. В этом разделе будут рассмотрены лишь некоторые исследования 7

\section{Иван Селеньи: подъём буржуазии в условиях коммунистического режима}

Иван Селеньи описал возникновение протокапиталистических предприятий в Восточной Европе в 1989 г. ещё до падения социалистического режима. В книге Д. Конрада и И. Селеньи «Интеллектуалы на пути к классовой власти» [Konrád, Szelényi 1979] утверждалось, что в условиях современного социализма правящим классом становятся интеллектуалы. Однако уже в конце 1980-х гг. Селеньи и его коллеги обнаружили, что в Венгрии, вопреки всем ожиданиям, появилась новая буржуазная элита [Szelényi et al. 1988]. Эта элита состояла из фермеров, производящих сельскохозяйственные товары для сбыта на негосударственных рынках. Селеньи отмечает, что эти люди в большинстве своём происходили из семей, члены которых занимались предпринимательством ещё до установления в Венгрии коммунистического режима. Такие семьи на протяжении 40 лет сохраняли склонность к предпринимательству, и выходцы из них сумели создать активные и довольно успешные предприятия, занявшие

7 Обзор большинства работ по данной теме см.: [King, Szelényi 2005]. — Примеч. автора. 
нишу, образованную неудовлетворённым спросом на сельскохозяйственные товары на частных, не регулируемых государством рынках. Селеньи говорит о преемственности социальных ролей на уровне семьи. К 1944 г. часть семей в Венгрии превращались в буржуазный слой, и они, хотя были вынуждены на время оставить эти притязания, как только возникла частная «вторая экономика», вернулись к предпринимательской деятельности.

\section{Дэвид Старк: зависимость от траектории в постсоциалистических странах}

Для Дэвида Старка исследовательской лабораторией стала Восточная Европа после падения коммунистических режимов [Stark 1992a; 1992b; Stark, Bruszt 1998]. Его сравнительные исследования перехода к капитализму подтверждают, что хозяйственные институты возникают на основе институтов, существовавших ранее. Старк показал, что переход к капиталистическому устройству опосредуется экономическими и политическими институтами, сохранившимися с коммунистических времён. Традиция напоминает о себе даже тогда, когда страна целенаправленно стремится избавиться от наследия прошлого. В конечном счёте, потенциал экономического роста оказывается выше у обществ с прочными социальными сетями, стимулирующими участие в политическом процессе.

В исследовании стратегий приватизации после 1989 г. Старк оспаривает концепцию «капитализма по готовому рецепту», согласно которой по одному и тому же сценарию можно создать одинаковые капиталистические системы во всех странах. Проводя приватизацию в соответствии с таким «рецептом», разные страны построили очень разные системы, которые опираются на институты и предпосылки доприватизационного периода [Stark 1992b]. По решению государства акции государственных предприятий могли быть переданы либо корпорациям, либо частным лицам; кроме того, акции могли либо продавать, либо распределять между теми, кто, как считалось, имел право владеть ими. В Чехословакии и Польше акции передавались гражданам: в Чехословакии - через продажи на ваучерных аукционах, в Польше - через раздачу ваучеров гражданам. В Восточной Германии и Венгрии акции переходили к корпорациям. В бывшей ГДР — путём продажи, а в Венгрии - через юридическую реорганизацию предприятий, становившихся собственниками своих акций. Причина такого разнообразия в том, что в коммунистический период в этих странах существовали разные формы общественной собственности предприятий; кроме того, свою роль сыграла специфика структур сетевых связей в рамках элиты.

Какие меры следует принять в течение переходного периода, чтобы добиться экономического роста? В книге «Дороги после социализма» Дэвид Старк и Ласло Бруст показали, что структура социальных связей важнее, чем степень приближения к неолиберальной модели рынка [Stark, Bruszt 1998]. Предпосылкой успеха выступает устойчивость прав собственности, которая формируется на основе сетевых структур общества. Преемственность политики и экономический рост наблюдаются там, где складывается «совещательное объединение» (deliberative association) производителей, создающих открытый рынок, на котором у каждого участника есть право голоса. Примером может служить последовательная политика в Чешской Республике, резко контрастирующая с нестабильной политикой Венгрии.

\section{Виктор Ни: социальные роли и экономические стимулы при переходе к рынку в Китае}

Виктор Ни изучает, как в период перехода к капитализму в Китае интересы элит изменялись вслед за институциональными сдвигами в государственной политике, и оценивает воздействие этих изменений на процесс перехода [Nee 1989; 1991; 1992; 1996]. Ни полагает, что хозяйственные практики и структуры воспроизводятся благодаря созданному ими же балансу интересов, и что пересмотр государственной политики может изменить интересы и модели поведения хозяйственных субъектов. Когда государство принялось поощрять предпринимательскую инициативу, первыми предпринимателями стали сами государственные служащие, потому что они располагали необходимыми знаниями и имели до- 
ступ к ресурсам [Nee 1991]. Использование госслужащими своего привилегированного положения для ведения бизнеса поставило под угрозу легитимность партийного социализма, что ускорило переход к капиталистическому порядку [Nee 1996]. Таким образом, в результате смены создаваемых государственной политикой стимулов появились новые формы экономической деятельности, которые, в свою очередь, повлияли на политическую систему. Кроме того, от стимулов, возникающих в результате реализации той или иной политики, зависит, какие организационные формы будут развиваться в условиях капитализма. В статье «Организационная динамика при переходе к рынку» [Nee 1992] Ни показал, что в ходе переходного процесса в Китае не сложилась единая форма организации бизнеса, так как государство продолжало поддерживать гибридные формы - такие, как кооперативы и муниципальные предприятия. Причём эти формы оказались в состоянии конкурировать с частными предприятиями, организованными по западному образцу. Конкурентоспособность организационной формы зависела от того, является ли она эффективной в условиях данной государственной политики. Глубокое исследование, выполненное Ни, показывает, как важны при переходе к капитализму длительные социальные связи в среде высших государственных служащих.

\section{Дуелас Гатри: распространение американских управленческих практик в Китае}

В книге «Дракон в костюме-тройке: возникновение капитализма в Китае» Дуглас Гатри [Guthrie 1999] проследил трансформацию управленческих практик на китайских предприятиях на протяжении 1990-х гг, когда всё больше фирм принимали западную концепцию менеджмента. Не стоит говорить о том, что некая потребность в реформах спровоцировала переход предприятий на западную систему управления со свойственными ей бюрократической системой оплаты труда и продвижения по службе, рыночным ценообразованием, переориентацией на прибыльный сектор услуг и управлением на основании корпоративного законодательства. Вероятность смены управленческих практик на предприятии зависела от двух факторов иного рода. Прежде всего, это сетевые связи, особенно такие, которые способствовали распространению западных идей усилиями получивших соответствующее образование менеджеров или за счёт совместных предприятий с западными фирмами. Кроме того, быстро меняли практики управления те предприятия, которые ранее получали значительные субсидии от государства, но лишились этого источника средств. Таким образом, Гатри обнаружил, что появление новых стратегий корпораций в Китае лучше объясняет не теория эффективной организации, а институциональная теория, в рамках которой подчёркивается роль кризиса как катализатора перемен и рассматривается распространение новых стратегий через социальные сети.

Сравнительные и исторические исследования переходных процессов, вероятно, наилучшим образом демонстрируют возможности экономической социологии, поскольку используют лучшие из её концепций, заимствуя элементы из марксистской, веберианской и дюркгеймианской традиций.

\section{Заключение}

Карл Маркс, Макс Вебер и Эмиль Дюркгейм отмечали, что хозяйственные институты и обычаи значительно различаются в разные периоды истории и в разных обществах. Ученых интересовал вопрос о том, какие факторы отличают современные общества от традиционных, поэтому они сравнивали современные и традиционные общества, стремясь выявить причины возникновения рационального хозяйственного поведения. Поиск отличительных особенностей современности положил начало исторической экономической социологии. Хотя Маркс, Вебер и Дюркгейм существенно расходились в том, какой именно фактор стал источником возникновения современных хозяйственных обычаев - были ли то классовая борьба при феодализме, моральные нормы протестантизма или увеличение плотности населения и возрастание разделения труда, - все трое тем не менее считали, что хозяйственное поведение следует объяснять с точки зрения его социального контекста. Сталкиваясь с одними и теми же 
хозяйственными альтернативами, люди из разных обществ будут выбирать разные варианты действий, поскольку экономический выбор обусловлен социальной средой.

Экономсоциологи перешли от вопроса о происхождении современных моделей хозяйственного действия к вопросу о том, почему в современных обществах люди демонстрируют столь разные практики хозяйственного действия. Маркс, Вебер и Дюркгейм ещё не могли с уверенностью говорить о том, что современные общества будут столь же многообразными, как и античные, однако время показало, что в разных странах сложилось множество разнообразных моделей хозяйственного поведения. Япония, Тайвань и Южная Корея не только не похожи на Запад, но и отличаются друг от друга. Точно так же и западные страны не одинаковы с точки зрения хозяйственных институтов, обычаев и моделей поведения. В Германии, Франции, Великобритании, Швеции и США мы обнаруживаем фундаментальные различия в системах управления рабочей силой, в корпоративных стратегиях, в связях фирм в отрасли, в отношениях поставщиков и покупателей, в межотраслевых отношениях и во взаимодействии государства и бизнеса. В эпоху модерна здравый смысл подсказывал, что должен существовать единственный наилучший способ устройства каждой из этих сфер. Сравнительные исследования экономсоциологов показали, что способы организации этих сфер разнообразны, и, более того, многие из них обладают примерно одинаковой эффективностью. Но если эти страны не находятся на разных ступенях одной и той же лестницы в рай, на пути к совершенной рациональности, то как же объяснить различия между ними?

Для ответа на этот вопрос экономические социологи обратились к индуктивному сравнительному методу. Принятый метод является индуктивным, поскольку начальной точкой исследования служит набор теоретических гипотез, и необязательно исходить из того, что хозяйственная деятельность определяется каким-то одним фактором. Многие из рассмотренных в данной работе исследований поэтому сложно отнести к какому-то одному теоретическому направлению, ведь в них используются идеи, заимствованные из нескольких подходов. Применяемый метод является сравнительным, поскольку только с помощью сравнения можно понять, какие особенности данного общества привели к возникновению того или иного способа хозяйственной деятельности; например, к появлению диверсифицированных (intermarket) бизнес-групп, картелей или вертикально-интегрированных фирм. Исторические сравнения позволяют выявить факторы, предшествующие изменениям в хозяйственной деятельности; межстрановые сравнения могут указать на факторы, сопутствующие различным моделям хозяйственной деятельности.

Стоит отметить, что в целом экономические социологи не отказываются от представления о том, что хозяйственная деятельность связана со стремлением к большей эффективности. Но при этом несомненно то, что сегодня многие по-разному устроенные экономические системы одинаково эффективны, и поэтому задачей экономических социологов является объяснение такого разнообразия. Конечно, вопрос исчезновения отдельных моделей хозяйственной деятельности вследствие их неэффективности заслуживает изучения, однако всё же более удивительно другое: почему, по крайней мере до сих пор, существует такое множество различных способов действия?

Более чем за столетний период подобных индуктивных сравнительных исследований экономические социологи выявили три ключевых механизма, структурирующих хозяйственное поведение. Во-первых, это власть, задающая контуры хозяйственных институтов и конвенций. Маркс обнаружил, что появившаяся в условиях позднего феодализма буржуазия использовала новоприобретённые экономические ресурсы для изменения политики государства в выгодном для себя направлении, благоприятном для капиталистической деятельности. Современное государство декларирует нейтральность в экономических вопросах, но Маркс показал, что проводимая государством политика под видом стремления к общему благу создаёт преимущества для отдельных групп. В демократических странах властные 
группы зачастую приобретают возможность устанавливать «правила игры» для всех фирм, но государство и корпорации представляют эти правила как прогрессивные и направленные на повышение эффективности, а не на обслуживание интересов отдельных групп. Аналогичным образом Н. Флигстин продемонстрировал, что ориентированные на финансовые результаты менеджеры, которым удалось занять высшие управленческие посты в американских корпорациях, претендовали на то, что именно их компетенции позволяют наиболее эффективно решать проблемы современных фирм. У. Рой выяснил, что юридические правила, сделавшие корпорацию наиболее выгодной структурой управления, были пролоббированы конкретной группой капиталистов, которым удалось убедить общество в том, что принцип ограниченной ответственности и аналогичные юридические формы принесут пользу не только владельцам корпораций, но и обществу в целом. Власть часто предопределяет ход развития экономических институтов и обычаев, и эффективность использования властных ресурсов связана со способностью представить использование власти как деятельность на благо фирмы или страны.

Во-вторых, существующие хозяйственные институты и обычаи задают форму новых институтов и обычаев. Отчасти это происходит потому, что существующие институты предлагают модели устройства мира и ресурсы для организации новых областей деятельности, основываясь на том, как деятельность организовывалась ранее. Исторические исследования продемонстрировали не только резкие изменения хозяйственного поведения и институтов, но и то, что эти изменения происходят на основе прошлого опыта стран. Как установили Г. Гамильтон и Н. Биггарт, источником современных деловых стратегий в Японии, Южной Корее и Тайване стали не послевоенные инновации в промышленной политике, а стратегический выбор в пользу традиционных форм взаимодействия государства и бизнеса. Ф. Кардозо и Э. Фалетто выяснили, что развитие экспортно-ориентированного сектора в развивающихся странах зависит от характера классовых отношений в предшествующий период. Я обнаружил, что логика отношений государства и общества в доиндустриальном политическом устройстве США, Великобритании и Франции предопределила дальнейшее развитие отношений между государством и бизнесом.

Наконец, сети являются проводниками, по которым распространяются новые хозяйственные обычаи, и власть также реализуется через сети. Социальные сети принимают весьма разнообразные формы, и характер сети задаёт рамки возможного и невозможного в хозяйственной жизни. Дж. Дэвис и его соавторы показали: в 1970-е гг. объединённым сетевыми связями институциональным инвесторам удалось изменить правила корпоративной игры так, что диверсифицированным фирмам стало сложнее поддерживать высокие цены на активы, в результате чего произошло разделение этих фирм. В работах В. Ни описано, как сеть высокопоставленных государственных служащих повлияла на процесс перехода к капитализму в Китае, выступив в качестве предпринимателей. Согласно Б. Гао, одной из причин экономического кризиса 1990-х гг. в Японии было отсутствие формального контроля над деятельностью корпораций, обусловленное тесными связями между высокопоставленными чиновниками и корпорациями. Сети также задают социальные роли, которые исполняют их участники, и многие исследования показывают, что в хозяйственной жизни индивиды не раздумывая следуют социальным нормам вместо того, чтобы на каждом шагу углубляться в рациональные расчёты.

В работах авторов, использующих сравнительный и исторический подходы в экономической социологии для объяснения новых деловых практик или государственного вмешательства в промышленность, на первый план могут выдвигаться различные факторы из числа перечисленных, но всё чаще отмечается одновременное влияние всех трёх факторов [Fligstein 2001]. Если какой-либо институт национальной экономики или деловая практика получили распространение и начали восприниматься как наиболее эффективный способ организации данной сферы деятельности, то их смена обычно происходит лишь в критических обстоятельствах. Как правило, подобные шоковые обстоятельства запускают процесс соперничества между группами, придерживающимися разных взглядов на то, ка- 
кой должна быть новая политика или практика. В этот момент начинает действовать фактор власти: соперничающие группы стремятся с помощью риторики и имеющихся ресурсов добиться принятия выгодного им решения. Сети зачастую становятся площадкой для отработки новых практик и каналами распространения новой информации. Агенты, обладающие властью, используют свои сети, чтобы убедить остальных в эффективности выгодной им экономической политики или деловой практики, в результате чего институционализируется новая политика или практика, которая нередко позволяет избавиться от конкурентов. Так начинается новый цикл: в первое время меры государственной политики и деловые практики выглядят естественными, затем они сталкиваются с новыми вызовами и подвергаются сомнению, а группы влияния вступают в борьбу за право определить, какой будет дальнейшая политика и какие практики придут на смену прежним.

\section{Литература}

Adams J. 1996. Principals and Agents, Colonialists and Company Men: The Decay of Colonial Control in the Dutch East Indies. American Sociological Review. 61: 12-28.

Arthur W. B. 1988. Self-Reinforcing Mechanisms in Economics. In: Anderson P. W., Arrow K. J., Pines D. (eds) The Economy as an Evolving Complex System. New York: Wiley; 9-33.

Baran P. A. 1957. The Political Economy of Growth. New York: Monthly Review Press.

Baran P. A., Sweezy P. M. 1966. Monopoly Capital. New York: Modern Reader.

Bendix R. 1956. Work and Authority in Industry: Ideologies of Management in the Course of Industrialization. New York: John Wiley and Sons.

Biernacki R. 1995. The Fabrication of Labor: Germany and Britain, 1640-1914. Berkeley; Los Angeles: University of California Press.

Bloor D. 1976. Knowledge and Social Imagery. London: Routledge.

Budros A. 1997. The New Capitalism and Organizational Rationality: The Adoption of Downsizing Programs, 1979-1994. Social Forces. 76: 229-249.

Burawoy M. 1979. Manufacturing Consent: Changes in the Labor Process under Monopoly Capitalism. Chicago: University of Chicago Press.

Campbell J. L., Hollingsworth J. R., Lindberg L. N. (eds) 1991. Governance of the American Economy. Cambridge: Cambridge University Press.

Cardoso F. H., Faletto E. 1979. Dependency and Development in Latin America. Berkeley; Los Angeles: University of California Press.

Carruthers B. 1996. City of Capital: Politics and Markets in the English Financial Revolution. Princeton: Princeton University Press.

Chandler A. D., Jr. 1977. The Visible Hand: The Managerial Revolution in American Business. Cambridge: Harvard University Press. 
Cumings B. 1987. The Origins and Development of the Northeast Asian Political Economy: Industrial Sectors, Product Cycles, and Political Consequences. In: Deyo F. C. (ed.) Political Economy of the New Asian Industrialization. Ithaca, NY: Cornell University Press; 44-83.

David P. 1985. Clio and the Economics of QWERTY. American Economic Review. 75: 332-337.

Davis G. F., Diekman K., Tinsley C. H. 1994. The Decline and Fall of the Conglomerate Firm in the 1980s: The Deinstitutionalization of an Organizational Form. American Sociological Review. 59: 547-570.

Djelic M. 1998. Exporting the American Model: The Postwar Transformation of European Business. Oxford: Oxford University Press.

Dobbin F. 1993. The Social Construction of the Great Depression: Industrial Policy during the 1930s in the United States, Britain, and France. Theory and Society. 22: 1-56.

Dobbin F. 1994. Forging Industrial Policy: The United States, Britain and France in the Railway Age. Cambridge: Cambridge University Press.

Dobbin F., Dowd T. 2000. The Market that Antitrust Built: Public Policy, Private Coercion, and Railroad Acquisitions, 1825-1922. American Sociological Review. 65: 635-657.

Dore R. 1973. British Factory — Japanese Factory. Berkeley; Los Angeles: University of California Press.

Dore R. 2000. Stock Market Capitalism: Welfare Capitalism — Japan and Germany versus the Anglo-Saxons. Oxford: Oxford University Press.

Durkheim E. 1933. The Division of Labor in Society (trans. G. Simpson). New York: Free Press; см. также: Дюркгейм Э. 1996. О разделении общественного труда. Перев. с франц. А. Б. Гофмана. М.: Канон.

Durkheim E. 1982 (1938). The Rules of Sociological Method (trans. W. D. Halls). New York: Free Press.

Evans P. 1979. Dependent Developments: The Alliance of Multinational, State, and Local Capital in Brazil. Princeton: Princeton University Press.

Evans P. 1995. Embedded Autonomy: States and Industrial Transformation. Princeton: Princeton University Press.

Fligstein N. 1990. The Transformation of Corporate Control. Cambridge: Harvard University Press.

Fligstein N. 2001. The Architecture of Markets: The Economic Sociology of Twenty-first Century Capitalist Societies. Princeton: Princeton University Press.

Fligstein N., Markowitz L. 1993. Financial Reorganization of American Corporations in the 1980s. In: Wilson W. J. (ed.). Sociology and the Public Agenda. Beverly Hills, Calif.: Sage.

Gao B. 1997. Economic Ideology and Japanese Industrial Policy: Developmentalism between 1931 and 1965. Cambridge: Cambridge University Press. 
Gao B. 2001. Japan's Economic Dilemma: The Institutional Origins of Prosperity and Stagnation. Cambridge: Cambridge University Press.

Gereffi G. 1983. The Pharmaceutical Industry and Dependency in the Third World. Princeton: Princeton University Press.

Gereffi G., Korzeniewicz M. (eds) 1994. Commodity Chains and Global Capitalism. New York: Praeger.

Gorski P. S. 1993. The Protestant Ethic Revisited - Disciplinary Revolution and State Formation in Holland and Prussia. American Journal of Sociology. 99: 256-316.

Granovetter M. 1985. Economic Action and Social Structure: The Problem of Embeddedness. American Journal of Sociology. 91: 481-510.

Guillén M. F. 1994. Models of Management: Work, Authority, and Organization in a Comparative Perspective. Chicago: University of Chicago Press.

Guillén M. F. 2001. The Limits of Convergence: Globalization and Organizational Change in Argentina, South Korea, and Spain. Princeton: Princeton University Press.

Guthrie D. 1999. Dragon in a Three-Piece Suit: The Emergence of Capitalism in China. Princeton: Princeton University Press.

Hamilton G. G., Biggart N. W. 1988. Market, Culture, and Authority: A Comparative Analysis of Management and Organization in the Far East. American Journal of Sociology. 94: S52-S94.

Hofstede G. 1980. Culture's Consequences: International Differences in Work Values. Beverly Hills, Calif.: Sage.

Johnson C. 1982. MITI and the Japanese Miracle: The Growth of Industrial Policy, 1925-1975. Stanford, Calif.: Stanford University Press.

Kalleberg A. L., Lincoln J. R. 1988. The Structure of Earnings Inequality in the United States and Japan. American Journal of Sociology. 94: S121-S153.

Kimeldorf H. 1989. Reds or Rackets: The Making of Radical and Conservative Unions on the Waterfront. Berkeley; Los Angeles: University of California Press.

Kiser E., Schneider J. 1995. Bureaucracy and Efficiency: An Analysis of Taxation in Early Modern Prussia. American Sociological Review. 59: 187-204.

King L. P., Szelényi I. 2005. Post-Communist Economic Systems. In: Smelser N. J., Swedberg R. (eds) The Handbook of Economic Sociology. Princeton, NJ: Princeton University Press; 205-229.

Konrád G., Szelényi I. 1979. The Intellectuals on the Road to Class Power. Brighton: Harvester Press.

Lenin V. I. 1976 (1916). Imperialism, the Highest Stage of Capitalism. In: Lenin V. I. Selected Writings. New York: International Publishers; 169-263; см. также: Ленин В. И. 1969. Империализм как высшая ста- 
дия капитализма (популярный очерк). В изд.: Ленин В. И. Полн. собр. соч. Изд. 5-е: В 55 т. Т. 27. М.: Государственное издательство политической литературы; 299-426.

Lincoln J. R., Kalleberg A. L. 1985. Work Organization and Workforce Commitment: A Study of Plants and Employees in the U.S. and Japan. American Sociological Review. 50: 738-760.

Lincoln J. R. et al. 1990. Culture, Control, and Commitment: A Study of Work Organization and Work Attitudes in the United States and Japan. Cambridge: Cambridge University Press.

Marx K. 1994 (1867-1894). Das Kapital. 3 vols. New York: International Publishers; см. также: Маркс K. Капитал: Критика политической экономии. В изд.: Маркс К., Энгельс Ф. 1960-1964. Сочинения. Изд. 2-е: В 50 т. Т. 23-26. М.: Государственное издательство политической литературы.

Marx K. 1963 (1851-1852). The Eighteen Brumaire of Louis Bonaparte. New York: International Publishers; см. . также: Маркс К. Восемнадцатое брюмера Луи Бонапарта. В изд.: Маркс К., Энгельс Ф. 1957. Сочинения. Изд. 2-е: В 50 т. Т. 8. М.: Государственное издательство политической литературы; 115217.

Marx K. 1971 (1857). The Grundrisse (ed. and trans. D. McLellan). New York: Harper and Row; см. также: Маркс К., Энгельс Ф. 1968-1969. Сочинения. Изд. 2-е: В 50 т. Т. 46, ч. 1, 2. М.: Государственное издательство политической литературы.

Marx K. 1974 (1845-1846). The German Ideology. New York. International Publishers; см. также: Маркс K., Энгельс Ф. 1955. Немецкая идеология. Критика новейшей немецкой философии в лице ее представителей Фейербаха, Б. Бауэра и Штирнера и немецкого социализма в лице его различных пророков. В изд.: Маркс К., Энгельс Ф. Сочинения. Изд. 2-е: В 50 т. Т. 3; 7-544.

Marx K., Engels F. 1972 (1848). Manifesto of the Communist Party. In: Tucker R. C. (ed.) The Marx-Engels Reader. New York: W.W. Norton; 331-362; см. также: Маркс К., Энгельс Ф. 1955. Манифест Коммунистической партии. В изд.: Маркс К., Энгельс Ф. Сочинения. Изд. 2-е: В 50 т. Т. 4; 419-459.

Meyer J. W., Rowan B. 1977. Institutionalized Organizations: Formal Structure as Myth and Ceremony. American Journal of Sociology. 83: 340-363.

Mill J. S. 1974 (1888). A System of Logic. Ed. J. M. Robson. Toronto: University of Toronto Press.

Mintz B., Schwartz M. 1985. The Power Structure of American Business. Chicago: University of Chicago Press.

Nee V. 1989. A Theory of Market Transition: From Redistribuion to Markets in State Socialism. American Sociological Review. 54: 663-681.

Nee V. 1991. Social Inequalities in Reforming State Socialism: Between Redistribution and Markets in China. American Sociological Review. 56: 267-282.

Nee V. 1992. Organizational Dynamics of Market Transition: Hybrid Forms, Property Rights, and Mixed Economy in China. Administrative Science Quarterly. 37: 1-27.

Nee V. 1996. The Emergence of a Market Society: Changing Mechanisms of Stratification in China. American Journal of Sociology. 101: 908-949. 
Novak M. (ed.) 1993. The Catholic Ethic and the Spirit of Capitalism. New York: Free Press.

Orrù M., Biggart N. W., Hamilton G. 1991. Organizational Isomorphism in East Asia. In: Powell W., DiMaggio P. (eds) The New Institutionalism in Organizational Analysis. Chicago: University of Chicago Press; 361-389.

Ouchi W. G. 1981. Theory Z: How American Business Can Meet the Japanese Challenge. Reading, Mass.: Addison-Wesley.

Perrow C. 1992. Organizational Theorists in a Society of Organizations. International Sociology. 3: 371380.

Perrow C. 2002. Organizing America: Wealth, Power, and the Origins of Corporate Capitalism. Princeton: Princeton University Press.

Powell W., DiMaggio P. (eds) 1991. The New Institutionalism in Organizational Analysis. Chicago: University of Chicago Press.

Putnam R. D. 1993. Making Democracy Work: Civic Traditions in Modern Italy. Princeton: Princeton University Press.

Ragin C. 1987. The Comparative Method: Moving Beyond Qualitative and Quantitative Strategies. Berkeley; Los Angeles: University of California Press.

Roy W. G. 1997. Socializing Capital: The Rise of the Large Industrial Corporation in America. Princeton: Princeton University Press.

Sachs J. 1989. My Plan for Poland. International Economy. 3: 24-29.

Scott W. R. 1995. Institutions and Organizations. Thousand Oaks, Calif.: Sage.

Shenhav Y. 2000. Manufacturing Rationality: The Engineering Foundations of the Managerial Revolution. Oxford: Oxford University Press.

Skocpol T., Somers M. 1980. The Uses of Comparative History in Macrosocial Inquiry. Comparative Studies in Society and History. 22: 174-197.

Smelser N. 1976. Comparative Method in the Social Sciences. Englewood Cliffs, NJ: Prentice-Hall.

Smelser N. J., Swedberg R. 2005. Introducing New Economic Sociology. In: Smelser N. J., Swedberg R. (eds). The Handbook of Economic Sociology. Princeton, NJ: Princeton University Press; 3-25.

Stark D. 1992a. From System Identity to Organizational Diversity: Analyzing Social Change in Eastern Europe. Contemporary Sociology. 21: 299-304.

Stark D. 1992b. Path Dependence and Privatization Strategies in East Central Europe. East European Politics and Societies. 6: 17-51.

Stark D., Bruszt L. 1998. Postsocialist Pathways: Transforming Politics and Property in East Central Europe. Cambridge: Cambridge University Press. 
Streeck W. 1992. Social Institutions and Economic Performance: Studies of Industrial Relations in Advanced Capitalist Economies. Newbury Park, Calif.: Sage.

Swedberg R. 1998. Max Weber and the Idea of Economic Sociology. Princeton: Princeton University Press.

Swedberg R. 2001. Max Weber's Vision of Economic Sociology. In: Granovetter M., Swedberg R. (eds) The Sociology of Economic Life. Boulder: Westview.

Szelényi I. 1983. Urban Inequalities under State Socialism. Oxford: Oxford University Press.

Szelényi I. et al. 1988. Socialist Entrepreneurs: Embourgeoisement in Rural Hungary. Madison: University of Wisconsin Press.

Useem M. 1984. The Inner Circle. Oxford: Oxford University Press.

Useem M. 1996. Investor Capitalism: How Money Managers are Changing the Face of Corporate America. New York: Basic Books.

Wallerstein I. 1976-1980. The Modern World-System. Vols. 1-2. New York: Academic.

Weber M. 1951 (1916). The Religion of China: Confucianism and Taoism (trans. H. H. Gerth). Glencoe, Ill.: Free Press.

Weber M. 1952 (1917). Ancient Judaism (trans. H. H. Gerth, D. Martindale). Glencoe, Ill.: Free Press.

Weber M. 1958 (1916). The Religion of India: The Sociology of Hinduism and Buddhism (trans. H. H. Gerth, D. Martindale). Glencoe, Ill.: Free Press.

Weber M. 1963 (1922). The Sociology of Religion (trans. E. Fischolff). Boston: Beacon.

Weber M. 1978 (1922) Economy and Society (eds. G. Roth, C. Wittich). 2 vols. Berkeley: Los Angeles: University of California Press.

Weber M. 2002 (1905). The Protestant Ethic and the Spirit of Capitalism (trans. S. Kalberg). Los Angeles: Roxbury; см. также: Вебер М. 1990. Протестантская этика и дух капитализма. В кн.: Вебер М. Избранные произведения: Пер. с нем. П. П. Гайденко. М.: Прогресс; 44-272.

Westney E. 1987. Imitation and Innovation: The Transfer of Western Organizational Forms to Meiji Japan. Cambridge: Harvard University Press.

Whitley R. 1992a. Business Systems in East Asia: Firms, Markets, and Societies. London: Sage.

Whitley R. (ed.) 1992b. European Business Systems: Firms and Markets in Their National Contexts. London: Sage.

Whitley R., Kristensen P. H. (eds) 1996. The Changing European Firm: Limits to Convergence. New York: Routledge.

Wuthnow R. 2005. New Directions in the Study of Religion and Economic Life. In: Smelser N. J., Swedberg R. (eds) The Handbook of Economic Sociology. Princeton, NJ: Princeton University Press; 603-626. 
Williamson O.E. 1985. The Economic Institutions of Capitalism. New York: Free Press.

Woolcock M. 1998. Social Capital and Economic Development: Toward a Theoretical Synthesis and Policy Framework. Theory and Society. 27: 151-208.

Zelizer V. A. 1987. Pricing the Priceless Child: The Changing Social Value of Children. New York: Basic. 


\section{NEW TRANSLATIONS}

\section{Frank Dobbin}

\section{Comparative and Historical Perspectives in Economic Sociology}

DOBBIN, Frank — Professor, Department of Sociology, Harvard University. Address: 530 William James Hall, 33 Kirkland Street, Cambridge, MA 02138, USA.

Email: frank_dobbin@harvard.edu

Translated into Russian by Ekaterina Golovlyanitsyna.

Edited by Vadim Radaev, Greg Yudin.

Source: Dobbin F. (2005).

Comparative and Historical Approaches to Economic Sociology. The Handbook of Economic Sociology (eds. N. J. Smelser, R. Swedberg), Princeton: Princeton University Press, pp. 26-48.

\begin{abstract}
This paper reviews historical and comparative theories in economic sociology that seek to explain substantial differences in economic behavior across time and space. In order to develop a more integrative analytical framework, one should avoid the stance of mainstream economics that states a force of self-interest determines economic behavior exogenously. The author challenges the idea of a universal economic system and shows that most sociologists share the view that a society's structural, political, and cultural features shape economic behavior. However, scholars have not reached a consensus on a predominant explanation: some researchers focus on the role of social networks, others on power relations, and still others on social institutions-conventions. Originally, comparative and historical inquiry viewed these perspectives as alternative frameworks, but recent studies refer to them as complementary. Using the reasoning of three major predecessors to economic sociology - Karl Marx, Max Weber, and Emile Durkheim - the author categorizes modern comparative research in economic sociology in accordance with their theoretical toolkit. Despite all the differences, these studies apply the same inductive method, implying that a single process cannot account for variety in economic behavior.
\end{abstract}

Journal of Economic Sociology offers the Russian translation of the paper which was first published in The Handbook of Economic Sociology (2005).

Keywords: comparative approach; historical approach; inductive reasoning; power; institutions; networks.

\section{Acknowledgements}

Thanks to Richard Swedberg, Neil Smelser, Joseph Maning, Bruce Carruthers and Fred Block for comments and suggestions.

\section{References}

Adams J. (1996) Principals and Agents, Colonialists and Company Men: The Decay of Colonial Control in the Dutch East Indies. American Sociological Review, vol. 61, no 1, pp. 12-28.

Arthur W. B. (1988) Self-Reinforcing Mechanisms in Economics. The Economy as an Evolving Complex System (eds. P. W. Anderson, K. J. Arrow, D. Pines), New York: Wiley, pp. 9-33. 
Baran P. A. (1957) The Political Economy of Growth, New York: Monthly Review Press.

Baran P. A., Sweezy P. M. (1966). Monopoly Capital, New York: Modern Reader.

Bendix R. (1956) Work and Authority in Industry: Ideologies of Management in the Course of Industrialization, New York: John Wiley and Sons.

Biernacki R. (1995). The Fabrication of Labor: Germany and Britain, 1640-1914, Berkeley; Los Angeles: University of California Press.

Bloor D. (1976) Knowledge and Social Imagery, London: Routledge.

Budros A. (1997) The New Capitalism and Organizational Rationality: The Adoption of Downsizing Programs, 1979-1994. Social Forces, vol. 76, no 1, pp. 229-249.

Burawoy M. (1979). Manufacturing Consent: Changes in the Labor Process under Monopoly Capitalism, Chicago: University of Chicago Press.

Campbell J. L., Hollingsworth J. R., Lindberg L. N. (eds) (1991) Governance of the American Economy, Cambridge: Cambridge University Press.

Cardoso F. H., Faletto E. (1979) Dependency and Development in Latin America, Berkeley; Los Angeles: University of California Press.

Carruthers B. (1996) City of Capital: Politics and Markets in the English Financial Revolution, Princeton: Princeton University Press.

Chandler A. D., Jr. (1977) The Visible Hand: The Managerial Revolution in American Business, Cambridge: Harvard University Press.

Cumings B. (1987). The Origins and Development of the Northeast Asian Political Economy: Industrial Sectors, Product Cycles, and Political Consequences. Political Economy of the New Asian Industrialization (ed. F. C. Deyo), Ithaca, NY: Cornell University Press, pp. 44-83.

David P. (1985). Clio and the Economics of QWERTY. American Economic Review, vol. 75, no 2, pp. 332337.

Davis G. F., Diekman K., Tinsley C. H. (1994) The Decline and Fall of the Conglomerate Firm in the 1980s: The Deinstitutionalization of an Organizational Form. American Sociological Review, vol. 59, no 4, pp. 547-570.

Djelic M. (1998) Exporting the American Model: The Postwar Transformation of European Business, Oxford: Oxford University Press.

Dobbin F. (1993) The Social Construction of the Great Depression: Industrial Policy during the 1930s in the United States, Britain, and France. Theory and Society, vol. 22, no 1, pp. 1-56.

Dobbin F. (1994) Forging Industrial Policy: The United States, Britain and France in the Railway Age, Cambridge: Cambridge University Press. 
Dobbin F., Dowd T. (2000). The Market That Antitrust Built: Public Policy, Private Coercion, and Railroad Acquisitions, 1825-1922. American Sociological Review, vol. 65, no 65, pp. 635-657.

Dore R. (1973) British Factory - Japanese Factory, Berkeley; Los Angeles: University of California Press.

Dore R. (2000) Stock Market Capitalism: Welfare Capitalism - Japan and Germany versus the Anglo-Saxons, Oxford: Oxford University Press.

Durkheim E. (1933) The Division of Labor in Society, New York: Free Press.

Durkheim E. (1982) The Rules of Sociological Method, New York: Free Press.

Evans P. (1979) Dependent Developments: The Alliance of Multinational, State, and Local Capital in Brazil, Princeton: Princeton University Press.

Evans P. (1995) Embedded Autonomy: States and Industrial Transformation, Princeton: Princeton University Press.

Fligstein N. (1990) The Transformation of Corporate Control, Cambridge: Harvard University Press.

Fligstein N. (2001) The Architecture of Markets: The Economic Sociology of Twenty-first Century Capitalist Societies, Princeton: Princeton University Press.

Fligstein N., Markowitz L. (1993) Financial Reorganization of American Corporations in the 1980s. Sociology and the Public Agenda (ed. W. J. Wilson), Beverly Hills, Calif.: Sage, pp. 185-207.

Gao B. (1997) Economic Ideology and Japanese Industrial Policy: Developmentalism between 1931 and 1965, Cambridge: Cambridge University Press.

Gao B. (2001) Japan's Economic Dilemma: The Institutional Origins of Prosperity and Stagnation, Cambridge: Cambridge University Press.

Gereffi G. (1983) The Pharmaceutical Industry and Dependency in the Third World, Princeton: Princeton University Press.

Gereffi G., Korzeniewicz M. (eds) (1994) Commodity Chains and Global Capitalism, New York: Praeger.

Gorski P. S. (1993). The Protestant Ethic Revisited - Disciplinary Revolution and State Formation in Holland and Prussia. American Journal of Sociology, vol. 99, no 2, pp. 256-316.

Granovetter M. (1985) Economic Action and Social Structure: The Problem of Embeddedness. American Journal of Sociology, vol. 91, no 3, pp. 481-510.

Guillén M. F. (1994) Models of Management: Work, Authority, and Organization in a Comparative Perspective, Chicago: University of Chicago Press.

Guillén M. F. (2001) The Limits of Convergence: Globalization and Organizational Change in Argentina, South Korea, and Spain, Princeton: Princeton University Press. 
Guthrie D. (1999) Dragon in a Three-Piece Suit: The Emergence of Capitalism in China, Princeton: Princeton University Press.

Hamilton G. G., Biggart N. W. (1988) Market, Culture, and Authority: A Comparative Analysis of Management and Organization in the Far East. American Journal of Sociology, vol. 94, pp. S52-S94.

Hofstede G. (1980) Culture's Consequences: International Differences in Work Values, Beverly Hills, Calif: Sage.

Johnson C. (1982) MITI and the Japanese Miracle: The Growth of Industrial Policy, 1925-1975, Stanford, Calif.: Stanford University Press.

Kalleberg A. L., Lincoln J. R. (1988). The Structure of Earnings Inequality in the United States and Japan. American Journal of Sociology, vol. 94, pp. S121-S153.

Kimeldorf H. (1989) Reds or Rackets: The Making of Radical and Conservative Unions on the Waterfront, Berkeley; Los Angeles: University of California Press.

Kiser E., Schneider J. (1995) Bureaucracy and Efficiency: An Analysis of Taxation in Early Modern Prussia. American Sociological Review, vol. 59, no 2, pp. 187-204.

King L. P., Szelényi I. (2005) Post-Communist Economic Systems. The Handbook of Economic Sociology (eds. N. J. Smelser, R. Swedberg), Princeton, NJ: Princeton University Press, pp. 205-229.

Konrád G., Szelényi I. (1979) The Intellectuals on the Road to Class Power, Brighton: Harvester Press.

Lenin V. I. (1976 [1916]) Imperialism, the Highest Stage of Capitalism. Lenin V. I. Selected Writings, New York: International Publishers, pp. 169-263.

Lincoln J. R., Kalleberg A. L. (1985) Work Organization and Workforce Commitment: A Study of Plants and Employees in the U.S. and Japan. American Sociological Review, vol. 50, pp. 738-760.

Lincoln J. R., Kalleberg A. L., Hanada M., McBride K. (1990) Culture, Control, and Commitment: A Study of Work Organization and Work Attitudes in the United States and Japan, Cambridge: Cambridge University Press.

Marx K. (1994 [1867-1894]) Das Kapital. 3 vols. New York: International Publishers.

Marx K. (1963 [1851-1852]) The Eighteen Brumaire of Louis Bonaparte. New York: International Publishers.

Marx K. (1971 [1857]) The Grundrisse (ed. and trans. D. McLellan), New York: Harper and Row.

Marx K. (1974 [1845-1846]) The German Ideology, New York: International Publishers.

Marx K., Engels F. (1972 [1848]) Manifesto of the Communist Party. The Marx-Engels Reader (ed. R. C. Tucker), New York: W. W. Norton, pp. 331-362.

Meyer J. W., Rowan B. (1977) Institutionalized Organizations: Formal Structure as Myth and Ceremony. American Journal of Sociology, vol. 83, no 2, pp. 340-363. 
Mill J. S. (1974 [1888]) A System of Logic (ed. J. M. Robson), Toronto: University of Toronto Press.

Mintz B., Schwartz M. (1985) The Power Structure of American Business, Chicago: University of Chicago Press.

Nee V. (1989) A Theory of Market Transition: From Redistribuion to Markets in State Socialism. American Sociological Review, vol. 54, no 5, pp. 663-681.

Nee V. (1991) Social Inequalities in Reforming State Socialism: Between Redistribution and Markets in China. American Sociological Review, vol. 56, no 3, pp. 267-282.

Nee V. (1992) Organizational Dynamics of Market Transition: Hybrid Forms, Property Rights, and Mixed Economy in China. Administrative Science Quarterly, vol. 37, no 1, pp. 1-27.

Nee V. (1996) The Emergence of a Market Society: Changing Mechanisms of Stratification in China. American Journal of Sociology, vol. 101, no 4, pp. 908-949.

Novak M. (ed.) (1993) The Catholic Ethic and the Spirit of Capitalism, New York: Free Press.

Orrù M., Biggart N. W., Hamilton G. (1991) Organizational Isomorphism in East Asia. The New Institutionalism in Organizational Analysis (eds W. Powell, P. DiMaggio), Chicago: University of Chicago Press, pp. 361-389.

Ouchi W. G. (1981) Theory Z: How American Business Can Meet the Japanese Challenge, Reading, Mass.: Addison-Wesley.

Perrow C. (1992) Organizational Theorists in a Society of Organizations. International Sociology, vol. 7, no 3, pp. 371-380.

Perrow C. (2002) Organizing America: Wealth, Power, and the Origins of Corporate Capitalism, Princeton: Princeton University Press.

Powell W., DiMaggio P. (eds) (1991) The New Institutionalism in Organizational Analysis, Chicago: University of Chicago Press.

Putnam R. D. (1993) Making Democracy Work: Civic Traditions in Modern Italy, Princeton: Princeton University Press.

Ragin C. (1987) The Comparative Method: Moving Beyond Qualitative and Quantitative Strategies, Berkeley; Los Angeles: University of California Press.

Roy W. G. (1997) Socializing Capital: The Rise of the Large Industrial Corporation in America, Princeton: Princeton University Press.

Sachs J. (1989) My Plan for Poland. International Economy, vol. 3, no 6, pp. 24-29.

Scott W. R. (1995) Institutions and Organizations, Thousand Oaks, Calif.: Sage.

Shenhav Y. (2000) Manufacturing Rationality: The Engineering Foundations of the Managerial Revolution, Oxford: Oxford University Press. 
Skocpol T., Somers M. (1980) The Uses of Comparative History in Macrosocial Inquiry. Comparative Studies in Society and History, vol. 22, no 2, pp. 174-197.

Smelser N. (1976) Comparative Method in the Social Sciences, Englewood Cliffs, NJ: Prentice-Hall.

Smelser N. J., Swedberg R. (2005) Introducing New Economic Sociology. The Handbook of Economic Sociology (eds. N. J. Smelser, R. Swedberg). Princeton, NJ: Princeton University Press, pp. 3-25.

Stark D. (1992a) From System Identity to Organizational Diversity: Analyzing Social Change in Eastern Europe. Contemporary Sociology, vol. 21, no 3, pp. 299-304.

Stark D. (1992b) Path Dependence and Privatization Strategies in East Central Europe. East European Politics and Societies, vol. 6, no 1, pp. 17-51.

Stark D., Bruszt L. (1998) Postsocialist Pathways: Transforming Politics and Property in East Central Europe, Cambridge: Cambridge University Press.

Streeck W. (1992) Social Institutions and Economic Performance: Studies of Industrial Relations in Advanced Capitalist Economies, Newbury Park, Calif.: Sage.

Swedberg R. (1998) Max Weber and the Idea of Economic Sociology, Princeton: Princeton University Press.

Swedberg R. (2001) Max Weber's Vision of Economic Sociology. The Sociology of Economic Life (eds M. Granovetter, R. Swedberg), Boulder: Westview.

Szelényi I. (1983) Urban Inequalities under State Socialism, Oxford: Oxford University Press.

Szelényi I., Manchin R., Juhász P., Magyar B., Martin B. (1988) Socialist Entrepreneurs: Embourgeoisement in Rural Hungary, Madison: University of Wisconsin Press.

Useem M. (1984) The Inner Circle, Oxford: Oxford University Press.

Useem M. (1996) Investor Capitalism: How Money Managers are Changing the Face of Corporate America, New York: Basic Books.

Wallerstein I. (1976-1980) The Modern World-System. Vols. 1-2, New York: Academic.

Weber M. (1951 [1916]) The Religion of China: Confucianism and Taoism (trans. H. H. Gerth), Glencoe, Ill.: Free Press.

Weber M. (1952 [1917]) Ancient Judaism (trans. H. H. Gerth, D. Martindale), Glencoe, Ill.: Free Press.

Weber M. (1958 [1916]) The Religion of India: The Sociology of Hinduism and Buddhism (trans. H. H. Gerth, D. Martindale), Glencoe, Ill.: Free Press.

Weber M. (1963 [1922]) The Sociology of Religion (trans. E. Fischolff), Boston: Beacon.

Weber M. (1978 [1922]) Economy and Society (eds G. Roth, C. Wittich). 2 vols., Berkeley; Los Angeles: University of California Press. 
Weber M. (2002 [1905]) The Protestant Ethic and the Spirit of Capitalism (trans. S. Kalberg), Los Angeles: Roxbury.

Westney E. (1987) Imitation and Innovation: The Transfer of Western Organizational Forms to Meiji Japan, Cambridge: Harvard University Press.

Whitley R. (1992a) Business Systems in East Asia: Firms, Markets, and Societies, London: Sage.

Whitley R. (ed.) (1992b). European Business Systems: Firms and Markets in Their National Contexts, London: Sage.

Whitley R., Kristensen P. H. (eds) (1996) The Changing European Firm: Limits to Convergence, New York: Routledge.

Wuthnow R. (2005) New Directions in the Study of Religion and Economic Life. The Handbook of Economic Sociology (eds. N. J. Smelser, R. Swedberg), Princeton, NJ: Princeton University Press, pp. 603-626.

Williamson O. E. (1985) The Economic Institutions of Capitalism, New York: Free Press.

Woolcock M. (1998) Social Capital and Economic Development: Toward a Theoretical Synthesis and Policy Framework. Theory and Society, vol. 27, no 2, pp. 151-208.

Zelizer V. A. (1987). Pricing the Priceless Child: The Changing Social Value of Children, New York: Basic.

Received: April 15, 2016.

Citation: Dobbin F. (2016) Sravnitel'nyy i istoricheskiy podkhody v ekonomicheskoy sotsiologii [Comparative and Historical Approaches to Economic Sociology]. Journal of Economic Sociology = Ekonomicheskaya sotsiologiya, vol. 17, no 3, pp. 37-81. Available at: https://ecsoc.hse.ru/2016-17-3.html (in Russian). 


\section{ДЕБЮТНЫЕ РАБОТЫ}

\section{Е. О. Цыплакова}

\section{Геймификация - мотивационная практика или механизм тотального контроля над трудовым процессом?}

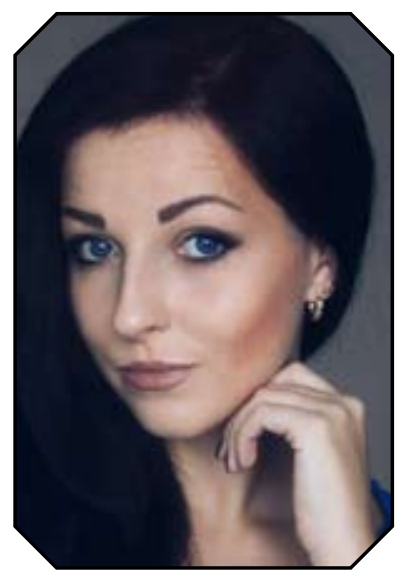

ЦЫПЛАКОВА Елена Олеговна - ведущий аналитик по продукту компании «Фабрика Лояльности». Адрес: 197110, Россия, Санкт-Петербург, пр. Чкаловский, д. 15.

Email: tsyplakova_ elena@mail.ru
В данной работе представлень результаты сочиологического исследования ${ }^{1}$, целью которого являлся анализ геймификаџии как инструмента контроля над трудовым проиессом. В рамках постфордизма и неофордизма, на примере геймификации изучено, как сочетаются мотивирующие игровые элементы и электронное принуждение. При этом в духе традиций индустриальной социологии особое внимание уделено усилению контроля над работниками, а также сочииальным и трудовым конфликтам.

Исследование представляет собой кейс, где источником информачии стали интервью с менеджерами и работниками российской компании, производящей алкогольные напитки. В исследовании с применением методологии обоснованной теории, с открытым, осевым и выборочным кодированием по фокусам 16 интервью описана специфика геймификаџии как новой управленческой практики.

Положительной стороной внедрения геймификаџии оказалось то, что виртуальная система поощрения в совокупности со стремлением к победе способствует повымению вовлечённости работников и идентификации их целей с иелью организации. В основном внедрение геймификации не повлекло возникновения открытых конфликтов между руководством и работниками, однако изменения в организаџии трудового процесса и технические трудности вызвали пассивные практики сопротивления новым условиям труда. Также отрииательной стороной оказалось ухудшение соииального климата в коллективе из-за обострённой конкуренции между работниками.

В итоге было вылвлено, что геймификаџия позиционируется как способ мотивации персонала, но в действительности является в первую очередь способом тотального контроля над трудовым процессом, организованного за счёт автоматизаџии труда работников и электронного мониторинга. При этом отличительная особенность этого способа - наличие игрового элемента, призванного разнообразить рутинную деятельность и завуалировать отрицательные стороны общего механизма.

Статья написана на основе магистерской диссертации «Геймификация как механизм мотивации труда и контроля над трудовым процессом (кейс компании-производителя алкогольной продукции)», выполненной на факультете социологии НИУ ВШЭ в 2015 г. Научный руководитель - А. В. Шевчук, к.э.н., доцент кафедры экономической социологии, старший научный сотрудник ЛЭСИ НИУ ВШЭ. 
Ключевые слова: геймификация; мотивация труда; трудовой процесс; контроль над работниками; электронное принуждение; электронный мониторинг.

\section{Введение}

Становление информационного общества характеризуется противоречивыми тенденциями в сфере мотивации труда и контроля над трудовым процессом, которые могут быть концептуализированы в рамках постфордизма и неофордизма [Шевчук 2002].

С одной стороны, повышение образовательного уровня работника и стремления к самовыражению в труде [Иноземцев 1997: 19] ставит перед фирмами задачу отхода от жёстких управленческих схем в духе Ф. Тейлора и Г. Форда. Работодателям приходится заботиться о новой философии управления, о всё более изощрённых методах мотивации труда и развития корпоративной культуры в русле постфордизма [Инглхарт, Вельцель 2011].

С другой стороны, развитие информационно-коммуникационных технологий даёт менеджменту новые возможности контроля над трудовым процессом за счёт автоматизации и алгоритмизации операций, а также электронного мониторинга за деятельностью работников. Подобные практики могут быть обозначены как неофордистские, поскольку в их рамках происходит не преодоление фордистских методов, а, наоборот, их упрочнение на новой технологической основе.

Одной из новых управленческих практик, лежащих в русле этих изменений, является геймификация (gamification), то есть применение игровых механик в неигровых процессах [Зикерманн, Линдер 2014: 5]. В контексте трудовых отношений геймификация подразумевает влияние на трудовое поведение работников через вовлечение их в игру: при помощи корпоративного программного обеспечения (приложения или социальной сети) сотрудникам определённой компании предлагается выполнение различных заданий и прохождение онлайн-квестов, связанных непосредственно с компанией и рабочим процессом, при этом всё взаимодействие между сотрудниками обязательно построено на конкурентной борьбе. В процессе игры работники получают виртуальное вознаграждение, которое может конвертироваться в продукцию данной компании либо в продукцию компаний-партнёров ${ }^{2}$.

На сегодняшний день геймификация рассматривается преимущественно в рамках управленческой литературы с соответствующим акцентом на эффективности этой методики с точки зрения управления персоналом (см., например: [Given 2011; Kapp 2012]). При этом социологический анализ геймификации как инструмента контроля над трудовым процессом может дать интересные и полезные результаты. За счёт каких социальных процессов геймификация влияет на трудовое поведение? С радостью ли работники принимают новые правила игры или воспринимают их как навязанные, вырабатывая стратегии сопротивления? Действительно ли работники эмоционально вовлечены в процесс игры или же их участие, скорее, формально? Являются ли виртуальные поощрения действенными мотиваторами по сравнению с традиционными денежными поощрениями? Важно ли признание игровых достижений коллегами? Как сказывается новая игра, построенная на принципах конкуренции, на отношениях в коллективе? Эти и другие подобные вопросы мы затронем в данной работе.

Исследование геймификации как новой управленческой практики является актуальным, так как позволяет глубже разобраться в сложных механизмах мотивации труда и трудовых отношений в современной экономике. Мы постараемся определить, как в рамках геймификации сочетаются мотивирующие игровые элементы (в русле постфордизма) и электронное принуждение (в русле неофордизма)

2 Например, накопленные в такой игре баллы можно обменять на сувенирную продукцию компании, на реальную продукцию компании или на сертификаты магазинов компаний-партнёров. 
[Sewell 1998]. При этом в духе традиций индустриальной социологии особое внимание будет уделено «оборотной стороне» столь привлекательной на первый взгляд игры - усилению контроля над работниками, социальным и трудовым конфликтам.

Для наилучшего понимания феномена геймификации на российском рынке труда идеальным вариантом было бы подробное изучение реальных игр, которые компании использовали для создания геймифицированного способа управления сотрудниками. Однако подобная информация конфиденциальна, и описание устройства геймифицированного механизма держит каждая компания в секрете. Тем не менее общую информацию о том, какие компании и в какой сфере используют геймификацию, всё же можно найти на сайтах компаний-разработчиков геймифицированных продуктов. Так, например, известно, что в России для управления сотрудниками геймификацию в той или иной степени используют «Юлмарт», «Теле2», «МТС», «Одноклассники», «Бэби.ру»³, государственная корпорация «Росатом», «М.Видео», «T-Systems CIS Россия», «Microsoft», «Qiwi», банк «Восточный экспресс» ${ }^{4}$ и многие другие.

Таким образом, проблема данного исследования заключается в выявлении воздействия геймифицированных инструментов на трудовое поведение работников и отношения в коллективе. Соответственно цель данного исследования - социологический анализ геймификации как инструмента контроля над трудовым процессом.

Объектом исследования являются следующие сотрудники компании, производящей алкогольные напитки: (1) менеджеры, разрабатывающие систему геймификации, внедряющие её и оценивающие результаты; (2) сотрудники, охваченные системой геймификации.

В качестве предмета исследования выступают управленческие практики и изменения в трудовом поведении работников в процессе внедрения геймификации в трудовой процесс.

Для достижения поставленной цели обозначен ряд вопросов, которые будут раскрыты в рамках данного исследования:

— Каковы механизм действия и составные элементы геймификации как новой управленческой практики?

- Каково воздействие геймификации на мотивацию и удовлетворённость трудом в организации и каковы изменения в отношении к выполнению профессиональных обязанностей?

- Присутствуют ли при внедрении геймификации практики активного и пассивного сопротивления работников? Есть ли трудовые конфликты и как достигаются компромиссы?

- Каким образом геймификация влияет на социальные отношения внутри коллектива, на конкуренцию и кооперацию между работниками, на формирование корпоративной культуры?

На основании изученных теоретических и практических источников можно сформулировать некоторые гипотезы. Мы предполагаем, что в результате внедрения системы геймификации в целом про-

3 Данные предоставлены компанией-разработчиком геймифицированных продуктов GameTrek. URL: http://gametrek.ru/ clients (последнее обращение: 24 марта 2015 г.).

4 Данные предоставлены компанией-разработчиком геймифицированных продуктов Пряники.com. URL: http://www. pryaniky.com/ru/About/Portfolio (последнее обращение: 24 марта 2015 г.). 
исходит усиление управленческого контроля над работниками, в том числе через алгоритмизацию и мониторинг деятельности работников в рамках электронной системы. При этом в процессе внедрения новой системы контроля со стороны рабочих возникают практики активного и пассивного сопротивления. Также происходит усиление конкуренции между сотрудниками, что увеличивает риск ухудшения социального климата в коллективе. Однако положительным моментом является то, что использование дополнительных виртуальных поощрений в ходе игры способствует повышению приверженности организации среди работников.

В теоретической части работы, в первом разделе, рассмотрены классические теории трудового контроля и управления на предприятии. Во втором разделе изучено позиционирование геймификации как современного метода управления в сфере трудовых отношений. В эмпирической части работы описан случай использования геймификации в одном из крупнейших алкогольных холдингов России, который внедрил в свою систему управления трудовым процессом корпоративную социальную сеть «Город», построенную по принципу геймификации.

\section{Автономия и контроль в информационной экономике}

С экономико-социологической точки зрения трудовые отношения - это воспроизводство сложного трудового компромисса, где руководство и работники знают общие правила трудового поведения и правила контроля и пытаются удержать себя и оппонента в рамках этих правил [Радаев 2005: 292].

В начале XX века управленческие инновации Ф. Тейлора и Г. Форда существенно увеличили контроль над трудовым процессом благодаря организации массового производства, основанного на детальной специализации трудовых операций, их механизации, на автоматической доставке работы непосредственно к рабочему и соответственно на принудительном ритме труда [Радаев 2005: 295]. Критическому осмыслению эволюции управленческих практик при капитализме уделяется значительное внимание в работах неомарксистов. Так, Г. Браверман утверждал, что специализация труда облегчает контроль менеджеров за работой, так как легче контролировать рабочего, выполняющего определённую задачу, чем сотрудника, применяющего в трудовом процессе широкий спектр навыков [Braverman 1974]. Р. Эдвардс отмечал, что в XIX веке использовался прямой способ контроля над рабочими: менеджеры осуществляли управление лично. Затем происходит переход к безличным и технически оснащённым механизмам контроля, когда рабочими управляют сами технологии, которые они используют [Edwards 1979]. Например, этот принцип может осуществляться с помощью компьютера, который способен вести тщательный учёт выполненных рабочим операций. В целом с точки зрения критических теорий, выдержанных в русле неомарксизма, автоматизация и компьютеризация производства, появление мобильной связи и Интернета дают дополнительные возможности для усиления управленческого контроля, знаменуя собой становление неофордизма [Шевчук 2002].

В то же время на заре информационного общества многие учёные предполагали, что активное развитие компьютерных технологий в будущем приведёт к появлению инновационных форм занятости и к повышению трудовой автономии [Иноземцев 1998: 114-115]. Согласно теории Р. Инглхарта и К. Вельцеля, поколения, выросшие в условиях относительной материальной обеспеченности, придают большее значение ценностям самовыражения; таким образом проявляется отход от сугубо экономической мотивации человеческой деятельности [Инглхарт, Вельцель 2011]. Современный работник ориентирован на интересную, творческую деятельность, общение с интересными людьми и расширение своего жизненного опыта. Более того, современный работник испытывает потребность быть частью компании и идентифицировать себя с ней [Иноземцев 1997: 18-19]. Изменение личности работника ставит

5 Название организации скрыто с целью сохранения конфиденциальности; название корпоративной социальной сети также изменено. 
перед фирмами задачу отхода от жёстких управленческих схем в духе Ф. Тейлора и Г. Форда. «Новая философия управления», основанная на гуманизации и демократизации труда, подразумевает приспособление техники к работнику, идентификацию работника со своим трудом и включение в трудовой процесс элементов творчества, придающих ему разнообразие.

В целом трудно отрицать, что возможности самовыражения на рабочем месте повысились и информационно-коммуникационные технологии способствуют развитию разнообразных форм трудовой автономии, например, за счёт развития телеработы и электронных рынков. Однако сегодня мы также можем наблюдать, как бизнес использует информационно-коммуникационные технологии для создания и закрепления форм сильной зависимости работника [Шевчук 2010: 44]. Современные технологии позволяют сделать процесс контроля над трудовым процессом тотальным [Lyon 2003: 7]. В частности, развивается практика электронного мониторинга и надзора за деятельностью сотрудников (electronic surveillance) (см., например: [Aiello, Kolb 1995; Sewell 1998: 401; Weckert 2004; Zweig, Webster, Scott 2008]). Электронный контроль над трудовым процессом осуществляется через постоянное видео- и аудиофиксирование деятельности работников, которое ведётся непрерывно, при этом проверка записей и отслеживание поведения конкретного сотрудника могут проводиться выборочно, в любое время. Работники знают, что за ними наблюдают, но не могут видеть наблюдателя, как в концепции «паноптикона» М. Фуко, где был описан аналогичный принцип контроля над заключёнными [Foucault 1977]. Актуальным примером тотального электронного контроля являются современные колл-центры, где с помощью информационных технологий задаются алгоритмы работы, осуществляются мониторинг деятельности и её последующая оценка [Taylor, Bain 1999].

В популярной и управленческой литературе геймификация позиционируется прежде всего как способ улучшения условий труда сотрудников организаций [Зикерманн, Линдер 2014]. В теории этот механизм направлен на мотивацию трудовой деятельности внедрением «креативного» и «развлекательного» элемента игры в работу, то есть на потенциальную возможность самореализации сотрудников при достижении успехов в игре. Однако подход, выдержанный в русле традиций индустриальной социологии, подсказывает, что с социологической точки зрения геймификация может быть направлена в первую очередь на усиление контроля над трудовым процессом за счёт автоматизации рабочих операций, то есть, наоборот, на ограничение трудовой автономии работников. Всё это маскируется «креативным элементом игры», который способствует «быстрому и весёлому обучению» [Зикерманн, Линдер 2014: 135-146], где игра, в свою очередь, на первый взгляд является средством мотивации работников.

\section{Геймификация: фрункционирование механизма в контексте трудового процесса}

Итак, ранее было определено, что ключевыми элементами управления трудовым процессом являются трудовой контроль и мотивация труда. Они, в свою очередь, непосредственно связаны с феноменом геймификации, который позиционируется прежде всего как способ мотивации и предположительно представляет собой инструмент контроля над трудовым процессом. Определим поэтому принцип функционирования данного механизма и установим его основные элементы.

Согласно Г. Зикерманну и Д. Линдер, являющимися одними из ведущих мировых экспертов в области разработки стратегий взаимодействия с сотрудниками и клиентами организаций, «классические способы вовлечения в современном мире больше не работают, если учесть огромное количество отвлекающих факторов, которое стремительно увеличивается, и тот факт, что реальная жизнь всё больше и больше становится похожей на игру. То, что интересует и держит внимание сегодня, завтра может оказаться скучным, и это произойдёт раньше, чем станет понятно, чем можно удержать внимание в будущем» [Зикерманн, Линдер 2014: 23]. Это утверждение говорит о том, что в сфере управления трудовым процессом постоянно требуются новые актуальные методы контроля и вовлечения работни- 
ков. В связи с популярностью онлайн-игр появление геймификации в данной сфере неслучайно, и она вполне может быть признана новой и в свете сегодняшнего дня эффективной тенденцией вовлечения людей в трудовой процесс.

В первую очередь стоит определить, что в настоящее время означает данный термин. Воспользуемся следующим определением: геймификация - механизм, подразумевающий внедрение игровых механик для повышения мотивации людей в улучшении их показателей в любом роде деятельности, что приводит к усовершенствованию функционирования общего процесса. При этом игровые механики это наборы правил, заимствованных из социальных онлайн-игр и предназначенных для поощрения и стимулирования [Цыплакова 2013: 54].

Такое определение даёт более или менее ясное представление о геймификации, тем не менее действие данного механизма и его влияние на трудовое поведение работников остаются нераскрытыми, поэтому в данной работе мы постараемся ликвидировать этот пробел. При этом важно обозначить следующее: несмотря на то что феномен геймификации связан с социологией и психологией, все существующие по этой теме источники сводимы к специализированной технической литературе для разработчиков геймифицированных систем и к менеджериальной литературе для управленцев. Необходимая для понимания функционирования механизма геймификации литература, включённая в обзор, предложенный далее, имеет поэтому преимущественно прикладной характер.

Для данной работы интерес представляют научные статьи, посвящённые технической стороне функционирования механизма геймификации с описанием возможных игровых механик и их комбинаций, а также научные статьи по теории и практике внедрения геймификации в бизнес - как в маркетинге (чаще), так и в сфере управления персоналом (реже). Статьи для анализа отобраны исходя из их релевантности теме, наибольшего индекса цитирования и опубликованные не позднее 2010 г. Акцент при этом сделан на следующие параметры:

- возможные варианты игровых механик и их комбинаций с изучением потенциального влияния на поведение людей в заданной ситуации;

- успешные случаи внедрения в бизнес как в сфере привлечения потребителей, так и в сфере управления персоналом.

Рассматривая ситуацию, когда геймификация используется в качестве инструмента контроля над работниками и повышения их мотивации, следует понимать, что такие социальные инструменты, как игровые механики, предназначаются для введения инноваций в социальных и корпоративных взаимоотношениях, поддержание которых повышает лояльность работников и помогает им чувствовать себя особенными [Deterding et al. 2011b]. Деятельность по работе с сотрудниками должна быть правильно структурирована. Компаниям необходимо иметь классификацию сотрудников, в которых они нуждаются, но не с точки зрения их деловых качеств, а заостряющую внимание на социальных обязательствах. Поскольку люди отличаются друг от друга особенностями характера, привычками и способами восприятия информации из социальных СМИ, компании должны понимать, как наиболее эффективно вовлечь сотрудников в трудовой процесс [Frang, Mellstrand 2011].

Игровые механики в данном случае лишь отдалённо связаны с игрой в классическом понимании этого слова, тем не менее оно неоднократно будет использовано в этой работе. Аналогично и выражение «правила игры» имеет значение, более соответствующее «правилам организации процесса». К таковым, например, относятся правила, организующие распределение и использование ресурсов, или правила, управляющие действиями так называемых игроков. Ключевым здесь является то, что эти пра- 
вила универсальны, то есть они будут одними и теми же для всех участников процесса независимо от их личностных особенностей. И игра будет одной и той же, и результаты, соответственно, тоже. Правила игры с целью надёжности результата должны быть правильно скомбинированы и располагаться в грамотной последовательности, что и представляет собой эффективный принцип игровой механики [Deterding et al. 2011a]

\section{Основные элементы понятия «геймификация»}

Определим набор ключевых элементов концепта «геймификация» в контексте кейса компании, производящей алкогольные напитки. Отметим, что перечисленные ниже элементы геймификации характерны для данного кейса и являются универсальными для «классической» геймификации.

\section{1. Игровые механики}

Данный индикатор подразумевает наличие игровых механик. В каждом конкретном кейсе эти наборы могут быть различными. В качестве показателей обозначим возможные варианты игровых механик этого индикатора, влияние которых на мотивацию можно выявить в ответах работников на соответствующие вопросы, например:

- достижения: виртуальное или материальное (но не денежное) выражение результата выполнения действия (медаль, уровень, вознаграждение, очки). Игрок может расценивать в качестве награды вещь, признаки индивидуальности и социального положения, символ членства;

- глобальное значение: мотивацию игроков в высшей степени увеличивает вера в участии создания чего-то великого, впечатляющего, намного более важного, чем они сами. Эта механика также может быть направлена на сплочение коллектива в целом;

- рейтинги персональные и групповые. Персональные рейтинги публикуются для того, чтобы каждый сотрудник мог видеть свой текущий уровень развития, а групповые - чтобы сотрудники могли оценить уровни развития коллег. Это также повышает мотивацию и усиливает стремление к улучшению собственных результатов.

\section{2. Вовлечённость}

В данном случае под вовлечённостью подразумевается заинтересованность работника в происходящем (как в игре, так и в работе). Этот индикатор может быть измерен таким показателем, как степень участия в игре (сильная или слабая).

\section{3. Конкурентная борьба}

Конкурентную борьбу можно измерить следующими показателями: степень конкуренции (слабая, средняя или жёсткая); отношение к системе рейтингования (отрицательное или положительное); портрет победителя (качества, которыми должен обладать победитель игры, по мнению самих победителей и по мнению проигравших); возможные препятствия для победы; конфликтные ситуации, вызванные конкуренцией в коллективе.

\section{4. Система поощрения}

Система поощрения также может быть разделена на два показателя: (1) поощрения в игре и (2) реальные поощрения в работе, которые предположительно будут связаны между собой. Например, накопленные баллы в игре конвертируются в реальные призы - корпоративные сувениры. 


\section{5. Правила иеры}

Показателями этого индикатора могут быть следующие: характер правил (жёстко регламентированные правила, которые нельзя изменять или нарушать, и (или) периодически изменяющиеся правила по ходу игры) и санкции за нарушения правил.

\section{6. Результат}

Данный индикатор можно охарактеризовать тремя показателями: (1) удовлетворение от игры; (2) улучшение или ухудшение отношений в коллективе; (3) реальные успехи в работе (например, продвижение по службе, повышение зарплаты). Эффект от внедрения геймификации будет измерен наличием удовлетворённости от игры у работников, на которых оказано воздействие, и оценкой эффективности механизма геймификации управляющими сотрудниками. Предполагается, что механизм эффективен для мотивации работников при условии воздействия вышеперечисленных индикаторов на рабочее поведение сотрудников компании. Однако мы будем анализировать влияние геймификации на трудовые отношения не с точки зрения его эффективности, а с точки зрения качества этого влияния.

Основными составляющими геймификации являются:

- специализированное программное обеспечение с набором механик, на которых базируется игра;

— конкурентная борьба между участниками игры;

- виртуальная система поощрения.

На основе изученных примеров внедрения геймификации условно можно выделить классический и упрощённый типы.

Под упрощённым типом геймификации подразумевается тот, при котором участие в игре не является обязательным. Например, такой тип геймификации присутствует в компании «T-Systems CIS Pоссия». В этой компании есть корпоративное приложение, в котором сотрудники могут общаться между собой, а также выполнять различные задания, связанные не с их непосредственной работой, но с историей и продукцией компании. Выполнение этих заданий не обязательно, а добровольно, однако стимулируется возможностью получения специальной виртуальной валюты - «мегабайтов», которую можно обменять на покупку сувениров во внутреннем магазине компании «T-Store». Важно, что данный тип геймификации предполагает соревнование между сотрудниками: тот, кто наберёт больше баллов, получит и больше сувениров. Однако этот тип геймификации не предполагает ведения рейтингов. Накопление виртуальных баллов происходит исключительно для обмена на сувениры, при этом баллы не возбраняется «дарить» коллегам, то есть с помощью этой валюты руководители и сотрудники могут благодарить друг друга. Это говорит о том, что геймификация в данном случае не обостряет конкурентную борьбу между сотрудниками.

В свою очередь, классический тип геймификации представлен, например, в компании «АВВYY», занимающейся разработкой решений в области распознавания текстов и лингвистики. В «АВВYY» внедрили в свою корпоративную сеть для общения интересное дополнение, позволяющее сотрудникам пройти виртуальные квест-туры по компании, выполняя задания, за которые начисляются виртуальные баллы. Это стимулирует работоспособность, создавая искусственную конкуренцию. Игрокам, правильно отвечающим на вопрос, дополнительно присваивается определённый уровень мастерства. Участие в квест-турах обязательно, и на основании результатов квестов формируются рейтинги сотрудников, которые публикуются там же, в игре. 
С социологической точки зрения наибольший интерес представляет классический тип геймификации, который в данной работе будет описан на примере компании-производителя алкогольной продукции, где он хорошо представлен. Таким образом, на основе вышесказанного в следующем разделе подробно будет описана методология исследования.

\section{Методология исследования}

\section{Основные элементы методологии}

Исследование выполнено методом кейс-стади на основе материалов, которые получены во время работы автора статьи в российской компании, производящей алкогольные напитки.

Использование метода кейс-стади обосновано следующим: (1) инновационность и, следовательно, ограниченная распространённость данной управленческой практики в российских компаниях; (2) пилотный характер исследования ввиду недостаточной разработанности данной проблематики в социологической литературе (среди немногих социологических работ о геймификации отметим: [Jacobs 2013; Mollick, Rothbard 2014]); (3) трудность доступа к респондентам и закрытость информации о системах геймификации для аутсайдеров. Источником информации станут интервью с менеджерами и работниками изучаемой компании. Надеемся, что результаты нашего исследования внесут вклад в изучение геймификации как нового механизма мотивации труда и контроля над трудовым процессом.

Выбор компании в качестве объекта исследования обусловлен в первую очередь тем, что это одно из немногих российских предприятий, использующих геймификацию для контроля над трудовым процессом. Кроме того, данная компания являлась местом работы автора, что облегчало доступ к полю и предоставило возможность изучить процесс изнутри. При этом разделение объекта исследования на две части обусловлено предположением о том, что под влиянием определённой геймифицированной системы контроля над трудовыми отношениями у руководства компании и работников могут быть различные стратегии поведения в процессе труда, провоцирующие конфликтные ситуации и соответственно разные стратегии решения возникающих проблем.

\section{Методы сбора и анализа данных}

В качестве данных для решения практических задач исследования использованы 16 полуформализованных интервью с сотрудниками компании, производящей алкогольные напитки, где применяется геймификация в сфере контроля над трудовым процессом и мотивации труда. Средняя продолжительность интервью - 45 мин, средний объём транскрипта интервью - 35 тыс. знаков (с пробелами).

Для изучения механизма действия геймификации как основы управления работниками и выявления её составных элементов взяты интервью с управляющим персоналом — сотрудниками, разрабатывающими и внедряющими геймифицированный механизм мотивации работников.

Для выявления того, каким образом вовлечение работников в геймифицированный трудовой процесс влияет на их отношение к выполнению профессиональных обязанностей, проведены интервью с сотрудниками, непосредственно участвующими в игре, то есть вовлечёнными в геймифицированный рабочий процесс и выполняющими задания через приложение. На основе полученных данных сделан анализ удовлетворённости работников новыми условиями труда. Изучение сопутствующих вопросов основывается на полученных в ходе интервью с обеими категориями сотрудников компании данных. В результате их анализа рассмотрены, во-первых, практики активного и пассивного сопротивления работников, трудовые конфликты и достигаемые компромиссы; во-вторых, воздействие геймификации 
на социальные отношения внутри коллектива, то есть изучены особенности конкуренции и кооперации между работниками, а также и формирование корпоративной культуры.

\section{Информационная база}

Основным источником данных являются полуформализованные интервью с сотрудниками отдела «Общий и торговый маркетинг» компании, производящей алкогольные напитки. В исследовании использована квотная выборка. Предпочтение этому типу совокупности отдано в первую очередь из-за внутреннего устройства компании. Корпоративная сеть «Город», являющаяся интерактивной платформой для геймифицированной коммуникации между сотрудниками организации, используется в головном офисе отдела «Общий и торговый маркетинг», который находится в Санкт-Петербурге. Важно обозначить, что, как и в любом отделе, сотрудники занимают различные должностные позиции, поэтому первое деление генеральной совокупности объекта исследования - всех сотрудников отдела «Общий и торговый маркетинг» в Санкт-Петербурге, имеющих отношение к геймификации, — происходит по принципу иерархичности. Однако для нас значима не столько внутренняя сложная иерархия в отделе, сколько то, что изначально не все сотрудники отдела вовлечены в игровой процесс. Активными участниками являются только те сотрудники, которые отвечают за сбыт продукции в торговых точках: региональный руководитель, территориальные руководители, ассистенты территориальных руководителей и торговые представители. В данном случае именно торговые представители организации участвуют в игре и выполняют её задания. Соответственно, нас интересует только эта часть сотрудников отдела 48 чел. Применительно к нашей проблеме интересующие нас сотрудники условно разделены на две категории: (1) «руководство», то есть те, кто разрабатывает систему геймификации, внедряет её и оценивает результаты; (2) «работники», то есть те, кто выполняет геймифицированные задания. По данным компании, эти две категории сотрудников в рамках отдела делятся в следующем соотношении: $25 \%$ (региональный менеджер по Санкт-Петербургу и Ленинградской области, территориальные менеджеры, ассистенты территориальных менеджеров - 12 чел.) и 75\% (торговые представители - 36 чел.) от общего числа участников игры. При этом выбор информантов в каждой группе будет происходить случайным образом, при помощи генератора случайных чисел, путём присвоения всем сотрудникам порядковых номеров (гендерный критерий учтён не будет).

Используемое количество интервью - 16 бесед (четыре с «руководством» и 12 с «работниками»). Ограничения исследовательского поля в данном случае связаны с небольшим размером выборки. Однако предполагается, что для изучения геймификации методом кейс-стади и с учётом редкого использования подобных инновационных механизмов в сфере управления персоналом в России эти ограничения естественны. Вспомогательным источником являются данные о геймификации, полученные при анализе внутренних документов компании.

Анализ данных интервью проводился при помощи программного обеспечения NVivo с применением методов открытого, осевого и выборочного кодирования по фокусам интервью [Страусс, Корбин 2001].

\section{Процесс игры в организации: мотивация труда и контроль над трудовым процессом}

На первом и втором этапах осевого кодирования 11 интервью из 16 мы получаем схему, представленную на рисунке 1, которая характеризует геймификацию в данной компании. Основными подкатегориями являются «контроль над трудовым процессом», «мотивация труда» и «корпоративная культура». В дальнейшем основное внимание будет уделено анализу данных, касающихся первых двух подкатегорий. 


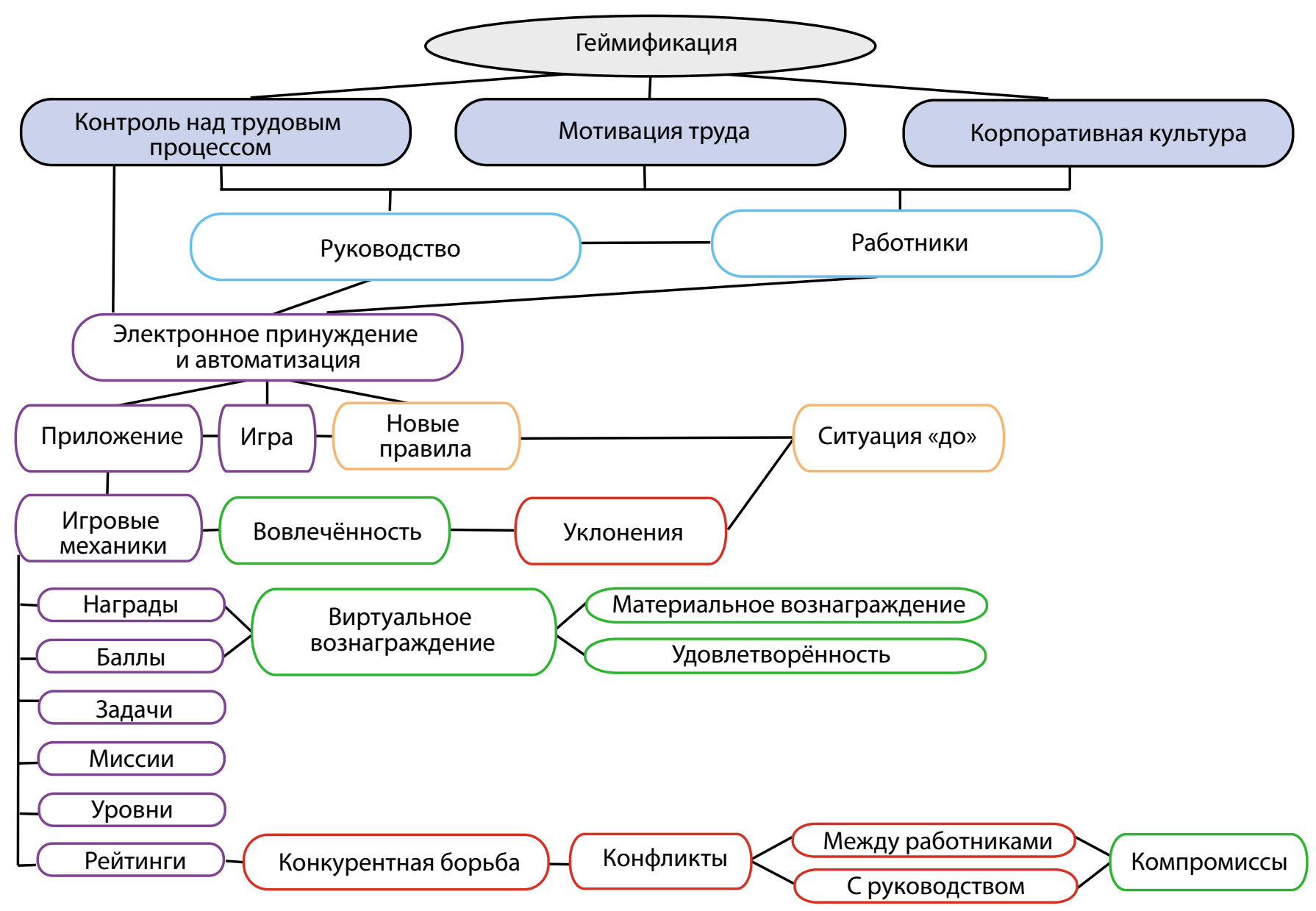

Рис. 1. Схема осевого кодирования, часть 1 (11 интервью)

В данном случае мы анализируем пример внедрения геймификации в изучаемой компании. Между определёнными сотрудниками (торговыми представителями компании) существует соревнование в достижении наибольших успехов в работе, что, в свою очередь, поощряется определённой структурой начисления виртуальных баллов и обмена их на награды.

С точки зрения геймификации трудового процесса в обязанности такого сотрудника входит фиксирование своей трудовой деятельности в специальном корпоративном приложении «Город», установленном на личном карманном портативном устройстве (КПУ). При этом все рабочие задания и распоряжения начальства для торговых представителей (ТП) размещаются только в этой корпоративной сети, и получить их можно только в «личном кабинете» с помощью личного КПУ или компьютера с установленным приложением «Город». Этот момент важен для нас, поскольку здесь учтено одно из обязательных правил геймификации любого процесса - использование специализированного программного обеспечения. Таким образом, перед нами классический пример геймификации трудового процесса. Не останавливаясь подробно на описании деятельности работников, отметим, что их действия в каждой торговой точке (ТT) в рамках такой пошаговой системы заключаются в следующем:

— вход в систему «Город»; выбор соответствующей ТТ на маршруте; фиксирование начала работы в данной TT с помощью включения GPS, определения местоположения и размещения в системе фотографии фасада здания ТТ; 
— выполнение работы по мерчандайзингу продукции и подробное заполнение отчёта (по шаблону) по проведённой работе в соответствии с прописанными в системе «заданиями», касающимися каждой отдельной ТТ;

- заполнение опросных листов, касающихся новых заказов от ТТ на соответствующие наименования товаров; формирование заказа в шаблонной форме, которая автоматически синхронизируется с общей базой заказов для склада;

— оформление отчёта о текущих акциях, которые были предложены данной ТТ и одобрены руководством ТТ; приложение официальных документов о формальном согласии владельцев ТТ на участие в акции с контактами и подписями.

\section{Задачи игроков}

В компании геймифицирована такая повседневная задача для любого ТП, как посещение максимального количества различных торговых точек за определённый промежуток времени. За каждое посещение начисляются виртуальные баллы, которые, в свою очередь, конвертируются в виртуальные награды и значки, видимые и другим сотрудникам в системе (в «Городе» выполненные задания любого ТП видны не только руководителям, но и другим ТП).

\section{Миссии игроков}

Различные ограниченные по времени задачи являются «миссиями», которые сотрудник изначально получает сформулированными в игровых терминах: «подключи к акции “снижение цены на продукт $N$ ” 10 TТ за два дня» (допускаются формулировки с фиксированным количеством ТТ). Также к миссиям причисляются маршруты, которые торговые представители должны проходить в рамках установленного времени.

\section{Достижения игроков}

Достижения - это баллы, уровни и награды, которые фиксируются в личном кабинете каждого работника (см. рис. 2).
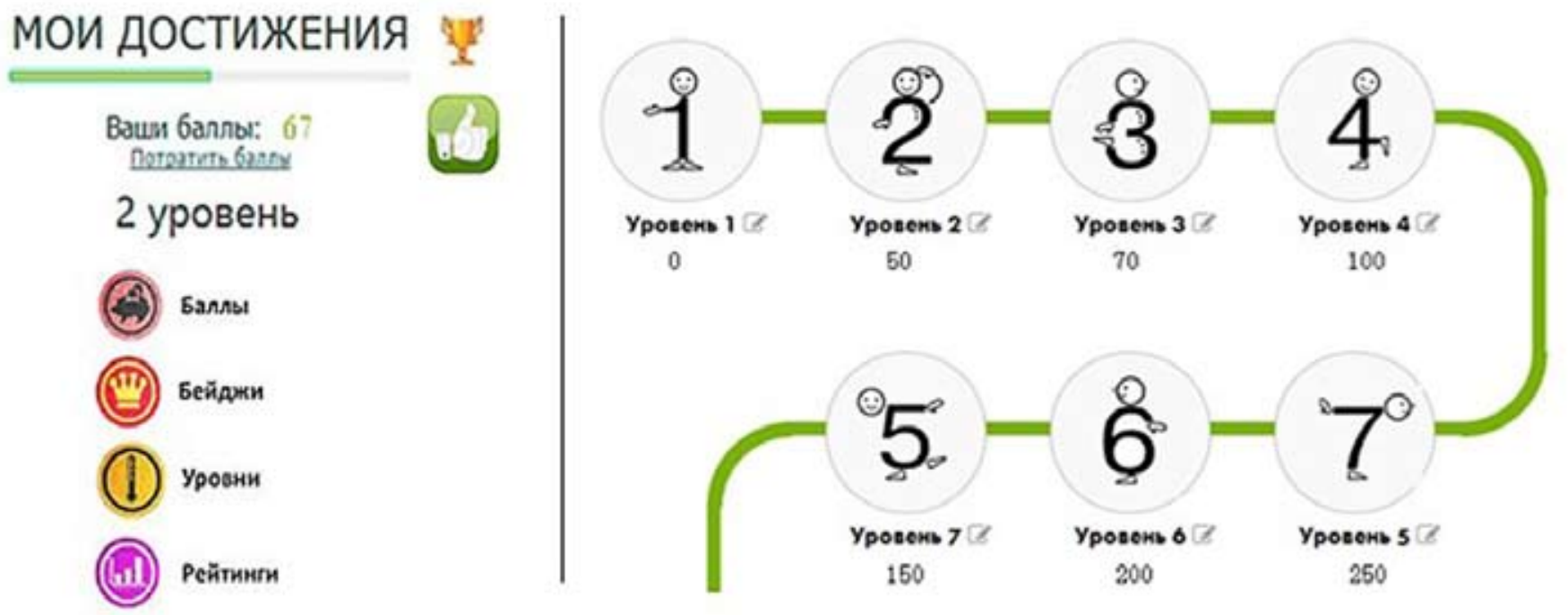

Рис. 2. Пример личного кабинета участника игры. Система учёта баллов и перехода по уровням в системе 


\section{Достижения игроков: уровни}

Установлены чёткие правила перехода по уровням. Он происходит при накоплении определённого количества баллов. При отсутствии общей легенды ${ }^{6}$ существует простая дифференциация уровней: 1-й, 2-й, 3-й, .., n-й.

\section{Достижения игроков: баллы и бейджи}

За выполнение заданий сотрудникам начисляются виртуальные баллы из расчёта один балл за одну подключённую ТТ к любой акции. При наличии приоритетных акций за подключение ТТ к ним зачисляется по два балла. За успешное прохождение миссии начисляются три балла. Примечательно, что данный случай не совсем типичный, так как зачастую в качестве вознаграждения в различных компаниях используются собственные внутренние валюты (например, «ачивки» в Яндексе). В изучаемой компании виртуальное вознаграждение начисляется исключительно баллами, которые можно обменять на разные виды наград. Например, информанты рассказывали о том, что получали в подарок наборы из трёх сувенирных миниатюрных бутылок водки «N»; они хранят этот подарок, поскольку это «эксклюзивная вещь, которую просто так в магазине не купишь» (информант № 2, женщина, работник, торговый представитель). Такая тактика объясняется локальным руководством как «корпоративная уловка, позволяющая сэкономить на премиях» (информант № 6, мужчина, руководство, территориальный менеджер), ведь на самом деле номинал подарочного сертификата и его реальная стоимость могут различаться.

\section{Достижения игроков: награды}

Накопленные баллы конвертируются в награды, в качестве которых обычно используются «вещественнble nризы» (информант № 1, женщина, работник, торговый представитель), материально подтверждающие достижения сотрудников. Такие призы нельзя обменять на реальные деньги. Накопленные баллы могут «списываться» со счёта в обмен на небольшие призы (брендированные сувениры с символикой компании, сувенирная продукция, сертификаты в магазины-партнёры на виртуальные суммы). Также есть некоторые «несгораемые суммы», когда все сотрудники по достижении 50 баллов получают гарантированные призы. Это сделано для «стимулирования торговых представителей не тратить сразу все балль, а копить их, выполнять больше заданий и получать большие призы» (информант № 3 , мужчина, руководство, территориальный менеджер). Вероятно, мотивирование работников построено на теории ожидания В. Врума, согласно которой мотивация работника будет ослабевать, если ценность получаемого за труд вознаграждения будет для него невелика [Врум 1964]. В нашем случае ожидание получить большое и ценное вознаграждение может мотивировать работника выполнять больше заданий, чем он выполнял бы, обменяв баллы на небольшие призы.

В целом важно понимать, что получение внешнего вознаграждения, пусть и виртуального или материально выраженного в получаемых призах, непосредственно связано с внутренним вознаграждением, то есть с удовлетворённостью результатами труда и гордостью за профессиональные заслуги.

6 В классическом варианте геймификации для потребителей часто существует общая легенда, по которой потребитель в специальном приложении играет определённую роль - например, принц спасает принцессу от дракона, выполняя различные задания по ходу игры, где в качестве заданий нужно отвечать на вопросы о продукции конкретной компании. 


\section{Рейтинаи игроков}

И наконец, самое важное - составление рейтингов ${ }^{7}$ на основе накопленных сотрудниками баллов. Такие рейтинги позволяют в конце месяца определить трёх победителей, которые получают уже большие призы. В описываемой игре существуют персональные и групповые рейтинги; персональные публикуются для того, чтобы каждый сотрудник мог видеть свой текущий результат, а групповые — чтобы сотрудники могли оценить результаты коллег, что также способствует повышению мотивации и стремлению улучшить свои результаты ${ }^{8}$. Успехи работников публичны, то есть и количество накопленных баллов, и все рейтинги располагаются в общем доступе таким образом, что каждый работник может видеть результаты другого. Подобный механизм говорит о наличии двойного надзора: деятельность работников контролируется, во-первых, со стороны руководства и, во-вторых, через самоконтроль общедоступная публикация результатов стимулирует работника к их улучшению.

Таким образом, проанализировав вышеописанный процесс, стоит в первую очередь отметить интересный механизм контроля над трудовым процессом, созданный автоматизацией рабочих операций: все действия работника изначально запрограммированы в системе, при этом их выполнение обязательно в строгом линейном порядке, описанном в инструкции и во всплывающих в процессе работы подсказках. И, что самое важное, выполнение каждого действия (например, перестановка продукции на полке) обязательно должно фиксироваться в системе. С точки зрения руководства компании, подобный принцип регулирования деятельности рабочих является способом трудового контроля, построенного на автоматизации и установлении жёсткой структуры рабочих операций. Возникает вопрос: зачем нужен такой жёсткий способ контроля? Вероятно, необходимость в постоянных отчётах работников и фиксирование всех их действий спровоцированы потерей доверия к работникам.

Говоря о стратегии мотивации труда с помощью геймификации трудового процесса, можно сделать промежуточный вывод о том, что в основе геймификации лежит комплексная мотивационная теория Л. Портера и Э. Лоулера [Porter, Lawler 1968]. Ключевыми элементами в данном случае являются ожидание вознаграждения, полученного за результативный труд, и осознание работником своего места в компании. При этом положительные результаты работы приносят её исполнителю чувство удовлетворённости, которое, в свою очередь, обусловлено внутренним и внешним вознаграждением и его справедливостью. Внутренним вознаграждением является удовлетворение результатами труда и гордость за свои профессиональные заслуги, внешним вознаграждением - поощрения, премии и повышение уровня заработной платы.

Что касается деятельности менеджеров, контролирующих данный процесс, важно отметить, что в их обязанности входит проверка работы торговых представителей, которая происходит также в приложении «Город». Из интервью с представителями руководства отдела следует, что геймифицированная система на самом деле была изначально внедрена для того, чтобы улучшить контроль над деятельностью торговых представителей и стимулировать их производительность труда. В данном случае все опрошенные менеджеры также подчёркивали, что отслеживать выполнение работы подчинённых стало намного проще, поскольку вся отчётность автоматически появляется в общей базе, её можно проверить в любой момент при наличии доступа к системе. Однако интересно и то, что менеджеры, хотя не являются активными участниками игры, в ней всё равно заняты, не только потому, что проверяют работу торговых представителей, но и потому, что их обязанности тоже чётко регламентированы, и их выполнение жёстко контролируется. Понятно, что в этой организации высшим контролирующим

7 Скриншот реального рейтинга приведён быть не может из соображений сохранения конфиденциальности личных данных сотрудников.

8 По официальной версии, высказываемой руководством отдела, курирующего процесс игры. 
органом является руководство компании. Однако в данном случае работа отдела сбыта продукции базируется на максимальной автоматизации всех рабочих процессов и переносе большой части операций в систему «Город», поэтому не будет ошибкой допущение, что деятельность этого отдела контролируется с помощью геймификации. Соответственно, подходит аналогия с принципом трудового контроля по Форду, который описывает конвейерное производство, основанное на детальной специализации трудовых операций, механизации этих операций, автоматической доставке работы непосредственно к рабочему и принудительном ритме работы [Радаев 2005: 273]. Только в нашем случае вместо конвейеров используется специализированное программное обеспечение, которое позволяет осуществить автоматизацию трудового процесса. Таким образом мы наблюдаем тот же тейлоризм, но адаптированный под потребности информационного общества. Принцип действия геймификации, как и в концепции тейлоризма, предполагает оптимизацию трудового процесса и устранение неэффективных факторов в производственной системе путём создания строго определённого алгоритма последовательных простых операций, что, в конце концов, должно привести к максимальной производительности.

Итак, определено, что явная цель внедрения геймификации в трудовой процесс - максимизация производительности труда. Можно предположить, что игра, лежащая в основе геймификации, является средством мотивации работников, однако оказалось, что это только частично верно. Несмотря на то что геймификация позиционируется как «креативныий способ мотивации труда» (информант № 10 , мужчина, работник, торговый представитель), превращающий работу в соревнование (наличие призовых мест, подарков), в действительности это способ влияния на рабочее поведение сотрудников компании. В этом контексте возникает предположение: может быть, геймификация — лишь «приманка», способ принуждения работников к перевыполнению плана, завуалированный развлечением? При этом процесс позиционируется таким образом, будто мысль об увеличении объёма выполняемой работы возникает у самих работников, желающих получить вознаграждение, которое, как мы уже показали, даже не выражено в реальных деньгах. Получается, что в контексте трудовых отношений геймификация лишь с первого взгляда выглядит как способ мотивации труда, а на самом деле является методом управления трудовым процессом в целом.

Итак, геймификация (или модифицированный научный менеджмент) направлена на следующее:

- рационализация трудового процесса через стандартизацию рабочих процедур и введение строго определённых алгоритмов;

- вовлечение работников в игру, а затем стирание грани между игрой и работой и вовлечение работников в работу;

- принуждение к игре (работе) для получения данных о рабочей деятельности сотрудников компании и об их стратегиях поведения в различных ситуациях в виртуальном взаимодействии, что в итоге используется для повышения производительности труда.

Говоря о социальном эффекте, можно подвести промежуточный итог: действительно, в своём классическом варианте, который мы наблюдаем на примере изучаемой компании, геймификация является инструментом контроля над трудовым процессом.

\section{Электронный контроль над трудовым процессом и электронное принуждение}

В ходе данного исследования было выявлено, что геймификация может быть признана примером осуществления электронного контроля над трудовым процессом, аналогичного действующему в коллцентрах [Taylor, Bain 1999]: игра-работа построена на обязательном и принудительном использовании 
компьютерных технологий. Значит, внедрение компьютерных технологий для автоматизации рабочих операций в работу торговых представителей данной фирмы-производителя алкогольных напитков способствует организации электронного принуждения.

В теории внедрение компьютерного приложения с честно прописанными правилами игры должно способствовать повышению автономии труда за счёт автоматизации действий и создания видимости того, что контроль над деятельностью работников осуществляет не столько руководство, сколько сами работники при помощи компьютерной системы. При этом соревнование и наличие развлекательных элементов призваны содействовать снижению рутинности работы, что для работников должно уменьшить впечатление контроля над их деятельностью и создавать видимость повышения комфорта условий труда. Однако на практике геймификация направлена не на снижение контроля над деятельностью работников, а, наоборот, на его повышение, более того, на создание тотального контроля со стороны как руководства, так и других работников.

\section{Геймификация как инструмент повышения приверженности организации и формирования корпоративной культуры}

На рисунке 3 представлена схема выборочного кодирования всех собранных данных, сочетающая результаты первого осевого кодирования (см. рис. $1-11$ интервью) и второго осевого кодирования (дополнительные пять интервью).

В ходе исследования - после сбора всей необходимой информации и анализа данных — было выявлено, что ключевой категорией можно считать «контроль над трудовым процессом», так как геймификация оказалась направлена именно на это. При этом две ранее равноценные подкатегории «контроль» и «мотивация» в реальности взаимодействуют таким образом, что мотивация труда представляет собой явную цель руководства компании, а контроль над трудовым процессом - латентную, но основную цель, ради которой была использована геймификащия.

На схеме рисунка 3 отображена категория «принудительное развлечение», которая включила ранее обсуждённые «электронное принуждение», игру и «приложение». Были добавлены и такие важные категории, как «социальный климат», «практики сопротивления» и «причастность», суть которых будет раскрыта при последующем анализе.

Итак, продолжим анализ и обратимся к тому, что ещё не было освещено, но обсуждалось информантами во всех интервью.

На основе эмпирических данных ранее было выявлено: введение конкурентной борьбы за поощрение и признание приводит к стремлению прилагать больше усилий для достижения высоких личных результатов в работе и к повышению производительности труда всей компании, а также способствует повышению вовлечённости работников и их идентификации с организацией.

В ходе интервью информанты отмечали, что важным элементом стимулирования трудовой активности в данной организации является возможность получения различных призов в обмен на заработанные баллы. В этом контексте примечательно следующее: вручение призов с корпоративной символикой (брендированные ручки, календари, майки) имеет в целом положительный отклик у сотрудников организации: «В этом году у нас были очень красивые новогодние календари. Жалею, что они быстро закончились, в следуюшем году, наверное, больше куплю и друзьям подарю» (информант № 14, женщина, работник, торговый представитель). Более того, складывается впечатление, что сотрудники данной организации гордятся местом своей работы и хотят всячески это подчеркнуть, приобретая продукцию 


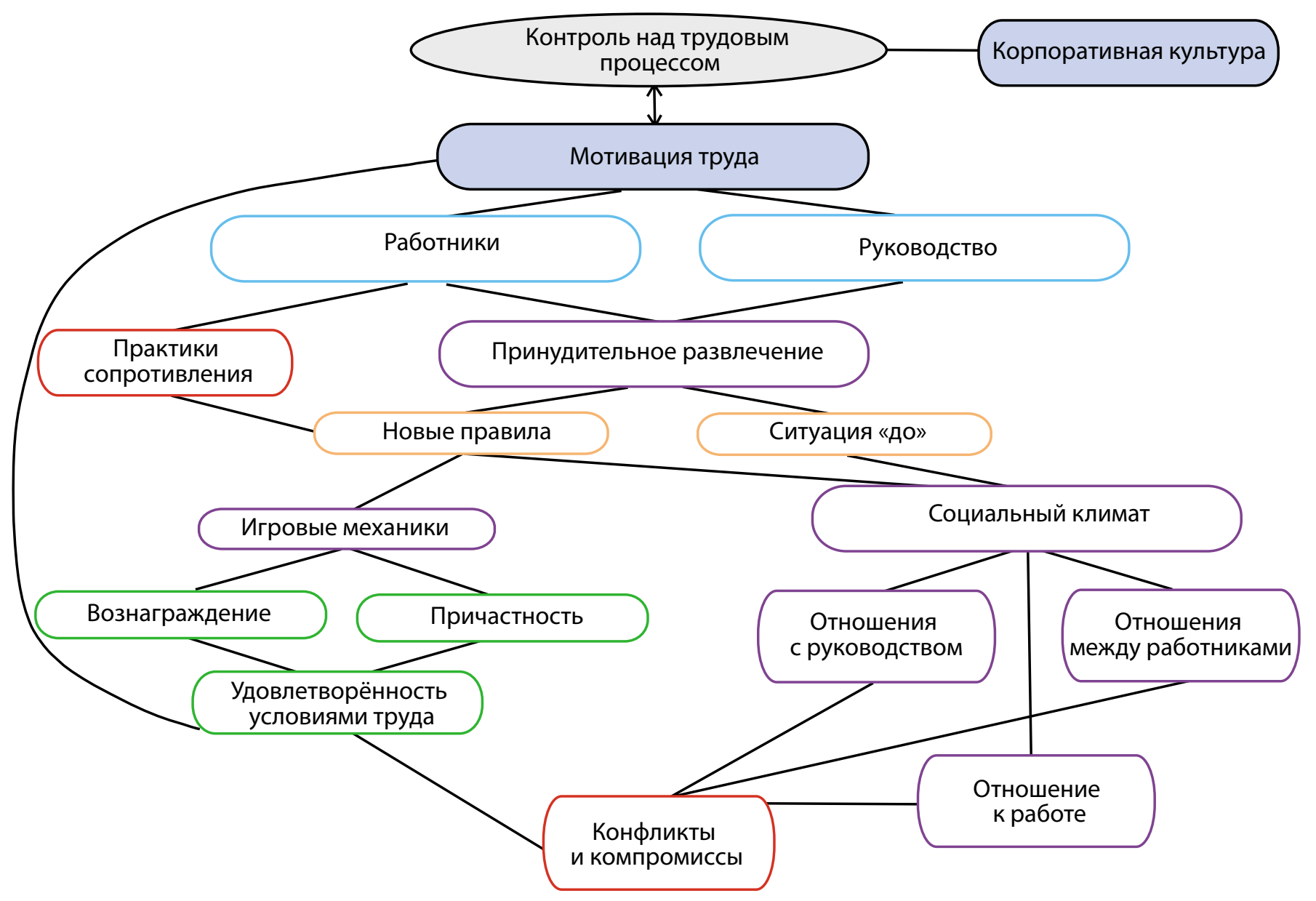

Рис. 3. Схема выборочного кодирования (16 интервью)

с символикой компании. На основании этого можно сделать вывод: обладание брендированной продукцией и сувенирами способствует усилению лояльности к организации.

В данном случае получение в качестве вознаграждения брендированной продукции положительно сказывается на осознании работником себя как части компании. Символика компании на личных вещах, хранящихся и в офисе, и даже дома, позволяет работникам считать профессиональную принадлежность и место работы частью своей идентичности.

Этот факт, в свою очередь, говорит о том, что использование виртуального поощрения (в частности, призов с корпоративной символикой) способствует повышению приверженности организации. При этом важно, что брендированные сувениры, которые можно «купить» в специальном онлайн-магазине только в обмен на виртуальные баллы, имеют среди сотрудников даже больший успех, чем сертификаты в магазины-партнёры, хотя в действительности их реальная стоимость сравнительно ниже. Вероятно, это объясняется тем, что уникальность и труднодоступность призов, приобретаемых только в фирменном магазине компании, повышают их символическую ценность.

Также важно, что общая идеология «работаем, весело играя», лежащая в основе геймификации и пропагандируемая внутри компании, в результате должна формировать определённую корпоративную культуру, которая, в свою очередь, должна поддерживать мотивацию работников и повышать их удовлетворённость условиями труда. И на практике это действительно так: если игра непосредственно вписана в работу и участие в игре является обязательным, то геймификация становится частью корпо- 
ративной культуры, делающей условия труда в данной конкретной компании «уникальными». И руководство компании, и работники утверждают, что внедрение игрового элемента является уникальным решением проблем в организации трудового процесса для торговых представителей в компаниях, специализирующихся на производстве и сбыте продукции.

\section{Влияние игры на работу или принудительное развлечение}

Использование интерактивной и развлекательной деятельности для поддержания корпоративного духа и организации коллективного досуга применяется давно и во многих компаниях (например, корпоративы или совместные походы в боулинг). Так что, по сути, геймификация является аналогом подобных практик и также в теории направлена на улучшение условий труда работников. Соответственно, она должна положительно влиять на отношение к работе в целом за счёт позитивного отношения к игре. Но так ли это на самом деле?

В ходе исследования было обнаружено, что в том случае, когда геймификация непосредственно связана с рабочей деятельностью (как в изучаемой нами компании), она является обязательной9. Иными словами, если сотрудник принимает условия труда, ему надлежит выполнять свою работу, используя соответствующее программное обеспечение (в нашем случае приложение «Город»). В связи с этим интересно узнать, каким образом геймификация была предложена для внедрения в компанию, и как её приняли сотрудники.

По данным интервью, оказалось, что до внедрения геймифицированной системы — в начале 2013 г. в отделе «Общий и торговый маркетинг» было проведено внутреннее исследование, целью которого было изучение личных качеств сотрудников. По результатам это исследования было выявлено, что «большинство сотрудников отдела (65\%) хотят получать удовольствие от работы и требуют постоянной обратной связи и поощрения от руководителя» (информант № 6, мужчина, руководство, территориальный менеджер). Вероятно, это связано с тем, что большинство опрошенных работают преимущественно вне офиса (торговые представители) и при нечастом личном общении с руководством в основном выслушивают выговоры и замечания. Руководством поэтому был предложен выход из сложившегося положения, который в теории должен был решить проблемы и с получением удовольствия от работы, и с поощрениями. Этим выходом стала геймификация.

В этом контексте важны согласие на изменения в устройстве трудового процесса и принятие этих изменений, ведь вся работа торговых представителей компании была встроена в мобильное приложение и практически полностью алгоритмизирована и автоматизирована. Учитывая, что весь процесс также был вписан в игровой контекст, можно сказать, что речь идёт о принудительном развлечении, так как работники не имеют возможности не выполнять хотя бы минимальные рабочие задачи и, значит, обязаны участвовать в игре. В связи с этим возникали различные мнения насчёт изменений в устройстве трудового процесса. Например, есть положительные мнения о новом формате работы: «Стало намного удобнее, чем раньше» (информант № 7, женщина, работник, торговый представитель); «Мне нравится то, что теперь нам дают уже готовый маршрут, нарисованный на карте <...> Раньше просто список торговых точек выдавали на бумажке» (информант № 13, женщина, работник, торговый представитель). Есть достаточно нейтральные: «Я думаю, я не стал больше работать, когда нам внедрили “Город”, я как-то не стремлюсь особенно эту коллекцию значков собрать... Работаю, как работаю» (информант № 8, мужчина, работник, торговый представитель). Есть и отрицательные мнения о влиянии игры на работу: «Не то чтобы я очень рад тому, что каждый шаг нужно фиксировать в этой программе... Она вообще часто глючит и неправильно определяет местоположение, и тогда

9 Подробнее о геймификации как о принудительном развлечении см.: [Mollick, Rothbard 2014]. 
визит в TT не засчитывается» (информант № 5, мужчина, работник, торговый представитель). Или: «Я вообще был бы рад, если бы приложение оставили (оно в общем-то удобное для отчётов там и заказов), но убрали бы эти дурачкие балльл. Я всё равно их ни на что практически не менял» (информант № 11, мужчина, работник, торговый представитель). И, конечно, среди полученных данных было много информации о том, как работникам нравится накапливать баллы и обменивать их на призы. Значит, можно сделать вывод о том, что стремление к накоплению баллов все же мотивирует работников выполнять рабочие задачи в игровой форме.

Если говорить об изменении отношения к выполнению рабочих обязанностей, то, по утверждению руководства, общая производительность труда повысилась ${ }^{10}$, и сотрудники в целом стали активнее выполнять дополнительные задания (например, «подключение к различным акциям торговых точек»). Однако такие результаты наводят на мысль о наличии в данном случае «хоторнского эффекта», замеченного впервые Э. Мэйо при проведении в 1924-1932 гг. исследований компанией Western Electric на заводе Hawthorne Works в США (см. подробнее: [Мауо 1963: 161-182]). Хоторнский эффект — это условия, в которых новизна, интерес к эксперименту или повышенное внимание к данному вопросу приводят к искажённому, зачастую слишком благоприятному результату. При этом участники эксперимента действуют иначе, более усердно, чем обычно, только благодаря осознанию того, что они причастны к эксперименту [Adair 1984].

Возможно, в случае внедрения геймификации как открыто предложенного работникам эксперимента возникает аналогичный эффект: позитивные изменения в поведении работников вызваны исключительно оказанным им вниманием, которое сами люди истолковывают как «уникальную» возможность стать участниками инновационного эксперимента. Таким образом, в данном случае положительно на отношение к работе влияют не только вознаграждение (призы) и стремление к победе, но осознание важности причастности к эксперименту и ощущение внимания со сторонь руководства и других работников.

\section{Контроль над трудовым процессом со стороны работников}

Принято считать, что вся деятельность по контролю над трудовым процессом находится исключительно в компетенции управляющих менеджеров, в то время как рядовые работники - объекты манипулирования, которых следует контролировать, и их трудовую деятельность необходимо стимулировать. Однако в действительности работники зачастую используют собственные стратегии установления контроля над трудовым процессом, которые порой противоречат планам руководства, что, в свою очередь, может провоцировать конфликтные ситуации.

В ситуации с изменением условий труда возникают различные практики сопротивления инновационным правилам игры и обмана системы. Например, один из информантов признался:

Забыл я один раз сделать фотографию в торговой точке до расстановки бутылок на полке, а если этого не сделать, то вообще визит не засчитают <...> приилось идти в соседний магазин и делать фотографию там ${ }^{11}$ (информант № 15, мужчина, работник, торговый представитель).

10 Руководство оценивает показатели производительности труда каждого сотрудника и всего отдела в целом ежеквартально.

11 Приложение фиксирует корректный визит в TT, если GPRS-координаты загруженного фото не далее, чем в 300 м от расположения ТТ на карте, то есть погрешность измерения в этом приложении равна приблизительно 300 м, что позволяет загружать фото из других магазинов в этом радиусе (данные из инструкции к приложению «Город»). 
Также был зафиксирован интересный случай, когда работник в погоне за победой в соревнованиях пошёл на обман системы подсчёта баллов:

У нас в прошлом году была акиия для ТT: при заказе двух ящиков водки «N» хозяин TT получает сертификат номиналом 300 рублей на покупку продукиии в нашем фирменном магазине, а мне за подключение к акиии каждой ТТ дают по три балла. Так я в некоторых магазинах отметил в смете заказ, система мне это засчитала, балль зачислились, а я потом заказ отметил как ошибочный, но балль не списали <...> Потом они заметили этот баг, когда кто-то пожаловался, наверное, но меня не наказали, их же косяк (информант № 4, мужчина, работник, торговый представитель).

Таким образом, мы выявили две стратегии пассивного сопротивления новым условиям труда:

— обман и фальсификация, то есть стремление победить любой ценой, прибегая к фальсификации данных отчётов о работе и обману системы;

- формальное участие, то есть добросовестное выполнение минимальных трудовых обязанностей, но отсутствие стремления к конкурентной борьбе и перевыполнению плана.

Эти стратегии являются противоположными: первая предполагает стремление к перевыполнению плана, а вторая — нет.

\section{Влияние геймификации на социальный климат в коллективе}

Изучаемый нами принцип контроля над трудовым процессом не предполагает наличия открытых конфликтов между работниками и контролирующим их руководством. Вероятно, этот факт можно объяснить тем, что в связи с практически полной автоматизацией отчётной деятельности торговых представителей для них отпала необходимость часто появляться в офисе компании и лично встречаться с руководством, которое могло бы высказать замечания в устной форме. Однако личные встречи с руководством и со всеми сотрудниками сохранились, они проводятся в конце каждого месяца и несут положительный заряд. В рамках этих встреч происходят обсуждение «успехов» сотрудников и публичное награждение победителей дополнительными призами за высокие места в рейтингах разных категорий. Таким образом, геймификация направлена на минимизацию личного общения между работниками и руководством, что даёт положительный эффект: меньше публичных обсуждений ошибок, следовательно, больше обсуждений успехов и в результате - улучшение отношений между работниками и начальством. Однако при этом внедрённая в работу развлекательная игра, которая в теории должна способствовать всеобщему веселью и сплотить коллектив, в действительности предполагает дезинтеграцию в рабочем коллективе, спровоцированную снижением личного общения как с руководством, так и между работниками.

Более того, общей дезинтеграции также способствует направленность геймификации на обострение конкурентной борьбы, что усиливает негативное влияние на социальный климат в коллективе.

Например, некоторые информанты (№ 5, мужчина, работник, торговый представитель и № 13, женщина, работник, торговый представитель) признались, что недовольны тем, что их «особенно амбициозные коллеги» стремятся к призовым местам в рейтингах, чтобы «покрасоваться перед начальством», при этом они могут недобросовестно выполнять те рабочие задания, за которые не дают дополнительных призовых баллов. Разобщению коллектива и снижению мотивации работников способствует наличие несправедливости (например, один работник считает, что его поощряют и хвалят меньше, чем 
его коллегу, который менее квалифицированный). Таким образом, по данным интервью, оказалось, что открытая конкурентная борьба может провоцировать конфликтные ситуации, которые связаны с претензиями, вызванными «несправедливой оценкой достижений». Было зафиксировано недовольство со стороны опытных сотрудников, имевших хорошие показатели труда до внедрения новой системы оценки достижений, но после её внедрения активно не участвовавших в игре и не получавших дополнительного вознаграждения. Их недовольства сводятся к следующему:

Новички, пришедшие на работу после внедрения «Города», направляют слишком много энергии на эти соревнования и значки <... Их поощряют на летучках < .. > а опыта работы у них вообще нет, не могут даже правила выкладки запомнить (информант № 12, женщина, работник, торговый представитель).

Получается, что поощрения и похвалу со стороны руководства получают не самые лучше работники, а самые лучше игроки, и это не всем сотрудникам кажется справедливым способом оценки заслуг. В текущей ситуации при существовании геймифицированных практик контроля над работниками молодые, неопытные, но готовые к инновациям сотрудники станут получать больше поощрений от руководства, чем те опытные сотрудники, которые не смогли адаптироваться к изменениям, что, конечно, обостряет социальное напряжение в коллективе. И объяснить подобную реакцию можно с точки зрения теории справедливости Дж. Адамса, утверждающего, что взаимосвязь между полученным вознаграждением и затраченными усилиями оценивается работниками с субъективной точки зрения, а затем они сравнивают свои результаты и поощрения с результатами и поощрениями других работников [Adams 1965]. Иначе говоря, сущность данной теории заключается в том, что мотивация работников повышается при наличии желания получить справедливое вознаграждение. В то время как мы наблюдаем обратную картину: мотивация работников выполнять даже обязательные рабочие задачи и общая удовлетворённость условиями труда понижаются из-за наличия несправедливой оценки достижений.

Таким образом, на практике геймификация эффективна с точки зрения повышения мотивации и вовлечённости сотрудников, однако существует риск ухудшения социального климата в коллективе.

\section{Заключение}

Сложное сочетание пост- и неофордистских методов в современной управленческой практике и их противоречивые последствия для работников, а также переплетение социальных и трудовых отношений на предприятии представляют собой важную социальную и исследовательскую проблему. В рамках данной работы эта проблема была рассмотрена на примере сравнительно новой управленческой практики - геймификации.

Геймификация задействует игровые механики - наборы правил, заимствованных из социальных онлайн-игр и предназначенных для поощрения и стимулирования работников.

Анализ функционирования геймификации и её влияния на трудовое поведение был проведён на примере кейса отдельной компании, что, естественно, накладывает ограничения на возможности генерализации выводов. Тем не менее мы полагаем, что выбранный кейс является показательным примером использования геймификации для управления персоналом, так как в изучаемой организации этот механизм имеет классический характер и достаточно давно используется.

В результате после изучения основных принципов механизма управления в рассматриваемой компании было выявлено, что руководство позиционирует геймификацию как способ мотивации персонала. Во многом менеджменту действительно удалось достичь желаемого результата: играющие сотрудники выражали различные мнения насчёт изменений условий труда, но преимущественно положительные. 
Вместе с тем, очевидно, геймификация в первую очередь является инструментом контроля над трудовым процессом (своего рода современной модификацией тейлористско-фордистской системы), в основе которого лежит автоматизация и алгоритмизация деятельности работников. Для снижения недовольства работников выполнением рутинных задач их рабочая деятельность встроена в компьютерную игру, которая предполагает соревнование между участниками за дополнительное вознаграждение. При этом участие обязательно, так как выполнение даже минимальных рабочих обязанностей происходит с помощью специализированного игрового приложения. Внедрение компьютерных технологий для автоматизации рабочих операций в работу способствует организации электронного принуждения. Более того, публикация результатов игры и соответственно работы, автоматически осуществляемая в этом приложении, делает все успехи и неудачи публичными. Этот факт говорит о том, что на практике геймификация направлена на создание тотального контроля со стороны как руководства, так и других работников и, в частности, на самоконтроль.

Показательно при этом то, что не было категорически негативных отзывов о новом формате работы. И большинству работников определённо нравится получать дополнительное вознаграждение и приобретать его в игровом формате, добиваясь преимущества над коллегами. Значит, наличие конкурентной борьбы может быть фактором, стимулирующим работников активнее участвовать в игре ради победы и вознаграждения; при этом участники взаимодействия мотивированы выполнять больше заданий. Виртуальная система поощрения в совокупности со стремлением к победе также способствует повышению вовлечённости работников и синхронизации их задач с целью организации. При этом обладание брендированной продукцией и сувенирами способствует повышению лояльности к организации. Руководство также отмечает повышение регулярно замеряемых показателей производительности труда.

Внедрение игрового элемента в трудовой процесс не повлекло возникновения открытых конфликтов между руководством и работниками. Однако с появлением новой геймифицированной системы контроля над трудовым процессом со стороны рабочих могут быть инициированы такие практики пассивного сопротивления, как фальсификация (подмена данных о выполненной работе для победы в игре) и формальное участие (нежелание перевыполнять план). Кроме того, существует риск ухудшения социального климата в коллективе, спровоцированный открытой конкурентной борьбой и «несправедливой оценкой достижений».

В целом геймификация представляет собой интересный гибрид на стыке управленческих практик пости неофордизма. По-видимому, соотношение между ними ситуативно и может сильно варьироваться в разных организациях. Дальнейшие исследования геймификации в различных контекстах смогли бы прояснить этот вопрос.

\section{Литература}

Врум В. 1964. Труд и мотивация. М.: Наука.

Зикерманн Г., Линдер Д. 2014. Геймификаџия в бизнесе: как пробиться сквозь шум и завладеть вниманием сотрудников и клиентов. М.: Манн, Иванов и Фербер.

Инглхарт Р., Вельцель К. 2011. Модернизация, культурные изменения и демократия: последовательность человеческого развития. М.: Новое издательство.

Иноземцев В. Л. 1997. Творческие начала современной корпорации. Мировая экономика и международные отношения. 11: 18-30. 
Иноземцев В. 1998. За пределами экономического общества. Постиндустриальные теории и постэкономические тенденичи в современном мире. М.: Academia; Наука.

Радаев В. В. 2005. Экономическая сочиология. М.: Изд. дом ВШЭ.

Страусс А., Корбин Дж. 2001. Основы качественного исследования: обоснованная теория, процедурь и техники. Пер. с англ. и послесловие Т. С. Васильевой. М.: Эдиториал УРСС.

Тейлор Ф. 1991. Принцииь научного менеджмента. М.: Контроллинг.

Цыплакова Е. О. 2013. Анализ случая внедрения механизма социального влияния «gamification» в сфере привлечения потенциальных потребителей: кейс L'Oreal. Дальневосточный вестник. 4 (24): 54-59.

Шевчук А. В. 2010. Границы автономии: феномен «зависимой» самозанятости. Социологический журнал. 3: 35-51. URL: http://jour.isras.ru/upload/journals/1/articles/1157/submission/original/1157-2179-1-SM. pdf

Шевчук А. В. 2002. Постфордистские концепции как исследовательская программа. Экономическая социология. 3 (2): 44-61. URL: https://ecsoc.hse.ru/data/2011/12/08/1208205032/ecsoc_t3_n2.pdf\#page=44

Adair J. 1984. The Hawthorne Effect: A Reconsideration of the Methodological Artifact. Journal of Applied Psychology. 62 (2): 334-345.

Adams J. S. 1965. Inequity in Social Exchange. Advances in Experimental Social Psychology. 2: 267-299.

Aiello J., Kolb K. 1995. Electronic Performance Monitoring and Social Context: Impact on Productivity and Stress. Journal of Applied Psychology. 80 (3): 339-353.

Braverman H. 1974. Labor and Monopoly Capital: The Degradation of Work in the Twentieth Century. New York: Monthly Review Press.

Dale S. 2014. Gamification Making Work Fun, or Making Fun of Work? Business Information Review. 3 (2): 82-90.

Deterding S. et al. 2011a. From Game Design Elements to Gamefulness: Defining Gamification. In: Proceedings of the 15th International Academic MindTrek Conference: Envisioning Future Media Environments. New York, NY, USA: ACM; 9-15. URL: http:/gamification-research.org/2012/04/defining-gamification/

Deterding S. et al. 2011b. Gamification: Using Game Design Elements in Non-Gaming Contexts. In: $C H I$ 2011 Workshop Gamification. May, 7-12. Vancouver, Canada; 2-5. URL: http:/gamification-research.org/ wp-content/uploads/2011/04/01-Deterding-Sicart-Nacke-OHara-Dixon.pdf

Dewinter J., Kocurek C. A., Nichols R. 2014. Taylorism 2.0: Gamification, Scientific Management and the Capitalist Appropriation of Play. Journal of Gaming \& Virtual Worlds. 6 (2): 109-127.

Dignan A. 2011. Game Frame: Using Games as a Strategy for Success. New York: Free Press; 16-19.

Edwards R. 1979. Contested Terrain: The Transformation of the Workplace in the Twentieth Century. London: Heinemann. 
Frang K., Mellstrand R. 2011. Enterprise Gamification of the Employee Development Process at an Infocom Consultancy Company. Lund, Sweden: Lunds University; 124-132.

Fried Y. et al. 2007. Job Design in Temporal Context: A Career Dynamics Perspective. Journal of Organizational Behavior. 23 (3): 911-927.

Foucault M. 1977. Discipline and Punish: The Birth of the Prison. New York: Vintage Books.

Given K. 2011. Gaming For Good: The Gamification of Social Change. Greenmarketing. 4: 4-15.

Hackman J. R., Oldham G. R. 1976. Motivation through the Design of Work: Test of a Theory. Organizational Behavior and Human Performance. 16 (2): 250-279.

Jacobs H. B. 2013. Gamification: A Framework for the Workplace. A Dissertation. Master of Science. The University of Liverpool. URL: https://www.google.com/?gws_rd=ssl\#q=Jacobs+H.+B.+2013.+Gamifica tion:+A+Framework+for+the+Workplace

Kapp K. M. 2012. Games, Gamification, and the Quest for Learner Engagement. T+ D. 66 (3): 31-35.

Kark R. 2011. Games Managers Play: Play as a Form of Leadership Development. Academy of Management Learning \& Education. 10 (3): 507-527.

Lyon D. (ed.) 2003. Surveillance as Social Sorting: Privacy, Risk, and Digital Discrimination. London; New York: Routledge.

Mayo E. 2009. Hawthorne and the Western Electric Company. Public Administration: Concepts and Cases. Boston: Harvard Business Press; 149-157.

Mollick E. R., Rothbard N. 2014. Mandatory Fun: Consent, Gamification and the Impact of Games at Work. The Wharton School Research Paper Series. 21 (1): 3-54.

Porter L., Lawler E. 1968. Managerial Attitudes and Performance. Homewood, III: Irvin.

Sewell G. 1998. The Discipline of Teams: The Control of Team-Based Industrial Work Through Electronic and Peer Surveillance. Administrative Science Quarterly. 43 (2): 397-428.

Taylor P., Bain P. 1999. «An Assembly Line in the Head»: Work and Employee Relations in the Call-Centre. Industrial Relations Journal. 30 (2): 5-23.

Weckert J. (ed.) 2005. Electronic Monitoring in the Workplace: Controversies and Solutions. Melbourne: Idea Group Publishing.

Zichermann G., Cunningham C. 2011. Gamification by Design: Implementing Game Mechanics in Web and Mobile Apps. URL: http://gamification.co/tag/gabe-zichermann/

Zweig D., Webster J., Scott K. A. 2008. Making the Decision to Monitor in the Workplace: Cybernetic Models and the Illusion of Control. In: Hodgkinson G. P., Starbuck W. H. (eds) The Oxford Handbook of Organizational Decision Making. Oxford, England: Oxford University Press; 116-133. 


\title{
DEBUT STUDIES
}

\section{Elena Tcyplakova}

\section{Gamification - the Way of Motivation or Way of Control over the Labor Process?}

\author{
TCYPLAKOVA Elena - \\ Senior Product Analyst, \\ LoyaltyPlant Russia. \\ Address: 15 Chkalovsky \\ pr., Saint-Petersburg \\ 197110, Russian \\ Federation.
}

\section{Email: tsyplakova elena@mail.ru}

\begin{abstract}
The paper presents results of sociological research that analyzed the new way of controlling the labor process - gamification. This study was based on a concept of post-Fordism and neo-Fordism and focused on examining a combination of the game elements for motivation and electronic surveillance. According to industrial sociology traditions, special attention was paid to strengthening control over workers and social and labor conflicts.
\end{abstract}

This research was based on data from 16 semi-structured interviews with the managers and employees of a Russian company that produces alcoholic beverages. Data analysis was made using the principles of grounded theory.

As a result, one positive of introducing gamification was the successful combination of the virtual system and the workers' desire to win, which promoted the employees' increased involvement in the labor process. In general, introducing gamification didn't lead to open conflicts between the managers and workers; however, changes in the organization of the labor process and technical difficulties instigated passive ways of resisting new working conditions. Deterioration of the social climate was collective because the aggravated competition between workers also led to negative consequences.

As a result, it was revealed that although gamification is positioned as a motivator, in reality, it is primarily a way to exert total control over the labor process, which is organized by automatic operations and electronic monitoring. A distinctive feature of this method is the use of gaming elements to vary routine activities and disguise negative aspects in the whole mechanism.

Keywords: gamification; work and motivation; labor process; control over workers; electronic surveillance; electronic monitoring.

\section{Acknowledgements}

The article is based on the MA Thesis "Gamification as a Way of Motivation and Control over the Labor Process (case of spirits company)" submitted to the School of Sociology, HSE in 2015. Thesis supervisor A. Shevchuk, Candidate of Economic Sciences, Associate Professor of School of Sociology, Senior Research Fellow, Laboratory for Studies in Economic Sociology, HSE.

\section{References}

Adair J. (1984) The Hawthorne Effect: A Reconsideration of the Methodological Artifact. Journal of Applied Psychology, vol. 62, no 2, pp. 334-345. 
Adams J. S. (1965) Inequity in Social Exchange. Advances in Experimental Social Psychology, no 2, pp. 267299.

Aiello J. Kolb K. (1995) Electronic Performance Monitoring and Social Context: Impact on Productivity and Stress. Journal of Applied Psychology, vol. 80, no 3, pp. 339-353.

Braverman H. (1974) Labor and Monopoly Capital: The Degradation of Work in the Twentieth Century. New York: Monthly Review Press.

Dale S. (2014) Gamification Making Work Fun, or Making Fun of Work? Business Information Review, vol. 3, no 2, pp. 82-90.

Deterding S., Dixon D., Khaled R., Nacke L. (2011) From Game Design Elements to Gamefulness: Defining Gamification. Proceedings of the 15th International Academic MindTrek Conference: Envisioning Future Media Environments, New York, NY, USA: ACM, pp. 9-15. Available at: http://gamification-research. org/2012/04/defining-gamification/ (accessed 9 May 2016).

Deterding S., O’Hara K., Sicart M., Dixon D., Nacke L. (2011) Gamification: Using Game Design Elements in Non-Gaming Contexts. CHI 2011 Workshop Gamification, May, 7-12. Vancouver, Canada, pp. 2-5. Available at: http://gamification-research.org/wp-content/uploads/2011/04/01-Deterding-Sicart-Nacke-OHaraDixon.pdf (accessed 9 May 2016).

Dewinter J., Kocurek C. A., Nichols R. (2014) Taylorism 2.0: Gamification, Scientific Management and the Capitalist Appropriation of Play. Journal of Gaming \& Virtual Worlds, vol. 6, no 2, pp. 109-127.

Edwards R. (1979). Contested Terrain: The Transformation of the Workplace in the Twentieth Century, London: Heinemann.

Inglehart R., Weltzel C. (2011) Modernizatsiya, kul 'turnye izmeneniya i demokratiya: Posledovatel'nost'chelovecheskogo razvitiya [Modernization, Cultural Changes and Democracy: Succession of Human Development], Moscow: Novoe izdatel'stvo (in Russian).

Inozemtsev V. L. (1997) Tvorcheskie nachala sovremennoy korporatsii [Creative Foundations of the Modern Corporation]. Mirovaya ekonomika i mezhdunarodnye otnosheniya, no 11, pp. 8-30 (in Russian).

Inozemtsev V. (1998) Za predelami ekonomicheskogo obshchestva. Postindustrial'nye teorii i postekonomicheskie tendentsii v sovremennom mire [Beyond the Economic Society. Postindustrial Trends in the Modern World], Moscow: Academia; Nauka, pp. 114-115 (in Russian).

Frang K., Mellstrand R. (2011) Enterprise Gamification of the Employee Development Process at an Infocom Consultancy Company, Lund, Sweden: Lunds University, pp. 124-132.

Fried Y., Grant A., Levi A., Hadan M., Slowik L.H. (2007) Job Design in Temporal Context: A Career Dynamics Perspective. Journal of Organizational Behavior, vol. 23, no 3, pp. 911-927.

Foucault M. (1977) Discipline and Punish: The Birth of the Prison, New York: Vintage Books.

Given K. (2011) Gaming For Good: The Gamification of Social Change. Greenmarketing, no 4, pp. 4-15. 
Hackman J. R., Oldham G. R. (1976) Motivation through the Design of Work: Test of a Theory. Organizational Behavior and Human Performance, vol. 16, no 2, pp. 250-279.

Jacobs H. B. (2013) Gamification: A Framework for the Workplace. A Dissertation. Master of Science. The University of Liverpool. Available at: https:/www.google.com/?gws_rd=ssl\#q=Jacobs + H. + B. +2013 . +Gamification:+A+Framework+for+the+Workplace (accessed 5 May 2016).

Kapp K. M. (2012) Games, Gamification, and the Quest for Learner Engagement. $T+D$, vol. 66, no 3, pp. 3135 .

Kark R. (2011) Games Managers Play: Play as a Form of Leadership Development. Academy of Management Learning \& Education, vol. 10, no 3, pp. 507-527.

Lyon D. (ed.) (2003) Surveillance as Social Sorting: Privacy, Risk, and Digital Discrimination, London; New York: Routledge.

Mayo E. (2009) Hawthorne and the Western Electric Company. Public Administration: Concepts and Cases. Boston: Harvard Business Press, pp.149-157.

Mollick E. R., Rothbard N. (2014) Mandatory Fun: Consent, Gamification and the Impact of Games at Work. The Wharton School Research Paper Series, vol. 21, no 1, pp. 3-54.

Porter L., Lawler E. (1968) Managerial Attitudes and Performance, Homewood, III: Irvin.

Radaev V. V. (2005) Ekonomicheskaya sotsiologiya [Economic Sociology], Moscow: HSE Publishing House, pp. 269-299 (in Russian).

Strauss A., Corbin J. (2001). Osnovy kachestvennogo issledovaniya: obosnovannaya teoriya, protsedury $i$ tekhniki [Basics of Qualitative Research: Techniques and Procedures for Developing Grounded Theory] (Russian trans.; afterword T. S. Vasil'evoy), Moscow: Editorial URSS (in Russian).

Sewell G. (1998) The Discipline of Teams: The Control of Team-Based Industrial Work Through Electronic and Peer Surveillance. Administrative Science Quarterly, vol. 43, no 2, pp. 397-428.

Shevchuk A. V. (2002). Postfordistskie kontseptsii kak issledovatel'skaya programma [Post-Fordism Concepts as Research Program], Journal of Economic Sociology = Ekonomicheskaya sotsiologiya, vol. 3, no 2, pp. 44-61. Available at: https://ecsoc.hse.ru/data/2011/12/08/1208205032/ecsoc_t3_n2.pdf\#page=44 (accessed 9 May 2016) (in Russian).

Shevchuk A. V. (2010) Granitsy avtonomii: fenomen «zavisimoy» samozanyatosti [Borders of Autonomity: A Phenpmenon of "Dependent Self-Employment"]. Sotsiologicheskiy zhurnal, no 3, pp. 44. Available at: http://jour.isras.ru/upload/journals/1/articles/1157/submission/original/1157-2179-1-SM.pdf (accessed 9 May 2016) (in Russian).

Taylor P. (1991) Printsipy nauchnogo menedzhmenta [The Principles of Scientific Management], Moscow: Kontrolling (in Russian).

Taylor P., Bain P. (1999) An Assembly Line in the Head: Work and Employee Relations in the Call-Centre. Industrial Relations Journal, vol. 30, no 2, pp. 5-23. 
Tsyplakova E. O. (2013) Analiz sluchaya vnedreniya mekhanizma sotsial'nogo vliyaniya «Gamification» v sfere privlecheniya potentsial'nykh potrebiteley: keys L'Oreal [An Analysis of Implementation of "Gamification" and Its Impact on Potential Consumer Engagement: The Case of L'Oreal]. Dal'nevostochnyy vestnik, vol. 4, no 24, pp. 54-59 (in Russian).

Vroom V. (1964) Trud i motivatsiya [Work and Motivation], Moscow: Nauka (in Russian.)

Weckert J. (2004) Electronic Monitoring in the Workplace: Controversies and Solutions: Controversies and Solutions, Melbourne: Idea Group Publishing.

Zichermann G., Cunningham C. (2011) Gamification by Design: Implementing Game Mechanics in Web and Mobile Apps. Available at: http:/gamification.co/tag/gabe-zichermann/ (accessed 14 May 2014)

Zickermann G., Linder J. (2014) Geymifikatsiya v biznese: Kak probit'sya skvoz'shum i zavladet'vnimaniem sotrudnikov i klientov [Gemification in Business: How to Get Through Noise and to Engage Customers and Employees], Moscow: Mann, Ivanov i Ferber (in Russian).

Zweig D., Webster J., Scott K. A. (2008) Making the Decision to Monitor in the Workplace: Cybernetic Models and the Illusion of Control. The Oxford Handbook of Organizational Decision Making (eds. G. P. Hodgkinson, W. H. Starbuck), Oxford, England: Oxford University Press, pp. 116-133.

Received: December 8, 2015.

Citation: Tcyplakova E. (2016) Geymifikatsiya - motivatsionnaya praktika ili mekhanizm total'nogo kontrolya nad trudovym protsessom? [Gamification - the Way of Motivation or Way of Control over the Labor Process?]. Journal of Economic Sociology = Ekonomicheskaya sotsiologiya, vol. 17, no 3, pp. 82-109. Available at: https://ecsoc.hse.ru/2016-17-3.html (in Russian). 


\title{
ПРОФЕССИОНАЛЬНЫЕ ОБЗОРЫ
}

\author{
М. М. Сакаева
}

\section{Права собственности в фокусе социологических теорий: через размывание границ к междисциплинарности}

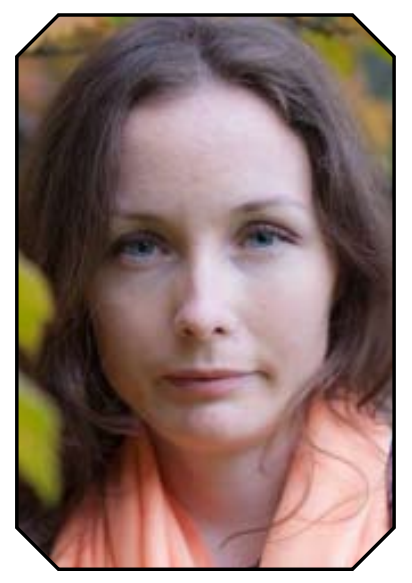

САКАЕВА Мария Маратовна - кандидат социологических наук, магистр социологии Европейского университета в СанктПетербурге, заместитель директора экспертноаналитического центра Ухтинского государственного технического университета. Адрес: 169300, Россия, Коми, Ухта, ул. Первомайская, д. 13.

\section{Email: eu.sakaeva@} gmail.com
В обзоре представлены основные теоретические подходы к анализу прав собственности, разработанные в социальных науках. Условия появления и развития этого института рассматриваются с экономических, социологических и междисциплинарных позиций. Особое внимание уделяется неоинституционалистам во главе с Д. Нортом. Волна критики со стороны сочиологов и антропологов не просто показала, что в XXI веке неоинституцииональное понимание природы прав собственности не всегда релевантно, но и способствовала расивету междисциплинарности в этом поле. Пока политическая экономия изучала роль государства в защите собственности, новая институциональная экономика фокусировалась на институционализачии частной собственности, а социальная антропология искала культурные основания отношений собственности, сочиологам было непросто обосновывать своё включение в дискуссию о правах собственности. Результатом активизации представителей социиальных наук стало ослабление позищий экономистов либерального толка с их склонностью к нормативности и к идеализаџии частной собственности. Социологи показали, что права собственности - это больше, чем экономика; собственность влияет на культуру и право, государство и общество, коллективное и индивидуальное и одновременно зависит от них. Сочиологические исследования последних лет, с одной стороны, включили в пространство собственнических отношений немало новых объектов (например, торговую марку или женское тело). С другой стороны, социологи показали влияние правовых рамок и сочиальных норм на конфигурачию участников отношений собственности, специфику их интересов и взаимодействия. Обзор начинается с проблематизачии понятий «право собственности» $u$ «собственность» с акиеетом на деконструкиию категории «собственность» 6 соииологии. Далее представлено обоснование роли государства в развитии частной собственности и защите собственников, предложенное новой институциональной теорией. Критика апологетов частной собственности переходит в анализ концепций, обосновывающих значимость культуры в институционализации прав собственности и многообразие отношений собственности в современном мире. В заключение рассмотрены исследования о способах защиты прав собственности в условиях институциональной нестабильности.

Ключевые слова: права собственности; частная собственность; социология собственности; государство; рынок; новый институционализм; политическая экономия. 


\section{Введение}

В экономической теории не так много категорий, которые за сравнительно короткий период подверглись многомерной разработке и даже деконструкции со стороны социологов и представителей других социальных наук. К ним относятся права собственности. При этом социологи недостаточно уверенно чувствуют себя в этом исследовательском поле, хотя постоянно с разных сторон изучают проблемы, порождаемые институтом собственности. Анализ теорий собственности и подходов к концептуализации прав собственности в общем итоге показывает согласие экономистов и социологов с тем, что собственность - это больше, чем экономика. В конце XX века экономсоциологи указывали на то, что диадная модель упускает из поля зрения социальное и политическое измерение собственности, описывает идеальную схему, а не реальность [Fligstein 2001]. Если частная собственность и появляется в форме диадных отношений, то на практике речь всегда идёт о триадных отношениях, поскольку собственность как феномен и права на неё со стороны социального агента возникают тогда, когда другие признают право социального агента на исключительный контроль собственности, управление ею и её использование напрямую либо через законодательство [Curruthers, Ariovich 2004].

В XIX веке классики политической экономии рассматривали собственность в социологическом измерении, не только как территорию взаимодействия между индивидами и группами по поводу присвоения и использования ресурсов, но и как основание социальной стратификации. По К. Марксу, распространение частной собственности обусловливает воспроизводство социального неравенства, особенно при капитализме [Маркс 2003]. Новая институциональная экономическая теория выступала против вмешательства государства в экономику, но признавала, что сложные формы обмена невозможны без участия государства. Неоинституционалисты поэтому включили в исследовательскую модель государство, право и закон.

Экономисты А. Алчиан и Г. Демзетс ещё в 1973 г. писали о повышенном внимании к правам собственности в мире науки, о разнообразии подходов к анализу социальных проблем, порождаемых капитализмом и частной собственностью. Они же указывали на то, что многие вопросы остаются без ответа, в частности те, которые касаются структуры прав собственности, социальных условий их функционирования и развития во времени [Alchian, Demsetz 1973]. Спустя четверть века экономсоциологи попрежнему обеспокоены недостаточным вниманием представителей социальных наук к правам собственности - они изучают, по сути, проблемы вокруг института собственности, а не внутри него [Fligstein 2001; Swedberg 2003]. Отчасти поэтому экономисты чувствуют себя в этом поле довольно уверенно [Barzel 1989; Eggertsson 1996; Тамбовцев 2009]. Но движение науки в сторону междисциплинарности и целый пласт социологических исследований, показывающих влияние культурного и социального контекстов, политических и правовых рамок на реальные отношения собственности, обусловливают не просто ослабление нормативных позиций экономистов, но и существенную реконструкцию их собственного подхода к правам собственности.

Цель обзора состоит в определении основных направлений исследований, связанных с концептуализацией понятий «собственность» и «право собственности», их развитием в рамках социальных наук. Обзор начинается с проблематизации конструирования самого понятия «право собственности». Далее представлены результаты размывания дисциплинарных границ и деконструкции категории «собственность» в социальных науках, что в итоге обусловило разнообразие предметного и проблемного полей. После этого проанализирована аргументация сторонников включения культурного и социального контекстов в современные исследования прав собственности с акцентом на опыте перехода постсоветских стран к рынку. Успехи и провалы новых рыночных экономик не в последнюю очередь обусловили внимание исследователей к культурным факторам институционализации прав собственности, усилили остроту дискуссий между сторонниками либеральной и цивилизационной парадигм собственности. 
В заключение речь идёт о взглядах экономсоциологов на основные проблемы с правами собственности в России и на способы защиты частной собственности, которые используют участники рынка в условиях институциональной нестабильности.

\section{Собственность и право собственности: проблема конструирования понятий}

Категория «права собственности» настолько прочно вошла в научный язык, что само сочетание понятий «право» и «собственность», казалось бы, не вызывает вопросов. Однако, по замечанию авторитетного отечественного экономиста Р. И. Капелюшникова, учёные вынужденно используют понятие «право собственности», поскольку в обыденном языке «собственность» употребляется в значении «объект собственности» [Капелюшников 2004].

Неоклассическая экономическая теория разрабатывала несколько основных тем относительно прав собственности. Во-первых, под собственностью понимается не ресурс или материальный объект, а пучок прав по использованию ресурса [Alchian, Demsetz 1973]. Во-вторых, в теории собственности речь идёт не об отношениях «индивид - вещь», а об отношениях между людьми по поводу использования редких благ [Капелюшников 2004]. В этом смысле Р. Капелюшников опровергает критику новой институциональной экономики [Эггертссон 2001; Фуруботн, Рихтер 2005] в адрес неоклассиков в том, что они под отношениями собственности не подразумевали отношения между людьми [Капелюшников 2004]. Более того, неоклассики признавали, что эти отношения санкционированы обществом, но необязательно государством, а это предполагает несение издержек в случае нарушения правил игры. Закрепление прав собственности одновременно формальными и неформальными нормами является третьей темой, которая волновала экономистов [Капелюшников 2004].

Права собственности возникают в связи с проблемой редкости благ и ограниченности доступа к ним. Ресурс или благо становится собственностью, когда группа или индивид заявляют свои притязания на исключительное их использование и способны эти притязания защищать. В этом смысле понятия «собственность» и «право» органично связаны. Право возникает там и тогда, где и когда у индивида появляются некие ограничения по свободному использованию благ, ресурсов или возможностей. Как справедливо отмечает Г. Сапов, «атаки на собственность всегда оказываются атаками на принцип свободы» [Сапов 2004]. Индивидуальная свобода и собственность были предметом философских дискуссий. Сапов, апеллируя к политическим философам либерального толка (Дж. Локк, Т. Пейн, Т. Джефферсон), в качестве универсальной составляющей собственности отмечает принцип свободы [Сапов 2004]. Классики политической философии не использовали понятие «право собственности», оно появилось значительно позже. Пока же, в XVII веке, Дж. Локк пишет о «правиле собственности». Суть его состоит в том, что каждый человек должен иметь столько, сколько он может использовать; ресурс, который он исключает из общего достояния, и приводит к возникновению собственности [Собственность классиков... 2004].

В новой институциональной экономической теории праву собственности придаётся более широкий смысл, который выходит как за рамки юридической концепции, так и за рамки неоклассического подхода, поскольку включает социальные нормы [Эггертссон 2001: 48]. Более того, именно неоинституционалисты сделали собственность предметом анализа, перестали воспринимать её как нечто данное, подходили к собственности как к результату взаимодействия различных агентов в ситуации неопределённости под влиянием внешних факторов [Фуруботн, Рихтер 2005]. Причиной критики в адрес неоклассиков со стороны новой институциональной школы был их нормативизм, несоответствие модели реальности, в которой права могут быть нечётко определены, формы собственности - смешаны или пограничны, а издержки агентских отношений трудно просчитать [Фуруботн, Рихтер 2005]. 
Неоинституционалисты подчёркивали необходимость участия государства в обеспечении прав собственности при одновременном ограничении его вмешательства в экономику. Одних санкций, будь их источником государство или общество, недостаточно для создания безопасных условий реализации прав собственности. Т. Эггертссон указывает на соответствие между социальными нормами и формальными правилами игры в сфере собственности, которые устанавливает государство. В противном случае возникают конкурирующие схемы прав собственности [Эггертссон 2001: 50-51].

Сама процедура определения прав, будь то право собственности или право голосовать, многосложна. У. Райкер и И. Сенед выделяли два уровня определения прав [Riker, Sened 1991]. На первом уровне права понимаются как комбинация обязанностей со стороны правопредставителя (bearer) и требований со стороны правообладателя (holder). Если первый из них обязуется соблюдать установленные нормы использования прав, то второй определяет требования и заинтересован в качестве их соблюдения. На втором уровне появляется новый игрок - государство. Оно должно обеспечивать институциональные условия соблюдения прав правообладателя (собственника), прежде всего со стороны чиновников [Riker, Sened 1991: 953].

$\mathrm{C}$ конца $\mathrm{XX}$ века в социологии и антропологии предпринимаются попытки и вовсе деконструировать понятие «собственность», когда сугубо социальные явления переводятся в рыночную плоскость, социальные группы маркируются в категориях товара. Большой вклад в деконструкцию внесло феминистское течение в гендерной теории. Исследования в этой области показали, почему в патриархальной культуре укоренялось отношение к женщине как к товару, через какие механизмы и практики женщина становилась объектом присвоения, распоряжения и реципрокного обмена [Печески 2000, Рубин 2000]. Ряд феминистских исследований о коммодификации женского тела анализируют отдельные его составляющие в категориях собственности, а репродуктивные процессы преломляют сквозь призму рыночных отношений, когда, например, яйцеклетка или женское тело становится товаром в контексте суррогатного материнства [Sharp 2000; Waldby, Cooper 2006].

На сегодняшний день успел сложиться целый сегмент социологических и антропологических исследований медицинских рынков, где объектом собственности, то есть предметом купли, продажи или дарения могут быть органы и ткани человека, включая криминальные рынки донорских органов [Healy 2000; Scheper-Hughes 2000; Steiner 2003]. Даже жизнь может стать предметом коммерциализации и отношений собственности [Drahos 1999].

Всплеск цифровых технологий спровоцировал изучение новых форм собственности, прежде всего собственности интеллектуальной. Патенты на компьютерные программы, виртуальные сервисы, виртуализация бизнеса, инновационные продукты, торговые марки и бренды, музыкальное и кинопиратство в Интернете - это лишь часть вопросов в поле интеллектуальной собственности. К ним обращаются главным образом западные исследователи, дополнительно включая их в контекст расовой дискриминации, моральной экономики [Hesse 2002; Hall 2003; Podlas 2010; Emerson 2014].

\section{Права собственности: государство имеет значение}

Расширение дисциплинарных границ изучения прав собственности уходит корнями в труды классиков социологии, подчёркивавших значимость политического и социального контекста развития этого института в разных обществах (К. Маркс, М. Вебер, Э. Дюркгейм). Но тогда речь шла в первую очередь о частной собственности как об одном из оснований социального неравенства в эпоху капитализма. Сторонники классового анализа и сегодня полагают устойчивость имущественного неравенства и укрепление государственных институтов эксплуатации и контроля главным негативным последствием института частной собственности [Roemer 1989; Earle 2000; Keister, Moller 2000]. 
Согласно классикам экономической науки, отношения собственности включают три составляющие это собственник, предмет собственности и не собственник. Представители новой экономической школы в начале 1990-х гг. заявили не просто об участии большего количества акторов в отношениях собственности, но и о необходимости восхождения с микроуровня на макроуровень анализа. Права собственности начали рассматривать как территорию взаимоотношений между правительством и населением, государством и бизнесом [Elster 1989; Норт 1997]. Обратившись к истории развития экономических институтов, Д. Норт и Б. Вайнгаст включили государство в анализ правособственнических институтов [North, Weingast 1996]. Экономистов интересовало создание и функционирование институтов и организаций, которые защищают собственника от государства [Milgrom, Greif, Weingast 1994]. На примере противостояния английской королевской власти и парламента в XVII веке они рассмотрели, как ограничение полномочий правительства (limited government) ускорило экономическое развитие [North, Weingast 1996].

Признавалась значимость государства не только в обеспечении гарантий прав собственности [Riker, Sened 1991; North 1993; North, Weingast 1996], но и в развитии рынков в целом, что в итоге определяет жизнеспособность капитализма [Fligstein 2001]. Н. Флигстин на примере развития Силиконовой долины в США показал, как в результате вмешательства государства развивались конкретные рынки [Fligstein 2001].

Некоторые неоинституционалисты вовсе объясняют появление государства необходимостью защиты прав собственности. Как утверждает Т. Эггертссон, по мере имущественной дифференциации и ресурсного дефицита, для защиты прав собственности было недостаточно группового насилия и социальных сетей. Потребовалось появление государства в роли монопольного отправителя насилия [Эггертссон 2001: 330-332].

Для Д. Норта институты даже в случае сбоев и неудач если и зло, то необходимое: без них невозможны порядок и экономическое развитие [Норт 1997]. Такой взгляд не лишён романтизма: Норт был уверен, что «плохие» институты сменяются «хорошими», следование правилам и нормам приносит пользу, а появление норм обусловлено их социальной полезностью. Ю. Эльстер, напротив, не всегда видел пользу в соблюдении норм. Влияние нормы - положительное или отрицательное - можно понять только после её внедрения и укоренения. Общество и государство, создавая институты, участвуют в лотерее. Если норма окажется «хорошей», то страна придёт к экономическому росту и всеобщему процветанию; «плохие» нормы ведут к упадку [Elster 1989].

Представители новой институциональной экономики были далеки от наивных убеждений в том, что права собственности могут гарантироваться только формальными методами [Капелюшников 2004]. Они понимали признание права не только как поведение, соответствующее или противоречащее формальным правилам. Если право собственности не уважается и не признаётся другими (в частности, чиновниками), легальное владение правом не есть институт [Weimer 1997].

Почему в одних государствах права собственности чётко определены и надёжно защищены, а в других - нет? Почему одни общества оправдывают посягательство на частную собственность, а другие успешны в борьбе с правовым нигилизмом? Многое зависит от надёжности гарантий прав собственности. Надёжные гарантии (credible commitment) понимаются как ограничения, нацеленные на формирование убеждений экономических агентов по поводу действий государства относительно управления ресурсами [Diemeier et al. 1997: 23]. Представители неоинституциональной экономики были убеждены, что государство является главным гарантом частной собственности [North 1993]. Государство, решая главную дилемму экономической политики - защищать или грабить [Weingast 1997], должно ограждать от насилия, создавая эффективные суды, полицию и бюрократию [Frye 2004: 454]. 


\section{Разнообразие отношений собственности: роль культурных факторов}

По мере нарастания внимания представителей социальных наук к проблемам собственности всё больше сторонников находила позиция, объясняющая разный уровень защиты собственности в странах мира разницей социальных норм, социальных отношений между акторами. Категорию культуры в анализ прав собственности включили разработчики когнитивного подхода [Riker, Sened 1991; Bardhan 2005; Jacobs 2005]. Они настаивают на том, что необходимо учитывать поведение индивидов, систему их ценностей и установок, которая, в конечном счёте, определяет эффективность внедрения тех или иных институтов.

Эти исследователи тоже попали в ловушку этатизма, возлагая большие надежды на государство. По мнению У. Райкера и И. Сенеда, сторонников когнитивного подхода, для стабильной реализации индивидами прав собственности важно уважение и признание этого явления в обществе, прежде всего со стороны государственных агентов [Riker, Sened 1991: 955]. Высказывалась вера в способность государства создавать эффективную структуру мотивов, которая сдерживала бы оппортунистическое поведение бюрократии [Мое 1984: 756]. Как отмечает С. Ломан, если государство гарантирует выполнение взятых обязательств, то создаётся репутационный механизм гарантий прав собственности (цит. по: [Bardhan 2005: 40]).

Критикуя институционалистов, А. Якобс отмечал, что когнитивная составляющая (восприятие) не менее важна, чем структурное (законодательное) оформление права собственности. Произвол есть культурно обусловленное явление: чиновники не уважают частную собственность, отказываются признавать её неприкосновенность [Jacobs 2005]. Если экономисты рассматривали нормы и институты как нечто внешнее по отношению к индивидам и группам, то социологи помещали институт внутрь человека. Нормы тотальны: они включают и эмоциональный элемент. Нельзя отделять игроков от правил, а институты — от отношения игроков к ним [Elster 1989].

Антропологов также интересовало культурное измерение прав собственности. Они рассматривали институт частной собственности и саму собственность как культурно обусловленные явления в том смысле, что они представляют собой производное так называемого западного мира или эпохи модерна с их стремлением к экономическому росту, индивидуальному материальному успеху. В традиционных обществах и культурах идея частной собственности по сути своей чужеродна системе ценностей и норм. У коренных народов нет понятия «частная собственность» [Bright 1995]. Адаптация современного законодательства о правах собственности в Китае была затруднена в связи с тем, что законы и культура Китайской империи содержали специфическую идею собственности [Alford 1995]. Коренное население Америки не относилось к земле в категориях частной собственности; это исключительно европейские ценностные стандарты [McEvoy 1998].

Антропологические и социологические исследования земельных отношений показывают подвижность и размытость границ между формами собственности и в индустриальных обществах, когда содержание понятий «собственность» и «право собственности» по-разному понимаются и конструируются. «Полем боя» групп интересов, действующих с позиций разных идеологических установок и культурных представлений, может стать город [Галиндабаева 2014], олимпийская стройка [Карбаинов 2012] или дачный участок [Касаткина 2015]. Неразрешённость вопроса о том, кто на самом деле владеет землёй и иными объектами собственности, культурные противоречия между рынком и общиной, реальными владельцами и юридическими собственниками провоцируют споры на территориях традиционного землепользования [Stammler, Wilson 2006; Тулаева 2014]. 
В результате взаимовлияния социальных отношений, культурных норм, правового поля, государства и рынка складывается континуум отношений собственности. Как институт собственность не только выполняет экономические функции, но одновременно провоцирует и разрешает социальные конфликты [Azuela 2007; Benda-Beckmann, Benda-Beckmann, Wiber 2009].

\section{Либеральная и цивилизационная парадигмы собственности}

Исследовательская повестка относительно роли государства в защите прав собственности значительно обновилась в 1980-1990-х гг. в связи с переходом социалистических стран к рынку. Противоречивость этого процесса, разнообразие планов и результатов приватизации и либеральных реформ, направленных в том числе на создание института частной собственности, — всё это подогрело интерес к правам собственности со стороны представителей новой политической экономии. В литературе, «политизировавшей» таким образом экономическое явление, хорошо изучены итоги рыночных реформ в странах Центральной и Восточной Европы [Diemeier et al. 1997; Dobek 1997; Boettke 2003; Bardhan 2005].

В дискуссиях о частной собственности сформировались два исследовательских лагеря; конфронтацию между ними и обострил опыт перехода некоторых стран к рынку. Исследователи либерального толка признавали существенное отклонение институтов частной собственности от западных образцов в бывших плановых экономиках и предлагали рецепты институционального строительства, призванного, в конечном счёте, обеспечить успешный переход к рынку. Представители новой политической экономии также обращались к проблеме минимизации угроз правам собственности со стороны так называемого грабительского государства [Shleifer, Vishny 1998; Hellman, Geraint, Kaufmann 2012].

Цивилизационный подход, альтернативный либеральному, выступает против механического насаждения института частной собственности в тех обществах, чья культурная специфика и исторический контекст отличались от западного пути, основанного на демократии и верховенстве права. В рамках цивилизационного подхода хорошо разработана теория власти-собственности, которая нашла наиболее яркое воплощение в России. Термин был предложен историком-востоковедом Л. С. Васильевым для обозначения такой природы права на собственность, когда оно является производным от должностного положения лица в структурах государства [Васильев 2005: 69-70]. На Востоке ${ }^{1}$ «собственность рождается как функция владения и власти. Власть-собственность - это не столько собственность, сколько власть, так как функции собственника здесь опосредованы причастностью к власти, то есть к должности» [Васильев 2005: 69-70].

Есть мнение, что, поскольку цивилизационная матрица власть-собственность успешно воспроизводится даже в условиях рынка, нужно отказаться от дальнейших дискуссий об институционализации частной собственности в западном, либеральном её понимании, а модернизироваться в пределах возможностей, доступных в условиях особого российского пути [Нуреев, Латов 2015; Плискевич 2015]. По мнению О. Э. Бессоновой, институциональную матрицу России по-прежнему составляет не рынок, а «раздаток» [Бессонова 2006]. В отечественной социологии популярна теория зависимости от предшествующего развития (path dependency), с которой органично сочетается теория власти-собственности.

Продолжаются дискуссии о специфической ментальности российского общества, что обрекает на провал реформы по западному образцу. В частности, С. Г. Кирдина относит Россию к типу восточной матрицы ( $X$-матрица), отличной от матрицы западной ( $Y$-матрица) (см.: [Тамбовцев 2009]). Однако отмечается, что социальное поведение определяет не только институциональная среда, но и доминирующие в обществе убеждения, ценности и традиции [Александров, Кирдина 2012]. Неудачу рыночных

1 Речь идёт о Востоке как об историко-культурном, социополитическом и цивилизационном феномене. Предметом востоковедения был первоначально весь неевропейский мир; см. подробнее: [Васильев 2005: 17-21]. 
реформ С. Г. Кордонский связывает не с зависимостью от предшествующего развития и не с отторжением рыночных элементов специфической национальной почвой, а с тем, что настоящий рынок невыгоден правящему классу и статусным группам, поскольку он может угрожать их привилегированному положению [Кордонский 2008].

Социологические трактовки власти-собственности пересекаются с уже упомянутой теорией грабительского государства, основная идея которой состоит в том, что государство обладает достаточной силой как для защиты собственности, так и для конфискации богатства граждан [Shleifer, Vishny 1998; Hellman, Geraint, Kaufmann 2012]. Но в системе власти-собственности изначально право распоряжаться ресурсами и имуществом монопольно принадлежит государству. Теория грабительского государства описывает явления, имевшие место на Западе, когда государство посягало на частную собственность, реализуя себя в роли «грабителя», а не «защитника» [Robinson 1998; Frye, Yakovlev, Yasin 2009]. Teoрия власти-собственности аргументирует статусную обусловленность доступа к экономическим ресурсам, а также отражает реалии, при которых граница между государством и рынком, коллективным и индивидуальным достаточно условна.

\section{Защита прав собственности: взгляд экономсоциологов}

Переход постсоветских стран к рынку не только обострил дискуссию о природе частной собственности и её зависимости от культурно-исторического контекста. Актуализировался вопрос о защите прав собственности, когда предприниматели оказываются между двух огней. С одной стороны, государство практикует различные формы давления на бизнес, используя для этого чрезмерное налоговое бремя и даже вымогательство [Frye 2002a; Firestone 2008; Frye, Yakovlev, Yasin 2009; Яковлев 2013]. С другой стороны, зафиксирована устойчивость теневизации бизнеса, когда он создаёт независимую от государства зону суверенности [Хамфри 2010] или адаптирует закон под себя [Журавская 2011]. Оппортунизм бизнеса стал отдельной темой социологических исследований, куда входит широкий спектр дисциплин - от экономической социологии [Hendley, Murrell, Ryterman 2000; Панеях 2013] до правоведения [Соломон-мл. 2013]. Надо добавить к этому работы о месте организованной преступности на формирующихся рынках, что было общим местом становления капитализма на постсоветском пространстве [Frye 2002a].

Слабость государства и многообразие угроз обусловили развитие практик частной защиты, когда участники рынка прибегали к услугам специальных агентов. Наиболее полно агенты и практики частной защиты проанализированы при исследовании силового предпринимательства [Волков 2002]. Т. Фрай пришёл к выводу о функциональной значимости частных охранников для благополучия малого бизнеса: они не только защищают от рэкетиров, но и принуждают контрагентов к соблюдению контрактов, помогают пополнять клиентскую базу. Т. Фрай выделил ещё одну причину спроса на частную защиту: произвольное применение правил регулирования со стороны представителей государства [Frye 2002b: 573].

В посткоммунистических обществах сложилась не просто система частной защиты, но экономика рэкета. При таком типе экономики значительны издержки защиты прав собственности от посягательств отдельных лиц и организованных групп [Латов 2003]. Силовая защита бизнеса доминирует на определённом этапе становления предпринимательства, пока акторы оказываются сильнее институтов, а нелегальность пронизывает все сферы общества. В этом смысле опыт России не является уникальным, аналогичные процессы происходили, например, в Италии [Гамбетта 1993] и в Перу [Сото 1995].

Через призму концепции контроля Н. Флигстина [Fligstein 2001] покупку услуг частных правоохранителей можно рассматривать как способ стабилизации рынка. В бизнесе существовали представления 
о том, что «крыша» эффективнее государственной защиты. Как указывает А. Портес, в неформальной экономике нет места государству, поскольку для него этот сектор невидим [Портес 2003: 41]. Обратное правило гласит, что легальный бизнес логичным образом требует легальных способов защиты. Неслучайно по мере легализации бизнеса в конце 1990-х — начале 2000-х гг. спрос на бандитские «крыши» начал падать [Волков 2002].

Экономическая социология также предложила свой взгляд на участие бизнеса в политике, которое бывает прямым и косвенным. Косвенное участие варьируется от финансирования избирательной кампании политической партии до лоббирования интересов фирмы через должностное лицо за определённое вознаграждение [Барсукова, Звягинцев 2006; Faccio 2006].

Прямое участие подразумевает приход бизнесменов в органы исполнительной и законодательной власти, когда они официально становятся представителями политико-административной элиты. В последние годы в России отмечен рост числа представителей бизнеса в составе региональных парламентов и муниципальных собраний депутатов [Расторгуев 2012; Левин, Каган, Кислицын 2014].

Исследование роли депутатского статуса в предпринимательской деятельности показывает широкий набор возможностей для развития бизнеса, а также для защиты от угроз, производимых рынком и государством [Сакаева 2012]. Необязательно обладать формальным статусом, чтобы получать выгоды для бизнеса от приближённости к власти. Как показывают локальные практики, участники рынка вынуждены тратить время и усилия на выстраивание сетей, на включение в клуб «своих» бизнесменов, приближенных к власти. Это открывает доступ к тем или иным привилегиям [Левин, Курбатова 2011].

Депутатский статус от таких издержек освобождает, но обостряет значимость социальных отношений и персонального доверия в структурах власти, от которых зависят горизонты эксклюзивных ресурсов и возможностей, позволяющих укреплять положение на рынке. Причём социальный капитал, доверие и репутация нередко являются основаниями конвертации депутатского статуса в экономические выгоды. Это характерно как для столичного мегаполиса [Сакаева 2012], так и для регионов [Сакаева 2015].

В некотором смысле депутатский статус заменяет институт частной защиты. Напомним, что Т. Фрай выделял такие функции частных охранников, как защита от рэкетиров, принуждение к соблюдению контрактов и др. [Frye 2002b: 571-573].

\section{Заключение}

Трудно переоценить вклад социологов в то, что в последние годы всё более очевидной становится расхождение между идеальной моделью частной собственности и реальными отношениями собственности. То, что сторонники либеральной парадигмы выдавали за институт частной собственности, оказалось на деле только идеей прав собственности [Benda-Beckmann, Benda-Beckmann, Wiber 2009]. Социологический подход показал, что институт собственности куда более многообразен, чем предлагаемая либеральными экономистами дихотомия коллективного и индивидуального, частного и государственного. Частная собственность не есть панацея от болезней переходного периода и не является гарантией общественного благосостояния. Даже на Западе институт частной собственности далеко не всегда соответствует идеальным образцам, сконструированным рыночными апологетами, как, впрочем, и сам рынок [Fligstein 2001].

В то же время социологический подход к правам собственности является своего рода мостом между экономической теорией, с одной стороны, и политической экономией и новой институциональной тео- 
рией - с другой. Первых интересует микроуровень, когда права собственности рассматриваются как отношения между автономными рациональными индивидами. Политэкономы и неоинституционалисты подходят к правам собственности как к продукту государственного строительства и институциональных реформ. Если одни недооценивают внешнюю среду и роль государства в экономике, то другие, отталкиваясь от либеральных идей, парадоксальным образом превращают государство в Левиафана.

Представители социологического лагеря, который в данном обзоре был представлен широко, включая социологов, антропологов, экономсоциологов и правоведов, убедительно показали, что взгляд на собственность как на продукт социальных отношений и культурного процесса позволяет включать в круг исследований широкий набор объектов и проблем. С одной стороны, критика либеральной концепции частной собственности вскрыла многообразие отношений собственности в разных типах обществ, их зависимость от институционального дизайна, культурных норм. Антропологический поворот привлёк внимание к отношениям собственности вне государственного контроля, когда государство слабо либо его присутствие в повседневной жизни минимально (как в случае современных коренных народов). С другой стороны, размывание понятия «собственность» за счёт включения в дискурс о собственности тех объектов, которые так или иначе могут маркироваться как товар (например, женское тело или жизнь), не лишено спекулятивности. В результате, в частности, стираются границы между социологией рынка и социологией прав собственности, при том что обе эти дисциплины находятся в процессе становления и поиска исследовательского фокуса. Вместе с тем, претерпевая всё большее предметное и дисциплинарное расширение, права собственности и отношения собственности в своём многообразии открывают новые возможности не только перед социологами, но и перед экономистами, позволяют и тем и другим отражать изменения современного общества.

\section{Литература}

Александров Ю. И., Кирдина С. Г. 2012. Типы ментальности и институциональные матрицы: мультидисциплинарный подход. Социологические исследования. 8: 3-12.

Барсукова С. Ю., Звягинцев В. И. 2006. Механизм «политического инвестирования», или Как и зачем бизнес участвует в выборах и оплачивает партийную жизнь. Экономическая социология. 7 (2): 8-22. URL: https://ecsoc.hse.ru/2006-7-2.html

Бессонова О. Э. 2006. Раздаточная экономика России: эволющия через трансформащии. М.: РОССПЭН.

Васильев Л. С. 2005. История Востока. Учебник: В 2 т. Т. 1. М.: Высшая школа.

Вебер М. 2002. Протестантская этика и дух капитализма. Ивано-Франковск: Ист-Вью.

Волков В. В. 2002. Силовое предпринимательство. СПб.: Летний сад.

Галиндабаева В. И. 2014. Мегасобытия в постсоветских городах: неопатримониальные машины роста и присвоение государственной собственности. Журнал соџиологии и сощиальной антропологии. 1 : $126-140$.

Гамбетта Д. 1993. Рэкет как нелегальный правоохранительный бизнес. Журнал «Экономическая теория преступлений и наказаний». 1. URL: http://corruption.rsuh.ru/magazine/1/n1-09.shtml

Дюркгейм Э. 1996. О разделении общеественного труда. М.: Канон. 
Журавская Т. Н. 2011. «Серый импорт» в Благовещенске: что нового? Экономическая соииология. 12 (1): 54-71. URL: https://ecsoc.hse.ru/2011-12-1.html

Капелюшников Р. И. 2004. Право собственности (очерк современной теории). Отечественные записки. 6. URL: http://www.strana-oz.ru/2004/6/pravo-sobstvennosti-ocherk-sovremennoy-teorii

Карбаинов Н. И. 2012. Изъятие неформальной собственности в России: негативные уроки подготовки к Олимпийским играм в Сочи. Серия «Аналитические записки по проблемам правоприменения». СПб.: ИПП ЕУСПб.

Касаткина А. К. 2015. Частная собственность и коллективное товарищество. Режимы собственности и социальные отношения в садоводческих некоммерческих товариществах Ленинградской области 2000-х годов. Журнал сочуиологии и соџиальной антропологии. 1: 163-178.

Кордонский С. Г. 2008. Сословная структура постсоветской России. М.: Институт Фонда «Общественное мнение».

Латов Ю. В. 2003. «Экономика рэкета» в постсоветской России. Интернет-конференция «Поиск эффективных институтов для России XXI века». URL: http://ecsocman.hse.ru/text/16214862/

Левин С. Н., Курбатова М. В. 2011. Сетевые взаимосвязи российского бизнеса: деловая коррупция и органический институт реальной модели институциональной организации российской экономики. Журнал институциональных исследований. 3 (2): 50-69.

Левин С. Н., Каган Е. С., Кислицын Д. В. 2014. Интернализованный политический ресурс крупного бизнеса в Кузбассе. ЭКО. 1: 85-94.

Маркс К. 2003. Капитал. Критика политической экономии. Т. 1. М.: ЭКСМО.

Норт Д. 1997. Институты, институциональные изменения и функиионирование экономики. М.: Начала.

Нуреев Р. М., Латов Ю. В. 2015. Постсоветское институциональное развитие: в поисках выхода из колеи власти-собственности. Мир России. 2: 50-88.

Панеях Э. Л. 2013. Зарегулированное государство. Pro et Contra. 17 (1-2): 79-92.

Печески Р. 2000. Аборт и выбор женщины: государство, сексуальность и репродуктивные права. В сб.: Гапова Е., Усманова А. (сост.) Антология гендерной теории. Минск: Пропилеи; 141-150.

Плискевич Н. М. 2015. Трансформации системы власти-собственности в России: региональный аспект. Могут ли регионы начать свой путь к модернизации. Мир России. 2: 89-104.

Поланьи К. 2002. Великая трансформация: политические и экономические истоки нашего времени. М.: Алетейя.

Портес А. 2003. Неформальная экономика и её парадоксы. Экономическая соииология. 4 (5): 34-53. URL: https://ecsoc.hse.ru/2003-4-5.html 
Расторгуев С. В. 2012. Инкумбенты-бизнесмены в областной законодательной власти в ЦФО в 20002011 гг. Политические исследования. 4: 117-125.

Рубин Г. 2000. Обмен женщинами: заметки по политэкономии пола. В сб.: Гапова Е., Усманова А. (сост.) Антология гендерной теории. Минск: Пропилеи; 99-117.

Сакаева М. М. 2012. Парламент как «окно возможностей»: исследование поведения предпринимателей с депутатским мандатом в ходе реализации рыночных интересов. Экономическая сочиология. 13 (3): 96-123. URL: https://ecsoc.hse.ru/2012-13-3.html

Сакаева М. М. 2015. Спрос предпринимателей на социальный капитал в поле рынка и политики. Журнал сочиологии и сощиальной антропологии. 1: 110-122.

Сапов Г. 2004. Собственность: условия человеческой деятельности и юридическая категория. Oтечественные записки. 6. URL: http://www.strana-oz.ru/2004/6

Собственность классиков: Джон Локк. 2004. Отечественные записки. 6. URL: http://www.strana-oz. $\mathrm{ru} / 2004 / 6$

Соломон-мл. П. Г. 2013. Уголовное преследование и регулирование бизнеса: прекращение российской исключительности и культивирование верховенства права. В сб.: Новикова Е. B. et al. (ред.) Верховенство права как фактор экономики. М.: Фонд «Либеральная миссия»; 413-430.

Сото Э. де. 1995. Иной путь. Невидимая революиия в третьем мире. Пер. с англ. Б. Пинскера. М.: Catallaxy.

Тамбовцев В. Л. (ред.) 2009. Права собственности, приватизаџия и наџионализащия в России. М.: Фонд «Либеральная миссия».

Тулаева С. А. 2014. Нефтяные компании, оленеводческие сообщества и местные органы власти: права на землю с перспективы разных стейкхолдеров. Журнал соџчологии и соичильной антропологии. 5 : $141-157$

Фуруботн Э., Рихтер Р. 2005. Институты и экономическая теория: достижения новой институциональной экономической теории. СПб.: Издательский дом СПбГУ.

Хамфри К. 2010. Постсоветские трансформации в Азиатской части России. М.: Наталис.

Эггертссон Т. 2001. Экономическое поведение и институты. М.: Дело.

Яковлев А. А. 2013. Отнять или создать? Стимулы к применению насилия в экономике и факторы, способные его ограничить. В сб.: Новикова Е. В. et al. (ред.) Верховенство права как фактор экономики. М.: Фонд «Либеральная миссия»; 121-143.

Alchian A., Demsetz H. 1973. The Property Right Paradigm. The Journal of Economic History. 33 (1): 1627.

Alford P. 1995. To Steal a Book Is an Elegant Offense: Intellectual Property Law in Chinese Civilization. Stanford: Stanford University Press. 
Azuela A. Sociological Analysis of Property. 2007. In: Clark D. (ed.) Encyclopedia of Law and Society: American and Global Perspectives. Los Angeles: Sage Publications.

Bardhan P. 2005. Scarcity, Conflicts and Cooperation: Essays in the Political and Institutional Economics of Development. Cambridge, MA: MIT Press.

Barzel Y. 1989. Economic Analysis of Property Rights. Cambridge: Cambridge University Press.

Benda-Beckmann F. von, Benda-Beckmann K. von, Wiber M. 2009. The Properties of Property. In: BendaBeckmann F. von, Benda-Beckmann K. von, Wiber M. (eds) Changing Properties of Property. Oxford: Berghahn; 1-39.

Boettke P. 2003. Calculation and Coordination. Essays on Socialist and Transitional Political Economy. New York: Taylor \& Francis Library.

Bright C. 1995. Who Owns Indigenous Peoples’ DNA? Humanist. 55 (1): 44-63.

Curruthers B., Ariovich L. 2004. The Sociology of Property Rights. Annual Review of Sociology. 30: $23-46$.

Diemeier D. et al. 1997. Credible Commitment and Property Rights: Strategic Interaction between Political and Economic Actors. In: Weimer D. (ed.) The Political Economy of Property Rights. Institutional Change and Credibility in the Reforms of Centrally Planned Economics. Cambridge: Cambridge University Press; $20-43$.

Dobek M. 1997. Property Rights and Institutional Changes in the Czech and Slovak Republics. In: Weimer D. (ed.) The Political Economy of Property Rights. Institutional Change and Credibility in the Reforms of Centrally Planned Economics. Cambridge: Cambridge University Press; 182-205.

Drahos P. 1999. Biotechnology Patents, Markets and Morality. European Intellectual Property Review. 21 (9): 441-449.

Jacobs A. 2005. A Matter of Trust: Cognition, Institutions and the Sources of Credible Commitment. Research Working Paper. URL: http://faculty.arts.ubc.ca/jacobs

Earle T. 2000. Archeology, Property, and Prehistory. Annual Review Anthropology. 29: 39-60.

Eggertsson T. 1996. A Note on the Economics of Institutions. In: Alston L., Eggertsson T., North D. (eds) Empirical Studies in Institutional Change. Cambridge: Cambridge University Press; 6-25.

Elster J. 1989. Social Norms and Economic Theory. The Journal of Economic Perspectives. 3 (4): 89-117.

Emerson R. 2014. Franchises as Moral Rights. Wake Forest Intellectual Property Law Journal. 14 (4): $540-577$.

Faccio M. 2006. Politically Connected Firms. The American Economic Review. 96 (1): 369-386.

Firestone T. 2008. Criminal Corporate Raiding in Russia. International Lawyer. 42 (4): 1207-1229.

Fligstein N. 2001. The Architecture of Markets: An Economic Sociology of Twenty First-Century Capitalist Societies. Princeton: Princeton University Press. 
Frye T. 2002a. Capture or Exchange? Business Lobbying in Russia. Europe-Asia Studies. 54 (7): 1017-1036.

Frye T. 2002b. Private Protection in Russia and Poland. American Journal of Political Science. 46 (3): 572-584.

Frye T. 2004. Credible Commitment and Property Rights: Evidence from Russia. The American Political Science Review. 98 (3): 453-466.

Frye T., Yakovlev A., Yasin Y. 2009. The other Russian Economy: How Everyday Firms View the Rules of the Game in Russia. Social Research. 76 (1): 29-54.

Hall B. 2003. Business Method Patents, Innovation and Policy. Working Paper No 9717. Cambridge, MA: National Bureau of Economic Research. URL: http://www.nber.org/papers/w9717.pdf

Healy K. 2000. Sacred Markets and Secular Ritual in the Organ Transplant Industry. American Journal of Sociology of the Economy. 105: 1633-1657.

Hendley K., Murrell P., Ryterman R. 2000. Law, Relationships and Private Enforcement: Transactional Strategies of Russian Enterprises. Europe-Asia Studies. 52 (4): 627-656.

Hellman S., Geraint J., Kaufmann D. 2000. Seize the State, Seize the Day: An Empirical Analysis of State Capture and Corruption in Transition Economies. Research Working Paper No 2444. Washington, DC: World Bank.

Hesse C. 2002. The Rise of Intellectual Property, 700 B.C. - A.D. 2000: An Idea in the Balance. Doedalus. 131 (Spring): 228-251.

Keister L., Moller S. 2000. Wealth Inequality in the United States. Annual Reviews Sociology. 26: 63-81.

McEvoy A. 1998. Markets and Ethics in U.S. Property Law. In: Jacobs M. (ed.) Who Owns America? Social Conflict over Property Rights. Madison: University Wisconsin Press; 94-113.

Milgrom P., Greif A., Weingast B. 1994. Coordination, Commitment, Enforcement: the Case of the Merchant Guild. The Journal of Political Economy. 102 (4): 745-766.

Moe T. 1984. The New Economics of Organization. American Journal of Political Science. 28 (4): 739-777.

North D. 1993. Institutions and Credible Commitment. Journal of Institutional and Theoretical Economics. 149 (1): 11-23.

North D., Weingast B. 1996. Constitutions and Commitment: the Evolution of Institutions Governing Public Choice in 17th Century England. In: Alston L., Eggertsson T., North D. (eds) Empirical Studies in Institutional Change. Cambridge: Cambridge University Press; 134-166.

Podlas K. 2010. The Moral of the Story... Musical Artists Must Protect their Own Rights in Digital Music. Wake Forest Intellectual Property Law Journal. 10 (3): 265-288. 
Riker W., Sened I. 1991. A Political Theory of the Origin of Property Rights: Airport Slots. American Journal of Political Science. 35 (4): 951-969.

Roemer J. 1989. What is Exploitation? Philosophy Public Affairs. 18: 90-97.

Robinson J. 1998. Theories of "Bad Policy”. Journal of Political Reforms. 1: 1-46.

Scheper-Hughes N. 2000. The Global Traffic of Human Organs. Current Anthropology. 41 (2): 191-224.

Sharp L. 2000. The Commodification of the Body and Its Parts. Annual Reviews Anthropology. 29: 287-328.

Shleifer A., Vishny R. 1998. The Grabbing Hand: Government Pathologies and Their Cures. Cambridge, MA: MIT Press.

Stammler F., Wilson E. 2006. Dialog for Development: en Exploration of Relations Between Oil and Gas Companies, Communities and the State. Sibirica. 5 (2): 1-42.

Steiner P. 2003. Gifts of Blood and Organs: The Market and "Fictitious" Commodities. Revue Francaise de Sociologie. Supplement: An Annual English Selection. 44: 147-162.

Swedberg R. 2003. Principles of Economic Sociology. Princeton: Princeton University Press.

Waldby C., Cooper M. 2006. The Biopolitics of Reproduction: Post-Fordist Biotechnology and Women's Clinical Labour. Working Paper No 15. London: Global Biopolitics Research Group.

Weimer D. 1997. The Political Economy of Property Rights. In: Weimer D. (ed.) The Political Economy of property Rights. Institutional Change and Credibility in the Reforms of Centrally Planned Economics. Cambridge: Cambridge University Press; 1-20.

Weingast B. 1997. The Political Commitment to Markets and Marketization. In: Weimer D. (ed.) The Political Economy of Property Rights. Institutional Change and Credibility in the Reforms of Centrally Planned Economics. Cambridge: Cambridge University Press; 43-50. 


\section{PROFESSIONAL REVIEWS}

\section{Maria Sakaeva}

\section{Property Rights in the Focus of Social Theories: Through Breaking Boundaries towards Interdisciplinary}

\section{SAKAEVA, Maria - \\ Candidate of Sciences in Sociology, Master in Sociology of European University at Saint-Petersburg, Deputy Director, Centre of Expertise and Analytics, Ukhta State Technical University. Address: 13 Pervomayskaya str., Ukhta, 169300, Russian Federation.}

Email: eu.sakaeva@gmail. com

erty is not restricted to economic sphere, that it depends on and influences culture and law, state and society, collective and individual. The list of property types was enlarged due to recent sociological studies. For example, the female body and trademark were both discussed in terms of property. The first part of the article reviews notions of "property" and "property rights" and a deconstruction of "property" by sociologists. The second part deals with the state's role in the development of private property and the problem of property protection, discussed within the framework of new institutionalism. Then the article examines economic and sociological concepts, which explain why culture matters for property relations, and the article describes the diversity of property relations in practice. Finally, ways of protecting property rights under the institutional instability are analyzed.

Keywords: property rights; private property; sociology of property; state; market; new institutionalism; political economy.

\section{References}

Alchian A., Demsetz H. (1973) The Property Right Paradigm. The Journal of Economic History, vol. 33, no 1, pp. 16-27.

Aleksandrov J. I., Kirdina S. G. (2012) Tipy mental'nosti i institutsional'nye matritsy: multidistsiplinarny podkhod [Mental Types and Institutional Matrix: Multidisciplinary Approach]. Sotsiologicheskie issledovaniya, no 8, pp. 3-12 (in Russian).

Alford P. (1995) To Steal a Book Is an Elegant Offense: Intellectual Property Law in Chinese Civilization, Stanford: Stanford University Press. 
Azuela A. (2007) Sociological Analysis of Property. Encyclopedia of Law and Society: American and Global Perspectives (ed. D. Clark), Los Angeles: Sage Publications, pp. 344-361.

Barsukova S., Zvyagintsev V. (2006) Mekhanizm "politicheskogo investirovaniya”, ili Kak i zachem biznes uchastvuet v vyborakh i oplachivaet partiynuyu zhizn' [Mechanism of Political Investments or How and Why Business Participate in Elections and Finance Party Life]. Journal of Economic Sociology $=$ Ekonomicheskaya sotsiologiya, vol. 7, no 2, pp. 8-22. Available at: https://ecsoc.hse.ru/2006-7-2.html (accessed 16 May 2016) (in Russian).

Bardhan P. (2005) Scarcity, Conflicts and Cooperation: Essays in the Political and Institutional Economics of Development, Cambridge, MA: MIT Press.

Barzel Y. (1989) Economic Analysis of Property Rights, Cambridge: Cambridge University Press.

Benda-Beckmann F. von, Benda-Beckmann K. von, Wiber M. (2009) The Properties of Property. Changing Properties of Property (eds F. Benda-Beckmann von, K. Benda-Beckmann von, M. Wiber), Oxford: Berghahn, pp. 1-39.

Bessonova O.E. (2006) Razdatochnaya ekonomika Rossii: evolyutsiya cherez transformatsii [Raztatochnaya Russian Economy:The Conceptual Analysis], Moscow: ROSSPEN Publishers (in Russian).

Boettke P. (2003) Calculation and Coordination. Essays on Socialist and Transitional Political Economy, New York: Taylor \& Francis Library.

Bright C. (1995) Who Owns Indigenous Peoples’ DNA? Humanist, vol. 55, no 1, pp. 44-63.

Curruthers B., Ariovich L. (2004) The Sociology of Property Rights. Annual Review of Sociology, vol. 30, pp. 23-46.

Diemeier D., Ericson J., Frye T., Lewis S. (1997) Credible Commitment and Property Rights: Strategic Interaction between Political and Economic Actors. The Political Economy of Property Rights. Institutional Change and Credibility in the Reforms of Centrally Planned Economies (ed. D. Weimer), Cambridge: Cambridge University Press, pp. 20-43.

Dobek M. (1997) Property Rights and Institutional Changes in the Czech and Slovak Republics. The Political Economy of Property Rights. Institutional Change and Credibility in the Reforms of Centrally Planned Economics (ed. D. Weimer), Cambridge: Cambridge University Press, pp. 182-205.

Drahos P. (1999) Biotechnology Patents, Markets and Morality. European Intellectual Property Review, vol. 21, no 9, pp. 441-449.

Durkheim E. (1996) O razdelenii obshchestvennogo truda [The Division of Labor in Society], Moscow: Kanon (in Russian).

Earle T. (2000) Archeology, Property, and Prehistory. Annual Review Anthropology, no 29, pp. 39-60.

Eggertsson T. (1996) A Note on the Economics of Institutions. Empirical Studies in Institutional Change (eds L. Alston, T. Eggertsson, D. North), Cambridge: Cambridge University Press, pp. 6-25. 
Eggertsson T. (2001) Ekonomicheskoe povedenie i instituty [Economic Behavior and Institutions], Moscow: Delo (in Russian).

Elster J. (1989) Social Norms and Economic Theory. The Journal of Economic Perspectives, vol. 3, no 4, pp. 89-117.

Emerson R. (2014) Franchises as Moral Rights. Wake Forest Intellectual Property Law Journal, vol. 4, no 4, pp. $540-577$.

Faccio M. (2006) Politically Connected Firms. The American Economic Review, vol. 96, no 1, pp. 369-386.

Firestone T. (2008) Criminal Corporate Raiding in Russia. International Lawyer, vol. 42, no 4, pp. $1207-$ 1229.

Fligstein N. (2001) The Architecture of Markets: An Economic Sociology of Twenty First-Century Capitalist Societies, Princeton: Princeton University Press.

Frye T. (2002a) Capture or Exchange? Business Lobbying in Russia. Europe-Asia Studies, vol. 54, no 7, pp. 1017-1036.

Frye T. (2002b) Private Protection in Russia and Poland. American Journal of Political Science, vol. 46, no 3, pp. 572-584.

Frye T. (2004) Credible Commitment and Property Rights: Evidence from Russia. The American Political Science Review, vol. 98, no 3, pp. 453-466.

Frye T., Yakovlev A., Yasin Y. (2009) The other Russian Economy: How Everyday Firms View the Rules of the Game in Russia. Social Research, vol. 76, no 1, pp. 29-54.

Furubotn E., Rihter R. (2005) Instituty i ekonomicheskaya teoriya: Dostizheniya novoy institutsional'noy ekonomicheskoy teorii [Institutions and Economic Theory: A Contribution of the New Institutional Economics], Saint-Petersburg: Izdatel'skiy dom SPbGU (in Russian).

Galindabaeva V. I. (2014) Megasobytiya v postsovetskikh gorodakh: neopatrimonial'nye mashiny rosta i prisvoenie gosudarstvennoy sobstvennosti [Mega-events in Postsoviet Cities: Neopatrimonial Growth Machines and State Property Appropriation]. Zhurnal sotsiologii i sotsial 'noy antropologii, no 1, pp. 126-140 (in Russian).

Gambetta D. (1993) Reket kak nelegal'nyy pravookhranitel'nyy biznes [Racket as Illegal Protection Business]. Zhurnal "Ekonomicheskaya teoriya prestupleniy i nakazaniy", no 1. Available at: http://corruption. rsuh.ru/magazine/1/n1-09.shtml (accessed 12 February 2016) (in Russian).

Hall B. (2003) Business Method Patents, Innovation and Policy. Working Paper No 9717, Cambridge, MA: National Bureau of Economic Research.

Hamfri K. (2010) Postsovetskie transformatsii v Aziatskoy chasti Rossii [Post-Soviet Transformation in Asian Part of Russia], Moscow: Natalis (in Russian).

Healy K. (2000) Sacred Markets and Secular Ritual in the Organ Transplant Industry. American Journal of Sociology of the Economy, no 105, pp. 1633-1657. 
Hellman S., Geraint J., Kaufmann D. (2000) Seize the State, Seize the Day: An Empirical Analysis of State Capture and Corruption in Transition Economies. Research Working Paper No 2444, Washington, DC: World Bank.

Hendley K., Murrell P., Ryterman R. (2000) Law, Relationships and Private Enforcement: Transactional Strategies of Russian Enterprises. Europe-Asia Studies, vol. 52, no 4, pp. 627-656.

Hesse C. (2002) The Rise of Intellectual Property, 700 B.C. - A.D. 2000: An Idea in the Balance. Doedalus, no 131, Spring, pp. 228-251.

Jacobs A. (2005) A Matter of Trust: Cognition, Institutions and the Sources of Credible Commitment. Research Working Paper. Available at: http://faculty.arts.ubc.ca/jacobs (accessed 12 February 2016).

Kapelyushnikov R. I. (2004) Pravo sobstvennosti (ocherk sovremennoy teorii) [Property Rights: Modern Theories]. Otechestvennye zapiski, no 6. Available at: http://www.strana-oz.ru/2004/6/pravo-sobstvennosti-ocherk-sovremennoy-teorii (accessed 12 February 2016) (in Russian).

Karbainov N. I. (2012) Izyatie neformal'noy sobstvennosti v Rossii: negativnye uroki podgotovki k Olimpiyskim igram v Sochi [Confiscation of Informal Property in Russia: Negative Lessons of the Preparation for the Olympic Games in Sochi]. Seriya "Analiticheskie zapiski po problemam pravoprimeneniya”. SaintPetersburg: IPP EUSPb (in Russian).

Kasatkina A. K. (2015) Chastnaya sobstvennost' i kollektivnoe tovarishchestvo. Rezhimy sobstvennosti i sotsial'nye otnosheniya $\mathrm{v}$ sadovodcheskikh nekommercheskikh tovarishchestvakh Leningradskoy oblasti 2000-kh godov [Private Property and Collective "Comradeship": Property Regimes and Social Relationships in Garden Non-Profit Associations ("Comradeships"), Leningrad Region, the Early 2000s]. Zhurnal sotsiologii i sotsial'noy antropologii, no 1, pp. 163-178 (in Russian).

Keister L., Moller S. (2000) Wealth Inequality in the United States. Annual Reviews Sociology, no 26, pp. 63-81.

Kordonskiy S. G. (2008) Soslovnaya struktura postsovetskoy Rossii [The Structure of Soslovia in Post-soviet Russia], Moscow: Institut Fonda "Obshhestvennoe mnenie" (in Russian).

Latov Y. V. (2003) "Ekonomika reketa” v postsovetskoy Rossii ["Economics of Racket" in Postsoviet Russia], Internet-konferenciya "Poisk effektivnykh institutov dl'a Rossii XXI veka”. Available at: http://ecsocman. hse.ru/text/16214862/ (accessed 12 February 2016) (in Russian).

Levin S. N., Kurbatova M. V. (2011) Setevye vzaimosvyazi rossiyskogo biznesa: delovaya korruptsiya i organicheskiy institut real'noy modeli institutsional'noy organizatsii rossiyskoy ekonomiki [Network Interactions of Russian Business: Business Corruption and Organic Institution of the Real Institutional Organization Model of the Russian Economy]. Zhurnal institutsional 'nykh issledovaniy, vol. 3, no 2, pp. 50-69 (in Russian).

Levin S. N., Kagan E. S., Kislitsyn D. V. (2014) Internalizovannyy politichesky resurs krupnogo biznesa v Kuzbasse [Internalized Political Resources of Large Business in Kuzbass]. EKO, no 1, pp. 85-94 (in Russian).

Marx K. (2003) Kapital. Kritika politicheskoy ekonomii, vol. 1 [Capital: Critics of Political Economy, vol. 1], Moscow: Eksmo (in Russian). 
McEvoy A. (1998) Markets and Ethics in U.S. Property Law. Who Owns America? Social Conflict over Property Rights (ed. M. Jacobs), Madison: University Wisconsin Press, pp. 94-113.

Milgrom P., Greif A., Weingast B. (1994) Coordination, Commitment, Enforcement: the Case of the Merchant Guild. The Journal of Political Economy, vol. 102, no 4, pp. 745-766.

Moe T. (1984) The New Economics of Organization. American Journal of Political Science, vol. 28, no 4, pp. 739-777.

North D. (1993) Institutions and Credible Commitment. Journal of Institutional and Theoretical Economics, vol. 149, no 1, pp. 11-23.

North D. (1997) Instituty, institutsional'nye izmeneniya i funktsionirovanie ekonomiki [Institutions, Institutional Change and Economic Performance], Moscow: Nachala (in Russian).

North D., Weingast B. (1996) Constitutions and Commitment: the Evolution of Institutions Governing Public Choice in 17th Century England. Empirical Studies in Institutional Change (eds L. Alston, T. Eggertsson, D. North), Cambridge: Cambridge University Press, pp. 134-166.

Nureev R. M., Latov Y. V. (2015) Postsovetskoe institutsional'noe razvitie: v poiskakh vykhoda iz kolei vlastisobstvennosti [Institutional Development in Post-Soviet Russia: in Search for an Escape from the Pathdependence of 'Power-Ownership']. Mir Rossii, vol. 24, no 2, pp. 50-88 (in Russian).

Paneyakh E. L. (2013) Zaregulirovannoe gosudarstvo [An Extra-regulated State]. Pro et Contra, vol. 17, no 1-2, pp. 79-92 (in Russian).

Pecheski R. (2000) Abort i vybor zhenshhiny: gosudarstvo, seksual'nost' i reproduktivnye prava [Abortion and Woman's Choice: the State, Sexuality, and Reproductive Freedom]. Antologiya gendernoy teorii [Anthology on Gender Theory] (ed. E. Gapova, A. Usmanova), Minsk: Propilei, pp. 141-150 (in Russian).

Pliskevich N. M. (2015) Transformatsii sistemy vlasti-sobstvennosti v Rossii: regional'nyy aspekt. Mogut li regiony nachat' svoy put' k modernizatsii [The Transformation of 'Power-Ownership' Relations in Russia: Would Regions Pave the Path towards Modernization?]. Mir Rossii, vol. 24, no 2, pp. 89-104 (in Russian).

Podlas K. (2010) The Moral of the Story... Musical Artists Must Protect their Own Rights in Digital Music. Wake Forest Intellectual Property Law Journal, vol. 10, no 3, pp. 265-288.

Polanyi K. (2002) Velikaya transformatsiya: politicheskie i ekonomicheskie istoki nashego vremeni [The Great Transformation: the Political and Economic Origins of Our Time], Moscow: Aleteya (in Russian).

Portes A. (2003) Neformal'naya ekonomika i ee paradoksy [Informal Economy and Its Paradoxes]. Journal of Economic Sociology = Ekonomicheskaya sotsiologiya, vol. 4, no 5, pp. 34-53. Available at: https://ecsoc. hse.ru/2003-4-5.html (accessed 12 February 2016) (in Russian).

Rastorguev S. V. (2012) Inkumbenty-biznesmeny v oblastnoy zakonodatel'noy vlasti v CZFO v 2000-2011 godakh [Incumbents from Business in Regional Legislative Bodies in the North-Western Federal Okrug in 2000-2011]. Politicheskie issledovaniya, no 4, pp. 117-125 (in Russian). 
Riker W., Sened I. (1991) A Political Theory of the Origin of Property Rights: Airport Slots. American Journal of Political Science, vol. 35, no 4, pp. 951-969.

Robinson J. (1998) Theories of "Bad Policy”. Journal of Political Reforms, no 1, pp. 1-46.

Roemer J. (1989) What is Exploitation? Philosophy Public Affairs, no 18, pp. 90-97.

Rubin G. (2000) Obmen zhenshhinami: zametki po politekonomii pola [The Traffic of Women: Notes on the Political Economy of Sex]. Antologiya gendernoy teorii [Anthology on Gender Theory] (ed. E. Gapova, A. Usmanova), Minsk: Propilei, pp. 99-117 (in Russian).

Sakaeva M. M. (2012) Parlament kak "okno vozmozhnostey": issledovanie povedeniya predprinimateley s deputatskim mandatom v khode realizatsii rynochnykh interesov [Parliament as a "Window of Opportunities": A Study on the Pursuit of Business Interests by Entrepreneurs with Mandates]. Journal of Economic Sociology = Ekonomicheskaya sotsiologiya, vol. 13, no 3, pp. 96-123. Available at: https://ecsoc.hse. ru/2012-13-3.html (accessed 12 February 2016) (in Russian).

Sakaeva M. M. (2015) Spros predprinimateley na sotsial'nyy kapital v pole rynka i politiki [Entrepreneurial Demand for Social Capital within Market and Politics]. Zhurnal sotsiologii i social'noy antropologii, no 1, pp. 110-122 (in Russian).

Sapov G. (2004) Sobstvennost': usloviya chelovecheskoy deyatel'nosti i yuridicheskaya kategoriya [Property: Conditions of Human Activity and Juridicial Category]. Otechestvennye zapiski, no 6. Available at: http://www.strana-oz.ru/2004/6 (accessed 12 February 2016) (in Russian).

Scheper-Hughes N. (2000) The Global Traffic of Human Organs. Current Anthropology, vol. 41, no 2, pp. 191-224.

Sharp L. (2000) The Commodification of the Body and Its Parts. Annual Reviews Anthropology, no 29, pp. 287-328.

Shleifer A., Vishny R. (1998) The Grabbing Hand: Government Pathologies and Their Cures, Cambridge, MA: MIT Press.

Sobstvennost' klassikov: John Lokk [Property of Classic: John Lokk]. (2004) Otechestvennye zapiski, no 6. Available at: http://www.strana-oz.ru/2004/6 (accessed 12 February 2016) (in Russian).

Solomon P. G., Jr. (2013) Ugolovnoe presledovanie i regulirovanie biznesa: prekrashchenie rossiyskoy isklyuchitel'nosti i kul'tivirovanie verkhovenstva prava [Prosecution and Regulation of Business: Termination of Russian Exceptionalism and Cultivation of the Rule of Law]. Verhovenstvo prava kak faktor ekonomiki [The Rule of Law as Economic Factor] (eds E. V. Novikova, A. G. Fedotov, A. V. Rozencvajg, M. A. Subbotin), Moscow: Liberal'naya missia, pp. 413-430 (in Russian).

Soto E. de (1995) Inoy put'. Nevidimaya revolyutsiya v tret'em mire [The other Path: The Invisible Revolution in the Third World], Moscow: Catallaxy (in Russian).

Stammler F., Wilson E. (2006) Dialog for Development: An Exploration of Relations Between Oil and Gas Companies, Communities and the State. Sibirica, vol. 5, no 2, pp. 1-42. 
Steiner P. (2003) Gifts of Blood and Organs: The Market and "Fictitious" Commodities. Revue Francaise de Sociologie. Supplement: An Annual English Selection, no 44, pp. 147-162.

Swedberg R. (2003) Principles of Economic Sociology. Princeton: Princeton University Press.

Tambovtsev V. L. (ed.) (2009) Prava sobstvennosti, privatizatsiya i natsionalizatsiya v Rossii. [Property Rights, Privatization and Nationalization in Russia], Moscow: Liberal'naya missia (in Russian).

Tulaeva S. A. (2014) Neftyanye kompanii, olenevodcheskie soobshchestva i mestnye organy vlasti: prava na zemlyu s perspektivy raznykh steykkholderov [Oil Companies, Reindeer-Herding Communities and Local Authorities: Rights to Land from the Perspective of Various Stakeholders]. Zhurnal sotsiologii i sotsialnoy antropologii, no 5, pp. 141-157 (in Russian).

Vasil'ev L. S. (2005) Istoriya Vostoka. [The History of the East]. Uchebnik: 2 vols. Vol. 1, Moscow: Vysshaya shkola (in Russian).

Weber M. (2002) Protestantskaya etika i dukh kapitalizma [The Protestant Ethic and the Spirit of Capitalism], Ivano-Frankovsk: East View (in Russian).

Volkov V. (2002) Silovoe predprinimatel'stvo [Violent Entrepreneurship], Saint-Petersburg: Letniy sad (in Russian).

Waldby C., Cooper M. (2006) The Biopolitics of Reproduction: Post-Fordist Biotechnology and Women's Clinical Labour. Working Paper No 15, London: Global Biopolitics Research Group.

Weimer D. (1997) The Political Economy of Property Rights. The Political Economy of Property Rights. Institutional Change and Credibility in the Reforms of Centrally Planned Economics (ed. D. Weimer), Cambridge: Cambridge University Press, pp. 1-20.

Weingast B. (1997) The Political Commitment to Markets and Marketization. The Political Economy of Property Rights. Institutional Change and Credibility in the Reforms of Centrally Planned Economics (ed. D. Weimer), Cambridge: Cambridge University Press, pp. 43-50.

Yakovlev A. A. (2013) Otnyat' ili sozdat'? Stimuly k primeneniyu nasiliya v ekonomike i faktory, sposobnye ego ogranichit' [Take Away or Create? Incentives to Use Violence in the Economy and the Factors That May Limit it]. Verkhovenstvo prava kak faktor ekonomiki [The Rule of Law as Economic Factor] (eds E. V. Novikova, A. G. Fedotov, A. V. Rozencvajg, M. A. Subbotin), Moscow: Liberal'naya missia, pp. 121-143 (in Russian).

Zhuravskaya T. N. (2011) "Sery import" v Blagoveshchenske: chto novogo? ["Shadow Import" in Blagoveshchensk: What is New?]. Journal of Economic Sociology = Ekonomicheskaya sotsiologiya, vol. 12, no 1, pp. 54-71. Available at: https://ecsoc.hse.ru/2011-12-1.html (accessed 12 February 2016) (in Russian).

Received: April 24, 2016.

Citation: Sakaeva M. (2016) Prava sobstvennosti v fokuse sotsiologicheskikh teoriy: cherez razmyvanie granits k mezhdistsiplinarnosti [Property Rights in the Focus of Social Theories: Through Breaking Boundaries towards Interdisciplinary]. Journal of Economic Sociology = Ekonomicheskaya sotsiologiya, vol. 17, no 3, pp. 110-131. Available at: https://ecsoc.hse.ru/2016-17-3.html (in Russian). 


\section{НОВЫЕ КНИГИ}

\section{Е. А. Мельникова \\ Как песни попадают на радио, или Что успех Рианны в чартах значит для исследователя инноваций ${ }^{1}$}

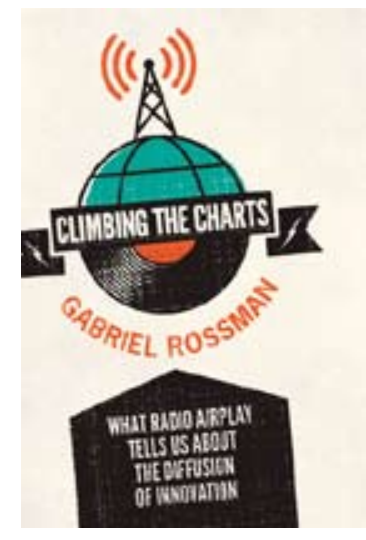

Рецензия на книгу: Rossman G. 2012. Climbing the Charts: What Radio Airplay Tells Us about the Diffusion of Innovation. Princeton, NJ: Princeton University Press. 184 p.

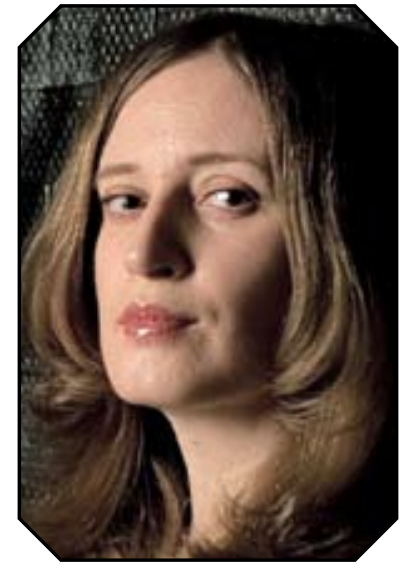

МЕЛЬНИКОВА Елена Александровна магистр социологии, аспирант Института образования Национального исследовательского университета «Высшая школа экономики». Адрес: 101000, Россия, г. Москва, ул. Мясницкая, д. 20.

Email: leni.melnikova@ gmail.com
Рецензия посвящена монографии Габриэля Россмана "Climbing the Charts: What Radio Airplay Tells Us about the Diffusion of Innovation» ("Поднимаясь в чартах: что радиовешание может рассказать нам о диффузии инноваций»), которая вышла в издательстве Princeton University Press в 2012 г. Из названия книги следует, что её автор пытается понять, как песни становятся хитами. При этом распространение музыкальных композиций по радиостанциям рассматривается как частный случай диффузии инноваций. По словам Г. Россмана, он фокусируется не на акторах, которые первыми начинают внедрять инновацию, а на природе явления диффузии инноваций как такового. В частности, его интересует, какие обстоятельства определяют тот или иной механизм распространения песен. Для этого Россман, развивая идеи представителей парадигмы производства культуры, анализирует, как осуществляется взаимодействие между звукозаписывающими компаниями, независимыми радиопромоутерами и радиостанциями, а также исследует внутреннюю среду радиобизнеса. В результате анализа большого массива информации (прежде всего это данные о прочгрывании в радиоэфире более тысячи случайным образом отобранных синглов за 20022007 гг.) Россман создаёт сложную, изобилующую деталями картину американской музыкальной радиоиндустрии, вычленяя две наиболее значимые силь, напрямую влияющие на успешность распространения новых композиичий в радиоэфире. Во-первых, это усилия рекорд-лейблов, направленные на подкуп представителей радиостанций, и, во-вторых, система музыкальных жанров, которая, накладываясь на систему форматов радиостанций, довольно жёстко структурирует поведение программных директоров при принятии или отклонении песен. Соответственно в первой части рецензии анализируется роль неформальных платежей как важнейшей движущзей силь музыкальной радиоиндустрии, а далее рассматривается, какую роль в изучаемом прочессе распространения песен играет их жанровая спе-

Статья подготовлена во время участия в проекте «Школа рецензирования» (№ 16-050031) в рамках Программы «Научный фонд Национального исследовательского университета “Высшая школа экономики”» в 2016 г. и с использованием средств субсидии на государственную поддержку ведущих университетов Российской Федерации в целях повышения их конкурентоспособности среди ведущих мировых научнообразовательных центров, выделенной НИУ ВШЭ. 
цифика. В завершение поднимается вопрос об актуальности исследования Россмана в век развития интернет-коммуникаций.

Ключевые слова: диффузия инноваций; культурное производство; хиты; музыкальное радиовещание; коррупция в музыкальной индустрии; жанры; система классификаций в искусстве.

\section{Введение}

Представитель парадигмы производства культуры Пол Хирш, анализируя, как устроены культурные индустрии, указывает на значимость так называемых привратников (gate-keepers), то есть работающих на массмедиа экспертов, которые играют ключевую роль при принятии решений о коммерческой судьбе того или иного продукта культурной фабрики [Hirsch 1972: 648-649].

Другие классики концепции культурного производства — Ричард Петерсон и Дэвид Бергер, изучая причины сенсационной популярности рок-н-ролла в США 1950-х, отмечают: тот факт, что Элвис Пресли, подписанный небольшим независимым лейблом из Мемфиса, ворвался в 1956 г. на американскую музыкальную сцену, является прежде всего красноречивым свидетельством потери ведущими на тот момент звукозаписывающими компаниями контроля над процессом раскрутки синглов в радиоэфире [Peterson, Berger 1975: 164].

Профессор Калифорнийского университета в Лос-Анджелесе Габриэль Россман пытается понять, какие механизмы стоят за распространением новых песен по радиостанциям и как изучение этих механизмов может расширить наше понимание природы диффузии инноваций. Для этого он, развивая идеи Хирша, Петерсона и Бергера, концентрируется на анализе того, как осуществляется взаимодействие между звукозаписывающими компаниями, независимыми промоутерами (independent radiopromoters - IRPs, или просто indies) и радиостанциями, а также исследует внутреннюю среду радиоиндустрии.

Россман начинает свой анализ с рассмотрения того, какой была дорога в радиоэфир композиций певицы Рианны из её очень успешного с коммерческой точки зрения альбома «Good Girl Gone Bad» («Xорошая девочка отбилась от рук»). Исследователь отмечает, что первый сингл «Umbrella» («Зонтик») практически моментально завоевал эфир радиостанций, однако по прошествии какого-то времени процесс распространения данной композиции ощутимо замедлился. Это, по мнению Россмана, сигнализирует о том, что успех сингла на радио был обусловлен прежде всего воздействием неких внешних сил (другими словами, в данном случае мы можем говорить об экзогенной модели диффузии инноваций²). При этом другие синглы из «Good Girl Gone Bad», стартовавшие на радио, как и «Umbrella», вскоре после выхода альбома, не всегда распространялись в соответствии с тем же графиком. Таким образом, экспансию трека «Umbrella» нельзя объяснить, казалось бы, лежащим на поверхности обстоятельством,

2 Противоположностью экзогенной модели диффузии инноваций является описанная Эвереттом Роджерсом эндогенная модель, предполагающая невысокую скорость распространения нововведений на этапе их внедрения, когда новшеством охвачена лишь небольшая группа потребителей-новаторов. Однако в дальнейшем, по мере приобщения к инновации других групп потребителей (ранних последователей и раннего большинства) темп проникновения нововведения возрастает. При этом на последующем этапе, когда подключаются позднее большинство и опоздавшие, скорость распространения инновации вновь снижается [Rogers 2003]. Таким образом, эндогенная модель диффузии инноваций графически может быть описана с помощью S-кривой (медленный старт, стремительный рост и последующее снижение скорости проникновения), в то время как экзогенной модели соответствует кривая, с самого начала описывающая стремительный рост, который впоследствии сменяется замедлением скорости адаптации инновации. В первом случае драйвером распространения инновации оказывается механизм «заражения», или имитации, благодаря которому нововведение постепенно охватывает не только узкий круг новаторов, но и большинство; во втором случае диффузия инновации осуществляется прежде всего путём давления, навязывания извне. 
что радиостанции просто стремятся как можно быстрее вывести в эфир композиции из новых альбомов.

Что же в этом случае координирует действия программных директоров радиостанций? Что это за внешняя сила, которая, выводя одни песни в лидеры национальных чартов, оставляет другие композиции за пределами хит-парадов? В поисках ответа на эти вопросы Россман, словно первоклассный детектив, вдумчиво и придирчиво изучает профиль одного «подозреваемого» за другим.

Подозрение в первую очередь падает на централизованное программирование эфира на радиостанциях, относящихся к одним и тем же крупным радиоконгломератам: «Представьте себе мощную сеть радиостанций типа Clear Channel Communication, которая, вместо того чтобы развивать сеть региональных программных директоров, имеет лишь одного такого директора в центральном офисе в СанФранциско. Он-то и создаёт плейлист для всех станций компании» (р. 12). В этом случае распространение нового сингла в рамках каждой сети происходит скачкообразно: ещё вчера ни одна радиостанция не проигрывала сингл, а сегодня он уже включён в плейлист каждой из них.

Однако предпринятый автором анализ того, как осуществлялось распространение композиции «Umbrella» в рамках каждой из крупных сетей, включая Clear Channel Communication, позволил опровергнуть выдвинутую гипотезу. Было показано, что, хотя синглы и распространяются в радиоэфире под влиянием некоей внешней силы, она не может быть сведена к некоему всемогущему центральному программному директору. Таким образом, централизованное программирование выведено из круга подозреваемых.

Вместе с тем Россману удалось доказать значимость таких факторов, как агрессивное, нередко предполагающее дачу взяток продвижение исполнителя рекорд-компанией, а также жанр музыкальной композиции - прежде всего то, насколько он вписан в существующую сетку жанров. Соответственно эти два на первый взгляд не связанных друг с другом вопроса — агрессивный маркетинг и коррупция в музыкальной индустрии, а также жанровые конвенции в мире популярной музыки - оказываются ключевыми для Россмана.

Монография состоит из семи глав. Глава 1 является вводной. В главе 2 книги демонстрируется, что распространение песен в радиоэфире носит экзогенный характер. Далее, на протяжении глав 3--6, автор подробно рассматривает те ключевые силы, которые ответственны за подобный механизм диффузии. В главе 7 подводятся итоги исследования, а также предпринимается попытка анализа того, какие изменения претерпевает музыкальная индустрия в условиях, когда Интернет уверенно вытесняет радио с позиции одного из ключевых медиумов.

Главным источником эмпирических данных для Россмана стал сервис Mediabase, в котором в автоматическом режиме фиксируются синглы, звучащие в эфире американских и канадских радиостанций. На основе данных Mediabase автор сформировал выборку из 1137 синглов, изданных в течение 2002-2007 гг. Кроме того, в ходе работы Россман активно использовал документы, свидетельствующие о взятках в музыкальной индустрии 2000-х гг. (соответствующая база данных доступна на сайте генерального прокурора Нью-Йорка). Ещё один задействованный автором источник информации данные реализованного им опроса программных директоров 123 североамериканских радиостанций. Наконец, в целях иллюстрации некоторых своих идей Россман привлёк ряд кейсов (один из них, связанный со взлётом и падением кантри-группы Dixie Chicks, будет рассмотрен ниже). Среди использованных методов анализа данных можно назвать прежде всего регрессионный (см. главы 2 и 5), а также сетевой анализ (см. главу 4). 


\section{«Война» за эфир, или Роль взяток в продвижении синглов}

Предпринятый автором монографии экскурс в историю скандалов в связи со взятками в американской музыкальной индустрии (р. 25-35) позволяет заключить, что, невзирая на все попытки законодательного регулирования, такого рода скандалы возникают вновь и вновь, причём с завидной периодичностью (примерно каждые 15 лет). Более того, проведённый в 2008 г. опрос рекорд-лейблов свидетельствует о том, что серая зона в музыкальном бизнесе по-прежнему существует, и взятки, встречаясь гораздо реже, чем в 1950-1990 гг, тем не менее всё ещё играют значительную роль в индустрии звукозаписи (p. 35).

Как утверждает Россман, чаще всего дача взятки осуществляется через упомянутых выше независимых радиопромоутеров - консультантов, помогающих протеже рекорд-лейблов попасть в радиоэфир (p. 24). Впрочем, этим их роль, конечно, не исчерпывается; они оказывают и легальную помощь, которая особенно востребована, когда речь идёт о небольших лейблах, не способных взять на себя весь цикл работ, связанных с продвижением исполнителя.

Россман полагает, что музыкальная индустрия ходит кругами: поначалу взятка («payola») — это то, что лейбл использует как убедительный аргумент в войне за радиоэфир, однако когда число вовлечённых в это звукозаписывающих компаний превышает какой-то порог, взятка превращается в некий предполагаемый по умолчанию элемент взаимодействия лейбла и радиостанции. Со временем размер взятки становится столь высоким, что львиная доля доходов рекорд-индустрии уходит именно радиобизнесу. Такая ситуация подталкивает игроков рынка звукозаписывающей индустрии к попыткам самоорганизации и коллективным действиям. В итоге принимаются меры, временно подавляющие взяточничество и подталкивающие систему к кризису, а следовательно, к перезагрузке.

Таким образом, взятка в музыкальной индустрии предстаёт подкупом, инициируемым лейблами, но быстро превращается в вымогательство со стороны радио. Если поначалу взятка может поставить одну из компаний в привилегированное положение, то впоследствии, став явлением универсальным и широко распространённым, не даёт никаких бонусов, поскольку платят уже все рекорд-компании. По сути, мы имеем дело с хорошо знакомой «дилеммой заключённого», то есть оптимальная ситуация (полный отказ от взяток) в данном случае недостижима в силу невозможности скоординировать действия всех участников рынка звукозаписи.

Впрочем, система взяток в музыкальной индустрии 2000-х гг. гораздо более неочевидная и, так сказать, изысканная, чем аналогичная система, функционировавшая до конца 1980-х гг. Она начала формироваться в результате бойкота в 1986 г. ведущими американскими рекорд-лейблами радиопромоутеров из картеля Network, ассоциированных с Cosa Nostra, в частности, с семьёй Гамбино, одной из тех, кто по настоящее время контролирует преступную деятельность в США. В итоге места гангстеров в креслах музыкальных консультантов заняли профессиональные и респектабельные люди. Следствием вытеснения из индустрии криминализированных промоутеров стало то, что на смену явно декларируемому принципу quid pro quo 4 пришёл своего рода дарообмен. Так, если во времена господства Network речь шла о деньгах в конверте, то сегодня рекорд-лейблы и промоутеры дарят радиостанциям или отдельным их представителям подарки - например, пригласительные на концерты, футболки с автографами

3 Отметим, что, используя понятие «взятка» (payola), Россман описывает большое семейство разнокачественных практик - от неофициальных платежей и подарков радиостанциям (таким подарком может быть, например, концерт популярной группы, сыгранный непосредственно на станции) до подарков сотрудникам этих радиостанций и денежных выплат им (р. 23-24).

4 То за это (лат.) — фразеологизм, обычно используемый в значении «услуга за услугу». — Примеч. ред. 
звёзд или даже билеты на Гавайи [Ahlkvist, Faulkner 2002: 202]. При этом, анализируя документы, которые стали доступны широкой публике в итоге последнего коррупционного скандала в музыкальной индустрии (2005 г.), Россман отмечает, что переписка между представителями лейблов либо промоутерами и сотрудниками радиостанций зачастую выглядит как эпистолярий старых товарищей, которые, помогая друг другу, словно бы и не рассчитывают на награду и в силу этого не обговаривают условия её получения.

К сожалению, в монографии Россман не развил эту линию анализа, но он, безусловно, оценил её потенциал. Так, в одном своём интервью, опубликованном вскоре после выхода книги, он отмечает: «Я нахожу это невероятно интересным, поскольку это что-то из антропологии дарообмена, но реализованное профессиональными бизнесменами» [McArdle 2013]. Более того, в своей более поздней работе (2014 г.) исследователь подробно рассматривает феномен подобного «постыдного (даро)обмена» [Rossman 2014], полагая, что на содержательном уровне он представляет собой не что иное, как нарушение границы между сакральным и профанным, в результате чего актуализируется описанная Мэри Дуглас проблема загрязнённого, скверного сакрального [Douglas 1966]. Подобные неявные взятки в музыкальной индустрии 2000-х гг., по Россману, - классический пример такого рода инициирующего трансгрессию обмена (наряду с проституцией или, к примеру, сравнительно невинным университетским преподавателем, угощающим студентов печеньем перед раздачей им бланков с вопросами о качестве своей работы) [Rossman 2014: 45].

\section{Система жанров}

В главе 5 монографии Россмана разбирается интересный кейс - история взлёта и падения техасской кантри-группы Dixie Chicks. «Ещё в начале марта 2003 г. Dixie Chicks были, возможно, самой популярной группой в Америке», - отмечает автор (р. 59). Однако всего через несколько дней ситуация кардинально изменилась, и причиной стало то, что 10 марта, выступая в лондонском клубе, вокалист группы Натали Мэнс обратилась к аудитории со словами осуждения войны в Ираке, сказав, помимо прочего, следующее: «Мы стыдимся того, что президентом США является техасец» (р. 59). После того как это заявление разошлось по СМИ, радиостанции стали отказываться от включения песен группы в свои плейлисты. И последовавшие вскоре извинения Мэнс не изменили ситуацию. Спустя несколько недель после инцидента доля радиоэфира Dixie Chicks составила лишь пятую часть от того, что было до 10 марта. Кроме того, группа потеряла первые места в чартах.

Анализируя историю распространения в сети постов о проступке Dixie Chicks, Россман делает вывод о том, что занесение группы в стоп-листы было во многом инициировано консервативными социальными движениями, которые, самоорганизовавшись, атаковали радиостанции звонками и сообщениями. В связи с этим симптоматично, что раньше других Dixie Chicks были заблокированы радиостанциями из республиканских «красных» штатов.

Кроме того, дело тут ещё, очевидно, и в самом жанре кантри: это музыка, всегда ассоциировавшаяся с белой консервативной сельской Америкой и её ценностями, которые наряду с религиозностью неизменно подразумевали и патриотизм. Другими словами, кантри-музыкант, публично выражающий «антиамериканскую» точку зрения, - это самый настоящий предатель, и реакция фанатов на него соответствующая.

Впрочем, в контексте данного исследования гораздо более значимым представляется не взаимосвязь низовой инициативы музыкальных фанов и жанровых конвенций, а то, каким образом существующая система жанров регулирует поведение продюсеров радиостанций. Для ответа на этот вопрос Россман обращается к идеям Пола Димаджио, изложенным в его классической статье «Classification in Art» 
(«Классификации в искусстве») [DiMaggio 1987]. Димаджио исходит из тезиса о том, что жанры в их совокупности образуют систему классификаций, которые делают возможной рецепцию того или иного культурного продукта (как конечными потребителями, так и независимыми промоутерами и радиостанциями). Соответственно жанровая чистота той или иной музыкальной композиции оказывается значимым фактором, во многом определяющим ее успех или провал. Иначе говоря, сингл с безусловной жанровой принадлежностью быстро попадает в ротацию радиостанции, формат которой подходит данному жанру (то есть, используя терминологию Россмана, инновация быстро адаптируется (р. 76); на макроуровне этому процессу соответствует экзогенный паттерн диффузии инноваций). В противном случае радиостанция, как правило, не будет торопиться включать трек в свой плейлист до тех пор, пока это не сделает хотя бы часть станций сходного формата (в этом случае можно будет говорить уже об эндогенном процессе распространения музыкальной композиции).

Итак, жанры, лежащие в основе системы классификаций, структурируют поведение «стражников» от массмедиа, связанное с принятием или отклонением синглов, то есть инноваций. Как только та или иная жанровая категория становится общепринятой, распространение песен, соответствующих конвенциям этого жанра, начинает осуществляться быстрее и может быть описано с привлечением экзогенной модели диффузии инноваций. Однако же сам процесс институционализации, формирования категории предполагает неопределённость и имитацию одними радиостанциями других.

\section{Актуально ли изучение радио в век Интернета?}

Гуру альтернативного рока Игги Поп, выступая на радиостанции BBC 6 Music, долго перечислял недостатки современного музыкального радиовещания, а потом оборвал себя и заметил: «Вообще, теперь, когда есть Интернет, люди могут выбирать, какую музыку они хотят слушать, и самостоятельно изучать её. Скажем, если они вдруг захотят посмотреть на меня, прыгающего на арене Manchester Apollo с лошадиным хвостом < ... Что ж, пусть смотрят» [ВВС 2014].

В самом деле, зачем изучать радиоиндустрию в XXI веке, когда в распространении музыки все большую роль играет Интернет - будь то файлообменник Napster, видеосервис YouTube или музыкальный интернет-каталог и социальная сеть last.fm?

Габриэль Россман по этому поводу отвечает примерно так: даже в случае, если самые смелые прогнозы относительно роли Интернета в распространении музыки сбудутся, большинство потребителей музыки всегда будут поддерживать интерес к массовой культуре, что подразумевает сохранение влияния ведущих рекорд-лейблов и радиостанций (р. 116). По-прежнему будет актуальной в будущем, по мнению Россмана, и проблема нечестного поведения культурных дистрибьюторов, но, по-видимому, на смену прямому подкупу представителей радиостанций придет мошенничество с привлечением компьютерных алгоритмов (р. 111-112). Таким образом, если исходить из того, что в среде современных исследователей массовой культуры сосуществуют киберреволюционеры, киберскептики и киберэволюционисты [Klinenberg, Benzecry 2005: 14], то Россман, безусловно, относится к этим последним. Он охотно соглашается с тем, что новые технологии влияют на культурные индустрии, но вместе с тем отмечает, что верно и обратное: глубоко укоренённые практики, присущие, например, звукозаписывающей индустрии, также во многом определяют то, как именно новые технологии будут функционировать в соответствующем поле культурного производства. А это значит, что в каком-то смысле результаты его исследования никогда не потеряют актуальности.

В последние годы появляется всё больше исследований, ориентированных на изучение того, как сеть изменяет принципы распространения музыки или как доступность Интернета способствует росту популярности того или иного музыкального жанра. Например, А. Майер и Дж. Тимберлейк анализируют, 
как изначально маргинальный метал (metal) широко распространился по миру, и указывают на то, что Интернет был важным фактором этого успеха [Mayer, Timberlake 2014]. Впрочем, авторы исследования также отмечают, что ключевую роль в этом процессе сыграл все же энтузиазм фанатов и самих музыкальных групп, и Интернет стал не причиной, а лишь мощным катализатором процессов распространения метал-музыки, уже происходивших ранее, в досетевую эпоху [Mayer, Timberlake 2014: 34]. Так что Майер и Тимберлейк, пожалуй, на одной стороне с киберэволюционистом Россманом. Более того, их данные свидетельствуют в пользу тезиса Россмана о том, что при несформированности, неукоренённости музыкального жанра на первое место выходит эндогенный паттерн распространения синглов.

Таким образом, разработанный Россманом категориальный аппарат может быть с успехом задействован при анализе механизмов распространения песен и жанров в мире, где властвуют музыкальные интернет-сервисы.

\section{Заключение}

В специальном номере журнала «Роetics», посвящённом пионеру американской социологии культуры Ричарду Петерсону, опубликована наряду с прочими работами статья самого Петерсона. В ней он пишет, что, оглядываясь назад, склонен считать, что на работу его мотивировало прежде всего стремление «демистифицировать культуру» [Peterson 2000: 231]. И перечисляет множество «широко известных фактов» о культурных индустриях, которые, по результатам реализованных им исследований, оказались не более чем мифами. К примеру, он опровергает представление о роке как о некоем искусственном, не укоренённом в культуре жанре, который навязан слушателям музыкальными радиостанциями. Петерсон показывает, что оценка и интерпретация рок-музыки, как и в случае с джазом или классикой, должна осуществляться на основе изучения её традиций [Peterson 2000: 232].

Не будет преувеличением сказать, что Габриэль Россман проделывает ту же работу в отношении музыкальной индустрии. Опираясь на богатый эмпирический материал, он убедительно разоблачает мифы: нет, говорит он, централизованное программирование не является той скрытой силой, что унифицирует эфир современного хитового радио; нет, прореспубликанские радиоконгломераты не были главными инициаторами радиобойкота Dixie Chicks; нет, радиостанции, как правило, не ориентируются друг на друга, когда свежеизданный сингл штурмует радиоэфир, то есть «эффект заражения» в данном случае не наблюдается.

Впрочем, очевидно, что Россман не ограничивается разоблачениями. Он формулирует и позитивную программу, демонстрируя, что, когда речь идёт о музыкальной композиции устоявшегося, конвенционального жанра, на первый план выходит экзогенная модель распространения, ключевую роль в которой играют агрессивный маркетинг рекорд-лейблов и место данного жанра в сложившейся системе классификаций. Если же речь идёт о синглах, определить жанровую принадлежность которых сложно в силу пограничности или несформированности соответствующего жанра, на первый план выходит эндогенный механизм распространения.

Убедительность выводов Россмана самым тесным образом связана со спецификой его исследовательского объекта - музыкального радиовещания, для которого характерно необычайно быстрое распространение невероятно большого числа песен; при этом важно, что данный процесс чётко фиксируется, то есть, как отмечает сам автор, «синглы на радио для социолога - примерно то же самое, что дрозофила для генетиков» (р. 6). Такое поле открывает большие возможности для исследователя, и Россман сумел предоставленными возможностями воспользоваться. 
Тем не менее нельзя не отметить явную теоретическую эклектичность воззрений автора, а также порой кажущуюся чрезмерной широту охватываемого им предметного поля. В частности, в своей монографии Россман задействует ресурсы социологии искусства, социологии организаций, когнитивной социологии, социологии общественных движений, экономической социологии и ряда других областей социологического - и не только - знания. Впрочем, одним из результатов подобной «неразборчивости» является то, что работа Россмана может быть интересна широкому кругу исследователей, будь то изучающие феномен коррупции криминологи, анализирующие трансформацию системы музыкальных жанров представители исследований культуры (cultural studies), либо развивающие культурноисторический подход в экономической социологии последователи Вивианы Зелизер.

\section{Литература}

Ahlkvist J. A., Faulkner R. 2002. «Will this Record Work for Us?»: Managing Music Formats in Commercial Radio. Qualitative Sociology. 25: 189-216.

BBC. 2014. Music John Peel Lecture - Iggy Pop’s Keynote Speech Transcript. URL: http://www.bbc.co.uk/ programmes/articles/1DBxXYBDJLt2xZgxjzCkLRg/bbc-music-john-peel-lecture-iggy-pops-keynotespeech-transcript

DiMaggio P. 1987. Classification in Art. American Sociological Review. 52: 440-455.

Douglas M. 1966. Purity and Danger: An Analysis of Concepts of Pollution and Taboo. London: Routledge.

Hirsch P. M. 1972. Processing Fads and Fashions: An Organization-Set Analysis of Cultural Industry Systems. American Journal of Sociology. 77: 639-659.

Klinenberg E., Benzecry C. 2005. Cultural Production in a Digital Age. The ANNALS of the American Academy of Political and Social Science. 597: 6-18.

Mayer A., Timberlake J. M. 2014. «The Fist in the Face of God»: Heavy Metal Music and Decentralized Cultural Diffusion. Sociological Perspectives. 57: 27-51.

McArdle M. 2013. Of Music, Payola and Disclosure. An Interview with Gabriel Rossman. URL: http://www. bloombergview.com/articles/2013-07-29/of-music-payola-and-disclosure

Peterson R. A. 2000. Two Ways Culture is Produced. Poetics. 28: 225-233.

Peterson R. A., Berger D. G. 1975. Cycles in Symbol Production: The Case of Popular Music. American Sociological Review. 40: 158-173.

Rogers E. M. 2003. Diffusion of Innovations. New York: Free Press.

Rossman G. 2014. Obfuscatory Relational Work and Disreputable Exchange. Sociological Theory. 32: 43-63. 


\section{NEW BOOKS}

\section{Elena Melnikova}

\section{How Songs Get on the Radio, or What does Rihanna's Chart Success Mean for the Researcher of Innovations}

Book Review: Rossman G. (2012) Climbing the Charts: What Radio Airplay Tells Us about the Diffusion of Innovation, Princeton, NJ: Princeton University Press. 184 p.

MELNIKOVA, Elena - MA in Sociology; PhD Student, Institute of Education, National Research University Higher School of Economics. Address: 20 Myasnitskaya str., Moscow, 101000, Russian Federation.

Email: leni.melnikova@gmail. com this flow process - a channel from distributors (record labels) to surrogate consumers (radio stations). The result of his analysis is a detailed picture of the radio industry which shows us two main external forces driving airplay. The first one is corruption in music industry. The second force is a system of music genre classifications which regulates the process of evaluation of new songs by programming directors of the radio stations. Rossman's findings are based on rich quantitative and qualitative data, first of all, on the cumulative airplay of more than a thousand randomly selected singles released between 2002 and 2007.

Keywords: diffusion of innovations; cultural production; hits; music broadcasting; payola in the music industry; genres; system of classification in art.

\section{Acknowledgements}

The article was prepared within the framework of the Academic Fund Program at the National Research University Higher School of Economics (HSE) in 2016 (grant № 16-05-0031, "School of the Book Review") and supported within the framework of a subsidy granted to the HSE by the Government of the Russian Federation for the implementation of the Global Competitiveness Program.

\section{References}

Ahlkvist J. A., Faulkner R. (2002) "Will This Record Work for Us?”: Managing Music Formats in Commercial Radio. Qualitative Sociology, vol. 25, no 2, pp. 189-216.

BBC (2014) Music John Peel Lecture - Iggy Pop's Keynote Speech Transcript. Available at: http://www. bbc.co.uk/programmes/articles/1DBxXYBDJLt2xZgxjzCkLRg/bbc-music-john-peel-lecture-iggy-popskeynote-speech-transcript (accessed 28 April 2016). 
DiMaggio P. (1987) Classification in Art. American Sociological Review, vol. 52, no 4, pp. 440-455.

Douglas M. (1966) Purity and Danger: An Analysis of Concepts of Pollution and Taboo, London: Routledge.

Hirsch P. M. (1972) Processing Fads and Fashions: An Organization-Set Analysis of Cultural Industry Systems. American Journal of Sociology, vol. 77, no 4, pp. 639-659.

Klinenberg E., Benzecry C. (2005) Cultural Production in a Digital Age. The ANNALS of the American Academy of Political and Social Science, vol. 597, no 1, pp. 6-18.

Mayer A., Timberlake J. M. (2014) "The Fist in the Face of God": Heavy Metal Music and Decentralized Cultural Diffusion. Sociological Perspectives, vol. 57, no 1, pp. 27-51.

McArdle M. (2013) OfMusic, Payola and Disclosure. An Interview with Gabriel Rossman. Available at: http:// www.bloombergview.com/articles/2013-07-29/of-music-payola-and-disclosure (accessed 28 April 2016).

Peterson R. A. (2000) Two Ways Culture is Produced. Poetics, vol. 28, no 2-3, pp. 225-233.

Peterson R. A., Berger D. G. (1975) Cycles in Symbol Production: The Case of Popular Music. American Sociological Review, vol. 40, no 2, pp. 158-173.

Rogers E. M. (2003) Diffusion of Innovations, New York: Free Press.

Rossman G. (2014) Obfuscatory Relational Work and Disreputable Exchange. Sociological Theory, vol. 32, no 1 , pp. 43-63.

Received: April 23, 2016.

Citation: Melnikova E. (2016) Kak pesni popadayut na radio, ili Chto uspekh Rihanna v chartakh znachit dlya issledovatelya innovatsiy [How Songs Get on the Radio, or What does Rihanna's Chart Success Mean for the Researcher of Innovations. Book Review on Rossman G. 2012. Climbing the Charts: What Radio Airplay Tells Us about the Diffusion of Innovation. Princeton, NJ: Princeton University Press]. Journal of Economic Sociology = Ekonomicheskaya sotsiologiya, vol. 17, no 3, pp. 132-141. Available at: https://ecsoc. hse.ru/2016-17-3.html (in Russian). 


\section{КОНФЕРЕНЦИИ}

\section{Т. Б. Кусимова}

\section{Образование и социальное неравенство}

\section{XVII Апрельская международная научная конференция по проблемам развития экономики и общества, 19-22 апреля 2016 г., Москва, Россия}

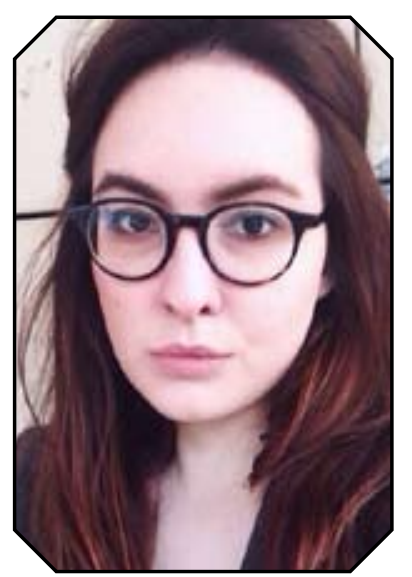

КУСИМОВА Тамара Булатовна студентка бакалаврской программы «Социология» факультета социальных наук, стажёр-исследователь Лаборатории экономикосоциологических исследований Национального исследовательского университета «Высшая школа экономики». Адрес: 101000, Россия, г. Москва, ул. Мясницкая, д. 20.

Email: tkusimova@ yandex.ru
В Высшей школе экономики 19-22 апреля 2016 г. прошла XVII Апрельская международная научная конференция по проблемам развития экономики и общества. В рамках работы конференции был организован симпозиум «Образование и социальная дифференциаиия». Впервые роли образования в воспроизводстве сочиального неравенства была посвящена отдельная секция, в работе которой приняли участие не только учёные из России и стран СНГ, но и эксперты из Великобритании, Китая, США и стран Евpoпы. В ходе докладов и обсуждений были освещены разные аспекты образовательного неравенства - от общих тенденций, выявленных на основе многолетней динамики, до локальных проблем вроде вопросов инклюзивного образования и функиионирования дополнительных секций и кружков для учашихся школ. В целом можно выделить три магистральные темы симпозиума: сравнительные сочиальные исследования эффектов от образования; вопросы адресной соииальной политики по снижению неравенства; исследования неформального образования и направления для дальнейших исследований.

В работе сессий принялиучастиес докладами П. Бьянчи (Университет Феррары, Италия), Л. Гортазар (Всемирный банк), А. Б. Захаров (НИУ ВШЭ, Россия), М. Карной (Стэнфордский университет, США), Н. Н. Кармаева (НИУ ВШЭ, Россия), С. Г. Косареикий (НИУ ВШЭ, Россия), Д. Л. Константиновский (Институт соииологии РАН, Россия), Г. М. Левин (Колумбийский университет, США), Р. Мюрнейн (Гарвардский университет, США), Д. С. Семёнов (НИУ ВШЭ, Россия), А. М. Сидоркин (НИУ ВШЭ, Россия), B. С. Собкин (Российская академия образования, Россия), М. Дж. Фойер (Университет Джорджа Вашингтона, США), И. Д. Фрумин (НИУ ВШЭ, Россия), К. Шафранеи (Университет Николая Коперника, Польща) и др.

Ключевые слова: образование; неравенство; школа; университет; сравнительные исследования; социальная стратификация.

Образование, пожалуй, одна из наиболее популярных областей в современных социальных науках. Может показаться, что не осталось ни одного вопроса, на который исследователи образования не пытались бы найти ответ, - от анализа экономики образования до изучения отдельных педагогических практик. Популярность направления обусловлена постоянным запросом на новые исследования. Во многом это продиктовано тем, насколько сильное влияние образовательные институты оказывают на жизненные траектории людей. Принципиально важное свойство образования 
заключается в том, что в условиях современной «экономики знаний» именно оно напрямую влияет на позиции индивида на рынке труда. Кроме того, образование - это социальный лифт: полученные навыки и диплом статусного вуза становятся инструментом социальной мобильности. Подчёркнутая эгалитарность современного образования позволяет строить достаточно оптимистичные картины: на формальном уровне гендерная и расовая дискриминация остались в прошлом, ликвидация безграмотности стала проблемой исключительно стран третьего мира, а технологический прогресс создаёт как потребность в новых учебных программах, так и места на рынке труда.

Действительно ли всё так безоблачно? Распространено представление о доступном образовании как универсальном благе, способном излечить многие социальные «болезни». Но соответствует ли такое представление действительности? Являются ли современные образовательные системы действующим инструментом социальной мобильности? Какие факторы способны ограничить доступ к образованию? Эти вопросы были освещены в рамках секции «Роль образования в воспроизводстве и уменьшении социального неравенства», организованной в рамках XVII Апрельской международной научной конференции по проблемам развития экономики и общества. В целом можно выделить четыре магистральные темы дискуссий: (1) сравнительные социальные исследования эффектов от образования; (2) вопросы адресной социальной политики по снижению неравного доступа к обучению; (3) исследования неформального образования и (4) направления для дальнейших исследований образования

\section{Глобальный контекст: сравнительные исследования}

Прежде чем обратиться непосредственно к вопросам обучения и социальной мобильности, слушателям конференции была предоставлена возможность взглянуть на проблему в ином ракурсе: действительно ли распространение и повышение качества образования снижает показатель неравенства доходов? С докладом, посвящённым этому вопросу, выступил почётный гость конференции, профессор экономики образования Стэнфордского университета Мартин Карной (см. подробнее: [Carnoy et al. 2012]). Действительно, представление о том, что расширение образовательных возможностей снижает разрыв между самыми богатыми и самыми бедными слоями населения, не только распространено среди исследователей, но отражается и в риторике популярных политиков. Карной ставит под сомнение однозначность этого утверждения, обращаясь к сравнительным исследованиям в развивающихся странах Латинской Америки - в Мексике, Бразилии и Аргентине. Каждое из этих государств сталкивалось с многократным увеличением разрыва между наиболее и наименее обеспеченными слоями населения, и попытки сделать высшее образование доступнее были одной из мер по устранению этого разрыва. При внимательном анализе государственной политики и её последствий отделить эффекты распространения образования от других мер, способствующих снижению неравенства доходов (к примеру, денежные трансферты) оказывается очень сложно. Хотя во всех трёх странах наблюдалось снижение уровня неравенства в доходах, лишь в Бразилии эту ситуацию можно связать с образованием: увеличение предложения квалифицированной рабочей силы «сгладило» распределение зарплат на рынке труда. Что касается Мексики и Аргентины, то там куда больший эффект оказала политика перераспределения доходов (например, в форме пособий или государственных выплат).

Во многом неоднозначность эффектов от образования можно связать с их косвенным влиянием. В отличие от «единовременного» увеличения дохода при получении трансферта, эффекты от образования начинают проявляться только на рынке труда и во многом зависят от его конъюнктуры. Пример тому Аргентина, где высококвалифицированные специалисты с университетскими дипломами долгое время находились на самых выгодных позициях, с огромным отрывом опережая по уровню доходов своих коллег без университетских дипломов. 
Сессию продолжило выступление профессора Ричарда Мюрнейна (Высшая школа педагогических наук, Гарвардский университет). Разрыв между доходами наиболее и наименее квалифицированных и востребованных специалистов воспроизводится не только в переходных, но и в наиболее развитых странах Запада. Очевидным образом это отражается на образовательных возможностях младшего поколения: дети из менее устойчивых в финансовом плане семей имеют меньше шансов поступить в высшее учебное заведение, а значит, и улучшить своё материальное положение, получив хорошо оплачиваемую работу. Проблема доступа к высшему образованию возникает не только на этапе поступления в университет или колледж, но и в течение обучения, которое подразумевает дополнительные временные и денежные затраты, критичные для учащихся из малообеспеченных семей. По данным доклада «Неравенство в образовании в США: тренды, механизмы и источники данных» [Duncan, Murnane 2013], в 1991-1993 гг. лишь 9\% учащихся из низкодоходных групп населения (нижний квартиль) заканчивали четырёхлетний цикл обучения и получали диплом бакалавра, в то время как среди наиболее обеспеченных семей (верхний квартиль) доля выпускников с дипломами составляла больше половины (54\%). Помимо этого, стоит учитывать инертность образовательной траектории «младшая школа университет». По данным исследования, за последние десятилетия сегрегация между «престижными» и другими школами увеличилась. Ситуация напоминает замкнутый круг: в слишком «слабые» школы не идут работать квалифицированные педагоги, а коллектив неособенно заинтересованных учащихся создаёт соответствующее влияние на группу сверстников, снижая результаты выпускных экзаменов и уровень мотивации к дальнейшему обучению. Кроме всего прочего, «выпадение» из системы школьного образования приводит к росту затрат на социальные выплаты и борьбу с преступностью.

\section{Российский контекст: рыночные трансформации и социальная инерция}

Говоря об образовании и неравенстве в России, неизбежно приходится обращаться к специфике посткоммунистических стран: социально-экономические трансформации последних десятилетий коренным образом поменяли конъюнктуру рынка труда, а значит, и запросы, предъявляемые к образованию, и механизмы функционирования образовательных институтов. Произошли ли перемены в социальной структуре, системе стратификации и ценностных ориентациях населения? Российского контекста проблемы касался доклад «Социальное неравенство: от образования к рынку труда», сделанный заведующим отделом социологии образования Института социологии РАН Д. Л. Константиновским. Выступление касалось долгосрочной динамики; были представлены обобщённые результаты исследований, начатых в 1960-х гг. и захватывающих современность.

Согласно докладу, новые экономические реалии предъявляют новые требования к подготовке специалистов. Постепенно университеты удовлетворяют этот запрос. В то же время увеличилось количество молодёжи, поступающей в высшие учебные заведения; во многом это связано с падением рождаемости в 1990-х гг. Такая ситуация привела к разрушению статуса высшего образования: само по себе наличие диплома утратило сигнальную функцию для конкурентных работодателей; ключевую роль стало играть то, в каком университете получен диплом. По словам Константиновского, несмотря на некоторое улучшение ситуации, картина остаётся довольно чёткой: дифференциация университетов увеличивает социальную дифференциацию на рынке труда.

Здесь примечателен ценностный аспект: между образовательными намерениями молодёжи из социальных групп с разным уровнем дохода нет существенных различий - представители всех групп солидарны в своём стремлении получить диплом о высшем образовании. Тем не менее одного желания оказывается недостаточно. Уже на этапе школьного обучения начинает влиять социально-экономический фактор: семьи с более высоким статусом могут позволить себе обучение в лучших школах, с привлечением репетиторов, что существенно облегчает процесс поступления в вуз. По мере понижения социально-экономического статуса семей всё большее число детей заканчивает «слабые» школы, по- 
сле чего идут либо в неэффективные вузы, либо в колледжи и училища, тем самым снижая свой шанс найти высокооплачиваемую работу. Получается, что инертность социальной структуры и устойчивая дифференциация между учебными заведениями могут существенно ограничивать образовательные возможности учащихся независимо от их намерений.

Описанные Д. Константиновским механизмы были более подробно освещены в рамках панельной дискуссии Всемирного банка «Равенство образовательных результатов и приобретаемых навыков».

По словам консультанта Всемирного банка по образовательной политике Лукаса Гортазара, при сравнительно неплохих общих показателях России среди других стран Восточной Европы в Международной программе по оценке образовательных достижений учащихся (Programme for International Student Assessment, PISA), то есть роста уровня общей грамотности, счета, чтения и письма, наблюдается новая тревожная тенденция в российском образовании. Она заключается в росте социальной сегрегации на этапе средней школы, которая «накапливается» со временем и передаётся системе высшего образования, укрепляя уже отмеченную выше дифференциацию среди высших учебных заведений.

Степень социальной сегрегации измерялась с помощью индекса, показывающего вариативность социально-экономических статусов учащихся школ. Чем выше значение индекса, тем более однороден состав учащихся (низкие значения индекса показывают разнородность состава). За 2003-2012 гг. показатели социальной сегрегации выросли от сравнительно невысоких (сопоставимых с Данией и Финляндией) до уровня, превышающего средний показатель по странам - участницам Организации экономического сотрудничества и развития (ОЭСР), характерный для Венгрии и Болгарии. Сложившаяся ситуация имеет негативные последствия в долгосрочной перспективе: учащиеся с низким социальноэкономическим статусом все меньше общаются со своими сверстниками, растущими в более благоприятных условиях. Происходит своеобразная «геттозация» менее благополучных коллективов, что негативно влияет как на образовательные результаты (формирование «слабых» и «сильных» классов и школ), так и на социальную сплочённость.

Какие меры социальной политики способны помочь в борьбе со сложившейся ситуацией? Ряд докладов в рамках симпозиума был посвящён мерам, принимаемым для преодоления сложившегося неравенства. Кроме того, был поднят, возможно, один из наиболее важных для научного сообщества вопросов: как социальные исследования могут влиять на формирование актуальной социальной политики?

\section{Границы применения социальной политики}

Среди решений проблемы растущего неравенства образовательных возможностей - повышение объёма целевых инвестиций в высшее образование. Несмотря на то что эффективность подобных мер неоднократно подвергалась критике, существуют и удачные примеры. С описанием одного из таких случаев выступил профессор экономики и образования Колумбийского университета Генри М. Левин. Актуальный пример: ассоциированная программа ускоренного обучения, организованная в Городском университете Нью-Йорка (City University of New York, CUNY). Основная задача этой программы помочь учащимся муниципальных колледжей (community college) успешно закончить образовательный курс и получить диплом университета Нью-Йорка. В программу входят бесплатные учебники, адаптированное к совмещению с работой расписание занятий, оплата транспортных расходов и тренинги, направленные на повышение учебной мотивации студентов. Оценка эффективности подобной программы проводилась методом оценки издержек (cost-analysis method). Несмотря на то что поддержание подобного учебного плана требует значительно больших бюджетных затрат, чем другие образовательные программы, общая экономическая выгода, по данным Левина, показывает эффективность подобных инвестиций. Выпускники, получившие дипломы, успешнее устраиваются на работу, что увеличивает рост налоговых поступлений и компенсирует бюджетные затраты. 
Возможно ли более широкое применение подобной политики? Какие уроки, извлечённые из американского опыта, делают социальную политику эффективной и способны помочь другим странам? На этот вопрос попытался ответить почётный гость Апрельской конференции, член Американской ассоциации содействия развитию науки и Американской ассоциации исследований в области образования Майкл Дж. Фойер в докладе «От науки к политике: исследования неравенства в США. Свидетельства, динамика, уроки».

Многим знакома ситуация, когда стратегии, разработанные экспертами в области экономики, образования и других социальных наук, отправлялись «под сукно», то есть оставались на стадии проектов, не нашедших практического применения. По мнению Фойера, для более эффективного сотрудничества между государством, проводящим социальную политику, и сообществом исследователей, эта связь должна иметь институциональное оформление. Во-первых, ключевую роль играют профессиональные ассоциации, члены которых понимают специфику исследуемой ими области. Отрасль образовательных исследований чрезвычайно разнообразна: проводятся как количественные опросы, так и полноценные этнографические исследования различных учебных заведений. Для получения валидных и полезных в практике выводов важность исследовательского дизайна оказывается на первом месте. К примеру, в начале 2000-х гг. в США была создана рабочая группа по вопросам научных исследований в образовании (Scientific Research in Education), основной целью которой стало совершенствование методики прикладных исследований. Во-вторых, эффективности взаимодействия государства и исследовательских институтов ощутимо способствует конкурентная ситуация на рынке: исследовательских организаций должно быть как можно больше, чтобы повышать эффективность каждой из них. Кроме того, развитая индустрия прикладных исследований позволяет охватить больший спектр проблем для разработки целевой социальной политики.

\section{Неформальное образование}

Затронутые вопросы по большей части касались «официальных» учреждений — школ и университетов. Подобный фокус оставляет вне внимания исследователей целую отрасль других, не менее важных организаций. Речь идёт о так называемом неформальном образовании. Само определение неформального образования предельно широко, к нему относятся как дистанционные формы получения знаний, или массовые открытые онлайн-курсы (massive open online courses, MOOC), так и дополнительные школьные и дошкольные формы обучения — кружки, секции и факультативные курсы. В рамках симпозиума состоялись круглый стол и серия докладов, посвящённых потенциалу неформального образования как социального лифта и его влиянию на социализацию детей и подростков. В дискуссии приняли участие А. Г. Асмолов (Федеральный институт развития образования, ФИРО), Д. А. Александров (НИУ ВШЭ), К. Аэдо (Всемирный банк), М. Джексон (Стэнфордский университет), Б. В. Куприянов (НИУ ВШЭ), Д. Л. Константиновский (Институт социологии РАН), С. Г. Косарецкий (НИУ ВШЭ), Р. Дж. Мюрнейн (Гарвардский университет), К. Н. Поливанова (НИУ ВШЭ), Я. М. Рощина (НИУ ВШЭ), А. М. Сидоркин (НИУ ВШЭ), В. С. Собкин (Российская академия образования, РАО), Н. В. Тюрина (Международное информационное агентство «Россия сегодня»), И. Д. Фрумин (НИУ ВШЭ)

Неформальное образование в России обладает рядом сущностных характеристик. Во-первых, это его необязательный характер. Всеобщий доступ к дополнительному образованию не закреплён на конституционном уровне, что не позволяет контролировать платный или бесплатный характер обучения, а также стоимость курсов. Тем не менее существенная часть организаций, предоставляющих услуги дополнительного образования, финансируется из муниципального бюджета и остаётся бесплатной для учащихся, что является отличительной чертой России и стран СНГ. Как правило, в США и странах Европы дополнительное образование предоставляется исключительно на платной основе. При этом и на российском рынке дополнительного образования доля платных занятий остаётся значительной, но 
чрезвычайно разнообразной по стоимости - от символических нескольких сотен рублей до нескольких сотен тысяч за образовательный курс.

Может ли дополнительное образование быть вспомогательным фактором социальной мобильности? По данным Мониторинга экономики образования за 2012-2014 гг., далеко не все дети включаются в дополнительное образование до школы, когда оно является преимущественно платным. Это становится причиной неравенства стартовых позиций в пользу семей с более высоким социально-экономическим статусом. Данная ситуация сохраняется и при переходе в школу: дети из семей с высокими потребительскими характеристиками в среднем имеют более продолжительные траектории дополнительного образования вплоть до поступления в вуз. Положение может усугубляться территориальной неравномерностью: наблюдается довольно существенное отставание малых поселений по степени охвата учреждениями дополнительного образования. Предположение о том, что образовательные возможности даже в рамках одного города могут существенно различаться по территориальному признаку, подтверждает исследование инфраструктуры дополнительного образования Центрального, Можайского и Рязанского районов Москвы, проведённое сотрудниками Института образования НИУ ВШЭ¹. Очевидным образом центральные районы предоставляют более широкие возможности для записи в кружки, секции или на дополнительные курсы. Одна из самых частых причин, по которой ребёнок не посещает желаемые дополнительные занятия: «Неудобно и (или) далеко ездить» (24 и 32\% соответственно среди живущих и в центре, и не в центре указывают на эту проблему).

По мнению экспертов, дополнительное образование является существенным фактором культурной депривации для малообеспеченных и маргинализированных слоёв населения. Возможно ли использование общественных ресурсов для того, чтобы поддержать доступ малоимущих слоёв к качественному дополнительному образованию? Если да, то какие механизмы наиболее эффективны? Краеугольным камнем этого вопроса становится непрозрачность финансирования учреждений, дающих дополнительное образование. Каждый из субъектов РФ может оказывать финансовую поддержку развитию учреждений дошкольного и дополнительного обучения, однако бюджетные средства не имеют чёткого адресного механизма. Средства поступают в регионы по механизму общих дотаций, и органы местного управления вольны сами решать, куда их направить - на образование или, к примеру, на денежные льготы населению. Возможное решение данной проблемы - создание механизмов адресной помощи, вроде квоты на бесплатные места для детей из малообеспеченных семей.

Ещё две черты неформального образования в России — это отсутствие чётких регламентов и учебных планов. Программы неформального образования с трудом поддаются классификации по роду занятий: это и инженерно-конструкторские кружки, и курсы плетения из бисера. С этим связаны трудности оценки эффективности занятий. Какие навыки необходимо оценивать? В ряде случаев дополнительное образование - это прибавочная часть к «официальной» школьной программе, и направлено оно на получение углублённых знаний по предметным дисциплинам. Однако есть и занятия творческого характера, задачей которых является развитие абстрактных когнитивных и коммуникативных навыков. В связи с этим разделением возникает вопрос: нужно ли дополнительное образование для улучшения образовательных достижений, или его цель состоит в формировании более широкого спектра когнитивных навыков (life skills)? В этом контексте примечательно, что из опрошенных первокурсников НИУ ВШЭ 3-10\% респондентов заявляют, что навыки высокого порядка (умение работать в команде, организованность, проектная работа) они приобрели не в семье или школе, а в кружках дополнительного образования. По мнению профессора Ричарда Мюрнейна, данные об эффективности навыков, приобретаемых в рамках дополнительного образования, можно получить только на основе

1 Более подробная информация о проекте доступна на сайте Института образования НИУ BШЭ (cм. URL: https://ioe.hse. $\mathrm{ru} / \mathrm{modernchildhood/projects).}$ 
лонгитюдных исследований, позволяющих отследить долгосрочную динамику изменения социальноэкономического статуса учащегося.

\section{Исследовательские перспективы}

Исходя из содержания докладов и дискуссий, проблема воспроизводства социального неравенства через образовательные институты характерна не только для России, но и для наиболее экономически развитых стран Запада. Возникает справедливый вопрос: существуют ли образовательные системы, приближенные к идеалам равенства? Обращаясь к недавнему прошлому, можно вспомнить массовое образование в Советском Союзе (чьи черты, безусловно, наследует и российская реальность), где обеспечение равного доступа к знаниям - от ликвидации безграмотности до массового производства инженеров-специалистов после Второй мировой войны - было определено идеологически. Однако, как отметил Д. Константиновский, говорить о всеобщем равенстве в Советском Союзе было бы сильным преувеличением - всегда были те, кто «равнее». Так, в эпоху «оттепели» 1960-х гг. уже существовали школы с углублённым изучением ряда дисциплин - языковые и экспериментальные физикоматематические спецшколы, которые давали более высокий уровень подготовки, а также становились местом «воспроизводства» интеллигенции в крупных городах. Это обращает нас к проблеме самого понятия «равенство». По мнению участников круглого стола, вместо того чтобы идти «вглубь», нам иногда стоит обратиться к моментам, которые вроде бы лежат на поверхности. Один из самых интересных вопросов круглого стола оказался сугубо понятийным: что мы имеем в виду, когда говорим о равенстве и неравенстве в образовании? Экскурс в историю и философию образования показывает, что само понятие «равенство» является нормативным и политизированным. Несмотря на прикладной характер исследований, представленных на Апрельской конференции, подобная постановка вопроса сделала очевидной необходимость и сугубо теоретических, историко-философских изысканий.

Помимо этого, можно выделить по крайней мере три магистральных вектора для дальнейших исследований образования. Первый: масштабные сравнительные исследования, направленные на выявление общих трендов, подобных тем, что были представлены в докладах американских коллег. Источники данных для этих исследований - мониторинги, подобные упомянутой выше Международной программе по оценке образовательных достижений учащихся (Programme for International Student Assessment, PISA), а также лонгитюдные и выборочные панельные исследования, организованные в разных странах. По мнению Ричарда Мюрнейна, есть ещё один вопрос, который, с нашей позиции, образует второй магистральный вектор и ответ на который могут дать только «длинные» данные: как соотносятся между собой академические достижения (academic achievements) и когнитивные навыки (life skills) в более широком смысле? Какой из этих факторов играет бо́льшую роль для жизненных шансов учащихся?

По мнению Д. Константиновского, несмотря на масштабность выводов, региональные факторы зачастую оказываются важнее общих характеристик, поэтому не стоит забывать об особенностях истории развития постсоветских образовательных систем. В первую очередь внимание следует уделять третьим факторам, влияющим на исследуемые явления, то есть ценностным ориентациям обучающейся молодёжи. Ценностные установки относительно образования, по мнению Константиновского, следуют за рыночной конъюнктурой: меняются критерии, определяющие социальный статус, а вмести с ними престиж разных родов деятельности. К примеру, предпринимательство (или, на языке советской эпохи, коммерция) очевидным образом превратилось из полулегальной деятельности в престижную, желанную работу для многих, что привело к повышенному спросу на экономическое и управленческое образование. В то же время некогда статусная работа инженера потеряла свои позиции из-за падения промышленной активности и сокращения рабочих мест. Ориентации учащейся молодёжи становятся ответом на трансформацию рынка труда, и это также связано с ценностными установками - возрас- 
танием личной ответственности за собственную образовательную и дальнейшую профессиональную траекторию.

Третий магистральный вектор непосредственно направлен на образование в России. По мнению руководителя Центра по исследованию инноваций в образовании Александра Сидоркина, при достаточном массиве данных мониторингов экономики образования и всероссийских опросов российской социологии образования не хватает качественной «школьной этнографии». Как взаимодействуют семьи с образовательными институтами? Как ощущается неравенство на субъективном уровне учащихся среднестатистической российской школы? Влияет ли социально-экономический статус учащегося на отношение преподавателей? Ответы на эти вопросы сложно получить с помощью массового анкетирования.

Не стоит забывать о существовании так называемого регионального компонента, который подразумевает, помимо базовых предметов, вариативные части учебного плана. Доля вариативной части составляет около $30 \%$, и наполнение её может быть абсолютно разным - от истории региона до национальных языков. С вариативным наполнением учебных программ также связан вопрос о том, как функционируют национальные школы, основной аудиторией которых являются представители других национальностей. Способствуют ли они интеграции или, наоборот, «замыканию» внутри общин?

Подводя итоги конференции, стоит отметить, что представления об образовании как о бесперебойно работающем инструменте социальной мобильности являются, скорее, утопическими. На функционирование образовательной системы влияет большое количество факторов - от способов её финансирования до ценностных ориентаций населения. Из докладов участников и прошедших дискуссий становится понятным, что образование - от дошкольного этапа и вплоть до получения университетского диплома - может быть источником социальной сегрегации. Стоит также отметить, что экономические эффекты от образования наиболее точно фиксируются лишь в долгосрочной динамике. В вопросах преодоления неравенства наиболее действенной оказывается направленная социальная политика, то есть та, которая учитывает особенности различных групп населения. Ключевым моментом является обеспечение доступа к образовательным возможностям учащихся с социально-экономическим статусом ниже среднего.

\section{Литература}

Carnoy M. et al. 2012. The Economic Returns to Higher Education in the BRIC Countries and their Implications for Higher Education Expansion. Basic Research Program. Working Papers. Series: Education. WP BRP 02/ EDU. Moscow: HSE. URL: https://www.hse.ru/pubs/share/direct/document/59041919

Duncan G. J., Murnane R. J. 2013. Restoring Opportunity: The Crisis of Inequality and the Challenge for American Education. Cambridge, MA; New York, NY: Harvard Education Press. 


\section{Tamara Kusimova}

\section{Education and Social Inequality}

\section{April International Academic Conference on Economic and Social Development, April 19-22, 2016. Moscow, Russia}

KUSIMOVA, Tamara - BA

Student, Faculty of Social

Sciences; Research Assistant, Laboratory for Studies in Economic Sociology, NationalResearch University Higher School of Economics. Address: 20 Myasnitskaya str., Moscow, 101000, Russian Federation.

\section{Email:tkusimova@yandex.ru} the effects of educational opportunities, social policy, studies of informal education, and further research.

The keynote speakers of the section were C. Aedo (World Bank), D. Alexandrov (HSE), A. Asmolov (FIRO), P. Bianchi (University of Ferrara), M. Carnoy (Stanford University), M. Feuer (The George Washington University), I. Froumin (HSE), L. Gortazar (World Bank), M. Jackson (Stanford University), N. Karmaeva (HSE), D. Konstantinovskiy (Institute of Sociology of the Russian Academy of Sciences), S. Kosaretsky (HSE), B. Kupriyanov (HSE), H. Levin (Columbia University), R. Murnane (Harvard Graduate School of Education), E. Pavlenko (HSE), A. Sidorkin (HSE), D. Semenov (HSE), V. Sobkin (Russian Academy of Education), K. Szafraniec (Nicolaus Copernicus University), A. Zakharov (HSE).

Keywords: education; inequality; school; university; comparative research; social mobility; social stratification.

\section{References}

Carnoy M., Loyalka P., Androushchak G., Proudnikova A. (2012) The Economic Returns to Higher Education in the BRIC Countries and their Implications for Higher Education Expansion. Basic Research Program. Working Papers. Series: Education. WP BRP 02/EDU, Moscow: HSE. Available at: https://www.hse.ru/ pubs/share/direct/document/59041919 (accessed 18 May 2016).

Duncan G. J., Murnane R. J. (2013) Restoring Opportunity: The Crisis of Inequality and the Challenge for American Education, Cambridge, MA; New York, NY: Harvard Education Press.

Received: May 11, 2016.

Citation: Kusimova T. (2016) Obrazovanie i sotsial'noe neravenstvo. XVII Aprel'skaya mezhdunarodnaya nauchnaya konferentsiya po problemam razvitiya ekonomiki i obshchestva, 19-22 aprelya 2016 g., Moskva, Rossiya [Education and Social Inequality. XVII April International Academic Conference on Economic and Social Development, April 19-22, 2016. Moscow, Russia]. Journal of Economic Sociology = Ekonomicheskaya sotsiologiya, vol. 17, no 3, pp. 142-150. Available at: https:/ecsoc.hse.ru/2016-17-3.html (in Russian). 


\section{Т. Ю. Ларкина}

\section{Вопросы истории и методологии экономической науки}

\section{XVII Апрельская Международная научная конференция по проблемам развития экономики и общества, 19-22 апреля 2016 г., Москва, Россия}

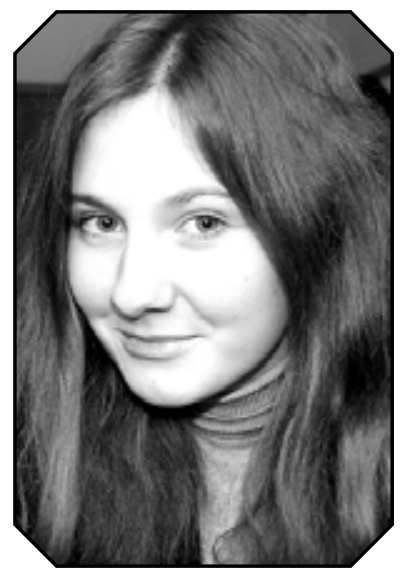

ЛАРКИНА Татьяна

Юрьевна - студентка бакалаврской программы «Социология» факультета социальных наук, стажёр-исследователь Лаборатории экономикосоциологических исследований Национального исследовательского университета «Высшая школа экономики». Адрес: 101000, Россия, г. Москва, ул. Мясницкая, д. 20.

Email: tlarkina@hse.ru
В рамках XVII Апрельской международной научной конференции по проблемам развития экономики и общества 20 и 21 апреля 2016 г. состоялась секция «Методология экономической науки» под руководством профессора НИУ ВШЭ Владимира Автономова. Секция включала пять сессий: «Как начиналась и продолжалась экономическая наука»; "Советские теоретики и историки мысли»; "Собственность, неравенство, патернализм»; «Методологические проблемь экономической науки»; «B поисках реалистичной экономической науки». На сессиях были представлены по три доклада, каждый из которых сопровождался дискуссией. Участниками секции стали сотрудники отечественных и зарубежнных университетов, в том числе из Польши и Франции. Предметом внимания докладчиков явились вопросы теоретико-методологического характера экономической науки и её истории, а также проблемы практического применения теоретического знания. В данном репортаже акиент делается на философско-методологической рефлексии экономики и истории экономических учений, отмечены проблемы и способы практического использования экономического знания, поэтому упомянуты не все выступления. Экономика - это неосуществившийся естественнонаучный проект, исконные основания которого являются моральными и связаны с философскими представлениями об организации хозяйственной жизни. С течением времени претерпевало изменения осмысление учёными экономической науки, её методологии и моделей человека экономического (hoто есопотісиs). Обращение экономистов, историков и методологов экономической мысли к философским теориям и концепџиям позволяет критически посмотреть на происходящее внутри дисциплинарной области, разрешить старые задачи и задать новые вопросы.

Ключевые слова: экономика; история экономических учений; методология экономической науки; homo economicus; прагматизм; философскометодологическая рефлексия.

Во время работы XVII Апрельской международной научной конференции по проблемам развития экономики и общества 20 и 21 апреля 2016 г. состоялась секция «Методология экономической науки», руководителем которой был профессор НИУ ВШЭ Владимир Автономов. Участниками секции стали сотрудники Национального исследовательского университета «Высшая школа экономики», Московского государственного университета, Российского экономического университета имени Г. В. Плеханова, СанктПетербургского государственного университета, Института экономики РАН, Уральского государственного экономического университета, Университета 
Пикардии им. Жюля Верна, Санкт-Петербургского государственного экономического университета и других зарубежных университетов. Секция включала пять сессий: (1) «Как начиналась и продолжалась экономическая наука» (докладчики О. Ананьин, В. Широнин, П. Клюкин); (2) «Советские теоретики и историки мысли» (докладчики Д. Мельник, Н. Неновски, Г. Гловели, А. Мальцев); (3) «Собственность, неравенство, патернализм» (докладчики Л. Тутов, Е. Устюжанина, А. Рубинштейн); (4) «Методологические проблемы экономической науки» (докладчики Д. Расков, И. Чаплыгина, Г. Мусиал); (5) «В поисках реалистичной экономической науки» (докладчики В. Автономов, Ж. Кампаньоло, В. Ефимов). Предметом внимания в докладах стали вопросы теоретико-методологического характера экономической науки и истории экономической мысли, а также проблемы практического применения теоретического знания. В данном репортаже акцент смещён на философско-методологическую рефлексию экономики и историю экономических учений; также отмечаются проблемы и способы практического использования экономического знания, поэтому упомянуты не все выступления. С аннотациями докладов и некоторыми полными версиями работ можно ознакомиться на странице секции (https://conf. hse.ru/2016/program).

\section{«Комплекс экономиста»}

Одной из примечательных черт докладов, представленных на секции «Методология экономической науки», является внимание учёных к исследовательским методам философии и интерес к этой дисциплине. Такая потребность возникает, когда необходимо осуществить анализ истории экономической мысли и подвергнуть её методологию рефлексии. Например, в выступлении О. Ананьина прозвучала мысль о том, что экономика, конкретно - модель саморегулируемого рынка, зарождалась как морально-философский проект, что важно понимать в контексте вопроса, заданного Томасом Гоббсом. По Гоббсу, общественный порядок не может существовать без государства-левиафана, укрощающего недобрую волю людей и вносящего рациональное зерно в их поведение [Гоббс 1991]. Представление о «невидимой руке», ещё неотчётливо сформулированное на страницах работы Адама Смита [Смит 1962], предполагает ортогональное решение гоббсовской проблемы: для установления общественного порядка не требуется надзор со стороны государства, рыночные силы способны привести систему к равновесию. Вместе с тем эпоха Просвещения с культурной доминантой веры в разум и интеллектуальный прогресс задаёт естественнонаучный императив экономике и её методологии. И, по мнению одного из участников обсуждения, экономисты оказываются в уязвимом положении, потому что, с одной стороны, они вышли из подполья философии и до сих пор окончательно не утратили морального основания собственной дисциплины, а с другой - им не удалось в полной мере реализовать проект «экономика» по образу и подобию естественных наук.

Экономисты, историки и методологи экономической науки обращаются к другим дисциплинам за исследовательской оптикой, средствами, необходимыми для устранения противоречий внутри собственной области знания и для поиска решений прикладных задач. В докладе «Рональд Коуз о методологии экономической науки» Д. Расков демонстрирует пример небезызвестного учёного, который благополучно выходит за дисциплинарные границы экономики, чтобы ответить на вопросы в её пределах. Фигура лауреата Нобелевской премии по экономике Рональда Коуза - выдающаяся среди ортодоксальных экономистов. Владение методологическими инструментами философии позволяет Коузу независимым и критическим взглядом посмотреть на то, что происходит в поле экономической науки. Коуз придерживается позиции, что экономические методы неуместны для анализа неэкономических явлений, а при изучении экономических явлений необходимо учитывать сложность институциональной среды. 


\section{Усложнить нельзя умножить}

Модель человека в экономической науке, или, другими словами, представления о человеческой природе экономтеоретиками, претерпевала изменения во времени. Как и любая другая, данная модель упрощённый и в той или иной степени абстрактный макет, задача которого заключается в том, чтобы уловить происходящие в реальном мире явления и объяснить их. Однако окружающая нас реальность отличается многообразием и комплексностью, строгая аналитическая модель homo economicus не способна истолковать поведение человека, не допустив ряд осечек, порой непростительных, за что экономисты и подвергаются критике с разных сторон. В. Автономов показывает в докладе, что из данной запутанной ситуации есть как минимум два выхода: (1) усложнить модель экономического человека, предписывая ему всё новые и новые свойства, как это делал Людвиг фон Мизес [Мизес 2005], или (2) создавать другие модели человека в экономической науке вслед за Йозефом Шумпетером, выделявшим несколько типов предпринимателей [Schumpeter 1934].

Следование первому пути таит в себе опасность потерять человека в экономической теории как рационально действующего агента, тем самым поручить определение человеческой природы другим научным дисциплинам. Второй путь не предполагает отказа от канонической для экономистов модели человека, которая небезрезультатно работает в определённых случаях или контекстах; однако решение заключается в создании другой модели человека, позволяющей объяснить аномалии, не вписывавшиеся ранее в рамки экономической теории.

Для достижения исследовательских целей учёный может не только намеренно увеличивать число моделей человека в экономической науке, но и предлагать несколько способов конструирования истории экономической мысли. Так, П. Клюкин познакомил слушателей доклада с новаторским подходом к анализу развития и распространения интеллектуальной традиции исследования хозяйственного кругооборота, существующей уже более 250 лет. Автор доклада использовал концепцию «порогов» Мишеля Фуко, предложенную французским мыслителем в работе «Археология знания» [Фуко 2004], и выделил несколько цепочек идей в традиции хозяйственного кругооборота, что образует аналитическую оптику, которая делает возможным рассмотрение проблем онтогенеза традиции исследования кругооборота хозяйственной жизни и объяснение причины её «стагнации».

\section{Теоретики и практики}

Похоже, что вопросы «как преподавать историю экономических учений?», «почему студентыэкономисты не любят историю экономических учений?» вызвали наибольший интерес у присутствующих на секции, о чём может свидетельствовать оживлённая дискуссия после выступления А. Мальцева. Докладчик отметил, что университетский предмет «История экономических учений» имел нелёгкую судьбу в конце XX и начале XXI века ввиду того, что предмет не вызывал интереса у слушателей и не представлялся ценным для них. Но история экономической мысли, рассмотренная уже вне отрыва от социального контекста и интеллектуального климата эпохи, в которую экономическая мысль зарождалась, обернулась успешным «продуктом» для студентов экономических факультетов. С точки зрения такого подхода, «новая» история экономических учений, или, как называет её докладчик, историография экономической науки, фокусируется на контекстуальных деталях и подробно повествует о том, как формировались идеи экономических теорий. Однако важно понимать, что при увлечении фоновыми деталями и доскональным описанием возникновения одной теории появляется вероятность того, что ускользнёт содержательная часть изучаемой концепции и невозможно будет представить цельную картину истории экономической мысли в её преемственности или связанности. Преподавателям истории экономических учений поэтому нужно найти баланс между старыми (акцент на содержании экономических концепций) и новыми подходами к её анализу, а также равновесие в представлении её аудитории. 
Также участники секции в некоторой степени касались проблем прикладного характера, как, например, в своих докладах А. Рубинштейн, В. Автономов и В. Ефимов, Ж. Кампаньоло, Е. Устюжанина, Л. Тутов. В. Ефимов, представивший совместный проект с В. Автономовым, условно обозначил два канона, существующих в экономике. Первый восходит к картезианству с его ориентацией на естественнонаучный идеал. Суть этого подхода заключается в стремлении достичь универсальных, внеисторических истин. Второй основывается на прагматизме, для него важны неразрывная связь знания с опытом и интеллектуальный поиск (intelligence), который соединяет привычное и новое. Эти два канона тесным образом соотносятся с двумя типами либерализма - с экономическим (фритредерство) и политическим (политическая свобода) соответственно.

Согласно Джону Дьюи, одному из основателей прагматического течения в философии, неотъемлемым атрибутом человека выступают привычки, которые он приобретает в процессе социализации [Дьюи 2001]. Привычки с трудом поддаются изменению, именно поэтому при столкновении с необычным фактом человек пытается увязать его со своим прошлым опытом и имеющимися знаниями [Автономов 1998; Дьюи 2001]. Философия Дьюи вносит ясность в дебаты о том, как необходимо реализовывать политические реформы и проводить институциональные изменения. Не следует резко и революционно осуществлять политические мероприятия ввиду озвученной выше особенности человека - его приверженности привычному поведению; выработка наиболее оптимальных для населения политических решений возможна в процессе общественной дискуссии.

Доклады, представленные на секции «Методология экономической науки», обладают эвристическим потенциалом, который может быть востребован у экономсоциологов. Выход за пределы собственной дисциплинарной области способен предложить социальному учёному новые точки обзора исследовательской проблемы, критически оценить проделанную работу и подвергнуть её методологической рефлексии. Это ведёт к улучшению качества исследования и обнаружению нестандартных решений для стандартных задач.

\section{Литература}

Автономов В. С. 1998. Модель человека в экономической науке. СПб.: Экономическая школа.

Гоббс Т. 1991. Левиафан, или Материя, форма и власть государства церковного и гражданского. В изд.: Гоббс Т. Сочинения: В 2 m. Т. 2. М.: Мысль.

Дьюи Дж. 2001. Реконструкция в философии. Пер. с англ. М. Занадворова, М. Шикова. М.: Логос.

Мизес Л. 2005. Человеческая деятельность. Трактат по экономической теории. Пер. А. В. Куряева. Челябинск: Социум.

Смит А. 1962. Исследование о природе и причинах богатства народов. М.: Соцэкгиз.

Фуко М. 2004. Археология знания. Пер. М. Б. Ракова. СПб.: ИЦ «Гуманитарная академия»; Университетская книга.

Schumpeter J. A. 1934. The Theory of Economic Development. Cambridge, Mass: Harvard University Press. 


\section{Tatyana Larkina}

\section{The Questions of Economics History and Methodology}

\section{April International Academic Conference on Economic and Social Development, 19-22 April 2016, Moscow, Russia}

\begin{abstract}
LARKINA, Tatyana - BA
Student, Faculty of Social

Sciences; Research Assistant, Laboratory for Studies in

Economic Sociology, National

Research University Higher

School of Economics. Address:

20 Myasnitskaya str., Moscow,

101000, Russian Federation.
\end{abstract}

Email: tlarkina@hse.ru

\begin{abstract}
The "Economic Methodology" section under the moderation of HSE Professor Vladimir Avtonomov took place on the 20th and 21st of April within the XVII April International Academic Conference on Economic and Social Development. The section consisted of five sessions: "Economics: Beginning and Continuation"; "Soviet Theorists and Historians of Thought"; "Property, Inequality, Paternalism"; "Methodological Problems of Economic Science"; and "In Search of a Realistic Economics." Each session had three reports which were followed with discussion among the participants. The question of theoretical and methodological nature of economics and history of economic thought as well as the prob-
\end{abstract}

This paper focuses on a philosophical and methodological reflection of economics and the history of economic thought, and it partly stresses the problems and practical application of economic knowledge; therefore, not all reports are discussed. Economics is an unrealized natural science project in which primordial foundation has a moral character and is associated with philosophical notions about economy life organization. Scholars' comprehension of economics, its methodology, and models of economic human has changed over the years. Economists, historians, and methodologists of economic thought reference the philosophical theories and concepts, which allow them to look critically at what is happening inside the disciplinary area, resolve old problems, and ask new questions.

Keywords: economics; history of economic thought; economic methodology; homo economicus; pragmatism; philosophical and methodological reflection.

\section{References}

Avtonomov V. S. (1998) Model'cheloveka v ekonomicheskoy nauke [A Model of the Human in Economics], Saint Petersburg: Ekonomicheskaya shkola (in Russian).

Dewy J. (2001) Rekonstruktsiya v filosofii [Reconstruction of Philosophy] (trans. M. Zanadvorova, M. Shikova), Moscow: Logos (in Russian).

Foucault M. (2004) Arkheologiya znaniya [The Archaeology of Knowledge] (trans. M. B. Rakova), Saint Petersburg: IC “Gumanitarnaya Akademiya'; Universitetskaya kniga (in Russian).

Hobbes T. (1991). Leviafan, ili Materiya, forma i vlast' gosudarstva tserkovnogo i grazhdanskogo [Leviathan, or the Matter, Forme, and Power of a Commonwealth, Ecclesiasticall and Civil]. Selected Works: 2 vols. Vol. 2, Moscow: Mysl (in Russian). 
Mises L. (2005) Chelovecheskaya deyatelnost: Traktat po ekonomicheskoy teorii [Human Action: A Treatise on Economics] (trans. by A. V. Kuryayev), Chelyabinsk: Sotsium (in Russian).

Schumpeter J. A. (1934) The Theory of Economic Development, Cambridge, Mass: Harvard University Press.

Smith A. (1962) Issledovanie o prirode i prichinakh bogatstva narodov [An Inquiry into the Nature and Causes of the Wealth of Nations], Moscow: Sotsekgiz (in Russian).

Received: April 24, 2016.

Citation: Larkina T. (2016) Voprosy istorii i metodologii ekonomicheskoy nauki. XVII Aprel'skaya mezhdunarodnaya nauchnaya konferentsiya po problemam razvitiya ekonomiki i obshchestva, 19-21 aprelya $2016 \mathrm{~g}$., Moskva, Rossiya [The Questions of Economics History and Methodology. XVII April International Academic Conference on Economic and Social Development, April 19-22, 2016. Moscow, Russia]. Journal of Economic Sociology = Ekonomicheskaya sotsiologiya, vol. 17, no 3, pp. 151-156. Available at: https://ecsoc.hse. $\mathrm{ru} / 2016-17-3 . h t m l$ (in Russian). 


\section{INTERVIEWS}

\section{Digital Labor and the Sharing Economy: An Interview with Ivana Pais}

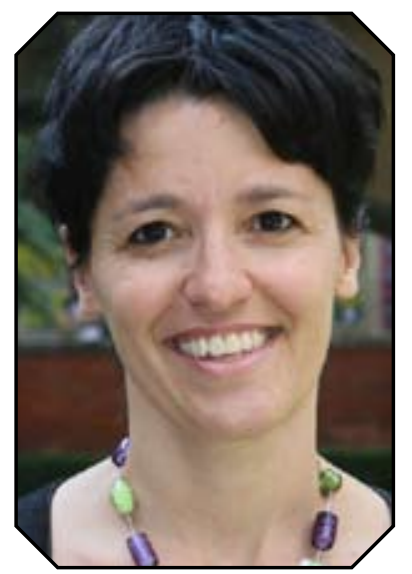

PAIS, Ivana - Associate Professor of Economic Sociology, Department of Sociology, Università Cattolica del Sacro Cuore. Address: 1 Largo A. Gemelli, Milano, 20123, Italy.

Email: ivana.pais@ unicatt.it

\begin{abstract}
Prof. Ivana Pais was interviewed by Ivan Pavlyutkin, associate professor at the National Research University Higher School of Economics. The conversation occurred at the Department of Sociology of Catholic University of the Sacred Heart in Milan. Pais introduces us to her career path as an economic sociologist, and explains challenges that economic sociologists encounter while teaching economics students and why it is more insightful than teaching sociology students. She also talks about directions and peculiarities of economic sociological thought in Italy. There is a strong tradition in Italy to study industrial districts with their network of small firms and labor markets.
\end{abstract}

In the interview, Pais shares her previous and current research projects. She points out the significance of the digital economy for a better understanding of some market processes happening within the local community and describes her current research concerning the sharing economy. Applying Karl Polany's theoretical perspective, she argues that the Italian sharing economy is embedded in noneconomic institutions. A pure digital sharing economy model that lacks social interactions (the Silicon Valley type) does not work in Italy.

Finally, Pais provides information about her participation in the conference arranged by the European commission and the organization of future mini-conference in Berkley.

Keywords: digital economy; sharing economy; local community; economic sociology; social embeddedness; peer-to-peer economy.

- My first questions are about your career and academic path. How did it happen that you are now working as an economic sociologist?

- I started with my thesis, my degree thesis in the sociology of work, about the French model of "Bilan de Competence," an interesting opportunity to reflect on the mobility of professional careers, the individualization of work and the transformation of labor policies. Then, my professor, Silvia Cortellazzi, asked me to work with her on research about the relationship between training and work. I then did my PhD here, at Università Cattolica.

- What was the topic of your PhD thesis?

- It was about the new economy, so I started to study the digital economy in 1999. And my idea as a $\mathrm{PhD}$ student was to study the new economy not strictly because of the digital aspect but because, through the "dot-com bubble," we 
were experiencing a new form of organization and labor relations. That sector was the one in which you could see things changing, and the main research question of my $\mathrm{PhD}$ study thesis aimed at understanding if that sector could lead transformation even through other sectors. The social transformation was so fast that I started to study the dot-com period when it was at its best and was changing the culture of organization. But then there was the dot-com bubble. Everything changed, and it was far more interesting to understand how the failure was managed.

Then, I won a public competition, and I began working as an economic sociologist researcher at the University of Brescia. Brescia is a very industrial city, and my focus shifted more to industrial relations and trade unions, of which there is a strong tradition.

Also, because of the period from the speculative bubble until the 2000s, the digital economy has had little relevance in Italy. I resumed my studies on these issues with the spread of social networks, but the most interesting impact has to do with the so-called sharing economy or economy platforms that have begun to mediate goods and services, not just information.

- We are talking about economic sociology in Italy, so can you give some examples of scholars working in Italy who now are well recognized in economic sociology?

- There is a strong tradition in Italy of the study of the industrial district and the role of community and the local internal economy, in particular in some areas where there are networks of small firms that work together and complement each other in terms of education and "local collective competition goods." Even while studying digital economy, you need to understand local economy. One of the prominent scholars in this field is Carlo Trigilia, who served as the minister for territorial cohesion. Related to this field, there are some studies in regulation models, such as those led by Marino Regini.

Another main topic is the labor market and various kinds of transformation. One leading scholar in this field is Emilio Reyneri. Today, this field is more about immigrants and young people, while, in the past, there was a focus on gender. Gender studies are also widespread in organization studies. The research of Silvia Gherardi is interesting, even because of the methodology she adopted: she uses grounded theory and qualitative methods, while, usually, labor markets are more strictly studied with the help of quantitative methods and longitudinal data.

Furthermore, we have a strong tradition of studies of industrial relations, in particular on trade unions, such as those conducted by Gian Primo Cella.

Finally, a significant figure for Italian sociology was Luciano Gallino, who died a few months ago and who, by the way, also worked on globalization and inequality.

- When I came to Italy, I noticed that sociologists here often use in discussions such terms as local, community, social capital, networks, gift economy and sharing economy. Can we say that these concepts represent the tradition of Italian economic sociology? Do they serve as a distinction between US economic sociology and European studies?

- It is like that. And I think that it is related to our society and our economics. You need the right lens to analyze what you are studying. And, if you are a good researcher, I think you change your lens in order to use a more appropriate one to understand the economic context you are working on. For example, you can't study the digital economy in Italy and Silicon Valley using the same approach. So, in order to understand the society and economics in Italy, the local is really important because this is one of the meanings of embeddedness. 


\section{— So, you find here embeddedness in a pure form?}

— Societies rarely manifest phenomena in pure form, but, certainly, the study of embeddedness in the Italian economy is particularly interesting.

- I have several questions about teaching. I saw your students from the economic department. Do you think there is a difference between teaching economic sociology to economists and to sociologists?

- Yeah, completely. I prefer teaching economic students because, when they understand sociology, it can change the way they analyze phenomena. I give them different tools in order to understand the same topics they used to analyze through other categories. If they learn and appreciate it, that can really change the way they will do their job. While, as an economic sociologist dealing with sociology students, you don't change the way they think and they already manage the same analytical categories, you help them to apply those categories to a specific field.

- So, if you don't need arguments for sociologists, do you need them for economists?

- Yes, but I enjoy it because, sometimes, you have tough debates with economic students, and it's more productive. While, with sociology students, they often agree with you and your approach, ... with economic students, sometimes they argue, and you deliver the best lesson when students argue because you need to support your approach and demonstrate how good and useful it can be for them. So I prefer this kind of lesson.

\section{- What do you usually discuss with students?}

- It's more about the approach, about what you are looking at when you study some phenomena. For example, together with a colleague, I had a lesson with my students about methodology. We made an exercise, and we asked them to identify indicators of happiness. And their first reaction was: "Why should I need to measure happiness? I don't care." So we tried to explain, for example, the economics of happiness. And, during the exercise, at first they were only looking at economic indicators of happiness. And then, when we told them, "Ok, there are other indicators," they could not see them at first. Then, if you work with them, some of them really start to look at the same phenomena with a different approach, and it is really rich.

- Can you list some papers or books that you appreciated or books that really influenced your vision of economic sociology?

- Italian?

— Not only Italian, but maybe in a broader sense. What are the main books for you?

- Karl Polanyi, for sure.

— The Great Transformation [Polanyi 1944] you mean?

- Yeah. The Great Transformation by Polanyi was one of the most influential works for me. And Manuel Castells' books on the information society [Castells 1996]. But Polanyi is more about the approach; Castells is more about the topic. So it was a good analysis because of that. Granovetter because of the idea of embeddedness and the role of social networks, the strength of weak ties...[Granovetter 1973; 1985], but also — in this field — Nan Lin and Ronald Burt. In my training, it was also important. The New Spirit of Capitalism by Boltanski and Chiapello [Boltanski, Chiapello 2005]. 
- What about some contemporary books in economic sociology? You also mentioned David Graeber [Graeber 2014].

- Yeah, David Graeber is rather an anthropologist; I really appreciate that.

- Could you name some major works concerning the new economy or research about the sharing economy?

— For example, the article by Juliet Schor on the sharing economy [Schor, Fitzmaurice 2015] is important and influential. He is not a sociologist, but, for my studies, ... Yochai Benkler's works were also very important [Benkler 2006]. I even really appreciate the work of Ursula Huws about digital labor [Huws 2013]. But it's too early to judge how this research will change the way we look at some phenomena.

- Does it mean that, for what you are doing in research, there are not many books that were published and papers that are influential for the whole perspective?

- Yeah. This depends on the fact that they are recent studies and also on the new academic way of doing things. The new incentives lead scholars to publish more articles but fewer books, more specialized or focused papers and a less global theoretical approach. We have some great scholars on specific topics, who do a very good job on a specific topic, but they are not really changing the way we look at phenomena.

\section{- What are your explanations of this?}

- The simple fact that books are not appreciated anymore... writing a book is a different kind of job to writing a paper. You thus need a global approach and you have to explain it while writing papers; it's more technical stuff. It's useful because it can lead to a more incremental approach, but you often lose a global approach to social phenomena.

- I would like to discuss the new economy, sharing economy and all these issues of your main research area. Can you say a few words more broadly on what you are doing?

- Oh. I will focus on the sharing economy; that's easier. Digital labor and the sharing economy are related to each other. Yeah, it's a global scholarship community but with strong ties to the different national communities. What's interesting, I think, is that the debate about the sharing economy is open both to scholars and practitioners. The debate about the sharing economy is run jointly by scholars and consultants or people coming from movements or associations. And practitioners are inside the field but with a strong reflective practice. And they are much faster than academics. That is important in such a fast-changing environment. That's why they are leading the public debate more than academics. I mean, when you publish your paper, everything is changed, while people who have a blog can think, write and publish in real time. And so, I think they are leading the debate more than scholars because of that. That's why academics should not focus their research on day-to-day transformation, but we need to play our role in order to watch the main scheme...

- The whole picture...

- ...The whole picture. It's not very easy, and it's good to collaborate together with these consultants because they can follow the day-by-day life courses. But we need to distinguish our approach and give a different contribution that can last longer. So we need to produce knowledge that, even years later, can be useful. 


\section{— Ok, you mentioned that there is a debate about the sharing economy. When did it start in Europe?}

- The debate about the sharing economy emerged from the crisis of 2008. When the crisis began, we used to say that the Chinese ideogram for crisis means danger and opportunity at the same time. Then, we discovered that it is not true, but we liked the idea and we continued to tell this story. The years passed by, and we didn't find new opportunity. The crisis was there, but no one was really debating about the problem at the source of the crisis. No one was looking for solutions; we were waiting. At least in Italy, we were waiting, telling each other, "OK, it will finish. OK, it will finish and everything will be as it was," without really debating if we were happy about what was going on before the crisis. The sharing economy, at least in Italy - I'm not sure it's the same everywhere - captured people trying to find a different way to manage the economy. And it was a sort of collector of ideas and experience that was trying to figure out a different way to run the economy. So, the most important thing about the sharing economy was the raising of the idea of re-socializing the economy.

\section{- Who are the main intellectuals who now influence such kinds of ideas and notions of re-socialization?}

— They are mainly "grassroots intellectuals."

- What do you mean?

- They are not scholars in a strict sense. The idea of the sharing economy was introduced by a consultant, Rachal Botsman....and, now, it is shared by other consultants or intellectuals close to social movements, such as Michel Bauwens, but, in the sharing economy, it is going on exactly as was explained by Boltanski and Chiapello. The idea is that capitalism absorbs its critics and incorporates them in order to build a new form of capitalism and culture of capitalism. What is going on with the sharing economy is impressive as long as you can observe the economic development that occurs together with the grassroots and companies.

\section{- Can you give any examples of new initiatives from Italy?}

- Yes, for example, Sardex, ${ }^{1}$ initiated by some unemployed people. It's more like a grassroots initiative but an economic one. So, Sardex is really interesting because it stays inside the market dimension, but a re-socialized one, and uses the local currency in order to do it. When I was in Sardinia in order to do research about the sharing economy, I was impressed by the fact that, when speaking with people using Sardex, they spoke more about trust and reputation than about money.

\section{— Do you have any classification of the practices of the sharing economy?}

- There are some practices, some classifications that are really good, but there is not a commonly accepted one. The main distinction is about profit and nonprofit forms of the sharing economy. In Italy, we have had an interesting experience in the nonprofit field. For example, another really interesting initiative in Italy is the "social street." The idea was born a couple of years ago in Bologna, where some friends decided to open a closed Facebook group for all the residents of their street, via Fondazza. They opened this Facebook group, and then they put some ads on the street, saying "we are opening a Facebook group; if you live on via Fondazza, please, join us." People who did not know each other by being neighbors started to go to the Facebook group and interact through the group. When the Facebook group grew, then they started to meet each other in person and make some social and economic initiatives. And, now, there are a lot of streets all over Italy, and that's a really interesting phenomenon because the Italian sharing economy incorporates

1 Local currency used in Sardinia, which was introduced by a group of friends after the financial crisis of 2008. Available at: http://www.ft.com/cms/s/2/cf875d9a-5be6-11e5-a28b-50226830d644.html (accessed 20 May 2016). 
more mixed online-offline activities than the Silicon Valley model implies. While the Silicon Valley model is all about the digital, in Italy, the sharing economy works when it is more embedded into the local, and the digital and face-to-face aspects work together. Otherwise, it doesn't work. The pure digital sharing economy doesn't work.

\section{— Are there any theoretical debates on this issue?}

- It's starting. One topic these days is about platform "cooperativism." There was an interesting conference in New York last year. ${ }^{2}$ One of the main topics about the sharing economy is about how to redistribute value to the "peers" that generate it through the platforms.

The main scholars in this field are Trebor Scholz and Nathan Schneider, who organized that conference. They adopted a critical approach, and so they see the sharing economy as an extreme form of neoliberal capitalism, not as a re-socializing one, because the sharing economy uses social value in order to increase economic capital. And, for example, I did a map of the sharing economy initiative in Italy, and we mapped more than 200 platforms, and only two were cooperatives, while, in Italy, we have a strong tradition of cooperatives, but not in the digital economy sector.

Another topic concerns the regulation of the new economy because this peer-to-peer economy can damage the traditional economy as it changes the way we understand it and analyze its impact on the traditional economy. It's really important. Another huge topic is about labor in the digital economy because people sharing goods and services are neither employees nor employers.

\section{- Like freelancers?}

— Yes, it's a type of freelance work but with a really short-term job. It's micro freelance.

- This is a point, for example, economists, sociologists and anthropologists now have a debate about. How is it limited to some disciplinary boundaries, or would you say that the sharing economy has no disciplinary boundaries, for example...

- It has disciplinary boundaries, but economists are not looking so much at these phenomena. I had an academic debate with economists, and they told me it's because the sharing economy nowadays has no strong impact on our GDP.

\section{- Does anyone try to measure its impact?}

— No, because they say it's not ... so relevant. So, this colleague, for example, told me "until the sharing economy becomes huge, I won't consider it, it's not my business... It's more important for me to study the car industry because the car industry is leading the economy." Maybe they will change approach when (and if) car sharing and carpooling prevail. So, now, we have more sociologists, anthropologists and jurists and law scholars.

- Thank you!

Interviewed by Ivan Pavlyutkin Milan, Italy, 12 November 2015

2 Platform Cooperativism is convened by Trebor Scholz (The New School) and Nathan Schneider (University of Colorado Boulder). Available at: http://platformcoop.net/ (accessed 20 May 2016). 


\section{References}

Ambrosini M. (2001) The Role of Immigrants in the Italian Labour Market. International Migration, vol. 39, no 3, pp. 61-83.

Benkler Y. (2006) The Wealth of Networks: How Social Production Transforms Markets and Freedom, New Haven, CT: Yale University Press.

Boltanski L., Chiapello E. (2005) The New Spirit of Capitalism, London: Verso.

Botsman R., Rogers R. (2010) What's Mine is Yours. The Rise of Collaborative Consumption, New York: HarperCollins Publisher.

Bruni A., Gherardi S., Poggio B. (2004) Gender and Entrepreneurship: An Ethnographic Approach, London: Routledge.

Castells M. (1996) The Information Age: Economy, Society and Culture, 3 vols. Malden, MA; Oxford, UK: Blackwell.

Donati P. (2010) Relational Sociology: A New Paradigm for the Social Sciences, London: Routledge.

Gherardi S. (2009) Organizational Knowledge: The Texture of Workplace Learning, Malden, USA; Oxford, UK; Victoria, Australia: John Wiley and Sons.

Graeber D. (2014) Debt-Updated and Expanded: The First 5,000 Years, Brooklyn: Melville House.

Granovetter M. S. (1973) The Strength of Weak Ties. American Journal of Sociology, vol. 78, no 6, pp. 1360-1380.

Granovetter M. (1985) Economic Action and Social Structure: The Problem of Embeddedness. American Journal of Sociology, vol. 91, no 3, pp. 481-510.

Huws U. (2013) Working Online, Living Offline: Labour in the Internet Age. Work Organisation, Labour and Globalisation, vol. 7, no 1, pp. 1-11.

Lin N. (2002) Social Capital: A Theory of Social Structure and Action. Series "Structural Analysis in the Social Sciences" (ed. M. Granovetter), vol. 19, Cambridge, UK; New York, USA: Cambridge University Press.

Polanyi K. (1944). The Great Transformation: The Political and Economic Origins of Our Time, Boston, MA: Beacon Press.

Schor J. B., Fitzmaurice C. J. (2015). Collaborating and Connecting: The Emergence of the Sharing Economy. Handbook of Research on Sustainable Consumption (ed. L. A. Reisch, J. Thøgersen), Cheltenham, UK: Edward Elgar, pp. 410-425.

Received: November 11, 2015.

Citation: Digital Labor and the Sharing Economy: An Interview with Ivana Pais (2016) Journal of Economic Sociology = Ekonomicheskaya sotsiologiya, vol. 17, no 3, pp. 157-163. Available at: https://ecsoc.hse. $\mathrm{ru} / 2016-17-3 . h t m l$. 
Май 2016

Электронный журнал www.ecsoc.msses.ru www.ecsoc.hse.ru

ISSN 1726-3247

\section{Адрес редакции}

101000, Россия,

г. Москва,

ул. Мясницкая, д. 20, комн. 406 тел.: (495) 628-48-86 email: ecsoc@hse.ru

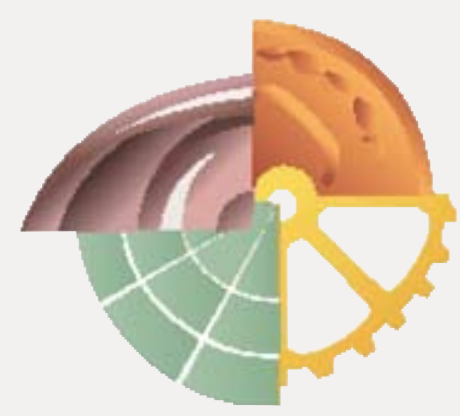

\section{Journal of}

Economic Sociology

Vol. 17. No 3.

May 2016

Electronic journal www.ecsoc.msses.ru www.ecsoc.hse.ru

ISSN 1726-3247

\section{Contacts}

20 Myasnitskaya street, room 406 101000 Moscow, Russian Federation phone: +7 (495) 628-48-86 email: ecsoc@hse.ru

\section{Доступ к журналу}

- Доступ ко всем номерам журнала — постоянный, свободный и бесплатный.

- Каждый номер содержится в едином файле (10-12 п. л. в PDF).

- Если хотите, чтобы Вас оповещали о выходе очередного номера, пожалуйста, заполните форму подписки: https:/www.hse.ru/expresspolls/ poll/23725626.html.

\section{Open Access Policy}

- All issues of the Journal of Economic Sociology are always open and free access

- Each entire issue is downloadable as a single PDF file

- If you wish to receive notification when new issues are published, please fill out the following form: https://www.hse.ru/expresspolls/poll/23725626.html 